\title{
Assessment of Geothermal Resource Potential at a High-Priority Area on the Utah Testing and Training Range-South (UTTR-S)
}

Richard P. Smith

Robert P. Breckenridge

Thomas R. Wood

April 2012

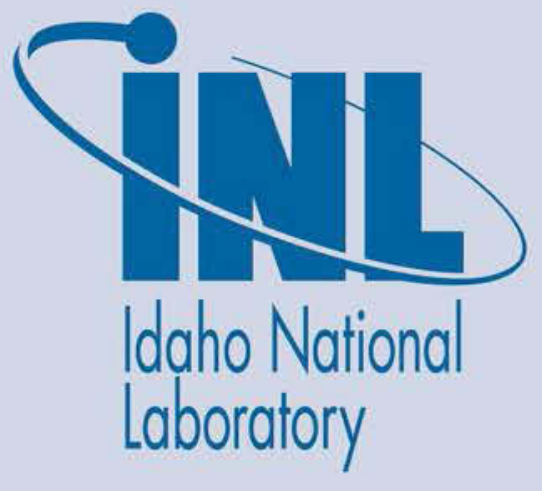

The INL is a U.S. Department of Energy National Laboratory operated by Battelle Energy Alliance 


\section{DISCLAIMER}

This information was prepared as an account of work sponsored by an agency of the U.S. government. Neither the U.S. government nor any agency thereof, nor any of their employees, makes any warranty, expressed or implied, or assumes any legal liability or responsibility for the accuracy, completeness, or usefulness, of any information, apparatus, product, or process disclosed, or represents that its use would not infringe privately owned rights. References herein to any specific commercial product, process, or service by trade name, trade mark, manufacturer, or otherwise, does not necessarily constitute or imply its endorsement, recommendation, or favoring by the U.S. government or any agency thereof. The views and opinions of authors expressed herein do not necessarily state or reflect those of the U.S. government or any agency thereof. 
INL/EXT-11-22215

Revision 1

\section{Assessment of Geothermal Resource Potential at a High-Priority Area on the Utah Testing and Training Range-South (UTTR-S)}

Richard P. Smith, Ph.D., PG

Robert P. Breckenridge, Ph.D. Thomas R. Wood, Ph.D., PG

April 2012

Idaho National Laboratory
Idaho Falls, Idaho 83415

http://www.inl.gov

Prepared for the

U.S. Department of Energy

Assistant Secretary for Energy Efficiency and Renewable Energy Under DOE Idaho Operations Office

Contract DE-AC07-05ID14517 



\section{ACKNOWLEDGEMENTS}

This report is the product of the joint efforts of Idaho National Laboratory (INL), and Smith Geologic and Photographic Services with input from the Utah Geological Survey (UGS), the Energy and Geoscience Institute (EGI), and the Department of Geology and Geophysics at the University of Utah. Specifically, the authors wish to thank Rick Allis of the UGS and Joe Moore of EGI for their advice and assistance throughout this project.

The authors also wish to acknowledge Robert Blackett, Mark Gwynn, and Andrew Rupke of the Utah Geological Survey; Dan Brinton, John McLennan, Joseph Moore, Clay Grant Jones, Beth Murphy, and Greg Nash of the Energy and Geoscience Institute; and Paul Gettings of the Department of Geology and Geophysics at the University of Utah for their assistance in preparing,

conducting, recording, and providing the invaluable information contained within the five appendixes of this report. Without their tireless efforts, the collection of the immeasurable data contained in this report would not have been possible. 


\section{EXECUTIVE SUMMARY}

Field investigations conducted during 2011 support and expand the conclusion of the Preliminary Report (Smith et al., 2011) that discovery of a viable geothermal system is possible in the northwestern part of the Utah Testing and Training Range-South (UTTR-S), referred to henceforth as Focus Area 1. The investigations defined the southward extent of the Wendover graben into and near Focus Area 1, enhanced the understanding of subsurface conditions, and focused further geothermal exploration efforts towards the northwestern-most part of Focus Area 1. Specifically, the detailed gravity survey shows that the Wendover graben, first defined by Cook et al. (1964) for areas north of Interstate Highway 80, extends and deepens southwest-ward to the northwest corner of Focus Area 1. At its deepest point, the intersection with a northwest-trending graben there is favorable for enhanced permeability associated with intersecting faults. Processing and modeling of the gravity data collected during 2011 provide a good understanding of graben depth and distribution of faults bounding the graben and has focused the interest area of the study.

Down-hole logging of temperatures in wells made available near the Intrepid, Inc., evaporation ponds, just north of Focus Area 1, provide a good understanding of the variability of thermal gradients in that area and corroborate the more extensive temperature data reported by Turk (1973) for the depth range of 300-500 m. Moderate temperature gradients in the northern part of the Intrepid area increase to much higher gradients and bottom-hole temperatures southeastward, towards graben-bounding faults, suggesting upwelling geothermal waters along those faults. Water sampling, analysis, and temperature measurements of Blue Lakes and Mosquito Willey's springs, on the western boundary of Focus Area 1, also show elevated temperatures along the grabenbounding fault system. In addition, water chemistry suggests origin of those waters in limestone rocks beneath the graben in areas with temperatures as high as $140^{\circ} \mathrm{C}\left(284^{\circ} \mathrm{F}\right)$.

Compilation and analysis of geophysical logs of petroleum exploration wells nearest Focus Area 1 exhibit low calculated porosities and permeabilities of unfractured basement rocks, but such calculations apply only to small volumes of rock near the boreholes. It is known from other studies that the rocks that make up the bedrock near Focus Area 1 host regional aquifers and thus may contribute to permeabilities required for geothermal systems. Multiple lines of evidence suggest that enhanced permeability along fault zones, in addition to inherent permeability of host rocks, must be sought out during future exploration efforts. In addition, the comparison of gamma logs of two petroleum exploration wells 
northeast of Focus Area 1 suggest a downward-to-the-west displacement along a graben-bounding fault, consistent with a sense of offset indicted by the gravity anomalies.

Lineaments are defined as linear features on the surface of the earth such as faults. An analysis of aerial photographic imagery reveals the presence of lineaments in locations and orientations consistent with locations of subsurface faults indicated by the gravity surveys. Field checks on some of the lineaments that extend into nearby bedrock areas show the presence of fractured, shattered rock, cemented and veined with calcite; all suggestive of fault zones that have hosted flow of geothermal waters from depth.

The conceptual model gleaned from all of the data assembled and collected to date is that the Wendover graben is the site of faulting and geothermal activity typical of other deep-circulation geothermal systems in the Great Basin. In this model, water that entered the fault systems in late Pleistocene times, during highstands of Lake Bonneville, has circulated to great depth where they gained heat and equilibrated with Paleozoic carbonate sedimentary rocks. These heated waters are now rising towards the surface along the faults bounding the graben. Chemical analyses show that the geothermal waters from the Blue Lakes are much less saline and contain lower total dissolved solids than waters in the shallow aquifers that provide brines to Intrepid's evaporation ponds. The tritium value of the Blue Lake water indicates that most of the Lake is "old" water (or pre-1952) that has been isolated from the atmosphere in a deep ground water flow pathway. Temperature logs of Intrepid's brine wells suggest that the brine aquifer tapped by these wells caps and partially masks the moderate to high geothermal gradients in the underlying sediments.

Synthesis of all information assembled and collected to date focus future exploration attention to the northwestern-most corner of Focus Area 1. This area is nearest the deepest point of the Wendover graben, is underlain by bounding faults of the graben, and is the site of thermal springs potentially fed by waters moving along those faults. The subsurface temperature distribution in the Intrepid area also suggests upwelling thermal waters along the boundary fault system. Using this information as a guide, a pattern of six temperature gradient wells in the northwestern section of Focus Area 1 are recommended to further evaluate the relationship of faulting to upwelling warm waters and to help with siting of the best locations for deep exploration wells. In addition, several detailed geophysical surveys are suggested to enhance the exploration effort. These include additional gravity survey lines, a high-resolution aeromagnetic survey, and electrical surveys, all aimed at refining the locations and orientations of graben-bounding faults, and finding the most permeable and hydrologically conductive parts of those faults.

In conclusion, all of the field data collected during 2011 and documented in the Appendices of this report indicate that there is reasonable potential for a viable geothermal resource along faults that bound the Wendover graben. Prospects for a system capable of binary electrical generation are especially good, and the possibility of a flash steam system is also within reason. The next steps should focus on securing the necessary funding for detailed geophysical surveys and for drilling a set of temperature gradient wells to further evaluate the resource, and to focus deep exploration efforts in the most promising areas. 


\section{CONTENTS}

ACKNOWLEDGEMENTS

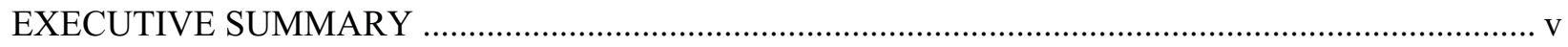

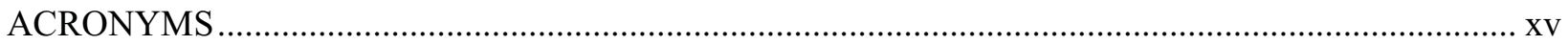

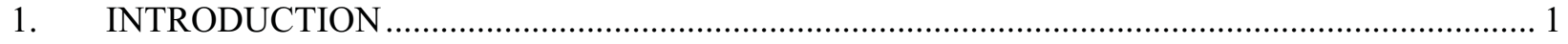

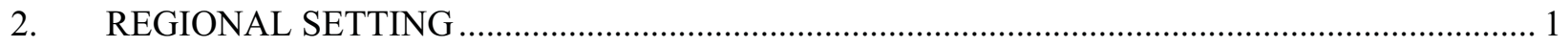

3. EXECUTIVE SUMMARY FROM THE PRELIMINARY REPORT …..................................... 2

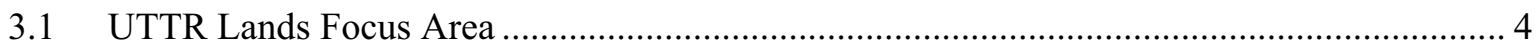

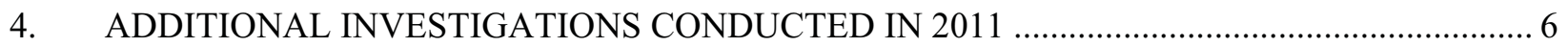

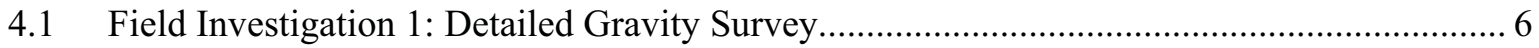

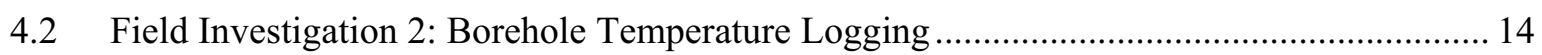

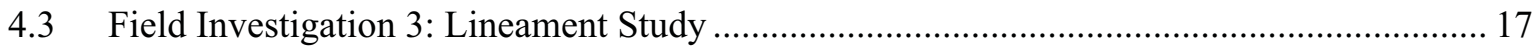

4.4 Field Investigation 4: Analysis of Borehole Geophysical Logs of Existing Wells ............... 20

4.5 Field Investigation 5: Sampling and Analysis of Surface Waters and Springs .................... 25

5. INTERPRETATION OF NEW DATA AND CONCEPTUAL MODEL ..................................... 31

5.1 Interpretative Synthesis of Results for the 2011 Field Activities........................................... 31

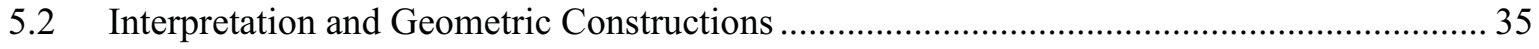

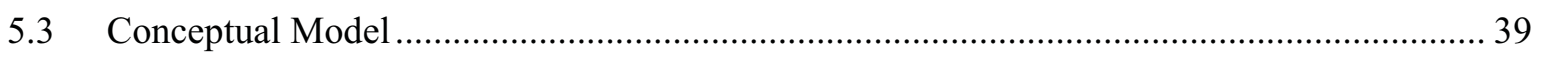

6. RECOMMENDATIONS FOR FURTHER EXPLORATION AND FOR EXPLORATORY

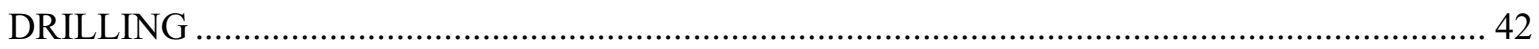

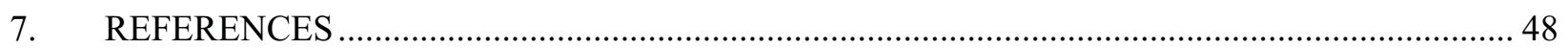

Appendix A - Western UTTR Gravity Surveys \& Processing ......................................................... A-1

Appendix B - Borehole Temperature Logging.......................................................................... B-1

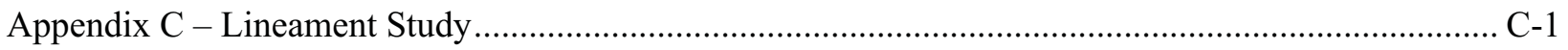

Appendix D - Analysis of Well Log Data from Wells Near Wendover, NV, for Estimation of

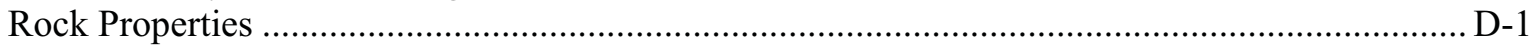

Appendix E - Sample and Analysis of Surface Water and Springs.................................................... E-1 


\section{FIGURES}

Figure 3.1-1. Detailed map of the Wendover Graben area and Focus Area 1. Graben-bounding faults shown by black dashed lines (Cook et al., 1964) and pink solid lines (this study); springs identified by blue dots, earthquake epicenters by green circles, seismic lines by red lines labeled SL1 through SL3, oil wells by heavy black circles, deep brine wells by red dots (DB3 = Deep Brine Well \#3; SS1 = Shell Salduro \#1; AMF1 = Alpha Minerals Federal \#1).

Figure 4.1-1. Existing gravity stations from the PACES database at the University of Texas, El Paso prior to this 2011 survey. Note the sparsity of stations within the western portion of UTTR-S, including all of Focus Area 1. This lack of gravity data precluded robust interpretation of the structure of the southward extension of the Wendover graben into and near Focus Area 1, until collection of new gravity data in 2011 .

Figure 4.1-2. Prioritization of areas for collection of new gravity data in 2011. Based on interpretations of existing gravity, on locations and orientations of lineaments (green dashed lines), and on location of thermal springs and lakes, the focus area was prioritized so that the areas most probably underlain by the Wendover graben were well covered.

Figure 4.1-3. Map showing the location and spacing of new gravity stations measured in 2011. Gaps in the pattern of new stations in the Intrepid area, just north of Focus Area 1, are due to large evaporation ponds that limit access. Also note that no new data was collected in the northern portion of the Priority 3 Area because of restricted access to this area of the UTTR-S.

Figure 4.1-4. Map showing contoured values (Inverse Distance Weighting) of the CBGA based on new data from the stations shown. Contour lines are color coded with cool colors representing low values and warm colors representing high values. Two different contour maps are shown. (A) Contour map of the CBGA values recorded at each of the 686 new gravity stations. (C) Contour map of the CBGA values calculated at each of the approximately 2800 grid nodes in an equivalent-source model with a $1 \mathrm{~km}$ grid size. (B) and (D) Faults (white lines) interpreted from the contour maps in (A) and (C), respectively.

Figure 4.1-5. Gridded model of the CBGA, shown with contours of the gridded gravity data at 5 mgal contour interval. Grid size is $1 \mathrm{~km}$, and CBGA ranges from $-170 \mathrm{~m}$ gal (bright yellow cells) to $-120 \mathrm{~m}$ gal (deep red cells).

Figure 4.1-6. Horizontal gravity gradient maps. (A) The data are processed to show the locations of areas with the greatest change in CBGA with horizontal distance (the bright yellow to white areas). (B) White lines are drawn over the areas of greatest horizontal gravity gradient and used in subsequent steps to establish the locations of faults in the subsurface.

Figure 4.2-1. Locations of the 13 wells where temperature data are available. Red dots are wells with temperatures reported by Turk (1973). Yellow dots are wells with 2011 temperature logs. Black circles filled in with red are oil and gas wells. 15

Figure 4.2-2. Temperature-depth profiles for each of the Intrepid potash wells logged in 2011. 16 
Figure 4.3-1. Locations of the 22 lineaments identified for the 2011 study, which trend primarily in a NE-SW direction in the center of the study area with NW-SE trending lineaments occurring more frequently near the perimeter of the study area.

Figure 4.3-2. Lineaments 3-6 in the central and northeast portion of Focus Area 1 provide the most interest for geothermal exploration. They are in the vicinity of a warm water spring known as Mosquito Willey's and cross the outflow from the Blue Lakes springs that lie northwest of Mosquito Willey's.

Figure 4.4-1. Map showing locations of Oil and Gas wells for which geophysical logs were obtained and analyzed. Large red-filled dots represent the wells; black dashed lines are faults inferred by Cook et al. (1964), and white lines are faults inferred by 2011 gravity data. On both fault interpretations, the ball shows the downthrown side.

Figure 4.4-2. Well logs showing the original logs (Correlation, Depth, Mudlog, Resistivity, Acoustic, and Density) and the calculated logs (VSHL, Porosity, Composition, and Permeability). The SS1 well log is shown on the left. The AMF1 well log is shown on the right.

Figure 4.4-3. Generalized NE-SW cross-section through the Wendover graben near wells SS1 and AMF1. Adapted from Cook et al. (1964). The gamma logs of each well are plotted as black traces beside the wells. The layer with the high gamma signature is indicated by the orange band. Inferred position of that layer within the Wendover graben proper is represented by the dashed orange band

Figure 4.5-1. Satellite image indicating the locations of the Intrepid and Blue Lake sampling areas.

Figure 4.5-2. Water samples were collected from wells 6, 7, 10, 12 and 13, located adjacent to the southeast flank of the Silver Island Mountains. 26

Figure 4.5-3. Satellite image of the Blue Lake area showing the locations of the four samples collected for chemical analyses.

Figure 4.5-4. Relationship between $\mathrm{Na}$ and $\mathrm{Cl}$ in the Blue Lake (BL) and Intrepid wells (IW). Waters from the Intrepid wells IW6, IW7, IW13, and IW10 could represent mixtures of water from IW12 and Blue Lake waters.

Figure 4.5-5. K-Na-Mg plot of Blue Lake area waters. The samples group at the lower boundary of the region where partial equilibration with the rock is expected. 30

Figure 5.1-1. Temperature-Depth plot of all the available temperature data for areas near Focus Area 1.

Figure 5.2-1. Locations of cross sections constructed to illustrate geometry of subsurface structure and temperature distributions. Also shown in this figure are: lineaments (dashed green lines); earthquake epicenters (green circles with blue dot in the middle); springs (light green circles with blue fill); faults interpreted from gravity data (heavy white lines with ball on downthrown side); petroleum exploration wells (heavy black circles with red fill); deep brine wells reported by Turk, 1973 (red dots); temperature contours based on temperatures reported by Turk, 1973 (red lines with temperature indicated $-30-80^{\circ} \mathrm{C}$ at $300-500 \mathrm{~m}$ depth). UTTR-S outlined in green; Focus Area 1 indicated by light cross-hatch. 
Figure 5.2-2. Cross-section $\mathrm{C}$ through the deepest part of the Wendover graben.

Figure 5.2-3. Cross-section DBW-3, through Intrepid's Deep Brine Well \#3. As in Cross-section $\mathrm{C}$, the white arrow indicates upflow of geothermal waters.

Figure 5.3-1. This regional cross-section extends from central Nevada (near Battle Mountain) to Salt Lake City, UT, and passes through the northernmost part of Focus Area 1.

Figure 6.0-1. Proposed additional lines of gravity stations (red lines) and boundaries for a highresolution aeromagnetic survey (blue polygon). Also, additional gravity stations are recommended for one of the lines acquired in 2011. Black dots with brown fill are gravity stations acquired in 2011. All other symbols are the same as those on previous figures.

Figure 6.0-2. Map showing suggested locations of temperature gradient wells and deep exploration wells in Focus Area 1. See the figure caption for Figure 5.2-1 for symbols. Suggested locations of temperature gradient wells shown by black circles with pink fill and numbered 1 through 6 . Potential locations for deep exploration well(s) are shown by red circles with black dots and numbered 7 and 8 .

Figure 6.0-3. Enlargement of the area near DBW-3 in Cross-section DBW-3, with potential situations encountered by thermal gradient or deep exploration wells. In this enlargement, the colored lines represent an interpretation of temperature contours based on Turk's 1973 data; the vertical dashed black lines represent potential drill holes; and white arrow indicates potential upwelling of geothermal water; and the light horizontal dashed black lines indicate depths from 1-5 km.

Figure A-1. Study area with existing and new gravity stations. Basemap is aerial photography of the Intrepid and UTTR areas. Priority areas are outlined in green. Coordinate crosses are 0.25 degrees apart. A total of 686 new stations were added in Priority Areas 1 through 3.

Figure A-2. Gridded complete Bouguer anomaly values, with horizontal gradients. Bouguer anomaly computed assuming $2400 \mathrm{~kg} / \mathrm{m}^{3}$ density. Grid computed at $1 \mathrm{~km}$ interval from all stations (shown as blue triangles), using an equivalent source technique (Cordell, 1992). Upper right panel shows the magnitude of the gradient; the bottom two panels are gradients in east and north directions.

Figure A-3. 3-D depth-to-basement modeling. Upper left panel is observed with CBGA and gridded at $1.5 \mathrm{~km}$ spacing from all stations. Upper right panel is the calculated gravity anomaly from the 3-D model. Lower left panel is misfit (residual) between calculated and observed grids, in mGal. Lower right panel is the depth model in meters below surface.

Figure A-4. Profile locations on gridded gravity anomaly and elevations. Left side shows profile locations on CBGA, in mGal. Right panel shows profiles on gridded elevations, in $\mathrm{m}$.

Figure A-5. Gravity models for profiles A, B, D, and E. Models computed assuming a -0.4 and $0.4 \mathrm{~g} / \mathrm{cc}$ density contrasts for sediment and basement $\left(2000\right.$ and $\left.2800 \mathrm{~kg} / \mathrm{m}^{3}\right)$. See text for discussion of model features.

Figure A-6. Gravity model for long NW-SE profile. Bodies assumed to have $2000-2800 \mathrm{~kg} / \mathrm{m}^{3}$ constant densities. 
Figure B-1. Map showing locations of deep brine wells and other wells at Intrepid Potash, Inc. Wendover, Utah operations. (Note: the federal government has retained the mineral rights to much of the private land depicted in this figure.)....

Figure B-2. Temperature-depth profiles of some of Intrepid Potash, Inc. deep brine wells near Wendover, Utah. Profiles measured by UGS personnel on 22 and 23 June 2011. Reported BHT value for DBW-3 (Turk, 1974), and corrected BHT values for the Shell Oil Salduro \#1 and the Alpha Gov't \#1 oil/gas exploratory wells are shown for reference.

Figure C-1. NAIP image overlain with faults/lineaments in the Blue Lake area south of Wendover, Utah.

Figure C-2. 3-D rendering of the Blue Lake area from ArcGIS Explorer.

Figure C-3. Map of study area. Hill shaded digital elevation model displays topographic lows as white and highs as black. US Air Force property is cross-hatched in blue. Major roads, I-80 and Nevada State Road 93 are displayed as black lines. The location of the towns of Wendover, Utah and Nevada are marked with a red circle. Fault lineaments are shown as red lines, with corresponding red numbers. See text for a discussion of the lineaments. C-6

Figure C-4. Northern warm spring fed pool at Mosquito Willey's. Vegetation in the upper left portion of the picture shows the path taken by the waters emanating from the southern spring.

Figure C-5. Extensively brecciated limestone cut by a dense network of calcite veins near the warm spring at Mosquito Willey's.

Figure C-6. Calcite cemented conglomerate composed of locally derived limestone clasts deposited on a brecciated limestone outcrop cut by calcite veins. This outcrop is located to the photographers left in Figure C-2.

Figure C-7. White botryoidal calcite deposit adjacent to the northern warm spring at Mosquito Willey's.

Figure $\mathrm{C}-8$. Looking to the $\mathrm{N}$ from the vicinity of lineament \#3. The terrain is relatively flat although a few low sandy hills are present. Springs feeding Blue Lake discharge at the break in slope indicated by the white arrow.

Figure C-9. Looking S-to-SW from the vicinity of lineament \#3 toward the NW-to-SE trending outcrop. The springs of Mosquiot Willy's emanate from the SE end of the outcrop. from the SE portion of which emanate the springs of Mosquito Willey's. Lineament \#4 runs roughly perpendicular to this outcrop. No offset was observed. $\mathrm{C}-12$

Figure C-10. Shear zone in a limestone outcrop in the vicinity of lineament \#6. C-13

Figure C-11. White botryoidal calcite deposit at the base of a limestone outcrop in the vicinity of lineament \#6. The limestone contains dark brown chert nodules.

Figure C-12. Lineament \#6 follows the base of this NW-SE trending limestone fin. C-15

Figure C-13. Looking SE along lineament \#6 as it follows the base of this NW-SE trending limestone fin. Note the breaks in slope.

Figure C-14. Extensively brecciated limestone in the vicinity of lineament \#6. The outcrop is approximately $2 \mathrm{~m}$ in height.

Figure C-15. Brecciated limestone cemented by calcite. C-18 
Figure C-16. Botryoidal calcite deposits filling a fracture in a limestone outcrop.

Figure C-17. Light colored botryoidal calcite deposits coating the entire height of the limestone fin. The outcrop is roughly $10 \mathrm{~m}$ tall.....

Figure C-18. Looking north toward a steep trapezoidal planar slope face that is roughly parallel to lineament \#7. Lineament \#7 crosses the picture between the spot the photo was taken and the distant slope. No topographic feature was observed.

Figure C-19. Change in vegetation that roughly parallels lineament \#7. Looking to the SE from near the bottom of the planar slope face shown at the far right of figure C-16.

Figure C-20. Looking to the SW where lineament 8 crosses through the saddle (white arrow).

Figure $\mathrm{C}-21$. Looking to the $\mathrm{N}$ at a lake shore terrace that can be seen running from the west (left) to east (right) across the image (yellow arrow). Lineament \#7 runs in from of the planar face shown in Figure C-16 (at the far right). Lineament \#8 cuts through the saddle shown by the white arrow. There is no offset between the lake terraces.

Figure C-22. Northern edge of 'Rocky Point' associated with lineament \#9. The lineament follows this feature around to the east (left)

Figure C-23. Lineament $\# 10$ cuts through the saddle perpendicular to lineament $\# 9$ which runs along the base. A lake terrace can be correlated from one side to the other demonstrating that there hasn't been any offset since the lake level was last at this height. A thick band of limestone is also found just above the lake terrace on both sides of the saddle.

Figure C-24. Brecciated limestone cut by calcite veins, with a small piece of light colored botryoidal calcite on the exterior of this outcrop near lineament $\# 9$.

Figure C-25. Calcite-cemented conglomerate found in outcrop near lineament \#9. C-25

Figure C-26. Looking SW at where lineament \#14 was mapped crossing in front of the foothills running from the NW (right) to the SE (left).

Figure C-27. Outcrop in the vicinity of lineament \#14, which showed little evidence of tectonism.

Figure C-28. Vicinity of lineament 12 which was flat and densely vegetated.

Figure D-1. Google Earth satellite image showing the seven oil and gas wells in relation to Focus Area 1, which is outlined in red.

Figure D-2. GeoGraphix PRIZM ${ }^{\mathrm{TM}}$ was used to perform a baseline correction operation. The original SP curve appears in blue and the new baseline is shown in red.

Figure D-3. Porosity-resistivity cross-plot with a regression line extrapolated to the $100 \%$ saturation line, indicating the formation water resistivity value. Plots such as this were generated for each formation.

Figure D-4. Shale volume-corrected density porosity as volume per volume (v/v) with respect to depth for well 43-045-30001. Porosities above 35\% are uncommon. Porosities greater than $30-35 \%$ are suspect (see text).

Figure D-5. Water saturation with respect to depth for well 43-045-30001.

Figure D-6. Matrix permeability with respect to depth for well 43-045-30001. Permeability was calculated as a function of porosity. Calculated permeabilities greater than $1 \mathrm{D}$ are suspect (see text). 
Figure D-7. Measured SP response (blue) and the corrected baseline (red). In this case, due to the relative resistivities of the drilling mud and the formation water, the SP shale baseline is on the left and deflection to the right indicates clean intervals.

Figure D-8. Gamma ray responses from wells 43-045-11076 and 43-045-30001. a) Gamma ray curves before correction for fault offset. b) Gamma ray curves after 950-ft offset. ........D-23

Figure D-9. Estimated neutron porosity as volume per volume (v/v) with respect to depth from well 43-045-11076. Porosities were estimated according to Equation 16. High- and low-porosity values were selected somewhat arbitrarily.

Figure D-10. Comparison of porosities (as volume per volume) between wells 43-045-30001 and 43-045-11076 after the 950-ft depth offset. The figure shows good correlation, particularly between 500 and $900 \mathrm{ft}$.

Figure D-11. Matrix permeability calculated from the estimated porosities using Jorgensen's model

Figure E-1. Satellite image indicating the locations of the Intrepid, Blue Lake, and Mosquito Willy's sampling areas.

Figure E-2. Water samples were collected from wells IW-6, IW-7, IW-10, IW-12, and IW-13, located adjacent to the southeast flank of the Silver Island Mountains.

Figure E-3. Satellite image of the Blue Lake area showing the locations of the four samples collected for chemical analyses.

Figure E-4. Satellite image of Mosquito Willy's springs showing north and south sample locations. E-8

Figure E-5. Sampling procedures included filtering of some samples.

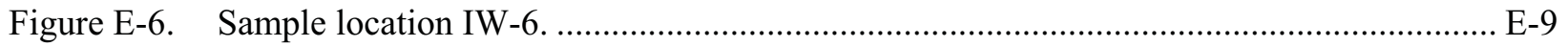

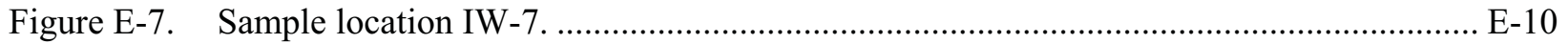

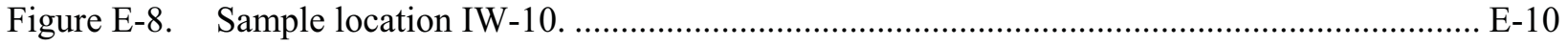

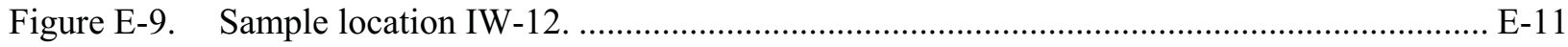

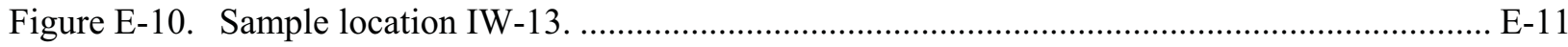

Figure E-11. Near sample location BL\#1. The sample was collected from a spring flowing into the pond, located by the figure standing in the tall grass on the right side of the

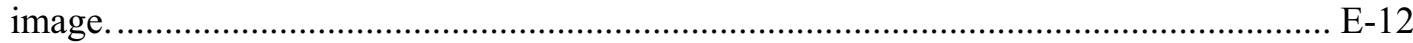

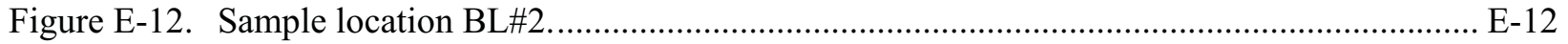

Figure E-13. Piper diagram of ions (\%meq/1) in waters from Intrepid wells (red), Blue Lake (blue), and Mosquito Willy's Springs (green). The diagram shows that samples from the various sets group together but there is little separation between groups. ........ E-13

Figure E-14. Relationship between $\mathrm{Na}$ and $\mathrm{Cl}$ in the Blue Lake (BL), Intrepid Potash, Inc., wells (IW) and Mosquito Willy's (MW) springs. Waters from the Intrepid Potash Inc. wells IW-6, IW-7, IW-13, and IW-10 could represent mixtures of water from IW12 and Blue Lake waters.

Figure E-15. K-Na-Mg plot of Blue Lake area waters. Blue Lake samples are shown in blue; Intrepid well samples are shown in red; Mosquito Willy's samples are shown in green. The samples group at the lower boundary of the region where partial equilibration with the rock is expected. 


\section{TABLES}

Table 4.4-1. List of seven oil and gas wells within $\sim 30$ miles of Focus Area 1...............................20

Table 4.4-2. Geophysical logs, tops of the Paleozoic rocks, total depth and bottom hole temperatures recorded in oil and gas wells near Focus Area 1.

Table 4.5.1. Compositions, measured and geothermometer temperatures of Blue Lake (BL) area and Intrepid (IW) well waters. Analytical values in mg/L. See Appendix E for laboratory analytical sheet for each sample.

Table 5.3-1. Summary of Rocks Exposed in Mountain Ranges West and Northwest of Focus Area 1, and therefore likely to be encountered in deep exploration wells beneath Focus Area 1.

Table 6.0-1. Additional geothermal exploration activities recommended for UTTR-S.

Table B-1. Summary of Intrepid Potash's “deep brine wells” near Wendover, Utah. Temperature profiles were measured in June 2011

Table D-1. List of seven oil and gas wells within approximately 30 miles of Focus Area 1.

Table D-2. Ground elevations, tops of the Paleozoic rocks, total depth and bottom hole temperatures recorded in oil and gas wells near Focus Area 1 ........................................ D-4

Table D-3. Porosity equations used in estimating sonic and density porosity (Asquith, 1983)...........D-4

Table D-4. Rock matrix parameters used in porosity equations......................................................... D-5

Table D-5. Equations and parameter values used in calculating sonic and density porosity

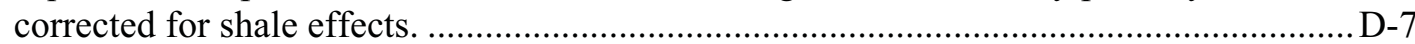

Table D-6. Formations identified in the well file...............................................................................

Table D-7. Results of formation water resistivity calculations by the SP method............................D-8

Table D-8. Results of formation water resistivity calculations by the $\mathrm{R}_{\mathrm{wa}}$ method..........................

Table D-9. Results of formation water resistivity calculations by the cross-plot method...................D-9

Table D-10. Comparison of the results of $R_{w}$ calculations from SP, $R_{w a}$ and cross-plot methods....... D-10

Table E-1. Compositions, measured and geothermometer temperatures of Blue Lake (BL) area, Mosquito Willy's (MW) springs, and Intrepid Potash, Inc. (IW), well waters. Analytical values in mg/L. See Attachment E-1 for laboratory analytical sheet for each sample. 


\section{ACRONYMS}

API American Petroleum Institute

CBGA complete Bouguer gravity anomaly

Dugway Dugway Proving Grounds

EGI Energy \& Geoscience Institute at the University of Utah

GSLD Great Salt Lake Desert

HAFB Hill Air Force Base

NAIP National Agricultural Imagery Program

PACES Pan American Center for Earth and Environmental Sciences

UGS State of Utah Geological Survey

USGS United States Geological Survey

UTTR Utah Testing and Training Range

UTTR-N Utah Testing and Training Range-North

UTTR-S Utah Testing and Training Range-South 
This page intentionally left blank. 


\section{Assessment of Geothermal Resource Potential at a High-Priority Area on the Utah Testing and Training Range-South (UTTR-S)}

\section{INTRODUCTION}

The purpose of this report is to summarize the current state of knowledge concerning potential high-temperature geothermal development on the lands controlled by Hill Air Force Base (HAFB) at the Utah Testing and Training Range (UTTR). This report is based on currently available published and publically available information and field data that was collected during 2011.

Much of the data gathered for this assessment of geothermal potential has been compiled as thematic layers, all at the same scale, so that diverse information can be compared and analyzed by means of map overlays. The material for the thematic layers was identified from literature searches and from published and unpublished maps.

During calendar year 2011, the following tasks were accomplished to assess the geothermal resource potential for the UTTR:

1. a comprehensive synthesis of existing and available information was compiled.

2. a preliminary report based on that synthesis was written (Smith et al., 2011).

3. investigations, including field activities that are detailed in this report, were conducted.

The following executive summary from the preliminary report is the starting point for this report. In addition the figures in the preliminary report serve to illustrate the types of geologic and geophysical information compiled and synthesized in task \#1, above. The additional investigations conducted after the preliminary report was issued are summarized and discussed in the sections following the preliminary report executive summary. The original data and reports for activities conducted during the summer of 2011 are presented in appendixes to this report.

\section{REGIONAL SETTING}

The UTTR lands are located within the Great Basin of the Basin and Range Province in northwestern Utah. Together, the Range and the Proving Grounds cover a large area of the Great Salt Lake Desert (GSLD). The UTTR is separated into two distinct areas, one north of Interstate 80 (UTTR-N) and one south of Interstate 80 (UTTR-S).

The GSLD is a structural basin (one of the larger basins within the Great Basin) which, like most basins of the province, has been filled with a thick sequence of Neogene, Quaternary, and Holocene sediments. Significant recent sediments covering the GSLD are fine muds and evaporite deposits associated with growth and desiccation of Lake Bonneville during Pliestocene glacial cycles.

The Great Basin Center for Geothermal Energy, located at the University of Nevada, Reno, has produced a map, which shows greater potential for the discovery of geothermal systems with warm colors and lesser potential with cool colors. The center's assessment is that the greatest discovery potential lies in the western part of the Great Basin (i.e., western Nevada) and along the Wasatch front in the state of Utah. This is because the geothermal systems in the Great Basin 
are deep-circulation systems that depend on circulation of groundwater to great depths along fault zones for their existence. Fluids must be able to circulate to depths as great as $9 \mathrm{~km}$ to be heated to temperatures sufficient for primary electric generation. Therefore, faults must extend through the upper crust and maintain open flow conduits in the current stress environment. Deep circulation and heating of significant quantities of groundwater can occur only on faults that repeatedly rupture (i.e., active faults) in current stress conditions, which keeps permeability pathways open. Therefore, areas with a higher strain rate are more favorable than areas with lower strain rates. Active faults (i.e., Quaternary and Holocene in age) occur mostly along the eastern margin and in the western part of the Great Basin, thus providing for the higher potential assessed in those areas.

\section{EXECUTIVE SUMMARY FROM THE PRELIMINARY REPORT}

This preliminary report (Smith et al., 2011) describes an in-depth investigation of relevant existing data that may be useful for evaluating the geothermal resource potential of the lands controlled by HAFB at the UTTR and the lands encompassed by the Dugway Proving Grounds. Assembled data include published journal articles and maps, as well as extensive collections of geothermal, geologic, geophysical, and geochemical data available from numerous university and government websites. Several geothermal focus areas are identified for future detailed analyses. The review and interpretation of the data presented herein indicates that within the focus areas of the UTTR are prospects that have characteristics similar to other geothermal reservoirs in the Great Basin. Recommendations are provided regarding additional data required to design a well drilling program to more fully characterize the geothermal potential southeast of Wendover, UT, in the western portion of UTTR-S.

The UTTR/Dugway lands are located within the Great Basin of the Basin and Range Province in northwestern Utah, an area of North America known to have thin crust, warm upper mantle rocks, high heat flow, and numerous geothermal systems, which can host geothermal power plants. The UTTR/Dugway area is situated in the GSLD, a structural basin that has been filled with a thick sequence of sediments. This thick sequence of sediments, as well as the waxing and waning of ice age lakes and the more frequent filling and draining of playa lakes, has masked deep subsurface geologic features. Understanding the geothermal regime here is further complicated by the lack of data in the area due to restricted access of large parcels of lands for military reservations. Nevertheless, the limited data from deep wells and the projection of geologic trends into the UTTR/Dugway area indicate a strong possibility that geothermal systems exist.

Four different geothermal exploration models for basin and range deep-circulation geothermal systems were described in this report (Smith et al., 2011). These models are sometimes called conceptual models and define the salient features of the geology, temperature regimes, and hydrogeology that must be present in order for a viable geothermal exploration target to exist. A geothermal system with commercial potential must have a combination of heat, water, and permeability. It is the coincident occurrence of multiple characteristics that contribute to the existence of a geothermal reservoir capable of electrical generation. The geothermal exploration models suggest that the location of the UTTR/Dugway lands within the Great Basin, near deep-seated faults, near regions of high extension rates, and over horst- and grabenbounding faults, makes it a prime exploration area for deep-circulation geothermal resources. 
The four exploration models are discussed in relation to a number of characteristics relevant to the discovery of geothermal systems on UTTR/Dugway Lands. The characteristics considered include: (1) the location within the Great Basin; (2) the geologic structure of the basin beneath the GSLD; (3) thermal gradient and heat flow; (4) thickness of basin-fill sediments; (5) resurfacing of basin floor; (6) thermal springs; (7) cold springs; (8) Quaternary faults; (9) contemporary seismicity; (10) source of water for geothermal systems; (11) characteristics of rocks in adjacent and intra-basin mountain ranges; and (12) lack of exploration due to a military presence. Four areas of the UTTR were identified that hold the most promise for the discovery of a geothermal resource.

Focus Area 1 was the first area considered for more detailed investigation during the summer and early fall of 2011. In addition to its favorable geologic and geophysical characteristics, Focus Area 1 is also in close proximity to existing power transmission lines, capable of handling power from a geothermal plant. Scientifically, this area is of interest for several reasons. First, the Blue Lakes Springs and other warm springs occur here and maintain a temperature of $84^{\circ} \mathrm{F}$. Second, the Wendover Graben (as identified from existing gravity surveys of the area) probably extends to the southwest from the area east of Wendover into this focus area. The southeastern side of the Wendover Graben has not been mapped into the Blue Lakes area yet, but an extrapolation of the gravity gradient motivated collection of additional gravity data during surveys of the area in 2011.

A complex system of two or more graben intersecting beneath the desert in the area south and southeast of Wendover is thought to exist in Area 1. Such intersections of graben and faults of different trends commonly produce extensive zones of fractured rock, which serve as pathways for the deep circulation of geothermal waters and for the development of near-surface geothermal reservoirs. Third, temperature data from several nearby petroleum exploration and deep brine wells suggest very high thermal gradients exist in the area. And finally, the presence of several earthquake epicenters east of Wendover suggest that the graben-bounding faults are still active, which is a condition favorable for maintaining open pathways for circulation of geothermal waters in the fault zones. Taken as a whole, the existing data are indicative of the conditions necessary for the presence of a significant geothermal resource in Focus Area 1.

Our results indicate that the best use of exploration funds is to focus on collecting data to better characterize the nature and extent of the Wendover Graben, searching for other evidence of geologic faulting, better characterization of the permeability of the deeper geologic formations, and collection of geochemistry data from wells and springs in the area to "finger print" waters for evidence of geothermal influences. These investigations were conducted during the summer and fall of 2011 include a high resolution gravity survey, geochemical sampling of springs and wells, temperature logging of deep wells (as available), evaluation of surface lineaments that might indicate deep structures, and a detailed analysis of available geophysical well logs for oil exploration wells. This data will be used for identifying drilling targets with high potential for a geothermal discovery in Focus Area 1.

It is noted that in the long-term, the other identified focus areas may be just as promising as Focus Area 1 and are worthy of more detailed exploration as well, and should not be neglected. Also, in large parts of UTTR-S and Dugway, so little geophysical and geologic data exist that subsurface interpretations are not possible. A long-term program of data collection in those areas may reveal other promising areas for geothermal exploration. 


\subsection{UTTR Lands Focus Area}

The available data for the GSLD provides rationale for selection of promising geothermal exploration areas on UTTR lands. It allows projection of favorable structures into the UTTR and comparison to analogous features in known geothermal systems. For this investigation, one area of the UTTR was selected and evaluated for its potential for discovery of a geothermal resource.

Focus Area 1: The western portion of UTTR-S - This area is of interest for several reasons. First, the Blue Lakes springs and other warm springs occur here. The Blue Lakes are fed by spring vents at the lake's bottom, and although the water temperature entering from the vents at this spot is not known, the lakes maintain a temperature of $84^{\circ} \mathrm{F}$ year round (Blackett and Wakefield, 2002). Also, the Wendover Graben and its associated bounding faults probably extends to the southwest from the area east of Wendover into the focus area. In fact, the warm springs at and near the Blue Lakes area may be localized by the southeastern graben-bounding fault. The southeastern side of the Wendover Graben has not been mapped into the Blue Lakes area yet, but an extrapolation of the gravity gradient data collected in this area was conducted during the summer/fall of 2011 and is presented in this report.

In addition, numerous springs in the area east and southeast of Wendover may also be localized by the graben-bounding faults. The oil wells southeast of Wendover and north of the focus area show that the thickness of sediment is about $3000 \mathrm{ft}$ east of the graben and greater than $3000 \mathrm{ft}$ within the graben. Gravity modeling indicates that the basin fill sediments in the deepest part of the graben is around $5000 \mathrm{ft}$ (Cook et al, 1965).

The presence of several earthquake epicenters east of Wendover suggest that the grabenbounding faults are still active, which is a condition necessary for maintaining open pathways for circulation of geothermal waters in the fault zones. In addition, several Quaternary faults mapped in the bedrock ranges northwest, north, and northeast of Wendover indicate contemporary tectonic activity in the area. Henrikson and Chapman (2002) show that heat flow calculated from an oil and gas well east of Wendover (specifically Alpha Minerals Federal \#1) and north of Focus Area 1 is $120 \mathrm{~mW} / \mathrm{m}^{2}$, which is among the highest heat flow values in Utah. Also, DB3, which is located about 5 miles southwest of Alpha Minerals Federal \#1 has a measured temperature of about $88^{\circ} \mathrm{C}$ at a depth of about 500 meters (Turk, 1973; Whelan and Petersen, 1974), suggesting a geothermal gradient of $176^{\circ} \mathrm{C} / \mathrm{km}$ (see Figure $3.1-1$ ). 


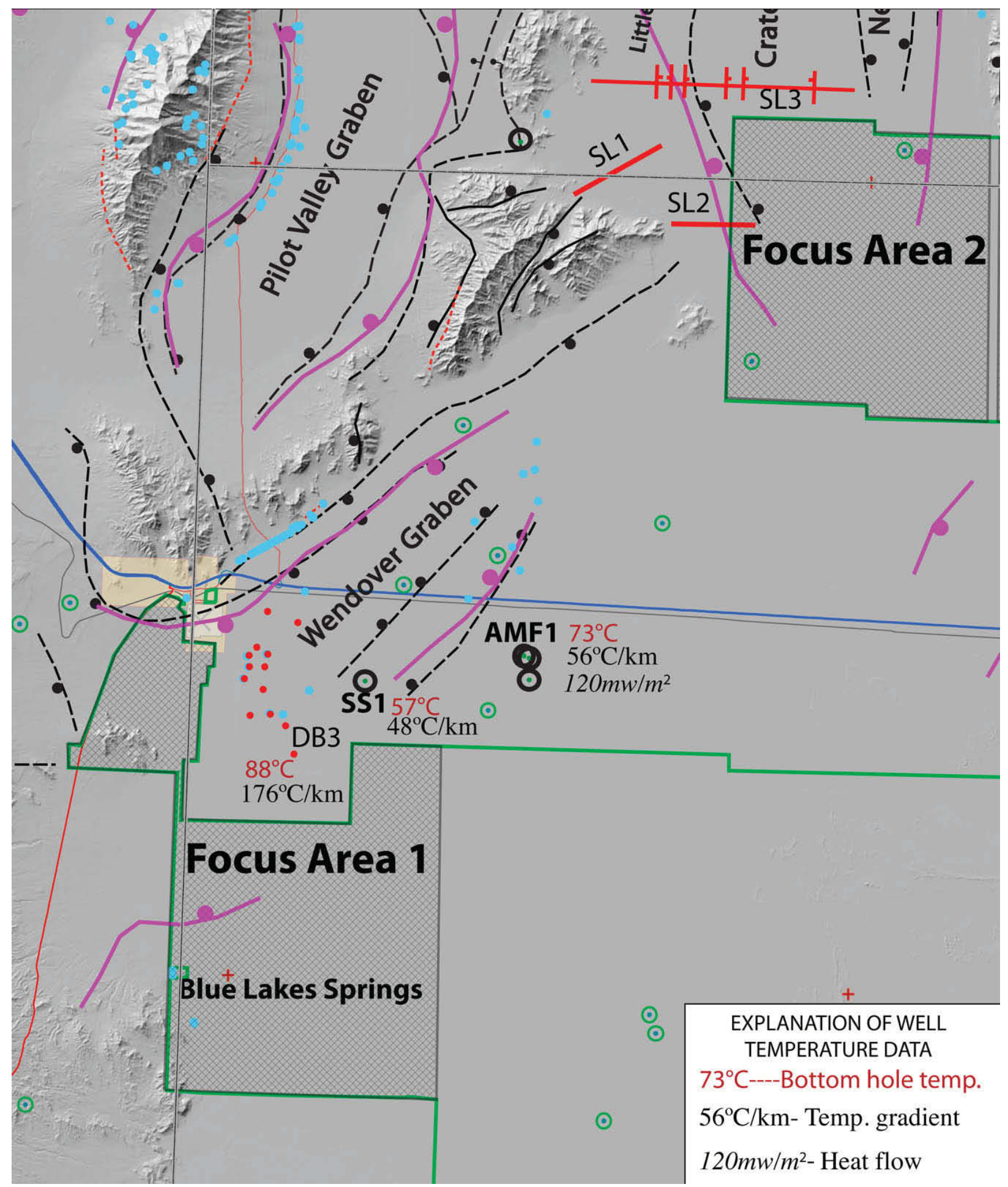

Figure 3.1-1. Detailed map of the Wendover Graben area and Focus Area 1. Graben-bounding faults shown by black dashed lines (Cook et al., 1964) and pink solid lines (this study); springs identified by blue dots, earthquake epicenters by green circles, seismic lines by red lines labeled SL1 through SL3, oil wells by heavy black circles, deep brine wells by red dots (DB3 = Deep Brine Well \#3; SS1 = Shell Salduro \#1; AMF1 = Alpha Minerals Federal \#1). 


\section{ADDITIONAL INVESTIGATIONS CONDUCTED IN 2011}

Because most of the land encompassed by Focus Area 1 is under military (UTTR) and industrial (Intrepid, Inc. potash operations) control, little geologic, geophysical, and geochemical information is available. In order to increase our understanding of the subsurface geology and temperature distribution in the area, a field campaign consisting of five different field investigations was conducted in 2011.

\subsection{Field Investigation 1: Detailed Gravity Survey}

Description. A field campaign to acquire new gravity stations in and near Focus Area 1 was designed and performed. The gravity survey was designed to provide sufficient data to fill in the large area of few existing stations in the western part of UTTR-S, and to provide sufficient detail to evaluate the geometry of the southward extension of the Wendover graben into Focus Area 1. The survey consisted of 686 new gravity stations arranged in 17 east-west oriented lines. The lines are approximately $2 \mathrm{~km}$ apart and in-line spacing between stations is $400 \mathrm{~m}$ or $800 \mathrm{~m}$, depending on difficulty of access and time available for surveys (see Figures 4.1-1, 4.1-2, and 4.1-3). In addition, the raw gravity data were converted to a complete Bouguer gravity anomaly (CBGA), and gridded to model basin depth and the magnitude of the horizontal gravity gradient. Also, 2D models were developed along several cross sections selected to provide details of the basement structure beneath the Focus Area. Details of data acquisition (field methods), data processing, and 2D and 3D modeling procedures are presented in Appendix A.

Results. The new gravity data are plotted as contours of the CBGA at each station, and as contours of the CBGA of each grid node in the gridded data (see a and c in Figure 4.1-4) to aid in interpretation of the subsurface structure. In each of the contoured maps, the areas of greatest horizontal gravity gradient (i.e., places where the gravity contours are closest together) are used to infer the positions of graben-bounding faults (see $b$ and $d$ in Figure 4.1-4). Although different in some details, the faults and overall shape of down-faulted basins (graben) inferred from contours of the station data (see Figure 4.1-4b) closely match those inferred from contours of the gridded data (see Figure 4.1-4d). The gravity data show that a deep northeast-trending graben extends through the Intrepid area just north of Focus Area 1 and through the northwestern part of Focus Area 1. Its deepest part occurs at its southern end, just west of the UTTR boundary and a little north of Blue Lakes springs. It defines the southern portion of the Wendover graben, first identified and modeled by Cook et al. (1964) based on gravity data that mostly covered the area north of Wendover.

In addition to defining the southern part of the Wendover graben, a second deep basin is indicated just southwest of Wendover. It extends southeastwardly from the Goschute Mountains and intersects the Wendover graben near it deepest point, near the northwestern corner of Focus Area 1 (see $b$ and $d$ in Figure 4.1-4). Although the NW-trending graben is shorter and narrower than the Wendover graben, its zone of intersection with the Wendover graben is likely to consist of intersecting fault zones with enhanced permeability to geothermal fluids. 


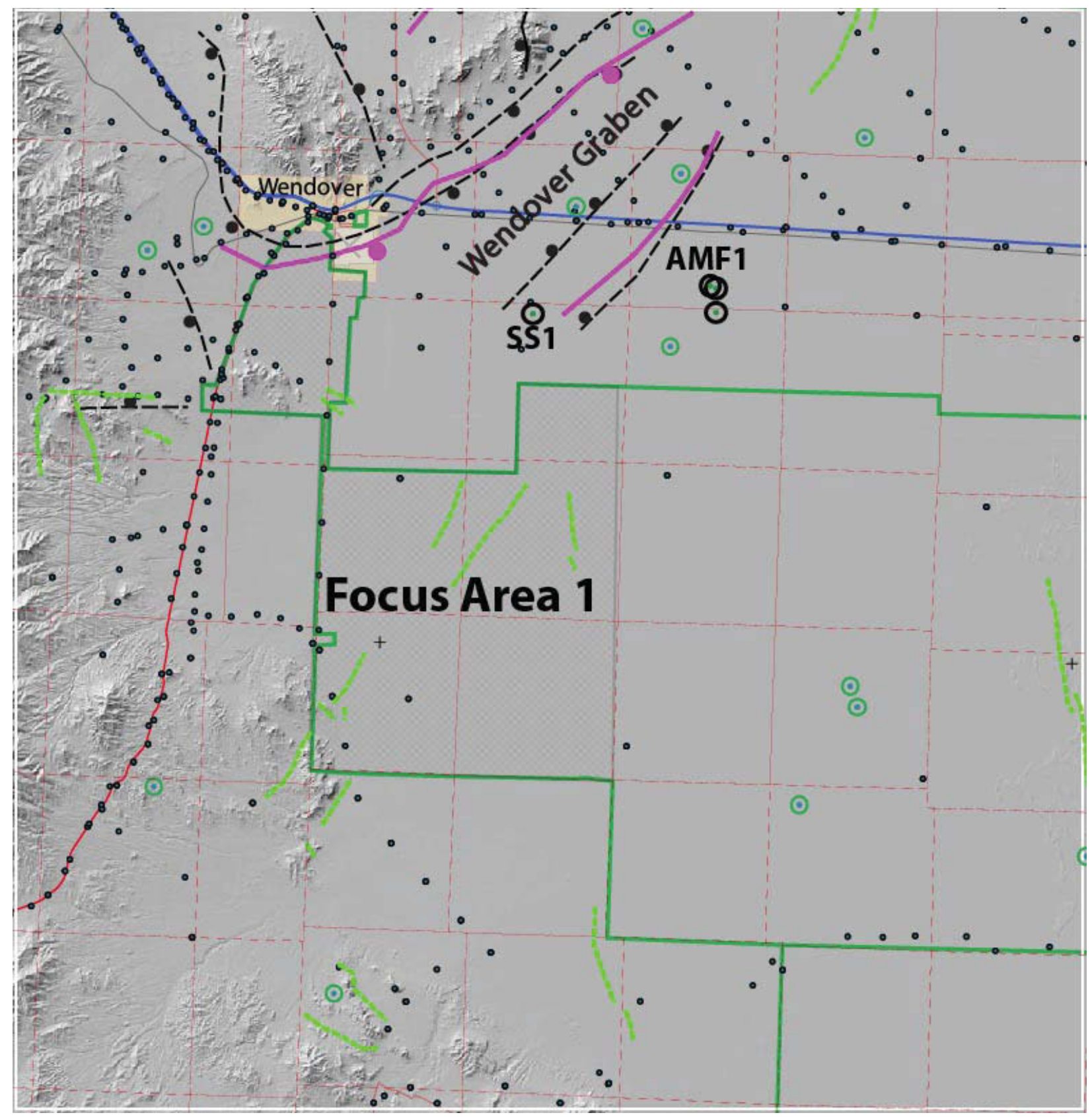

Figure 4.1-1. Existing gravity stations from the PACES database at the University of Texas, El Paso prior to this 2011 survey. Note the sparsity of stations within the western portion of UTTR-S, including all of Focus Area 1. This lack of gravity data precluded robust interpretation of the structure of the southward extension of the Wendover graben into and near Focus Area 1, until collection of new gravity data in 2011. 


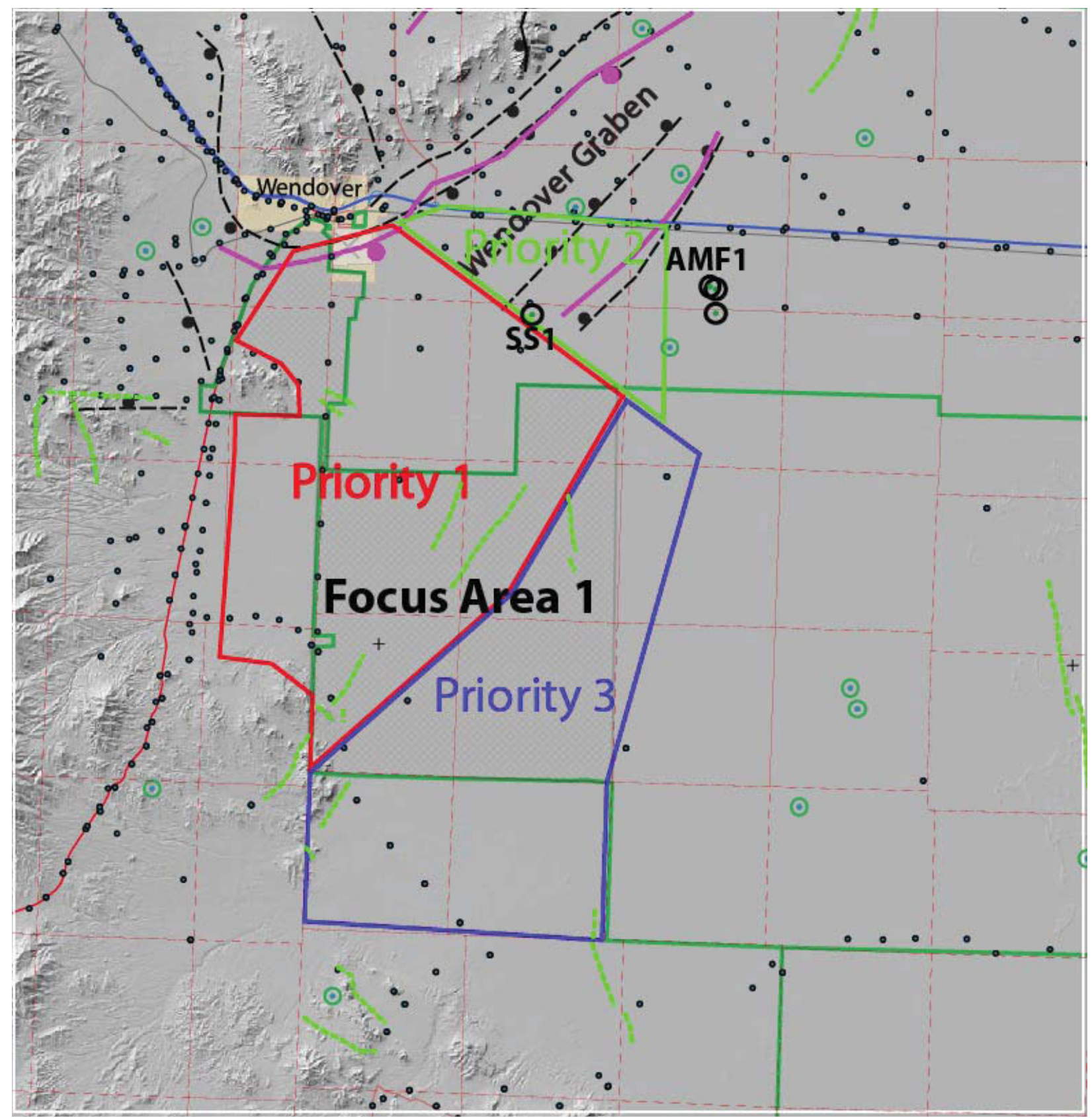

Figure 4.1-2. Prioritization of areas for collection of new gravity data in 2011. Based on interpretations of existing gravity, on locations and orientations of lineaments (green dashed lines), and on location of thermal springs and lakes, the focus area was prioritized so that the areas most probably underlain by the Wendover graben were well covered. 


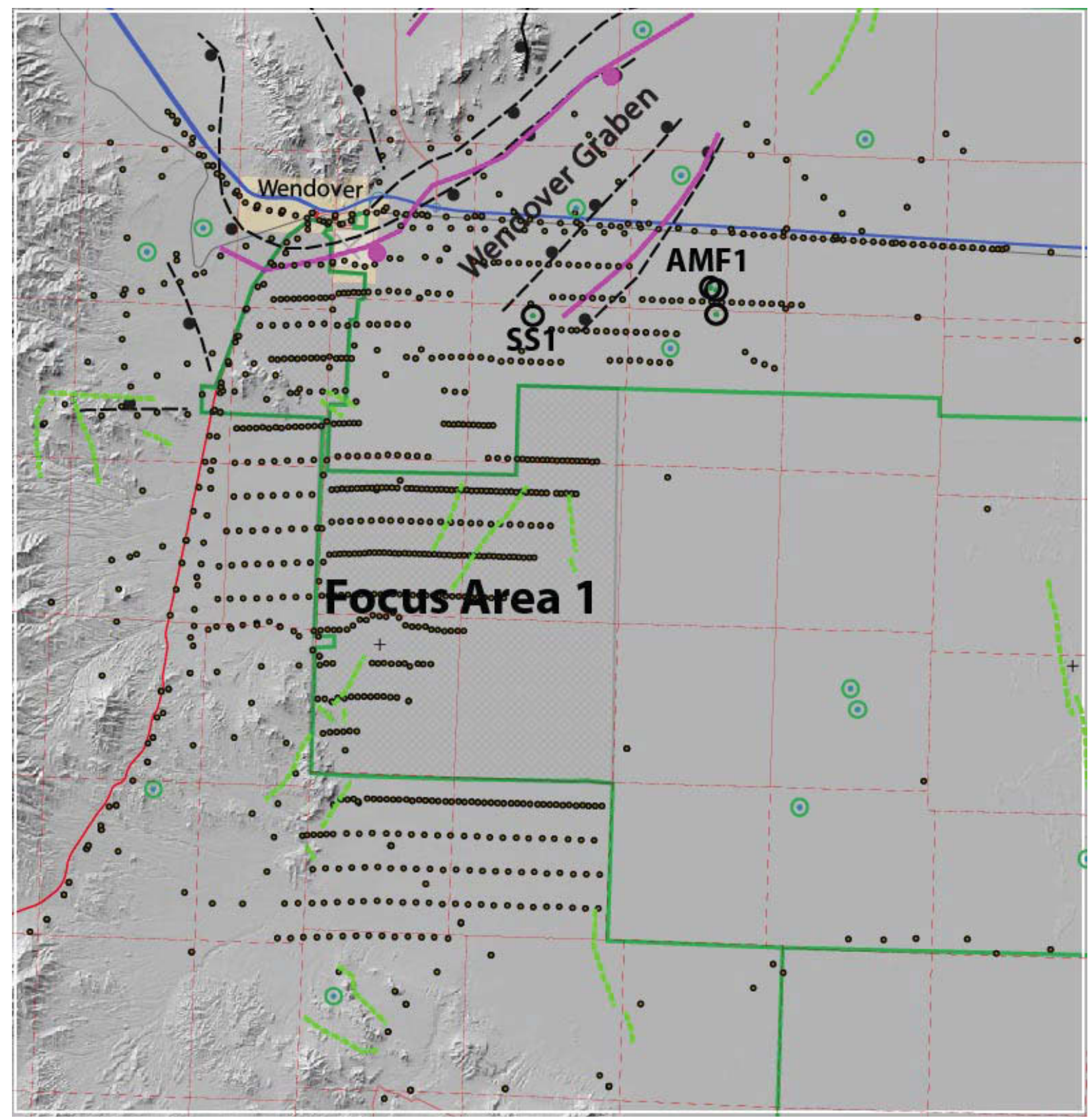

Figure 4.1-3. Map showing the location and spacing of new gravity stations measured in 2011. Gaps in the pattern of new stations in the Intrepid area, just north of Focus Area 1, are due to large evaporation ponds that limit access. Also note that no new data was collected in the northern portion of the Priority 3 Area because of restricted access to this area of the UTTR-S. 


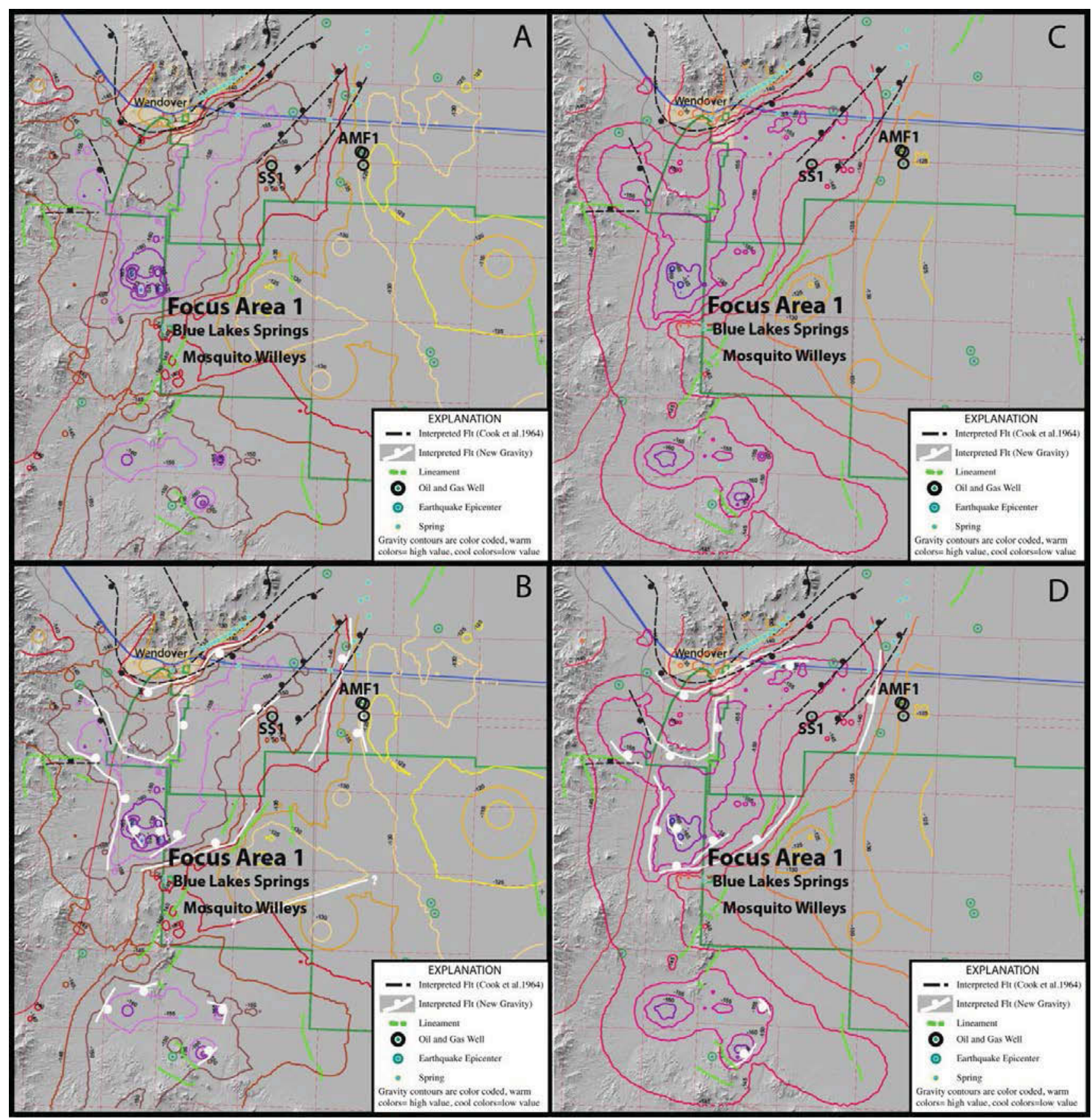

Figure 4.1-4. Map showing contoured values (Inverse Distance Weighting) of the CBGA based on new data from the stations shown. Contour lines are color coded with cool colors representing low values and warm colors representing high values. Two different contour maps are shown. (A) Contour map of the CBGA values recorded at each of the 686 new gravity stations. (C) Contour map of the CBGA values calculated at each of the approximately 2800 grid nodes in an equivalent-source model with a $1 \mathrm{~km}$ grid size. (B) and (D) Faults (white lines) interpreted from the contour maps in (A) and (C), respectively. 
Some important details of the subsurface structure are revealed by modeling of the new gravity data. For example, a gridded version of the CBGA, with $1 \mathrm{~km}$ grid cell size, is presented in Figure 4.1-5. Overlain on this representation of the gravity data are the contours of the gridded data at $5 \mathrm{mgal}$ contour interval. The gravity values range from around $-170 \mathrm{~m}$ gal (brightest yellow grid cells) to about $-120 \mathrm{~m}$ gal (deepest red grid cells). From this gridded model, a map of the areas of maximum horizontal gradient of the gravity values was developed, as shown in Figure 4.1-6a). This map, also gridded at $1 \mathrm{~km}$ grid cell size, simply shows the areas where the gravity values change most dramatically with horizontal distance (the lighter the color of the grid cell, the greater the change of the gravity values with horizontal distance). These areas of high gradient are associated with juxtaposition of rocks of significantly differing density, and are most likely to represent faults in the subsurface where dense basement rock is adjacent to less-dense basin-filling sediments. In Figure 4.1-6b, white lines are drawn on these areas of high gradient, and are used to infer the positions of graben-bounding faults in the subsurface (see Figure 4.1-4b and d). In each case, they are interpreted to be areas where there is a steep contact between lowdensity sediments inside the graben and high-density basement rock outside the graben.

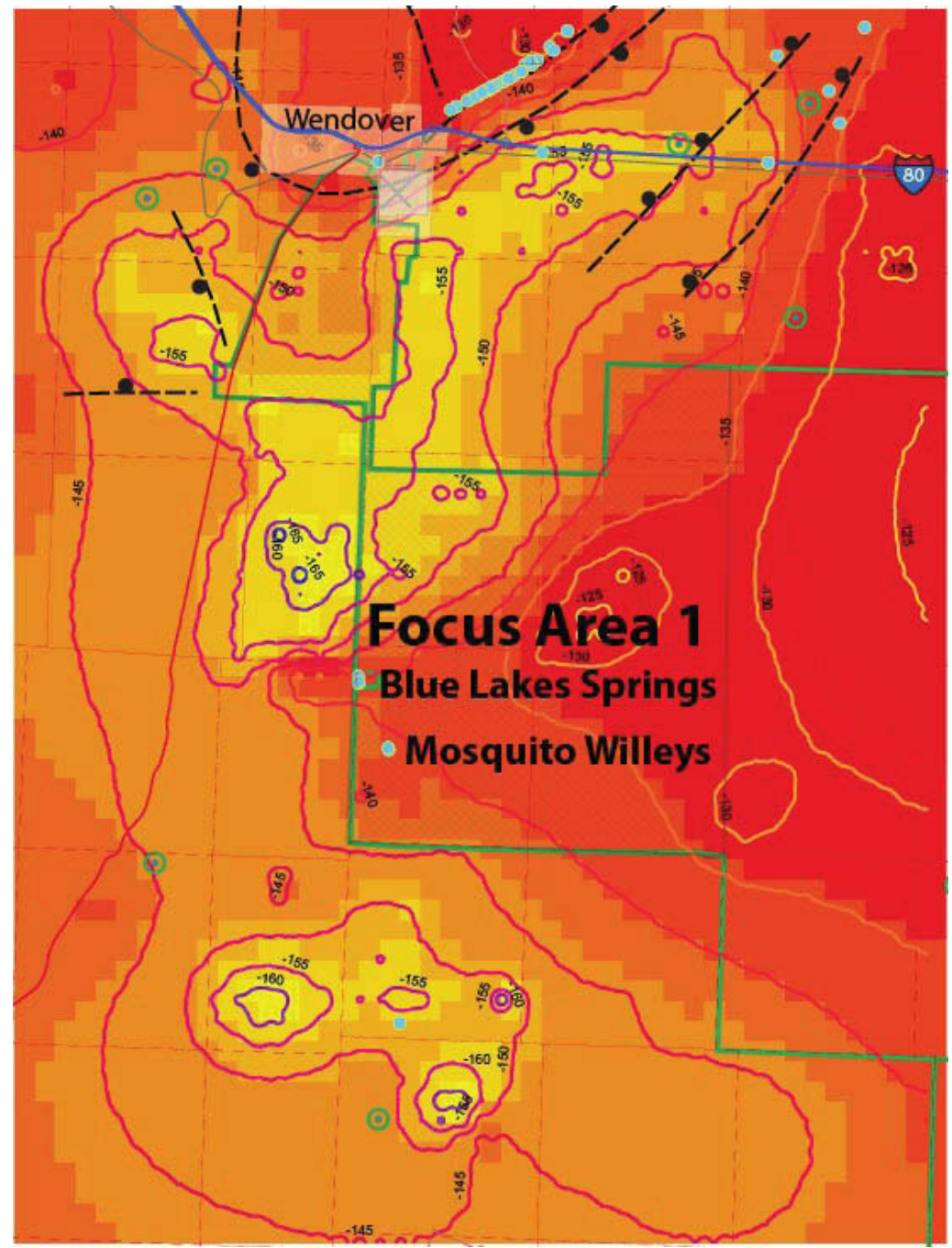

Figure 4.1-5. Gridded model of the CBGA, shown with contours of the gridded gravity data at 5 mgal contour interval. Grid size is $1 \mathrm{~km}$, and CBGA ranges from $-170 \mathrm{~m}$ gal (bright yellow cells) to $-120 \mathrm{~m}$ gal (deep red cells). 


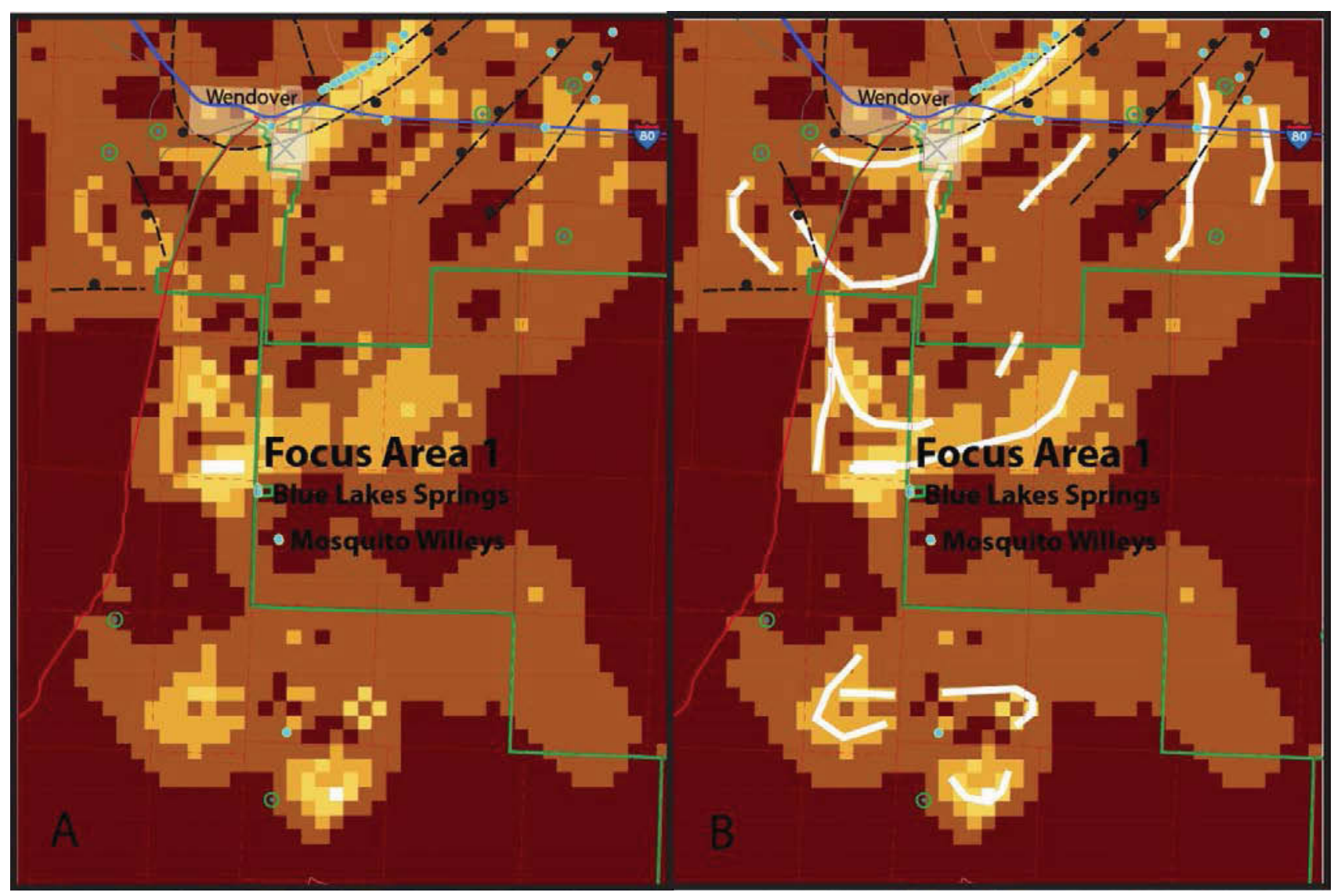

Figure 4.1-6. Horizontal gravity gradient maps. (A) The data are processed to show the locations of areas with the greatest change in CBGA with horizontal distance (the bright yellow to white areas). (B) White lines are drawn over the areas of greatest horizontal gravity gradient and used in subsequent steps to establish the locations of faults in the subsurface.

Additionally, the gravity data are used to model the depth to bedrock in the subsurface, i.e., the thickness of low-density sediments above the high-density bedrock of Paleozoic rocks (see Figure 4.1-7). This model covers a smaller area than that of Figures 4.1-5 and 4.1-6, and is gridded at a larger cell size $(1.5 \mathrm{~km})$. The areas with greatest depth to bedrock (bright yellow to white cells) and the overall shape of the graben system are revealed by this model. The depth associated with each cell is strongly dependant on the density contrast assumed for the rocks creating the gravity signature; unconsolidated sediments of the basin-fill material verses solid limestones, dolomites, sandstones, quartzites, and shales of the basement. No density measurements are available for the materials, but a range of reasonable density contrasts can be estimated from analogous rocks in other areas where density data is available. For that range of contrasts, the depth to the deepest parts of the basin (bright yellow to white cells) can range from around $2 \mathrm{~km}$ up to about $4 \mathrm{~km}$. Although the depth of each cell changes for different densities, the basic geometry and location of the modeled graben structure does not.

The depth model assumes that a uniform density is present in both the bedrock and the basinfill sediments. This assumption can lead to considerable uncertainty in interpretations of subsurface structure, especially in areas where heterogeneity of density is suspected. See discussions of the potential implications of this assumption in Sections 5.2 and 6. 


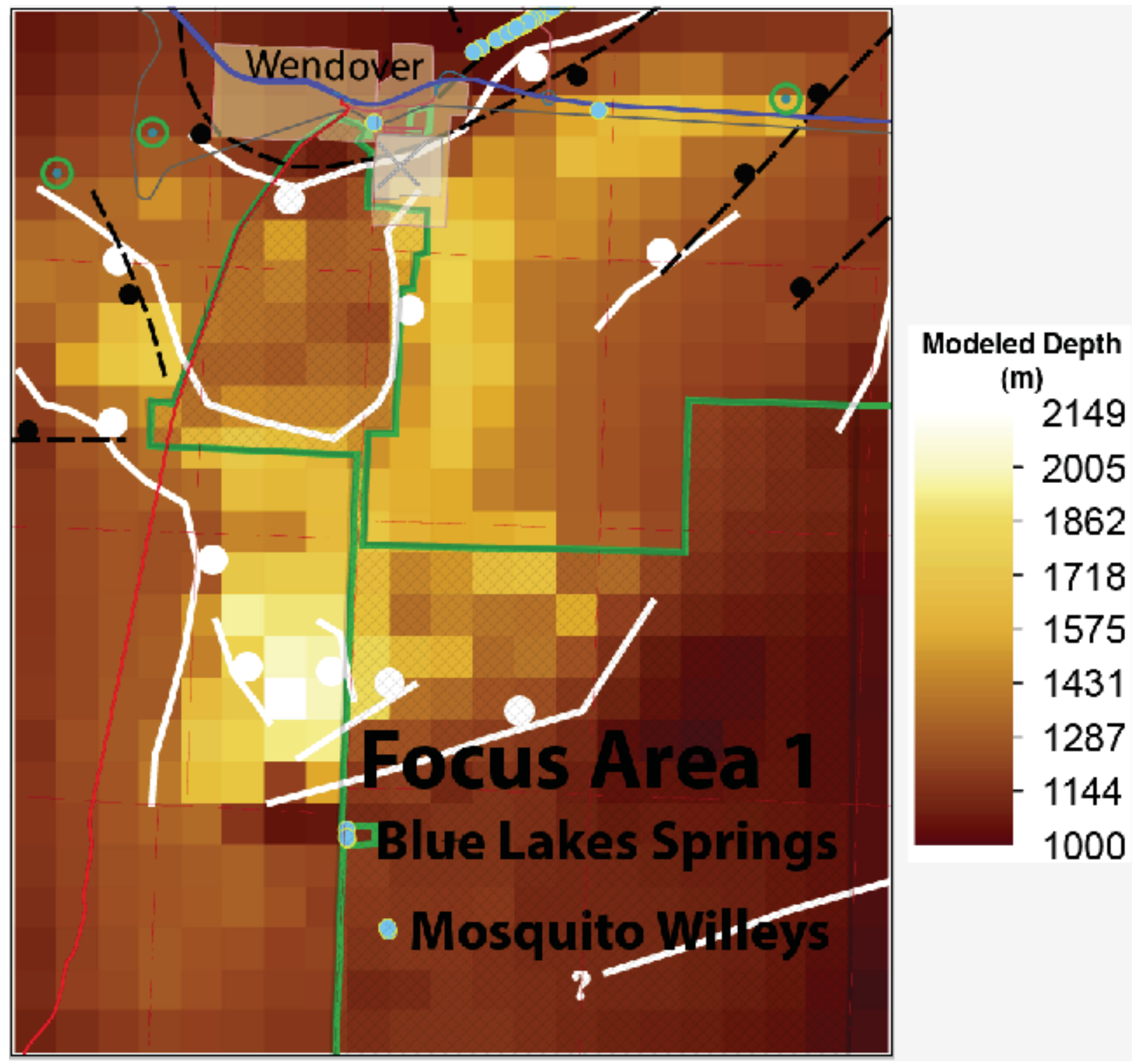

Figure 4.1-7. Depth to bedrock model. In this model, the gridded gravity data (1.5 km grid cells) are modeled to show depth to bedrock throughout the area, based on reasonable estimates of the densities (and thus density contrast) of the basin-fill sediments verses the basement rocks. Uniform densities are assumed for both bedrock and sediments. The color key shown here is for a high density contrast of $0.8 \mathrm{~g} / \mathrm{cm}^{2}$, which results in a maximum depth of about $2 \mathrm{~km}$. For more moderate density contrasts the maximum depth is up to $4 \mathrm{~km}$. Again, black dashed lines are faults inferred by Cook et al. (1964) while white lines are faults inferred from the 2011 gravity data. 


\subsection{Field Investigation 2: Borehole Temperature Logging}

Description. An important part of the field assessment was the temperature logging of wells around the UTTR-S area. Several existing wells in the Intrepid area on private lands just north of Focus Area 1 were available for temperature logging (see Appendix B for the detailed report). Temperature logging was conducted in six different wells by a team lead by Robert Blackett from the Utah Geological Survey on June 22-23, 2011.

Results. Locations of wells where temperature data are available are shown in Figure 4.2-1. A total of six wells were logged in 2011 (see Appendix B) and data for the other seven wells are reported by Turk (1973). The 2011 logging shows that static water levels in the wells ranges from 7.25-26.5 m. However, there is great variation in the depth of logging because the wells are blocked at different depths. Logged depths range from $85 \mathrm{~m}$ in the northern end of the well field to $410 \mathrm{~m}$ towards the south end. In spite of the variable depths available for logging, the new data provide two important advances over previously available data from Turk (1973). First, the well logs for two of the wells, DBW-17 and DBW-8, were logged to sufficient depth to provide corroboration of Turk's (1973) data. In DBW-17, the southernmost well logged in 2011, a maximum temperature of $44^{\circ} \mathrm{C}$ at $410 \mathrm{~m}$ was measured. Examination of Figure $4.2-1$ shows that DBW-17 is situated very close to DBW-1, for which Turk (1973) reported a temperature of $43^{\circ} \mathrm{C}$ at a similar depth of $366 \mathrm{~m}$. For DBW-8, the logged temperature of $24^{\circ} \mathrm{C}$ at $270 \mathrm{~m}$ is similar to Turk's reported temperature of $28^{\circ} \mathrm{C}$ at $343 \mathrm{~m}$ in the same well. These are important corroborations, because they lend additional credence to the high temperatures reported by Turk for DBW-1, and by analogy to the $88^{\circ} \mathrm{C}$ at $499 \mathrm{~m}$ reported for DBW-3. Confidence in Turk's (1973) data is important because it is the most complete data we have for subsurface temperature variations in the depth range of 300-500 $\mathrm{m}$ in the vicinity of Focus Area 1. The Turk (1973) data show a constant increase in temperature towards the southeast, towards Focus Area 1, and towards the southeast boundary fault system of the Wendover graben. See section 5 for additional interpretation of this data set. 


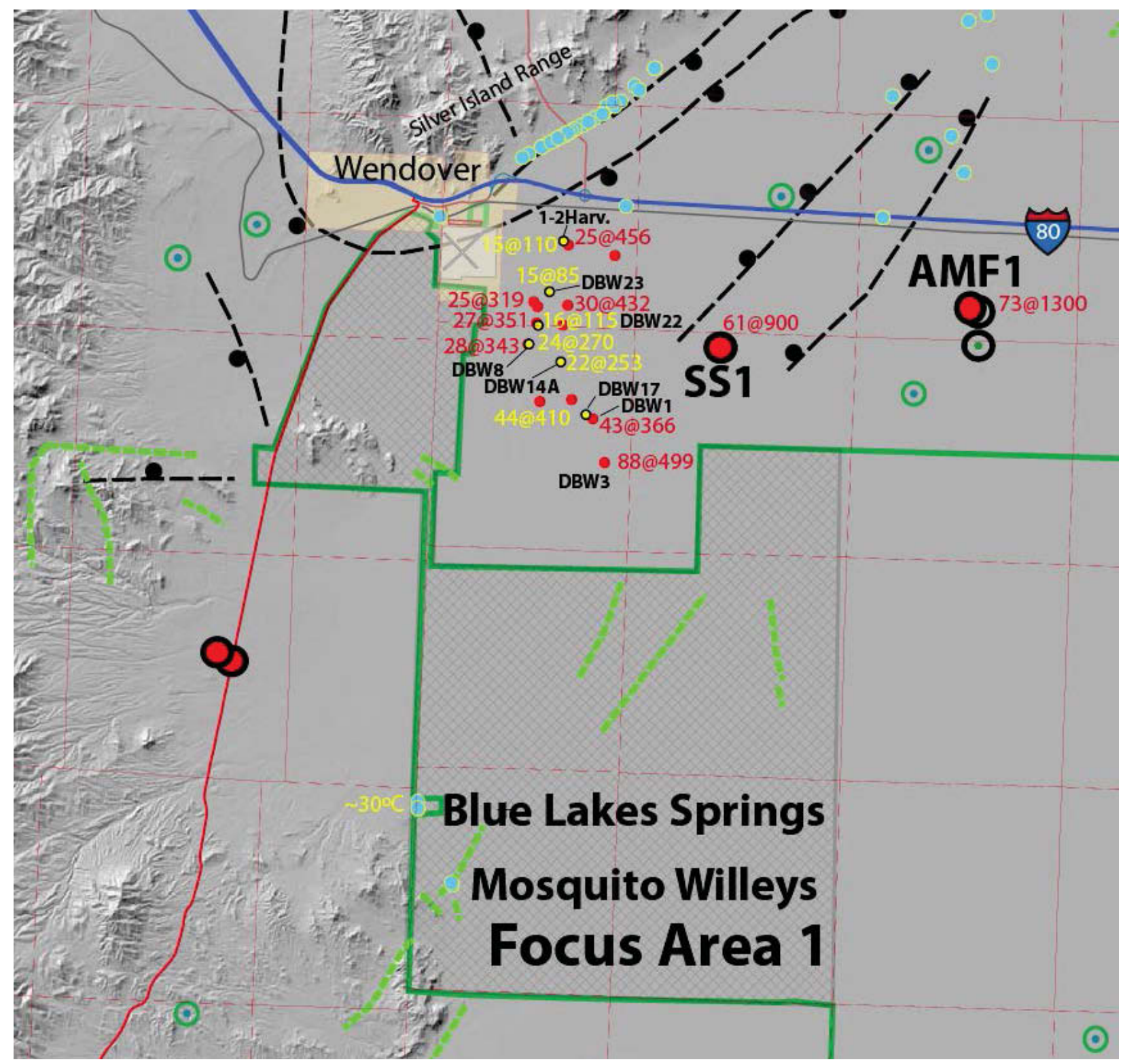

Figure 4.2-1. Locations of the 13 wells where temperature data are available. Red dots are wells with temperatures reported by Turk (1973). Yellow dots are wells with 2011 temperature logs. Black circles filled in with red are oil and gas wells.

A second valuable result of the 2011 temperature logging data by Blackett et al. (2011) (see Appendix B) is that it is the only data that allows for the confident estimation of thermal gradients in the area. Temperature-depth (TD) profiles for each of the wells logged in 2011 (see Figure 4.2-2) give robust geothermal gradient estimations for DBW-14 $\left(\sim 40^{\circ} \mathrm{C} / \mathrm{km}\right)$, DBW-8 $\left(\sim 57^{\circ} \mathrm{C} / \mathrm{km}\right)$, and DBW-17 $\left(\sim 70^{\circ} \mathrm{C} / \mathrm{km}\right)$. Although these thermal gradients were determined at different depth intervals and dictated by the depths to which logging was possible, they are typical of values reported for much of the Great Basin (Coolbaugh et al., 2005). The highest gradient occurs nearest Focus Area 1. 


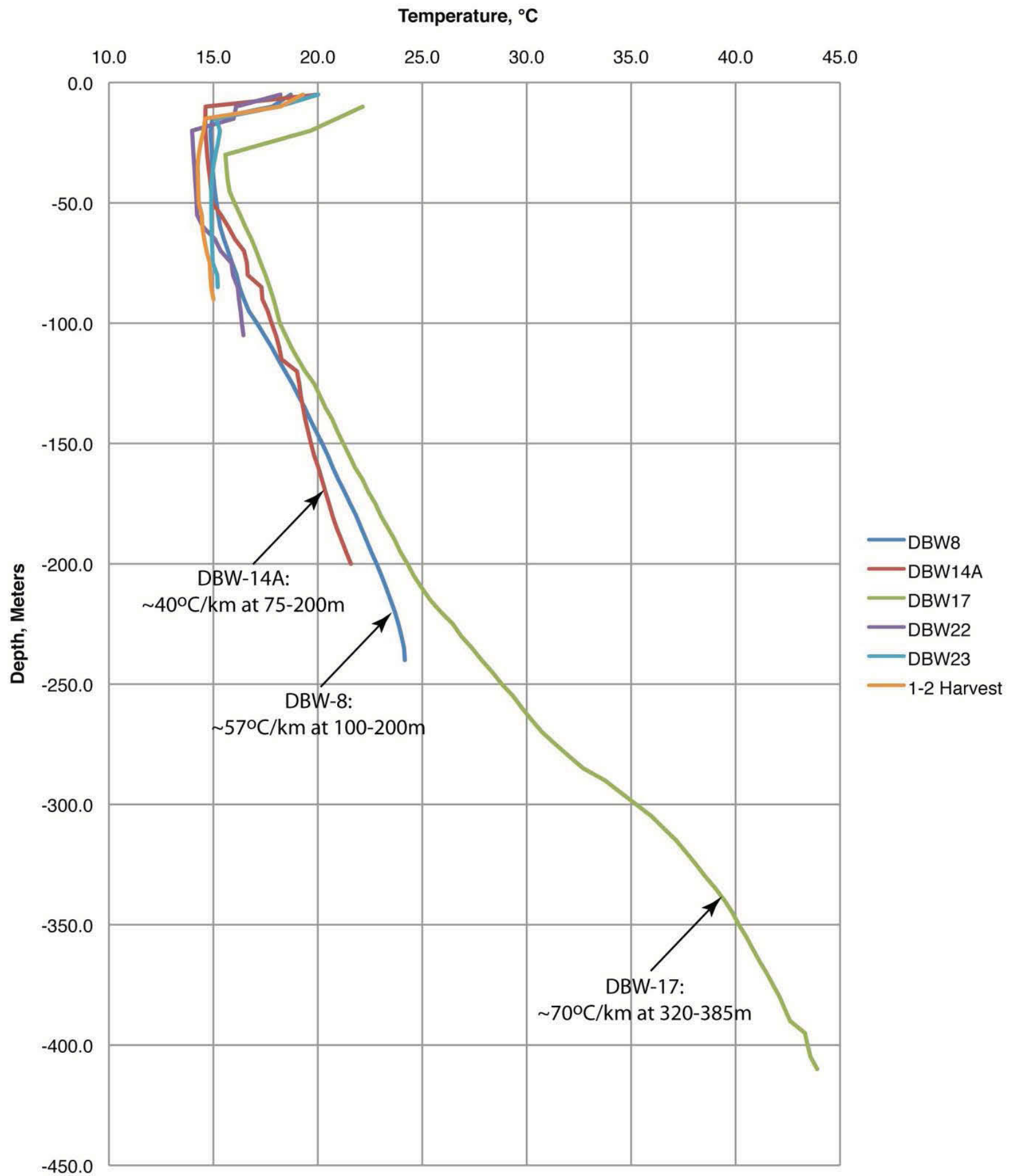

Figure 4.2-2. Temperature-depth profiles for each of the Intrepid potash wells logged in 2011. 
Even at the modest gradients suggested by the temperature log of $\mathrm{DBW}-17$ and corrected bottom-hole temperatures in Shell Salduro \#1 and Alpha Federal $\# 1\left(33^{\circ} \mathrm{C} / \mathrm{km}\right)$, temperature at $2 \mathrm{~km}$ depth (interpreted depth of the Wendover graben) is close to $100^{\circ} \mathrm{C}$ (probably sufficient for binary power production). If the average gradient of DBW-17 at $320-385 \mathrm{~m}\left(70^{\circ} \mathrm{C} / \mathrm{km}\right)$ is extrapolated to $2 \mathrm{~km}$ depth the temperature is around $150^{\circ} \mathrm{C}$. The gradients suggested by the $88^{\circ} \mathrm{C}$ temperature at about $500 \mathrm{~m}$ in DBW-3 $\left(170-265^{\circ} \mathrm{C} / \mathrm{km}\right)$ lead to temperatures of well over $200^{\circ} \mathrm{C}$ at $2 \mathrm{~km}$. These estimated gradients cannot be sustained to depth because they would lead to temperatures much higher than those in any known Great Basin deep circulation systems. Therefore, the gradients likely moderate or overturn with depth (decreasing temperature with depth after some maximum temperature is reached). If future drilling and temperature logging show that the gradients overturn, then the high temperatures encountered in DBW-17 and especially DBW-3 can be visualized as outflow from a geothermal system, probably lying to the south and east of DBW-3.

\subsection{Field Investigation 3: Lineament Study}

Description. The study of linear features (lineaments) on images of the earth's surface can sometimes help determine the location and character of deep seated geologic structures, including faults. An analysis of lineaments in and near Focus Area 1 was done because possible faults in the bedrock are buried beneath the thick sediments of the Great Salt Lake Desert. Linear features visible on the surface in many sediment-filled valleys of the Great Basin commonly provide useful information about the locations of faults. This is because faults in this environment grow while sediments accumulate in the valleys. Typically, faults move in a series of earthquakes that cause offset of the valley-fill sediments, but surface evidence of those offsets is quickly buried by younger sediments. Despite that burial, the fault disruption of deeper layers modifies the movement of groundwater (sometimes resulting in lines of springs), the distribution of surface water, the accumulation of sediments on the surface, and often allow fissures and collapse features to propagate to the surface. Additionally, burial can be incomplete, allowing small fault scarps to be identified. Although such modifications and incomplete burials are subtle, they produce variations in vegetation growth, soil moisture, soil color, and surface topography that are commonly visible on aerial photographs and other remote sensing imagery.

Lineament analysis for Focus Area 1 was performed using a combination of high resolution National Agricultural Imagery Program (NAIP) imagery and GoogleEarth imagery. The NAIP imagery helped in the identification of linear vegetation anomalies, soil color anomalies, and aligned springs that are commonly related to faults. Field inspections were performed by the University of Utah's Energy \& Geoscience Institute (EGI) to validate mapped lineaments (see Appendix C for a detailed description of EGI's lineament study).

Results. A total of 22 lineaments were identified in the study, as shown in Figure 4.3-1. The lineaments trend primarily in a NE-SW direction in the center of the study area with NW-SE trending lineaments occurring more frequently near the perimeter of the study area. Most of the field evaluated lineaments were either not found or there was no significant tectonic influence associated with the feature. Of most interest for geothermal exploration are the lineaments numbered 3 to 6 , as shown in more detail in the central and northeast portion of Figure 4.3-2. These lineaments are in the vicinity of a warm water spring known as Mosquito Willey's, and cross the outflow from the Blue Lakes springs that lie to the N-NW of Mosquito Willey's. 


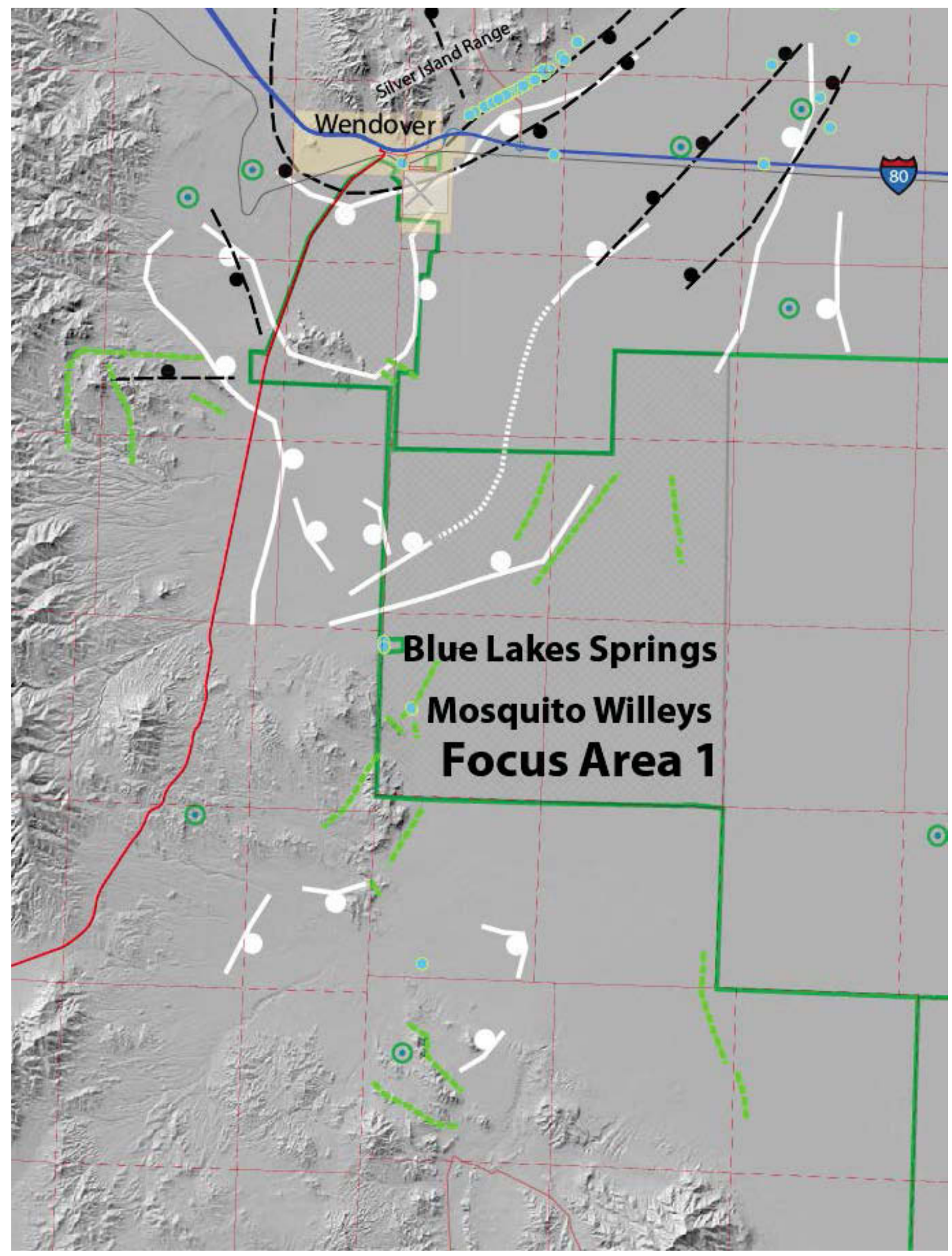

Figure 4.3-1. Locations of the 22 lineaments identified for the 2011 study, which trend primarily in a NE-SW direction in the center of the study area with NW-SE trending lineaments occurring more frequently near the perimeter of the study area. 


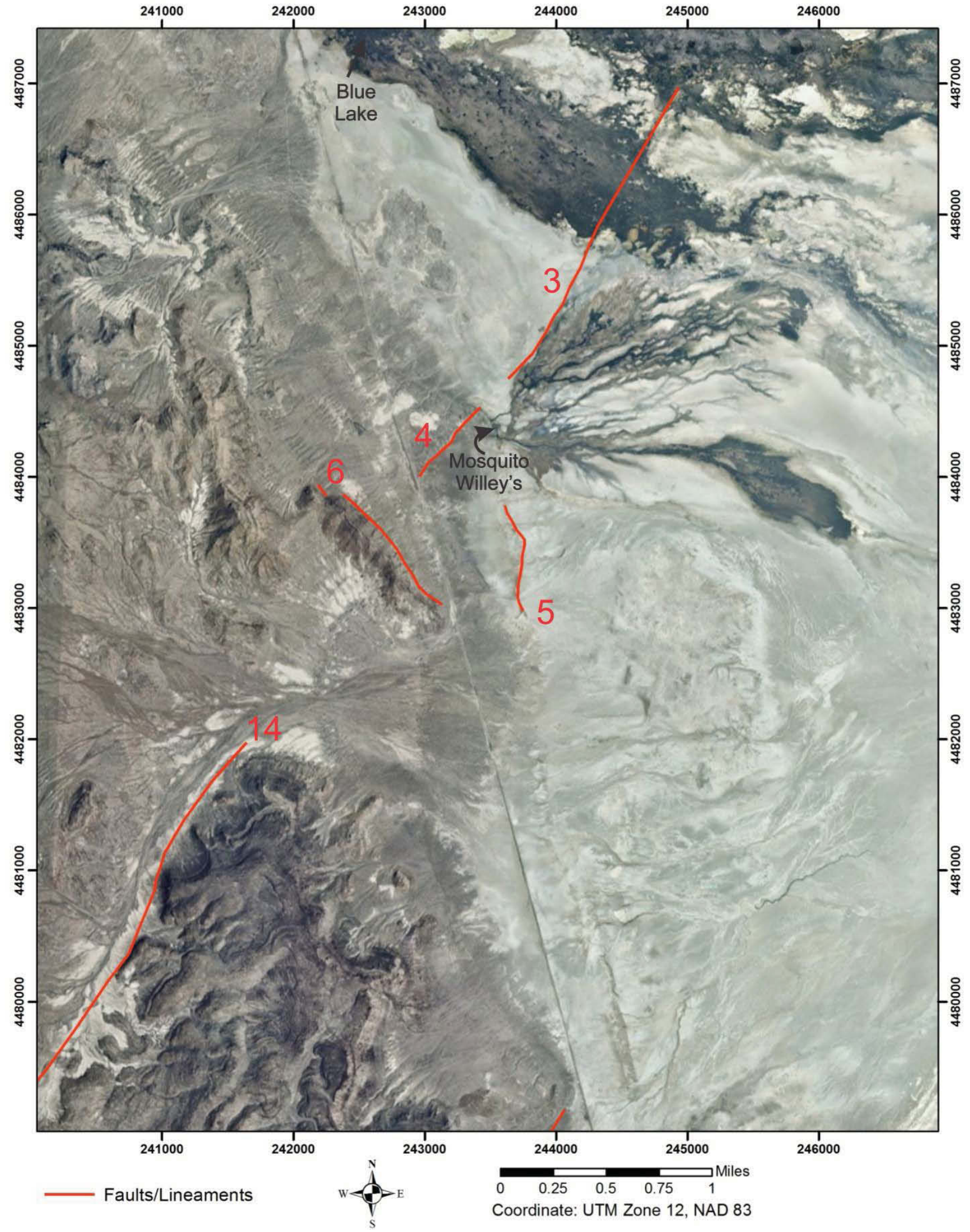

Figure 4.3-2. Lineaments 3-6 in the central and northeast portion of Focus Area 1 provide the most interest for geothermal exploration. They are in the vicinity of a warm water spring known as Mosquito Willey's and cross the outflow from the Blue Lakes springs that lie northwest of Mosquito Willey's. 
In addition to the springs, further evidence of tectonic activity are the outcrops immediately to the west of the springs that consist of breciated limestones, secondary calcite, and other materials that may have been derived from the footwall of a fault. The lineament also extends to the southwest into the low bedrock foothills where it defines a straight boundary between Neogene volcanics (rhyolite) and Paleozoic limestones. Limestones in outcrops directly west of the springs are brecciated (intensely broken into small, angular pieces by faulting), with fragments cemented together by hydrothermal or spring deposits of calcite. Such evidence of faulting suggests that these lineaments represent surface expressions of faults that provide permeable pathways for flow of warm waters from depth to feed the present spring systems. Taken as a whole this cluster of lineaments likely represent the surface expressions of both NE-SW and NW-SE trending faults from the intersecting grabens inferred from the new gravity data (see section 4.1).

\subsection{Field Investigation 4: Analysis of Borehole Geophysical Logs of Existing Wells}

Description. Examination and analysis of information available in existing wells is a viable way to learn about the characteristics of basin-fill sediments and basement rocks in the subsurface in and near Focus Area 1. Available information from the seven nearest oil and gas wells to Focus Area 1 was obtained from the Utah Division of Oil, Gas, and Mining (2011) and the Nevada Bureau of Mines and Geology (Hess, 2011) (see Table 4.4-1 and Figure 4.4-1). The information obtained includes borehole geophysical logs (caliper, gamma, density, neutron, sonic, and electric), from which porosity and permeability can be determined or estimated, various descriptive logs (sample descriptions, mud logs, core descriptions, formation tops), and well files (background information about the well including application for permission to drill well, maps showing well location, reasons for drilling, anticipated rocks to be encountered, and well completion data) (see Table 4.4-2 for a short summary of well information used in this study - further details can be found in Appendix D).

Table 4.4-1. List of seven oil and gas wells within $\sim 30$ miles of Focus Area 1.

\begin{tabular}{|cllll|}
\hline API No. & State & \multicolumn{1}{c}{ County } & \multicolumn{1}{c|}{ Operator } & \multicolumn{1}{c|}{ Well Name } \\
\hline 27-007-05001 & Nevada & Elko & Western Osage Oil, Inc. & Government No. 1 \\
27-007-05002 & Nevada & Elko & Last Frontier Oil Co. & Government No. 1 \\
27-007-05012 & Nevada & Elko & Gulf Oil Corp. of California & Owl Hill Federal No. 1 \\
27-007-05207 & Nevada & Elko & Shell Oil Co. & Goshute Unit No. 1 \\
27-033-05007 & Nevada & White Pine & Gulf Refining Co. & Dennison-Federal No. 1 \\
$43-045-11076$ & Utah & Tooele & Shell/Western Division & Salduro No. 1 \\
$43-045-30001$ & Utah & Tooele & Alpha Minerals & Alpha Federal No. 1 \\
\hline
\end{tabular}




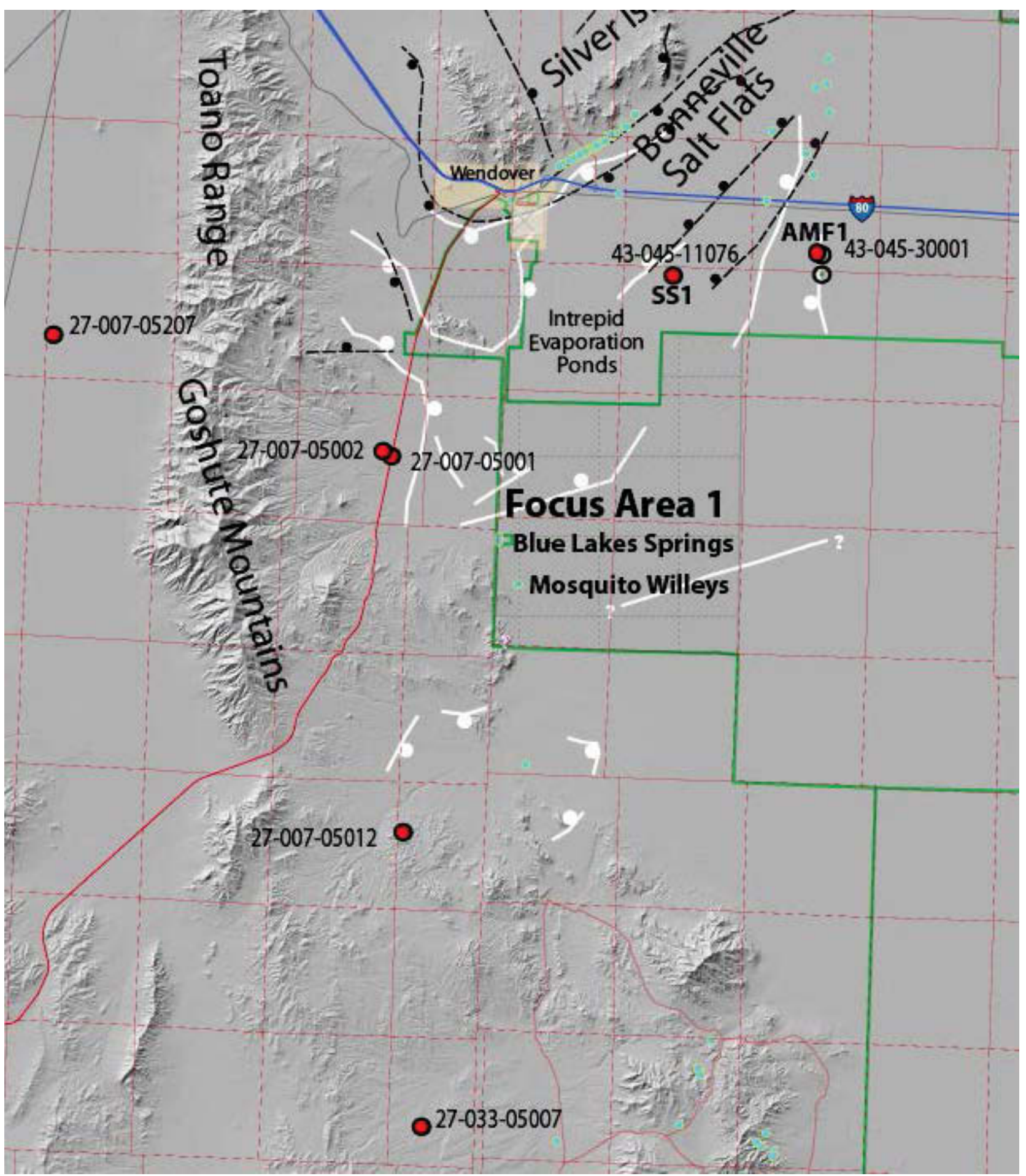

Figure 4.4-1. Map showing locations of Oil and Gas wells for which geophysical logs were obtained and analyzed. Large red-filled dots represent the wells; black dashed lines are faults inferred by Cook et al. (1964), and white lines are faults inferred by 2011 gravity data. On both fault interpretations, the ball shows the downthrown side. 
Table 4.4-2. Geophysical logs, tops of the Paleozoic rocks, total depth and bottom hole temperatures recorded in oil and gas wells near Focus Area 1.

\begin{tabular}{|c|c|c|c|c|c|}
\hline \multirow{2}{*}{ Well } & \multicolumn{2}{|c|}{ Geophysical Logs* } & \multirow{2}{*}{$\begin{array}{c}\text { Top of Paleozoic } \\
\text { (ft) }\end{array}$} & \multirow{2}{*}{$\begin{array}{c}\text { Total Depth } \\
\text { (ft) }\end{array}$} & \multirow{2}{*}{$\begin{array}{c}\text { Bottom Hole } \\
\text { Temp. } \\
\left({ }^{\circ} \mathbf{F}\right)\end{array}$} \\
\hline & Available & Digitized & & & \\
\hline $27-007-05001$ & $\mathrm{~N}$ & - & $?$ & 785 & $?$ \\
\hline $27-007-05002$ & $\mathrm{~N}$ & - & 590 (Permian) & 1327 & $?$ \\
\hline 27-007-05012 & $\mathrm{Y}$ & $\mathrm{Y}$ & 562 (Mississippian) & 1546 & $86(@ 1100 \mathrm{ft})$ \\
\hline $27-007-05207$ & $\mathrm{Y}$ & $\mathrm{Y}$ & 5280 (Permian) & 5569 & $140(@ 5434 \mathrm{ft})$ \\
\hline 27-033-05007 & Y & $\mathrm{Y}$ & 2215 (Permian) & 4498 & 120 \\
\hline 43-045-11076 (SS1) & Y & $\mathrm{Y}$ & N/A & 2950 & 132 \\
\hline 43-045-30001 (AMF-1) & $\mathrm{Y}$ & Y & 2970 & 4260 & $148-153$ \\
\hline
\end{tabular}

*Available logs include caliper, gamma, density, neutron, sonic, and various electric logs (SP, induction, resistivity/conductivity). In addition, sample description, core descriptions, and mud logs were available for some wells. Selected suites from the available logs were digitized for further analysis. For Shell Salduro \#1 (SS1) and Alpha Minerals Federal \#1 (AMF1), analyses of the log data were performed to estimate matrix porosity and permeability of the various rocks.

The two wells that are nearest to Focus Area 1 (43-045-11076 [Shell Salduro \#1 or SS1] and 43-045-30001 [Alpha Minerals Federal \#1 or AMF1]) are given the most attention in this study because they are most likely to provide information relevant to deep exploration, and because they are located on opposite sides of a fault inferred from gravity data. For these two wells, mathematical analyses of selected geophysical logs were performed to estimate porosity and permeability of some of the rocks (see Figure 4.4-2), and the gamma logs were closely compared to see if rock units could be correlated from one well to the other. Details of the analysis procedures, plots of resulting porosities and permeabilities, and plots of the logs themselves are discussed in Appendix D. 

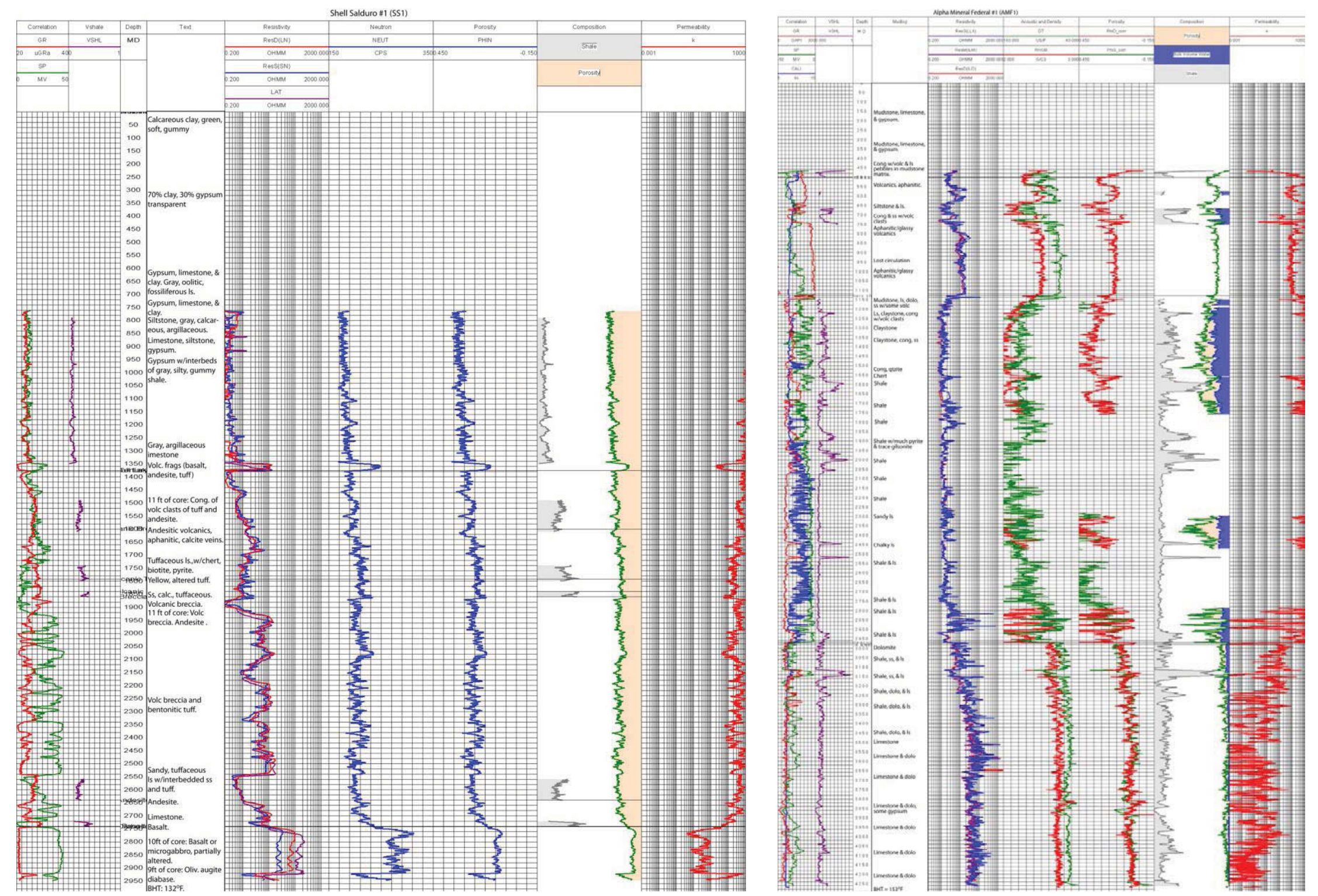

Figure 4.4-2. Well logs showing the original logs (Correlation, Depth, Mudlog, Resistivity, Acoustic, and Density) and the calculated logs (VSHL, Porosity, Composition, and Permeability). The SS1 well log is shown on the left. The AMF1 well log is shown on the right. 
Results. Two important results come from this investigation and analysis of existing well logs. First, the matrix permeabilities of the Paleozoic rocks that make up the basement beneath the basin-fill sediments is in the same range as matrix permeabilities measured in Paleozoic reservoir rocks in oil fields of the Great Basin (Schalla and Johnson, 1994). Such matrix permeabilities are at the low end of the permeability range (DiPippo, 2005) required for development of reservoir rocks in either oil fields or geothermal systems. However, lower Paleozoic carbonate rocks (limestones and dolomites) such as those make up the bedrock near Focus Area 1 host regional aquifers throughout the Great Basin with permeabilities sufficient to allow movement of groundwater between basins (Heilweil and Brooks, 2010). Such bedrock permeability can contribute to and enhance the development of a geothermal system. But fracture permeability, mainly contributed by active or recently active faults (especially intersecting faults of different trends and dips), is necessary for developing and sustaining viable geothermal reservoirs (and also petroleum reservoirs) in most Great Basin geothermal fields. Drilling and logging of numerous wells into these systems shows that fracture permeability allows the necessary voluminous flow of fluids (geothermal waters, oil, gas) (Schalla and Johnson, 1984; Blackwell, 2007; Blackett et al., 2004).

Porosities and permeabilities in the sedimentary basin-fill rocks above the Paleozoic basement rocks are significantly greater than that in the basement rocks. Although the uncertainties associated with the estimated porosity and permeability are large, it is clear that the basin-fill sediments are poorly compacted and lithified, and can conduct much more water that the basement rocks. This is relevant because it helps to explain the sometimes puzzling locations of hot springs near Focus Area 1, and because the Cenozoic basin-fill rocks could contribute to permeability of a potential geothermal reservoir in the deepest parts of the basin. The two hot spring systems near Focus Area 1 are the Blue Lakes Springs and Mosquito Willey's Springs. Mosquito Willey's Springs are located on a distinct NE-trending lineament, which suggests that the water is moving upward along a fault zone that penetrates through the Cenozoic sediments to the surface. However, no major lineament is recognized for the Blue Lakes system; that spring system may be fed, instead, by water flow that separates from a fault zone at depth and flows to the surface through the sediments themselves.

The second important result of the well log investigation, unrelated to porosity and permeability information, is the potential correlation of Cenozoic units between wells SS1 and AMF1. Figure 4.4-1 shows the two well locations in relation to faults interpreted from gravity data. Black dashed lines are interpretations by Cook et al. (1964) and white lines are faults interpreted from new gravity data collected in 2011. In either case, a graben-bounding fault, with displacement down to the west, is located between wells SS1 and AMF1. Figure 4.4-3 shows a simplified cross section [adapted from Cook et al. (1964) with the gamma logs of each well plotted alongside the well. Because the logs are not directly comparable (the log of SS1 was acquired two decades before that of AMF1 with a less advanced set of logging tools that recorded different units of gamma activity), their gamma logs were each scaled between 0 and 1 . When plotted this way, they show similar stratigraphic relationships. They each contain a $600 \mathrm{ft}$ $(180 \mathrm{~m})$ thick, double-peaked layer of sediments with a high gamma signature. In well AMF1, that unit is close to the surface (extending down to a depth of about 1100ft), but in SS1 it is displaced downward by almost $1000 \mathrm{ft}$. In Figure 4.4-3, this downward displacement is interpreted to occur on the fault between the two wells, and amounts to about 1000 feet $(\sim 300 \mathrm{~m})$ of downward displacement of the block in which SS1 occurs with respect to that in which AMF1 occurs. If the block in which SS1 occurs is tipped to the east, as is common in stepwise faulting 
adjacent to graben in the Great Basin, the displacement on the fault will be even greater. The importance of this correlation is that it is consistent with the sense of offset implied by gravity data and bolsters the interpretation of the structure of the Wendover graben.

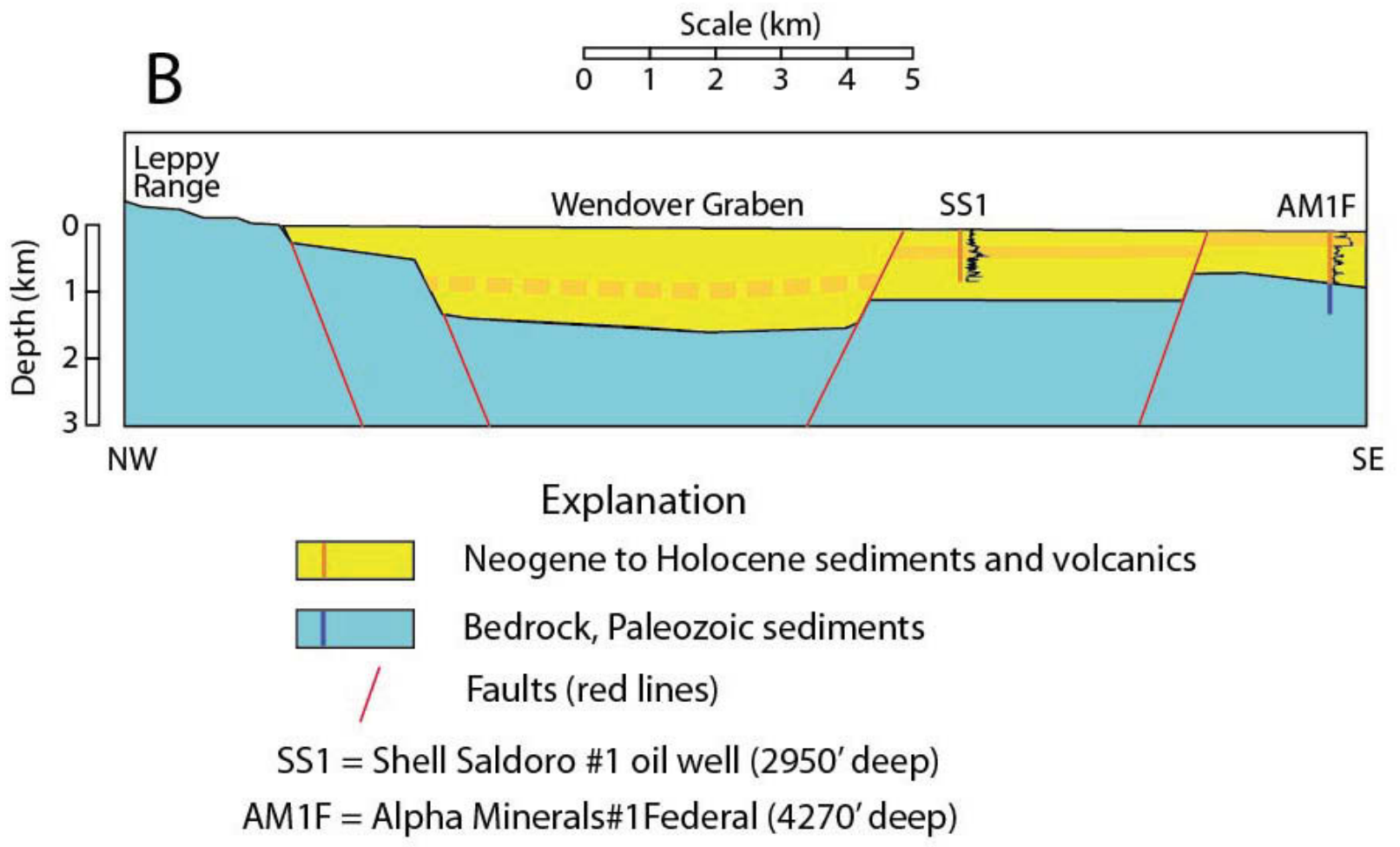

Figure 4.4-3. Generalized NE-SW cross-section through the Wendover graben near wells SS1 and AMF1. Adapted from Cook et al. (1964). The gamma logs of each well are plotted as black traces beside the wells. The layer with the high gamma signature is indicated by the orange band. Inferred position of that layer within the Wendover graben proper is represented by the dashed orange band.

Also in Figure 4.4-3, the high-gamma-signature layer is interpreted, with uncertainty represented by its discontinuous pattern, to be displaced downward even farther by the fault lying just northwest of SS1 into the Wendover graben proper.

\subsection{Field Investigation 5: Sampling and Analysis of Surface Waters and Springs}

Description. Thermal waters discharge at several locations in and adjacent to the West Desert of Utah. Analysis of thermal waters can lead to an understanding of the thermal history of the water and give an indication of the deep reservoir conditions. The principle of chemical geothermometry is based on temperature dependent chemical equilibrium between the water and minerals in the geothermal reservoir and it is assumed that thermal water preserves its chemical composition during its ascent from the reservoir to the surface. Geothermometry is a commonly employed geothermal exploration technique (DiPippo, 2005); however, the assumption of the preservation of water chemistry may not always hold, especially in areas where the waters interact with shallow brine aquifers, resulting in some uncertainty in the calculated results. 
Geothermometry has been performed on nine water samples collected from around the UTTR Focus Area 1; four from the Blue Lake area and five from wells located on the southeast flank of the Silver Island Mountains (see Figures 4.5-1, 4.5-2, and 4.5-3). Appendix E provides a detailed description of the water chemistry study, photos of the sampling locations, and the field and laboratory procedures that were implemented.

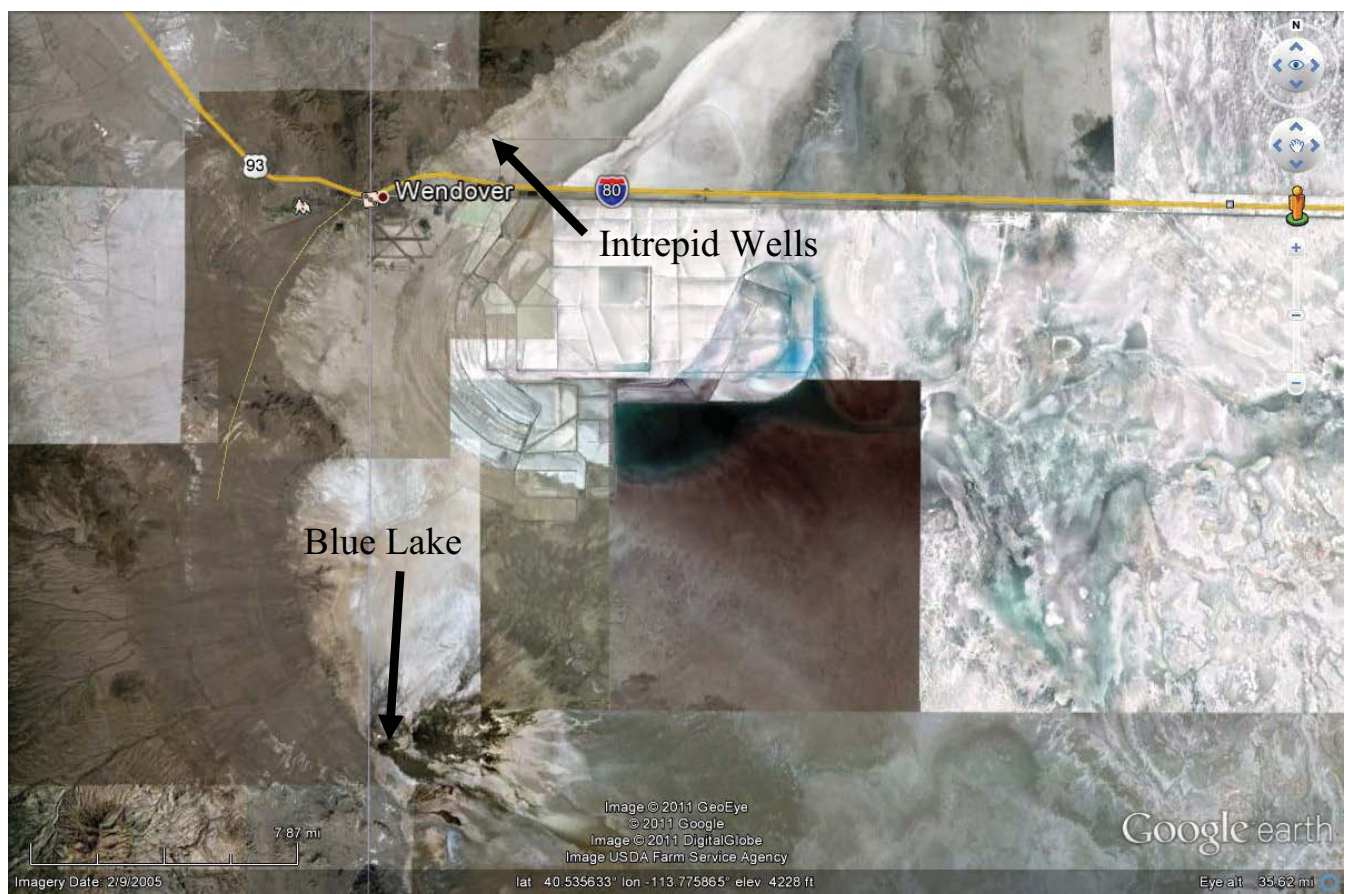

Figure 4.5-1. Satellite image indicating the locations of the Intrepid and Blue Lake sampling areas.

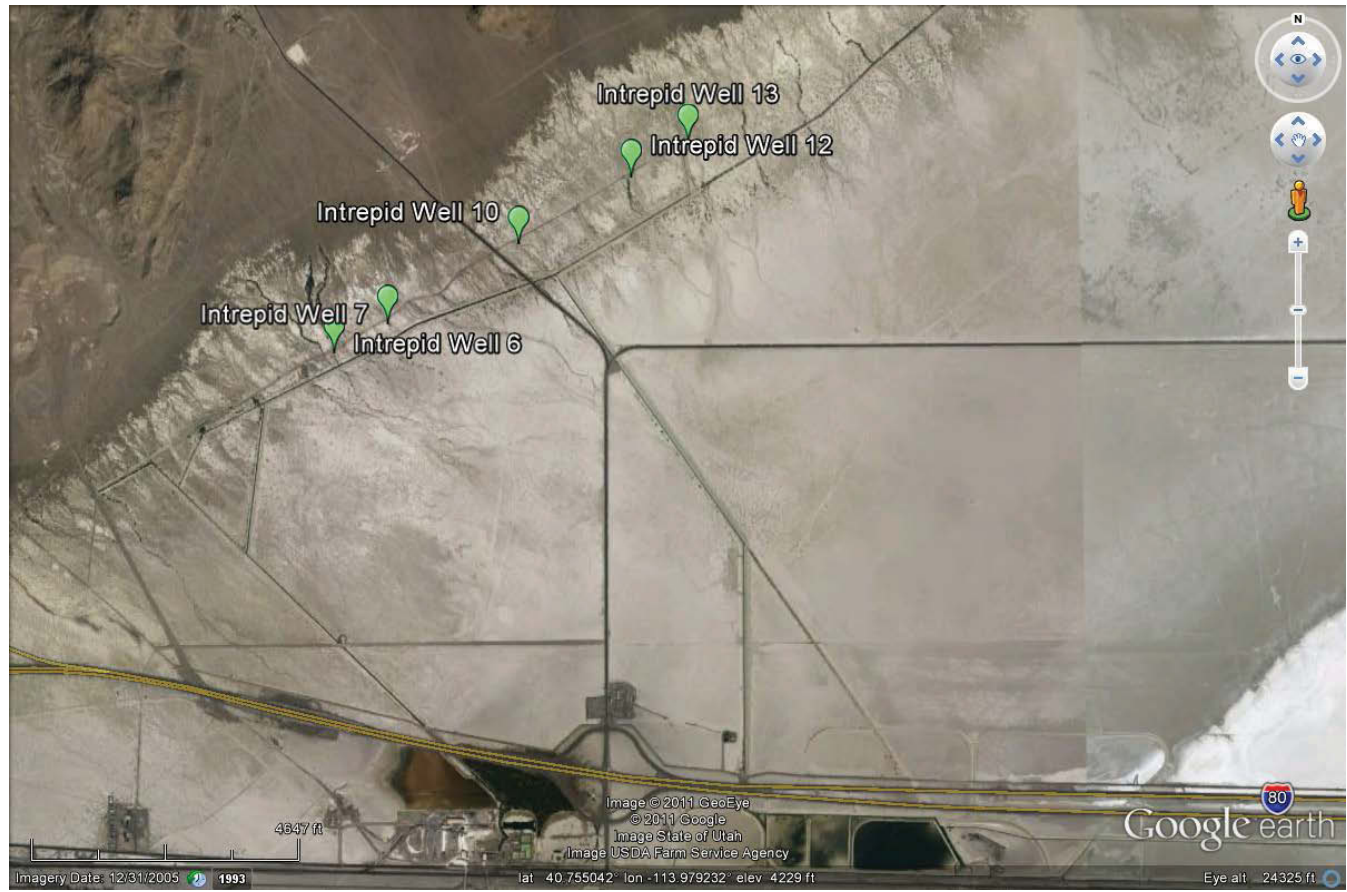

Figure 4.5-2. Water samples were collected from wells 6, 7, 10, 12 and 13, located adjacent to the southeast flank of the Silver Island Mountains. 


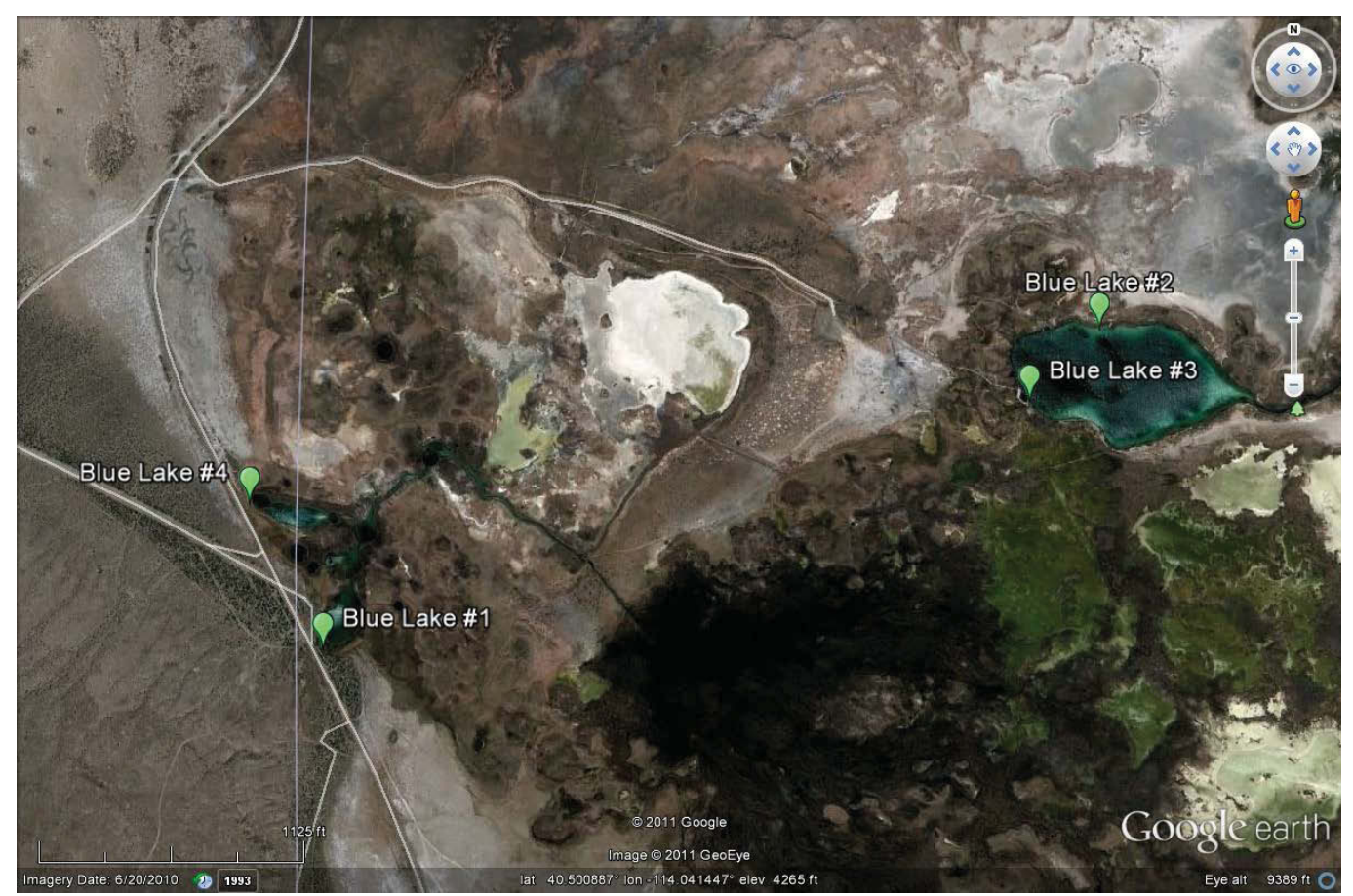

Figure 4.5-3. Satellite image of the Blue Lake area showing the locations of the four samples collected for chemical analyses.

Results. The results of the chemical analyses are presented in Table 4.5-1. The samples were analyzed for major, minor and several trace elements using standard chemical techniques by Thermochem Inc. in Santa Rosa, CA. The analytical results are included in Appendix E. All of the waters are $\mathrm{NaCl}$ in composition with minor $\mathrm{HCO}_{3}$ and $\mathrm{SO}_{4}$. Waters from the Blue Lake area display significantly lower salinities than those from the Intrepid wells on the southwest flank of the Silver Island Range although the measured temperatures of the waters are similar, as shown in Table 4.5-1. Total dissolved solid contents of the Blue Lake waters range from approximately $5000-5500 \mathrm{mg} / \mathrm{L}$, whereas those from the Intrepid wells range from 8000-12500 mg/L. Figures 4.5-4 and 4.5-5 show the relationship between $\mathrm{Na}$ and $\mathrm{Cl}$ and it suggests that the well waters from wells IW-6, IW-7, IW-13, and IW-10 could represent mixtures of water from IW-12 and Blue Lake waters. The very high $\mathrm{Cl}$ contents of the Intrepid well waters suggests that these waters have interacted with salt deposits present in the Bonneville Salt Flats of the west desert. Because of the potential interactions with salt deposits, and their effects on the compositions of the waters, the following discussion is focused on waters from the Blue Lake area, which are more likely to reflect less interaction with the salt deposits. 
Table 4.5.1. Compositions, measured and geothermometer temperatures of Blue Lake (BL) area and Intrepid (IW) well waters. Analytical values in $\mathrm{mg} / \mathrm{L}$. See Appendix E for laboratory analytical sheet for each sample.

\begin{tabular}{|c|c|c|c|c|c|c|c|c|c|c|c|c|c|c|c|c|c|c|}
\hline \multirow{2}{*}{$\begin{array}{c}\text { Sample } \\
\text { Name }\end{array}$} & \multirow[b]{2}{*}{$\begin{array}{l}\text { Temp } \\
\left({ }^{\circ} \mathbf{C}\right)\end{array}$} & \multirow[b]{2}{*}{$\begin{array}{c}\text { UTM }^{\#} \\
\text { East }\end{array}$} & \multirow[b]{2}{*}{$\begin{array}{l}\text { UTM }^{*} \\
\text { North }\end{array}$} & \multirow[b]{2}{*}{ pH } & \multirow[b]{2}{*}{$\mathbf{L i}$} & \multirow[b]{2}{*}{$\mathbf{N a}$} & \multirow[b]{2}{*}{$\mathbf{K}$} & \multirow[b]{2}{*}{$\mathrm{Ca}$} & \multirow[b]{2}{*}{ Mg } & \multirow[b]{2}{*}{$\mathrm{SiO}_{2}$} & \multirow[b]{2}{*}{ Cl } & \multirow[b]{2}{*}{$\mathrm{SO}_{4}$} & \multirow[b]{2}{*}{$\mathrm{HCO}_{3}$} & \multirow[b]{2}{*}{$\mathbf{N H}_{4}$} & \multirow[b]{2}{*}{$\mathbf{R b}$} & \multicolumn{3}{|c|}{$\begin{array}{c}\text { Geothermometer } \\
\text { Temperatures }\end{array}$} \\
\hline & & & & & & & & & & & & & & & & $\begin{array}{l}\text { Chal } \\
\left({ }^{\circ} \mathrm{C}\right)\end{array}$ & $\begin{array}{c}\mathrm{K} / \mathrm{Mg} \\
\left({ }^{\circ} \mathrm{C}\right)\end{array}$ & $\begin{array}{l}\text { Anhy } \\
\left({ }^{\circ} \mathrm{C}\right)\end{array}$ \\
\hline BL1 & 29.2 & 750399 & 4487310 & 6.65 & 1.6 & 1640 & 109 & 156 & 49.2 & 25 & 2780 & 256 & 313 & 0.2 & 0.54 & $40^{\circ}$ & $108^{\circ}$ & $139^{\circ}$ \\
\hline BL2 & 28 & 751442 & 4487777 & 6.84 & 1.67 & 1720 & 115 & 158 & 54.7 & 26 & 2810 & 280 & 311 & -0.2 & 0.58 & $42^{\circ}$ & $108^{\circ}$ & $138^{\circ}$ \\
\hline BL3 & 27.2 & 751350 & 4487676 & 6.97 & 1.63 & 1700 & 120 & 149 & 47.2 & 30 & 2840 & 269 & 314 & 0.3 & 0.56 & $48^{\circ}$ & $111^{\circ}$ & $140^{\circ}$ \\
\hline BL4 & 27.8 & 750292 & 4487504 & 6.95 & 1.59 & 1550 & 107 & 152 & 43.8 & 28 & 2550 & 250 & 312 & -0.2 & 0.56 & $45^{\circ}$ & $109^{\circ}$ & $139^{\circ}$ \\
\hline IW6 & 32.8 & 247849 & 4516657 & 6.87 & 1.57 & 2730 & 126 & 134 & 88.7 & 39 & 4350 & 399 & 203 & 0.2 & 0.25 & & & \\
\hline IW7 & 31.3 & 248138 & 4516802 & 6.93 & 1.61 & 2840 & 139 & 143 & 97.9 & 41 & 4630 & 384 & 199 & -0.2 & 0.27 & & & \\
\hline IW10 & 25.8 & 248845 & 4517193 & 7 & 1.93 & 3690 & 172 & 195 & 142 & 37 & 6440 & 460 & 161 & 0.6 & 0.24 & & & \\
\hline IW12 & 27.3 & 249453 & 4517523 & 7.16 & 2.16 & 4160 & 183 & 253 & 193 & 30 & 7100 & 477 & 167 & 0.5 & 0.25 & & & \\
\hline IW13 & 26.8 & 249761 & 4517698 & 7.36 & 1.52 & 2620 & 121 & 141 & 107 & 36 & 4300 & 308 & 182 & 0.3 & 0.17 & & & \\
\hline
\end{tabular}

\# - UTM Zone 11; * - UTM Zone 12; negative values indicate analytical value less than the detection limit.

As $=\leq 0.01$ (see Appendix E for analytical values); $\mathrm{Cs}=-0.1$; Carbonate Alkalinity (as HCO3-) $=-2$. 


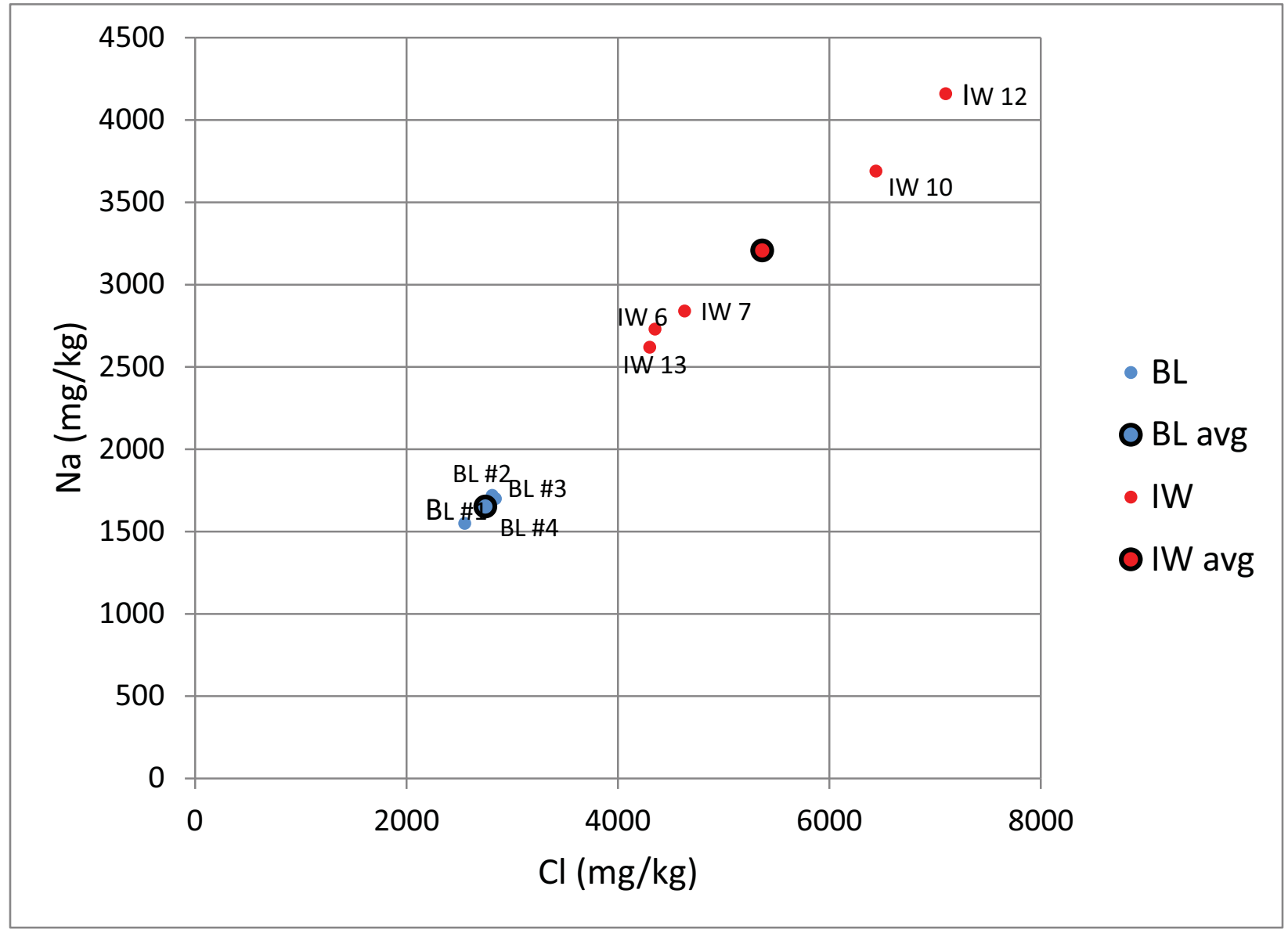

Figure 4.5-4. Relationship between $\mathrm{Na}$ and $\mathrm{Cl}$ in the Blue Lake (BL) and Intrepid wells (IW). Waters from the Intrepid wells IW6, IW7, IW13, and IW10 could represent mixtures of water from IW12 and Blue Lake waters.

A significant feature of the Blue Lake waters is their relatively high $\mathrm{Ca}$ and $\mathrm{Mg}$ contents and $\mathrm{Ca} / \mathrm{Mg}$ ratios near 3. High contents of these cations are typical of carbonate reservoirs. Langmuir (1971) suggested that $\mathrm{Ca} / \mathrm{Mg}$ ratios $>3.0$ indicate interactions with limestones. Ratios between 1.5 and 3.0 can indicate the presence of dolomite beds with a dominantly limestone reservoir whereas ratios $<1.5$ implies interactions with reservoirs consisting mainly of dolomite. Based on the $\mathrm{Ca} / \mathrm{Mg}$ ratios of the Blue Lake waters we suggest that the reservoir rocks consist primarily of limestone with interbedded dolomite beneath the cover of Tertiary and Quarternary sediments and volcanic rocks. 


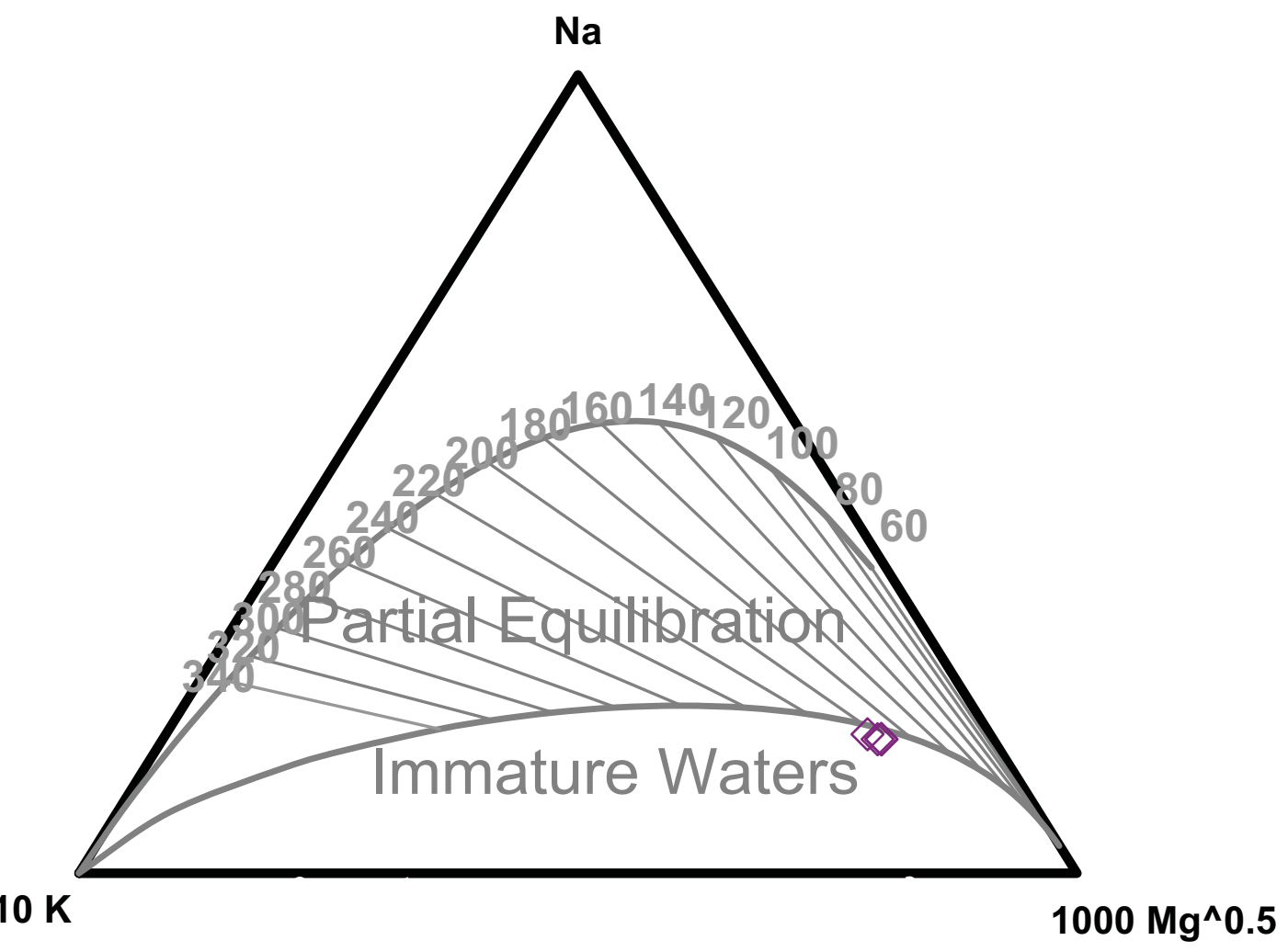

Figure 4.5-5. K-Na-Mg plot of Blue Lake area waters. The samples group at the lower boundary of the region where partial equilibration with the rock is expected.

Figure 4.5.5 shows the K-Na-Mg relationships for the Blue Lake area waters. These waters plot near the base of the region of partial equilibration. Giggenbach (1991) suggested that both silica and $\mathrm{K} / \mathrm{Mg}$ geothermometers (Giggenbach, 1991) could be applied to samples plotting in this portion of the diagram, although with caution. Temperatures calculated based on the $\mathrm{K} / \mathrm{Mg}$ geothermometer yield values of $108-111^{\circ} \mathrm{C}$. The chalcedony geothermometer, the most appropriate silica geothermometer for low temperature waters, in contrast yields temperatures of $40-48^{\circ} \mathrm{C}$. Although it cannot be demonstrated that mixing with low silica waters has occurred, the low measured temperatures of these waters and the significantly higher temperatures encountered the Intrepid Deep Brine Well DB-3 (Turk, 1973) suggests that dilution is a likely explanation for the low calculated values.

The anhydrite geothermometer is based on equilibria between the fluid and anhydrite. It is calculated from the $\mathrm{Ca}$ and SO 4 contents of the thermal fluids and assumes the presence of anhydrite in the reservoir. Although the presence of anhydrite was not noted on the well logs of nearby wells, gypsum was observed. Anhydrite is a common mineral in carbonate terrains and is likely to be present. Temperatures calculated from the anhydrite geothermometer range from $138-140^{\circ} \mathrm{C}$. 
Water from Blue Lakes was analyzed for tritium by a laboratory at the University of Utah. Results showed a value of $0.34 \mathrm{TU}$ (tritium units). Samples that have 0.020 or less TU are classified as pre-1952 (pre-bomb atmospheric nuclear testing). The Blues Lakes tritium concentration is categorized as mixed water (pre- and post-1952), with most of the water being pre-bomb. Therefore, most of the water in Blue Lakes is considered "old" water that has been isolated from the atmosphere in a deep ground water flow pathway.

\section{INTERPRETATION OF NEW DATA AND CONCEPTUAL MODEL}

As described in the preliminary INL report (Smith et al, 2011), there are a variety of different geothermal explorations models for basin and range deep circulation geothermal systems. These "conceptual" models are used to define the salient features of the geology, temperature regimes, and hydrogeology that must be present in order for a viable geothermal exploration target to exist. Conceptual geothermal models all recognize that a geothermal system with commercial potential must have sufficient heat, water, and permeability. Neither is sufficient on its own; instead, it is the coincident occurrence of multiple characteristics that contribute to the existence of a geothermal reservoir capable of electrical generation. In this section we summarize the results from the 2011 field studies and assemble a viable conceptual model for a geothermal prospect on the UTTR-S. The purpose of the conceptual model is to assemble the best available data to identify the most likely place to drill to evaluate the geothermal resource.

\subsection{Interpretative Synthesis of Results for the 2011 Field Activities}

The information acquired from the five field activities conducted in 2011 are integral to development of a conceptual model of potential geothermal activity beneath Focus Area 1 of the UTTR-S. The conceptual model presented at the end of this section integrates the regional information assembled in the preliminary report (Smith, et al, 2011) with the 2011 field data to develop an interpretation of the subsurface specific to geothermal resource potential for Focus Area 1. This section presents an interpretative summary of the most important new information from the field activities that are relevant to development of the conceptual model of the geothermal system, which is then followed by a presentation of the conceptual model.

The detailed gravity survey provides some of the most crucial information for defining the locations and depths of subsurface structures. The horizontal gravity gradient map, as shown in Figure 4.1-6, and the various contour maps of the gravity data in Figures 4.1-4 and 4.1-5 provide important constraints on the locations of buried faults that bound the graben system. The shape and magnitude of the negative gravity anomaly show that the Wendover graben as defined in earlier gravity studies by others and confirmed by the 2011 work, extends southwestward from the area of Interstate Highway 80, across the lands of Intrepid into the northwest corner of Focus Area 1 on the UTTR-S, ending against the low hills west of the Blue Lakes area. The negative gravity anomaly also suggests a second graben that intersects the southern end of the Wendover graben at nearly right angles and extends northwestward to the flank of the Toano-Goschute range (see Figure 4.4-1). Modeling of the negative gravity anomaly and various depictions of the anomaly (see Figures 4.1-4 through 4.1-7) provide important constraints on subsurface geometry. The depth model (see Figure 4.1-7) shows that the deepest part of the Wendover graben is at its south end, just west of Focus Area 1, and that the northwest-trending graben intersects the Wendover graben in that same area. The depth model also shows that the deepest part of the graben is in the range of 2 to $4 \mathrm{~km}$ beneath the surface, depending on the estimated density 
contrast between the sediments filling the graben and the bedrock beneath and adjacent to the graben. All of the maps shown in the above figures, and especially that shown in Figure 4.1-7, show that the Wendover graben curves from a northeast-trend near I-80, to a northerly trend as it crosses the Intrepid lands, and back to a northeast trend near Focus Area 1. That curving shape can be accommodated either by curving faults or by left-stepping segmented faults. Because the gravity survey of 2011 was designed to cover the entire Focus Area 1 and surrounding areas and to reveal the basic structure of the Wendover graben south of I-80, it does not provide sufficient detail to distinguish these features. It is possible that acquisition of additional, more detailed gravity data, focused in the area northeast of Blue Lakes Springs could discriminate between these possible interpretations. Additional lines of gravity stations in the northwest corner of Focus Area 1 could be acquired to help resolve fine details of the structure there (see Section 6).

The borehole temperature logging by UGS personnel (Blackett et al., 2011; Appendix B of this report) of existing Intrepid wells provide other important keys to conceptual model development. The most important results are corroboration of the temperatures reported by Turk (1973) and the determination of geothermal gradients in the area (see section 4.2). Confidence in the Turk (1973) data allows contouring of temperatures in the depth range of 300-500 $\mathrm{m}$ and leads to a rationale for the high temperatures reported for DBW-3, as discussed in section 5.2.

The thermal gradients measured for sections of the wells logged in 2011 (see Figure 4.2-2) range from $40^{\circ} \mathrm{C} / \mathrm{km}$ for well DBW-14A to $70^{\circ} \mathrm{C} / \mathrm{km}$ for well DBW-17. Continuation of the $70^{\circ} \mathrm{C} / \mathrm{km}$ for well DBW-17 results in a temperature of about $85^{\circ} \mathrm{C}$ at $1 \mathrm{~km}$ and $155^{\circ} \mathrm{C}$ at $2 \mathrm{~km}$ depth. Even the relatively modest gradient of $57^{\circ} \mathrm{C} / \mathrm{km}$ for well DBW-8 results in a temperature of over $65^{\circ} \mathrm{C}$ at $1 \mathrm{~km}$ and over $120^{\circ} \mathrm{C}$ at $2 \mathrm{~km}$ depth. With sufficient water flow from a well, these temperatures are within the range necessary for binary generation of electrical power.

Figure 5.1-1 is a summary of all available temperature data for Focus Area 1 and vicinity (Blackett et al. 2011, Appendix B of this report; Moore et al., 2011, Appendix E of this report; Henrickson and Chapman, 2002; and Brinton et al., 2011, Appendix D of this report). This figure emphasizes the importance of the reported $88^{\circ} \mathrm{C}$ temperature in DBW-3 because it suggests much higher temperature gradients exist in the area than those determined for the deep brine wells logged in 2011. The similarity and isothermal nature of the first $100 \mathrm{~m}$ below the water table for the deep brine well logs suggests that a shallow aquifer with temperature of around $15^{\circ} \mathrm{C}$ masks the higher gradients that occur at depth. The temperature measured in Well DBW-3 was taken at a single point representative of a depth of about $500 \mathrm{M}$. Extrapolating the $88^{\circ} \mathrm{C}$ taken at $500 \mathrm{M}$ in DBW-3 to the shallow isothermal $15^{\circ} \mathrm{C}$ layer or to the deep temperature curve of DBW-17, indicates gradients of $170-265^{\circ} \mathrm{C} / \mathrm{km}$, respectively. A lower, but still reasonable geothermal gradient is around $120^{\circ} \mathrm{C} / \mathrm{km}$, which is defined by assuming a surface temperature of about $30^{\circ} \mathrm{C}$, similar to the temperature of Blue Lakes Springs. These hypothetical thermal gradients are depicted in Figure 5.1-1 with dashed lines. In all cases, the rapid rise in temperature with depth in the vicinity of DBW-3 suggests local upwelling of warm waters, possibly on the eastern boundary fault system of the Wendover graben (see section 5.2 and Figure 5.2-3). In areas more distal to Focus Area 1, the geothermal gradient is known to be lower. For instance, the corrected bottom hole temperatures of the nearby petroleum exploration wells, SS1 and AMF1, indicate only modest gradients of around $30-50^{\circ} \mathrm{C} / \mathrm{km}$ (see Figure $5.1-1$ ) Those gradients probably represent the background subsurface temperature distribution away from faults and other features that influence the deep circulation of thermal waters. 


\section{Summary of Temperature Data Near Focus Area 1}

Temperature, ${ }^{\circ} \mathrm{C}$

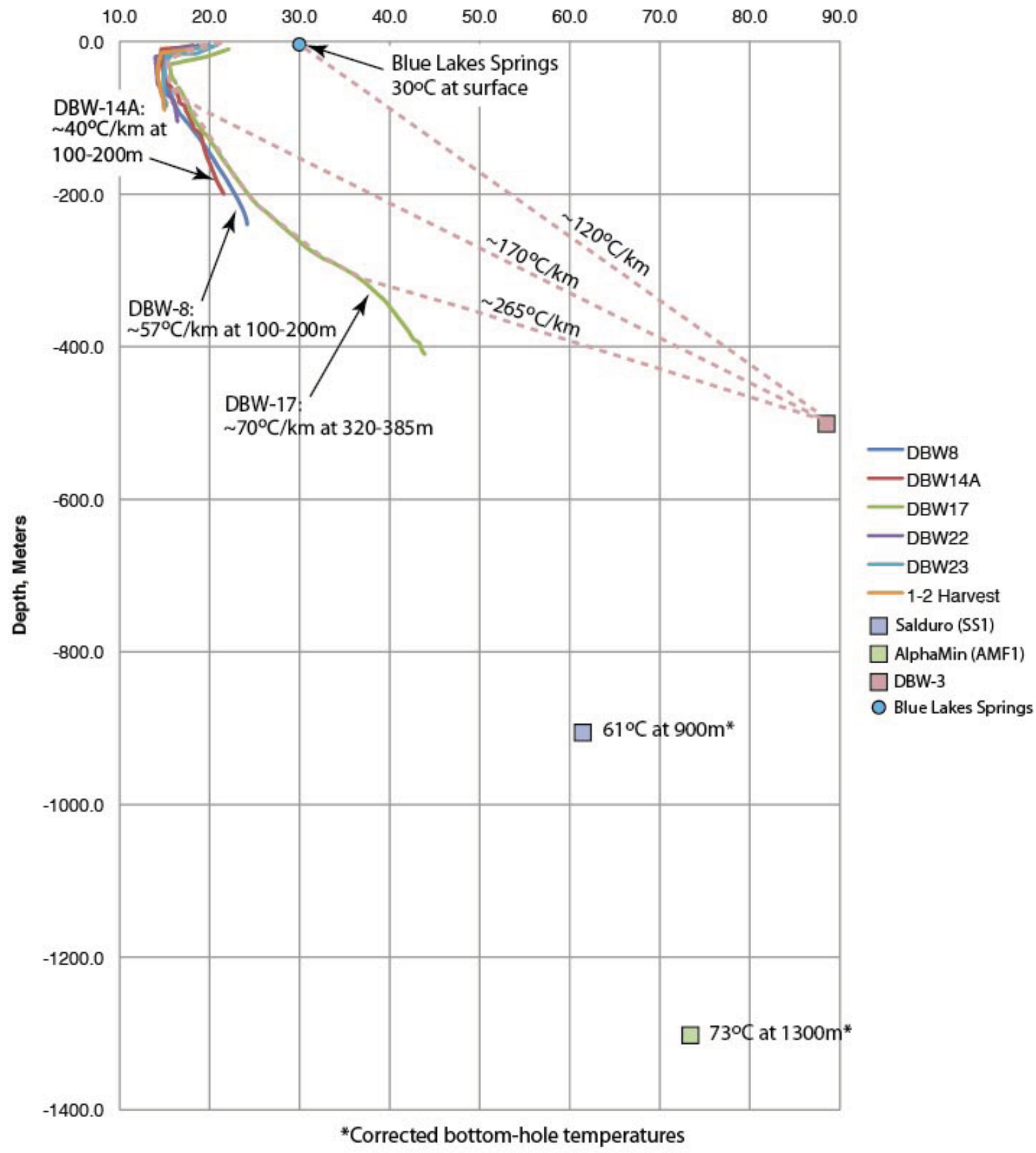

Figure 5.1-1. Temperature-Depth plot of all the available temperature data for areas near Focus Area 1. 
The lineament study (see section 4.3) identified several northeast-trending lineaments whose locations coincide or nearly coincide with subsurface faults interpreted from gravity data (see Figures 4.3-1 and 4.3-2). Also, some minor northwest-trending lineaments were mapped. The location and trend of surface lineaments bolster the interpretation of fault locations and provide further support that bedrock faults have been active so recently that they penetrate to land surface. On-the-ground field inspections of the lineaments are also important because they show that some of the lineaments extend into areas of nearby bedrock that are marked by zones of broken rock, veins of calcite, and other evidence of faulting. This means that the tectonic movements causing the surface lineaments are deep seated, penetrate bedrock and may extend to depths where ambient geothermal temperatures are relatively hot. These are indicators that conditions may exist that are favorable for geothermal development.

The analysis of borehole geophysical logs of petroleum exploration wells (see section 4.4) lead to two conclusions relevant to the conceptual model. First, the low matrix porosities and permeabilities of bedrock calculated from density and sonic logs of wells near Focus Area 1 are only part of the story. They reveal the lower limits of permeability and porosity for the bedrock units because they are based on uniform density and sonic velocity for the small volumes of rock within a few feet of the logged wells. We know from other studies that, at the regional scale, these same lower Paleozoic limestones and dolomites host regional aquifers throughout the Great Basin with permeabilities sufficient to allow movement of groundwater between basins (Heilweil and Brooks, 2010). This is because they have been subjected to several different periods of tectonic deformation, including Mesozoic and early Cenozoic thrust faulting and folding, and late Cenozoic extension and normal faulting. These tectonic events produced both distinct thrust and normal faults and distributed fracturing of the rocks over large areas. In some areas the rocks have also been subject to dissolution, producing voids, cavities, and caverns. Additional evidence of significant permeability comes from the sampling and analysis of the waters from Blue Lakes and Mosquito Willey's springs (see Section 4.5). They last equilibrated with these same lower Paleozoic carbonate rocks and without significant bedrock permeability those waters would not be able to move through the basement rocks and upward along fault zones and to constantly feed large-volume springs. Therefore, despite the calculated low matrix permeabilites, there is significant potential for a productive geothermal system near Focus Area 1. Such a system would take advantage of fracture permeability along fault zones augmented by distributed fracture permeability of the basement rock units.

The second important conclusion from the borehole geophysical log investigation is the correlation of Cenozoic sedimentary units between wells AMF1 and SS1, using gamma logs. This correlation suggests a basin-ward displacement of about $1000 \mathrm{ft}(\sim 300 \mathrm{~m})$, down-to-thewest, across an inferred fault between the two wells (see Figure 4.4-3). This is consistent with sense of offset indicated by the gravity data and supports the concept that graben-bounding faults in the bedrock have been continuously active during Cenozoic time and extend upward to the surface through the Cenozoic sediments. If so, they may provide the pathways for thermal waters to reach springs such as Blue Lakes and Mosquito Willey's springs, and to generate the high temperatures reported in some of the Intrepid wells.

The final investigation, sampling and analysis of surface waters and springs, provides further constraints on the conceptual model. Importantly, the measured temperatures in Blue Lakes springs $\left(\sim 30^{\circ} \mathrm{C}\right)$ corroborate temperatures reported in the literature (Blackett and Wakefield, 2002). The chemical analysis of spring waters show that the Blue Lakes Springs waters are much 
less saline than those from flowing wells and springs farther north in the Bonneville Salt Flats area. More importantly, the chemistry of Blue Lakes Springs waters suggest that they last equilibrated with Paleozoic limestones and dolomites beneath the Cenozoic sediments. Also, use of appropriate chemical geothermometric calculations suggest that the temperatures at the depth of origin can be as high as $140^{\circ} \mathrm{C}$.

\subsection{Interpretation and Geometric Constructions}

The summary discussion in the previous section helps guide development of the conceptual model. In an effort further define and constrain the conceptual model, scaled cross sections were constructed through the Wendover graben system. This subsection describes a rational interpretation of the subsurface geometry and temperature distribution in and near the graben system and Focus Area 1.

Cross sections were located and oriented to cross the Wendover graben at nearly right angles and to pass through important surface features (see Figure 5.2-1). Cross section B (XC-B) corresponds to the cross section presented in Cook et al. (1964). That cross section has been presented in Figure 4.4-3 with interpretations from the geophysical logs from two petroleum exploration wells included. In the cross section, the two exploration wells (SS1 and AMF1) are projected to the line of the section with the interpreted $300 \mathrm{~m}$ offset of the high-gamma unit of the Cenozoic sediments shown. Cross Section XC-B illustrates the basic structure of the graben at about the latitude of Interstate Highway 80. The graben is flanked on each side by two faults, each of which progressively drops the bedrock to a deeper level. At that latitude, the graben is probably in the range of $1.5-2 \mathrm{~km}$ deep.

Cross section $\mathrm{C}(\mathrm{XC}-\mathrm{C})$ was constructed to illustrate the structure at the deepest part of the Wendover graben (see Figure 5.2-2). This section also shows our interpretation of the northwesttrending graben and its intersection with the Wendover graben. The depth model generated from the gravity data (see Figure 4.1-7) shows that the NW-trending graben progresses from a deep area at its NW end, through a shallow area in its mid-section, to the deep area at its intersection with the Wendover graben. We have interpreted the shallow midsection to be flanked by two faults making a small horst, but it could just as reasonably be an up-warp in the floor of the graben (due to this uncertainty the faults are not depicted in the base map). The deepest part of the graben system is located at the intersection of the NW trending graben and the Wendover Graben, This is interpreted to be a fault-bounded block with a depth to bedrock of up to $4 \mathrm{~km}$. The positions of the faults are defined by the steepest gradients in contoured maps of the gravity data (see Figures 4.1-4 and 4.1-6). Fault dips of 50-60 degrees, typical of graben-bounding faults throughout the Great Basin, are depicted in the cross-section. The cross-section also illustrates a possible rationale for the location of the Blue Lakes Springs. The southeast boundary fault projects to the surface in the vicinity of the springs, providing a permeable zone that may carry rising geothermal waters to the springs. Mosquito Willey's springs lie farther to the southeast, but a prominent lineament passes through that spring system, suggesting a similar fault control, but in that case the fault displacement is so small that it does not affect the gravity signature. 


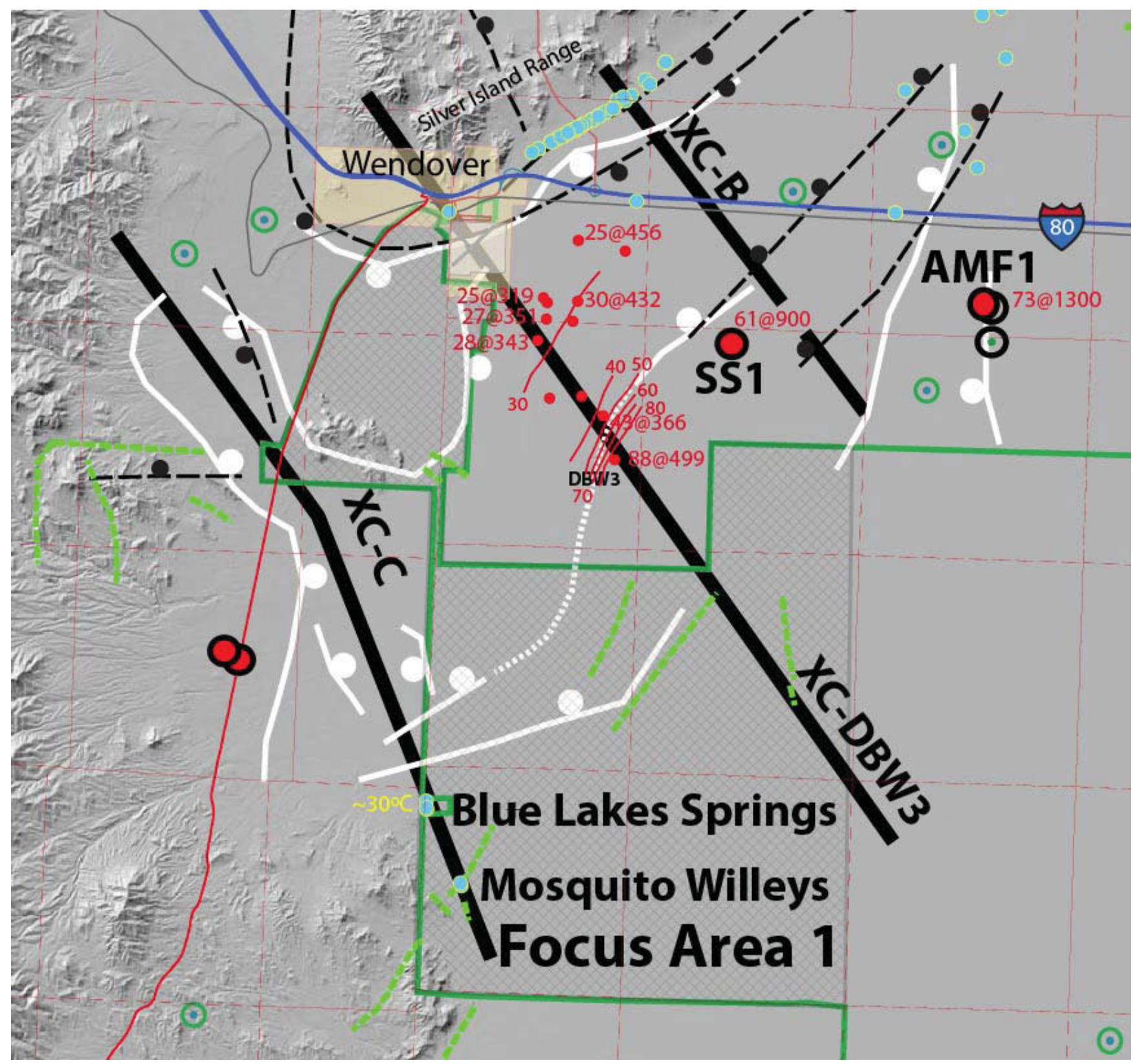

Figure 5.2-1. Locations of cross sections constructed to illustrate geometry of subsurface structure and temperature distributions. Also shown in this figure are: lineaments (dashed green lines); earthquake epicenters (green circles with blue dot in the middle); springs (light green circles with blue fill); faults interpreted from gravity data (heavy white lines with ball on downthrown side); petroleum exploration wells (heavy black circles with red fill); deep brine wells reported by Turk, 1973 (red dots); temperature contours based on temperatures reported by Turk, 1973 (red lines with temperature indicated $-30-80^{\circ} \mathrm{C}$ at 300-500 m depth). UTTR-S outlined in green; Focus Area 1 indicated by light cross-hatch.

Cross Section DBW-3 (XC-DBW3) was constructed to illustrate the potential geometry of the fault system that could account for the temperature distribution near Deep Brine Well 3, which has a reported temperature of $88^{\circ} \mathrm{C}$ at about $500 \mathrm{~m}$ depth (Turk, 1973). In this cross section the depth of the graben floor is in the range of $2-3 \mathrm{~km}$. Although the position of the bounding fault on the southeast side of the graben is not tightly controlled, the data suggest that fault lies close to DBW-3 and we have projected it to the surface near DBW-3 (see Figure 5.2-3). The Turk (1973) temperature data is contoured in the depth range of $300-500 \mathrm{~m}$ in Figure $5.2-1$. The 
distribution of reported temperatures allows a range of orientations of contour lines. For this interpretation, we have chosen to contour the data parallel to our interpreted trend of the bounding fault. In the cross section (see Figure 5.2-3) a rational explanation for the high temperature reported for DBW-3 is revealed. Geothermal waters enter the fault zone at depth (white arrow) and travel up the fault through the bedrock and overlying Cenozoic sediments to shallow depths, causing elevated temperatures at relatively shallow depths as measured in Intrepid's deep brine wells. The temperature contours northwest of DBW-3 on the cross section are constrained by Turk's near surface temperature data (300-500m depth). Southeast of DBW-3 the temperatures are interpreted to likewise diminish away from the well and from the projected fault.

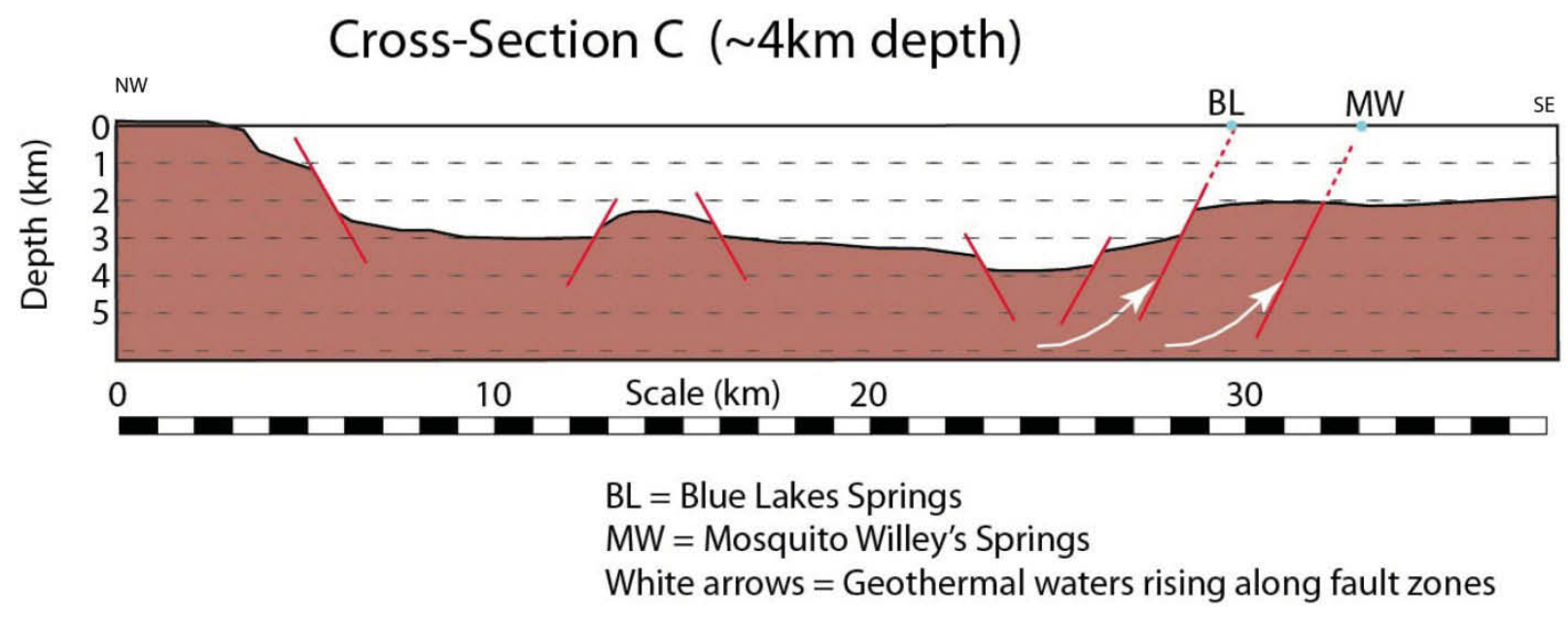

Figure 5.2-2. Cross-section C through the deepest part of the Wendover graben.

It should be noted that the curving, dashed portion of the fault in map view (see Figure 5.0-1) accommodates the shape of the Wendover graben as revealed by the gravity data, as shown in Figures 4.1-4, 4.1-5, and 4.1-7. These figures show that the deepest gravity lows and the modeled depth, define a curving graben, whose trend swings from northeast near I-80 to nearly north-south across the Intrepid area, and back to northeast in the northwestern corner of Focus Area 1. That graben shape can also be accommodated by a series of two or more left-stepping fault segments between the Blue Lakes area and DBW-3. In that case, the broken zone that allows upwelling of the geothermal waters would be broader, potentially much broader, than that shown in Figure 5.2-3. Also, it could be discontinuous, with water movement focused near segment ends, in broken zones between segment ends, or confined within each segment. 


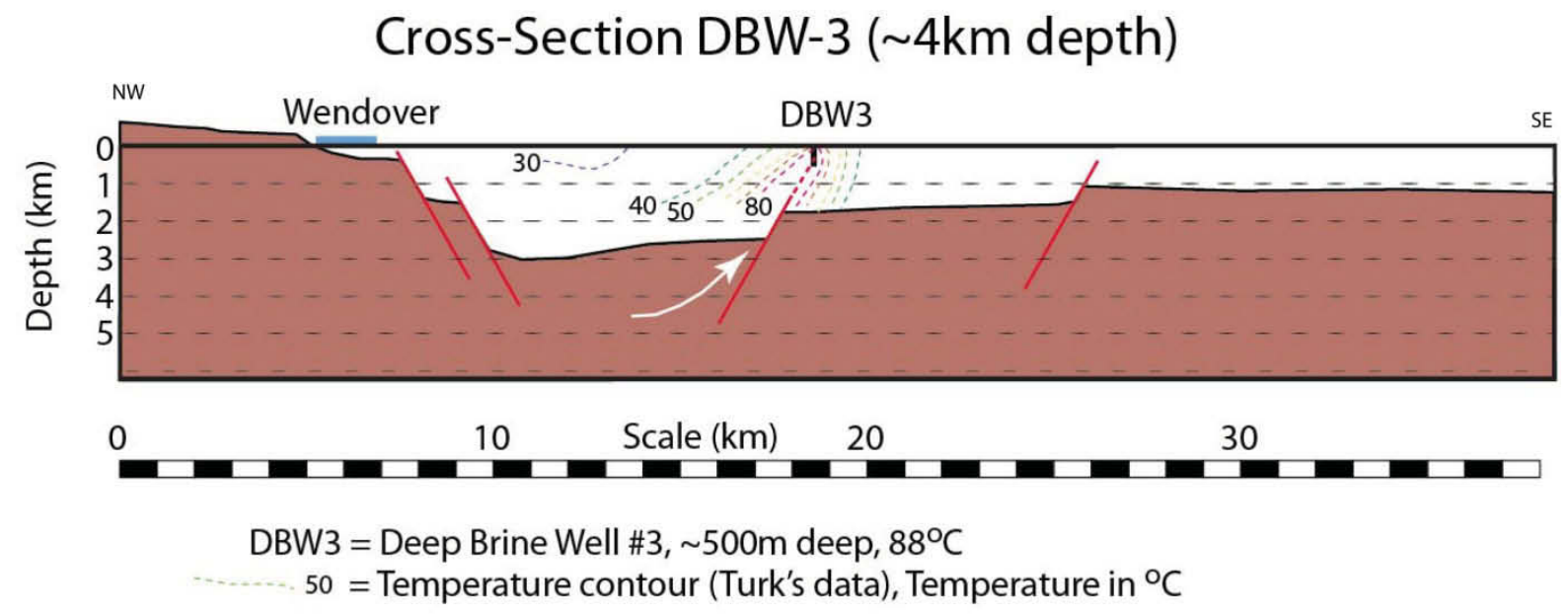

Figure 5.2-3. Cross-section DBW-3, through Intrepid's Deep Brine Well \#3. As in Cross-section C, the white arrow indicates upflow of geothermal waters.

There is another assumption that influences interpretations of the geometry of subsurface structures related to the Wendover graben and introduces additional uncertainties. The depth model derived from the gravity data (see Section 4.1 and Figure 4.1-7) assumes a uniform density (and thus constant density contrast) for both bedrock and overlying basin-fill sediments. The subsurface geometry resulting from this assumption can be affected by density heterogeneities that are likely to exist in the area. For instance, it is known that two wells in the area (DBW-1 in the Intrepid area and Shell Salduro \#1 both north of Focus Area 1) intersected basaltic rocks near their bottoms. This is important because the high density of basaltic igneous rocks has a strong influence on measured gravity values and their presence in the basin-fill sequence or in the bedrock can strongly affect the interpretation of subsurface structure. For example, it is difficult to explain the large positive gravity anomaly between Blue Lakes Springs and the east boundary of Focus Area 1 (see Figure 4.1-5) by a shallowing of the depth to bedrock because it is higher than that to be expected for outcrop of bedrock. However, it is located in an area where basin-fill sediments occur at the surface and a thick sequence of thick basin-fill sediments is expected. A shallow basalt lava flow or volcanic field buried within the sediments (or a thick one at greater depth) could produce this observed positive gravity anomaly. Because of the locations of the wells where basalt was encountered (DBW-1 and SS1, see Figure 4.2-1) it is possible that such a volcanic unit extends southward into the eastern part of Focus Area 1. It is important to test this idea because the effect on the gravity survey results would be to mask or partially mask the southeastern boundary of the Wendover graben, complicating or changing the structural interpretations shown in Figures 5.2-2 and 5.2-3. For this reason the aeromagnetic survey proposed in Section 6 should be given high priority, probably higher than the in-fill of gravity coverage. If a basaltic unit is present in the basin-fill sediments or in the bedrock, it would be revealed by the aeromagnetic survey because basaltic volcanic rocks are extremely magnetic in addition to being very dense. A similar puzzle exists between Blue Lakes Springs and the bedrock outcrops just to the west and southwest of the springs. A steep gravity gradient is expected, but not observed, between the springs and the outcrops. The proposed in-fill of gravity coverage and the aeromagnetic survey proposed in Section 6 will both help to resolve this problem area. 
The existing temperature, gravity, and thermal spring data suggest that the southeast bounding fault system of the Wendover graben, whether it is a simple curving fault or a series of left-stepping segments, acts as a conduit for rising geothermal waters and is a viable target for exploratory drilling.

\subsection{Conceptual Model}

Conceptual models are basically working hypotheses that tend to evolve with time as new data are obtained. It is not unusual to visualize and simultaneously evaluate more than one conceptual model and, in general, the more sparse the data the greater the number of conceptual models that will fit all of the data. In arriving at our preferred conceptual model we considered data from multiple sources, including the results of the 2011 field activities and analogy to known geothermal areas throughout the Great Basin. Our favored conceptual model is as follows: Faults bounding the southeast margin of the Wendover graben act as conduits for warm waters to move upward from depth to either discharge to springs or to enter shallow water zones. This is evidenced by the Blue Lakes and Mosquito Willey's springs and by the high temperatures reported in Intrepid's Deep Brine Well \#3. The upwelling waters result from the deep circulation of meteoric water through native rocks with elevated temperatures; there is no evidence to support the involvement of young igneous rocks or magma. The Wendover graben hosts a standard Great Basin deep-circulation geothermal system, but its size, depth, maximum temperatures, and volume rates of flow await discovery. Although no age data for the geothermal water exists, analogy to other Great Basin systems suggests that the deep circulation waters are Pleistocene in age, and infiltrated into the subsurface during the most recent high-stands of Lake Bonneville. Current (Holocene) precipitation patterns probably do not contribute significantly to the thermal spring waters discharging at the surface today, but may feed shallow aquifers that mask, or partially mask, the older thermal waters. This is consistent with the tritium data presented and discussed in Section 4.5. This is especially true along the flanks of the Silver Island Range, where runoff from the bedrock infiltrates into the shallow parts of the Cenozoic sediment section.

Because of the high heat flow associated with the Great Basin in general, and the western Great Salt Lake Desert in particular, the circulation of meteoric water to depths of several kilometers is sufficient to raise their temperatures to levels sufficient for electric generation. The recent, through-going faults associated with Basin-and-Range extension are responsible for the occurrence of such systems. The detailed characteristics of the faulting and the thickness and thermal characteristics of the Cenozoic sediments filling the graben will ultimately determine the character of geothermal circulation beneath Focus Area 1. Deep circulation of waters and thick cover of insulating Cenozoic sediments may enhance the potential for high temperatures. The southern end of the Wendover graben, where it is deepest, is the preferred target for further exploration. Also, the necessity for very high permeabilities focuses exploration efforts towards the bounding faults, and any faults that may intersect them, because of the associated potential for enhanced permeability in those areas. The ultimate objective of the exploratory drilling program is to intersect one of the bounding faults, and/or a highly permeable bedrock unit, at depths sufficient to produce large volumes of water warmer than about $100^{\circ} \mathrm{C}$.

The chemical characteristics of waters from Blue Lakes springs, suggesting that they equilibrated at depth with Paleozoic limestones and dolomites at temperatures as high as $140^{\circ} \mathrm{C}$, is consistent with geologic knowledge of the area. Geologic mapping of the mountains just west 
and northwest of Focus Area 1 show that the main rock types are lower Paleozoic carbonate rocks (limestone and dolomite) (Hintze et al., 2000; Stewart and Carlson, 1978; Schneyer, 1990). These same rock types, along with minor occurrences of Neogene rhyolite, andesite, and basalt lavas are likely to be encountered if deep exploration wells are drilled into the bedrock (see Table 5.3-1). Also, basalt lava flows within the basin-fill sequence have been reported in some wells in the area (Turk, 1973; Shell Salduro \#1 well), and could be encountered during future thermal gradient drilling and in deep exploratory drilling in and near Focus Area 1.

Table 5.3-1. Summary of Rocks Exposed in Mountain Ranges West and Northwest of Focus Area 1, and therefore likely to be encountered in deep exploration wells beneath Focus Area 1.

\begin{tabular}{|c|c|c|}
\hline Geologic Era & Geologic Period & Rock Unit \\
\hline Cenozoic & Late Tertiary (Neogene) and Quaternary & Andesite, rhyolite (probably 5-20my old) \\
\hline Mesozoic & Jurassic & Granitic intrusive rocks ( $\sim 140$ my old $)$ \\
\hline \multirow{2}{*}{ Upper Paleozoic } & Permian & $\begin{array}{l}\text { Arcturus Formation (Sandstone with thin beds } \\
\text { of limestone and dolomite). }\end{array}$ \\
\hline & Pennsylvanian/Permian & $\begin{array}{l}\text { Oquirrh Group (thick sequence of sandstones } \\
\text { and limestones). }\end{array}$ \\
\hline \multirow{5}{*}{ Lower Paleozoic } & Mississippian & Chainman Shale \\
\hline & Devonian & $\begin{array}{l}\text { Guilmette Formation (dolomite), Simonson } \\
\text { Dolomite, Sevy Dolomite, and Pilot Shale }\end{array}$ \\
\hline & Silurian & Laketown Dolomite \\
\hline & Ordivician & $\begin{array}{l}\text { Ely Springs Dolomite, Eureka Quartzite, } \\
\text { Crystal Peak Peak Dolomite, Watson Ranch } \\
\text { Quartzite, Lehman Formation, Kanosh Shale, } \\
\text { Juab Limestone, Wah Wah Limestone, } \\
\text { Fillmore Limestone, and House Limestone. }\end{array}$ \\
\hline & Cambrian & $\begin{array}{l}\text { Notch Peak, Orr, Lamb, Weeks, Wah Wah, and } \\
\text { Summit Formations (mostly limestones and } \\
\text { dolomites) }\end{array}$ \\
\hline
\end{tabular}

Significant permeability has been reported in lower Paleozoic carbonates throughout the Great Basin by Heilweil and Brooks, 2011, and they show a great thickness of this lower Paleozoic carbonate aquifer beneath the sediments in the Wendover area (see Figure 5.3-1). In Figure 5.3-1, the lower carbonate aquifer unit (LCAU) is shown by the dark blue color and is given a high probability (heavy dashed vertical line) for providing a hydrologic connection between the Goschute Valley and the Great Salt Lake Desert beneath the Goshute Mountains. Also, enhanced permeability can be associated with basalt lava flows and other volcanic rocks, which commonly have extensive fracture systems and vesicular textures that readily conduct groundwater. 


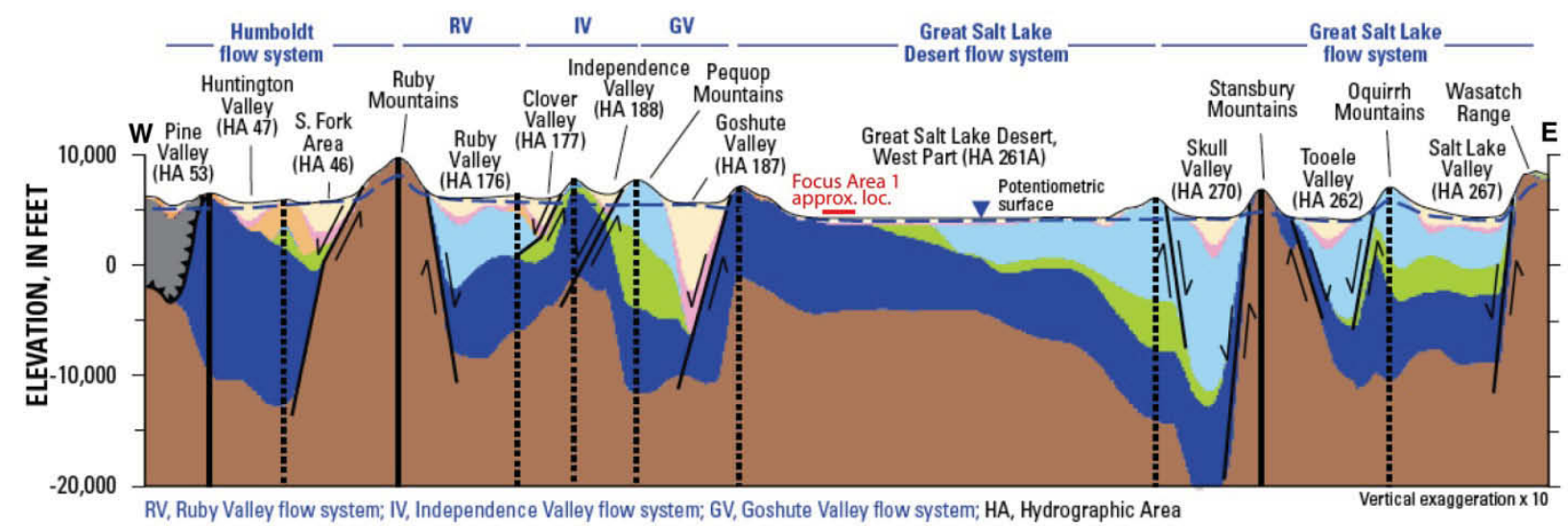

EXPLANATION

Upper basin-fill aquifer unit (UBFAU)

Lower basin-fill aquifer unit (LBFAU)

Volcanic unit (VU)

Thrusted lower carbonate aquifer unit (TLCAU)

Thrusted noncarbonate confining unit (TNCCU)

Upper carbonate aquifer unit (UCAU)

Upper siliciclastic confining unit (USCU)

Lower carbonate aquifer unit (LCAU)

Noncarbonate confining unit (NCCU)

Trv Thrust fault

$\leftrightharpoons$ Fault-Arrows indicate direction of vertical movement on normal faults
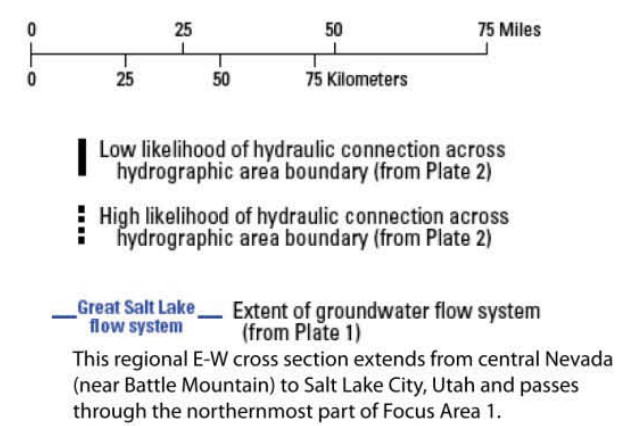

Figure 5.3-1. This regional cross-section extends from central Nevada (near Battle Mountain) to Salt Lake City, UT, and passes through the northernmost part of Focus Area 1. 


\section{RECOMMENDATIONS FOR FURTHER EXPLORATION AND FOR EXPLORATORY DRILLING}

At the beginning of this project, INL and other stakeholders held a workshop to identify the process that was to be used to conduct this study. INL recommended a multi-year, three-step process: Step 1 - compile and synthesize all relevant information; Step 2 - focused acquisition and collection of appropriate field data to narrow the area of interest; and Step 3 - test the best target(s) with drilling. During this first year of the assessment, Step 1 was completed and some of the required field data for Step 2 were collected. In the process, the area of focus for further exploration has been dramatically reduced. Initially, the entire UTTR was evaluated (about $1500 \mathrm{mi}^{2}$ ) and four focus areas were identified for further consideration. Focus Area 1 and its surrounding region (a total area of about $400 \mathrm{mi}^{2}$ ) were selected for further evaluation and for field investigations. The five field investigations completed in 2011 have further reduced the area of interest to the northwestern part of Focus Area 1 (about $60 \mathrm{mi}^{2}$ ). It is a triangular area extending from the Blue Lakes-Mosquito Willey's springs northward and northeastward to the northern boundary of Focus Area 1, as shown in Figure 6.0-1. Keeping in mind that a typical geothermal field in the Great Basin has a footprint in the range of 1-4 $\mathrm{mi}^{2}$ and a target depth of 1-3 km, the importance of further refining the area of interest before large sums of money are invested in the drilling of a deep exploration well or wells makes good logical sense (see Table 6.0-1).

Table 6.0-1. Additional geothermal exploration activities recommended for UTTR-S.

\begin{tabular}{|c|c|c|c|c|}
\hline Description & Purpose & Priority & Cost & Comments \\
\hline $\begin{array}{l}\text { In fill of gravity } \\
\text { coverage }\end{array}$ & $\begin{array}{l}\text { Greater resolution of } \\
\text { deep fault geometry }\end{array}$ & high & $\$ 75 \mathrm{~K}$ & 2011 basis \\
\hline $\begin{array}{l}\text { High-resolution } \\
\text { aeromagnetic } \\
\text { survey }\end{array}$ & $\begin{array}{l}\text { Greater resolution of } \\
\text { shallow fault geometry }\end{array}$ & high & $\$ 130 \mathrm{~K}$ & $\begin{array}{l}\text { Estimated from } \\
\text { UGS/USGS } 2011 \\
\text { prices }\end{array}$ \\
\hline $\begin{array}{l}2 \text { meter } \\
\text { temperature } \\
\text { survey }\end{array}$ & $\begin{array}{l}\text { Identify temperature } \\
\text { anomalies }\end{array}$ & $\begin{array}{l}\text { low to high, } \\
\text { depending on test } \\
\text { results }\end{array}$ & $\$ 10 \mathrm{~K}$ & ROM \\
\hline $\begin{array}{l}6 \text { geothermal } \\
\text { temperature } \\
\text { gradient wells }\end{array}$ & $\begin{array}{l}\text { Define temperature } \\
\text { distributions and } \\
\text { gradients, particularly } \\
\text { in relationship to } \\
\text { faults }\end{array}$ & high & $\$ 930 \mathrm{~K}$ total & $\begin{array}{l}\text { Cost estimate based on } \\
450 \text {-meter wells }\end{array}$ \\
\hline $\begin{array}{l}\text { Technical \& } \\
\text { project } \\
\text { management }\end{array}$ & $\begin{array}{l}\text { Technical oversight \& } \\
\text { project management of } \\
\text { drilling contracts \& } \\
\text { permits }\end{array}$ & high & $\$ 515 \mathrm{~K}$ & $\begin{array}{l}\text { ROM }(10 \% \text { of total } \\
\text { costs })\end{array}$ \\
\hline $\begin{array}{l}2 \text { geothermal } \\
\text { exploration deep } \\
\text { wells }\end{array}$ & $\begin{array}{l}\text { Encounter geothermal } \\
\text { fluids and quantify } \\
\text { temperature and flow }\end{array}$ & $\begin{array}{l}\text { High (completed as } \\
\text { part of last phase) }\end{array}$ & $\begin{array}{l}\$ 4,000 \mathrm{~K} \\
\text { Total }\end{array}$ & ROM for $2,000 \mathrm{M}$ well \\
\hline
\end{tabular}




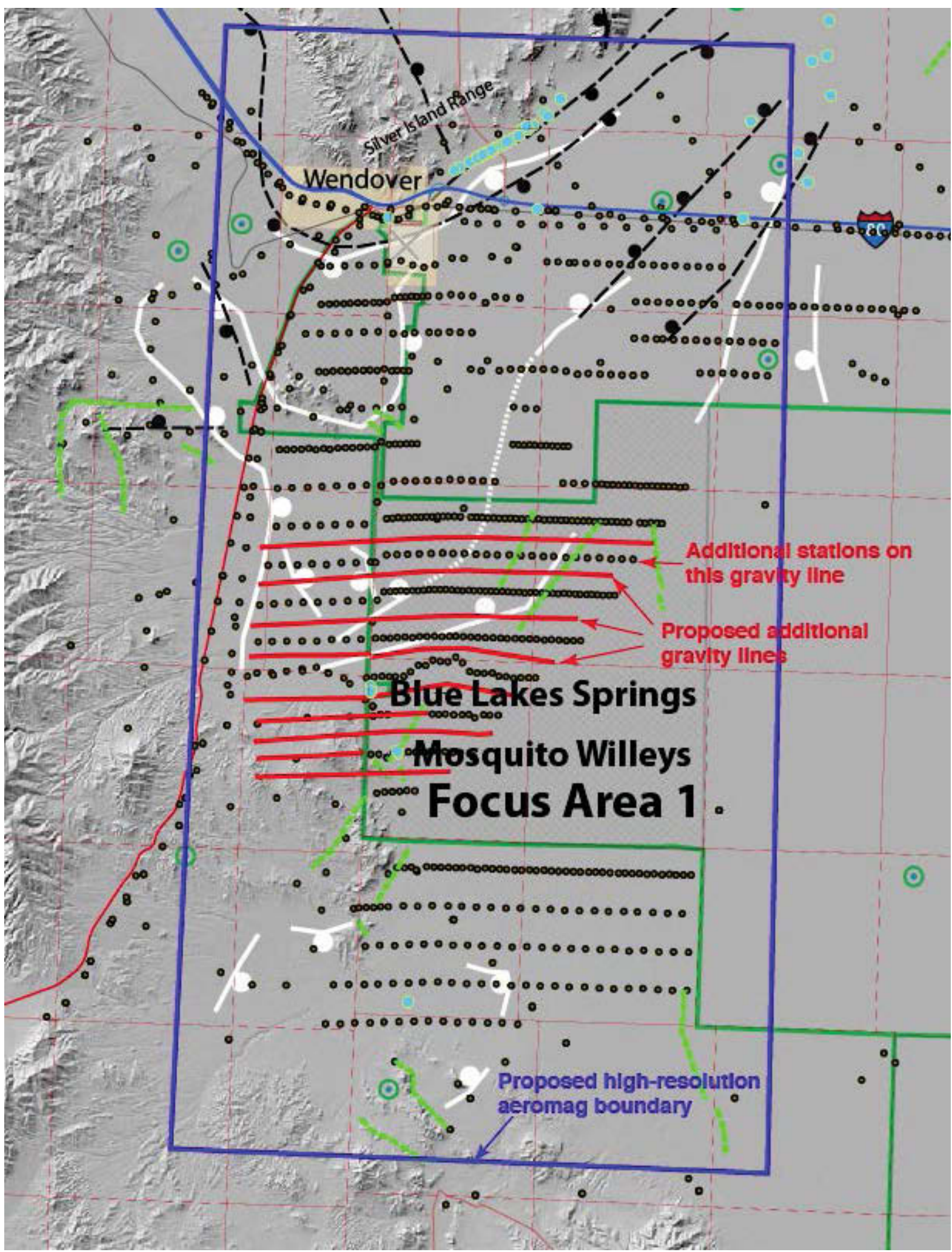

Figure 6.0-1. Proposed additional lines of gravity stations (red lines) and boundaries for a high-resolution aeromagnetic survey (blue polygon). Also, additional gravity stations are recommended for one of the lines acquired in 2011. Black dots with brown fill are gravity stations acquired in 2011. All other symbols are the same as those on previous figures. 
The field investigations of 2011 defined the basic geometry of the Wendover graben in and near Focus Area 1, produced additional subsurface temperature information, evaluated the chemistry of waters from thermal springs and wells in the area, and defined a smaller area worthy of further investigation. At this point, we recommend an approach that consists of very focused, aerially limited, and relatively inexpensive geophysical surveys and shallow drilling designed to identify a target or targets for deep exploratory drilling. The order of presentation in the following paragraphs is not intended to indicate priority or sequence. In Table 6.0-1 we have made some first assessment of priority, but that is subject to discussion among the stakeholders and levels of available funding.

Two geophysical surveys to further refine the geometry of faulting in the area are recommended. The first is to increase the level of gravity coverage in the area of interest. This would involve the addition of four additional lines of gravity stations between the lines acquired in 2011 and decreasing the station spacing on one of the 2011 gravity lines, as shown in Figure 6.0-1 and discussed in Table 6.0-1. This will provide greater resolution of the geometry of faulting at depth (i.e., at the depth at which low-density sediments within the buried graben are juxtaposed against high-density bedrock flanking the graben). The location and depth of the faults is required for deep exploratory drilling. The second recommended survey is a highresolution aeromagnetic survey to further define the geometry of faulting and to provide information about highly magnetic rocks (basalt, andesite, igneous intrusions) in the subsurface. Such surveys have been done in northwestern Utah and have proven extremely useful in defining both shallow and deep subsurface structure. This survey should extend southward from the southern boundary of the aeromagnetic survey performed by UGS and USGS in 2011 to well beyond the southern boundary of Focus Area 1 (Figure 6.0-1). It should match the specifications of the 2011 aeromagnetic survey and be coordinated with the USGS personnel who processed and interpreted the 2011 aeromagnetic data for best results. Information gained from both these surveys is important to resolve uncertainties in the plumbing systems of the thermal springs (i.e., Blue Lakes and Mosquito Willey's), to further define the geometry and age of graben-bounding faults, reveal the presence of strongly magnetic and dense volcanic rocks which could affect structural interpretations, and to place constraints on the locations and dips of faults.

Determination of the variability and distribution of thermal gradients in the exploration area is also important. There are two potential ways to get subsurface thermal gradient information. The first involves the use of 2-meter temperature probes (see Table 6.0-1) that are driven into the ground to determine thermal gradients just below the surface. In many instances, this method also provides thermal gradient information that can be reliably extrapolated to depth. However, in the UTTR area, presence of shallow, saline aquifers and the periodic inundation of some areas by overflow waters from the Great Salt Lake or other local flooding events will probably limit the usefulness of this method. It could be tested in the Blue Lakes and Mosquito Willey's springs areas to see if it is capable of determining gradient variations around the springs, but it is probably not capable of revealing anything about the deep temperature regime. Drilling of a pattern of thermal gradient wells will be required for learning about deep temperatures and gradient variations with depth.

Based on existing information, a pattern of four to six thermal gradient wells is recommended for the northwest corner of Focus Area 1. Using temperature data from the Intrepid deep brine wells (see Figures 5.1-1 and 5.2-3) as an analogy, six potential sites (\#'s 1-6) were chosen (and are indicated in Figure 6.0-2) to help answer several questions: (1) Do water 
temperatures and thermal gradients increase in the direction of the boundary faults north of Blue Lakes springs from the northwest corner of the focus area?; (2) Are maximum temperatures encountered comparable to those in DBW-3?; (3) Do thermal gradients and temperatures decrease southeast of the boundary fault system?; (4) Do thermal gradients vary along the trend of the boundary fault system?; (5) Is there a thermal gradient maximum near the surface projections of the boundary faults?; and (6) Is there a gradient reversal (i.e., decreasing temperatures with depth) in any of the wells? If so, a situation similar to that illustrated in Figure 6.0-3 (i.e., proposed well "A") may be indicated; and that information may help to adjust the locations of other gradient wells.

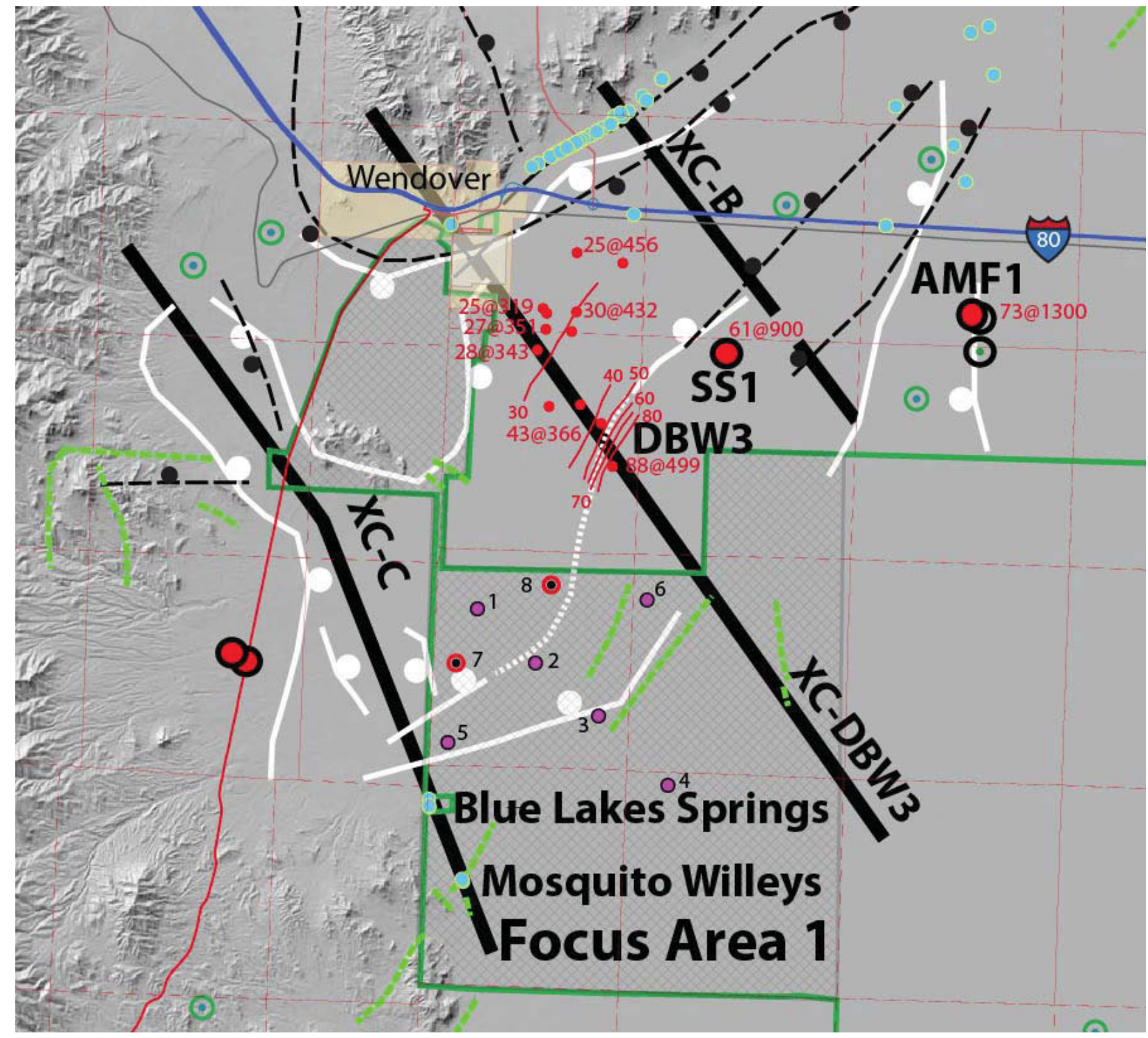

Figure 6.0-2. Map showing suggested locations of temperature gradient wells and deep exploration wells in Focus Area 1. See the figure caption for Figure 5.2-1 for symbols. Suggested locations of temperature gradient wells shown by black circles with pink fill and numbered 1 through 6 . Potential locations for deep exploration well(s) are shown by red circles with black dots and numbered 7 and 8 . 


\section{DBW3}

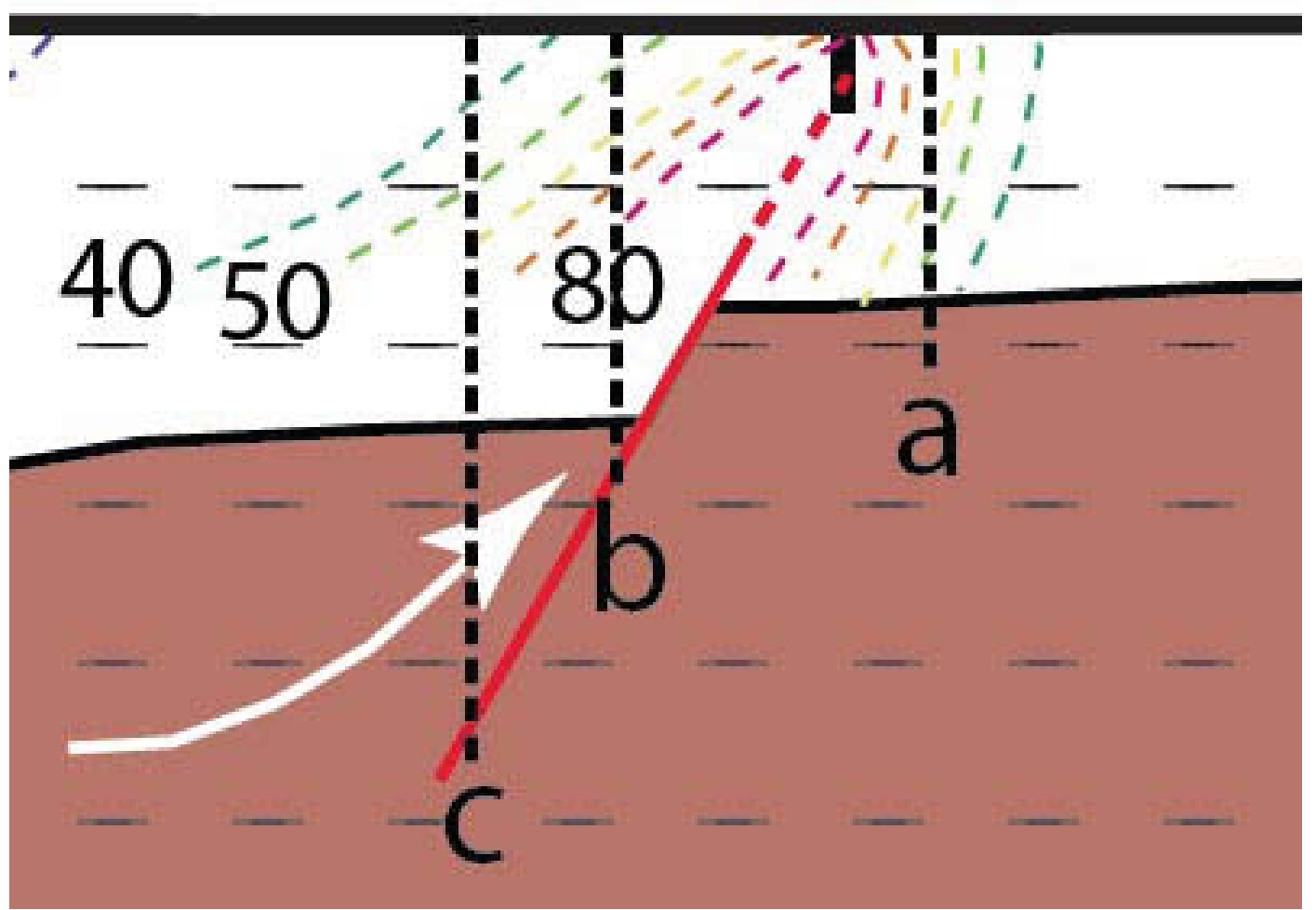

Figure 6.0-3. Enlargement of the area near DBW-3 in Cross-section DBW-3, with potential situations encountered by thermal gradient or deep exploration wells. In this enlargement, the colored lines represent an interpretation of temperature contours based on Turk's 1973 data; the vertical dashed black lines represent potential drill holes; and white arrow indicates potential upwelling of geothermal water; and the light horizontal dashed black lines indicate depths from $1-5 \mathrm{~km}$.

Using the deep brine wells on the Intrepid site for guidance, these wells may have to be $400-500 \mathrm{~m}$ deep to obtain meaningful results. Examination of Figure 4.2-2 shows that the temperature logs of the deep brine wells are very similar to depths of about $200 \mathrm{~m}$, perhaps controlled by a shallow aquifer system that masks deeper gradients. On Figure 4.2-2, it can be seen that only in depths below $200 \mathrm{~m}$ do the gradients for DBW's 8 and 17 diverge from the others and increase to a significant degree. Initial planning for the proposed thermal gradient wells in Focus Area 1 should include the possibility of drilling to $500 \mathrm{~m}$ depth. If temperature logs of the first proposed wells show distinguishable gradients at shallower depths, then the drilling depths may be decreased.

Other geophysical techniques that have been useful in geothermal exploration involve electrical surveys. These include standard resistivity surveys, electromagnetic surveys, magnetotelluric surveys, and self-potential (SP) surveys. These surveys give information about the locations, depths, dimensions, and movement of waters in aquifers and geothermal systems. Magnetotellurics has been used to reveal information about the deep plumbing of geothermal waters at the Dixie Valley geothermal field in Nevada and the Coso geothermal area in 
California (Wannamaker, 1999, 2003; Wannamaker et al., 2004, 2007). These techniques commonly depend on differences in electrical conductivity between geothermal waters and adjacent or overlying aquifers, and in most cases, the geothermal waters are more conductive because of higher dissolved ion concentration. However, in the area of Focus Area 1, water sampling has shown that the thermal spring waters at Blue Lakes is less saline than the shallow brine aquifers, and the reverse situation may be present here. Additionally, the shallow brine aquifers introduce complications that are not commonly encountered in electrical surveys.

Depending on results of geophysical surveys and thermal gradient drilling, a deep well would be located to intersect the boundary fault system at a depth sufficient to provide temperature and permeability suitable for electric power generation. Based on existing information, two potential deep exploration well sites (No.'s 7 and 8) are indicated in Figure 6.0-2. The high cost of these wells in relation to other surveys is indicated in Table 6.0-1 to emphasize the desirability of completing detailed geophysical investigations before embarking on a deep drilling program. Obviously, siting of these wells is likely to change as the detailed geophysics surveys are completed, but we anticipate that these wells would have to be drilled to a depth of at least 2000 meters. Potential deep well site \#7 may be the most promising location based on current information. This is because of the interpreted intersection of northwest-trending and northeasttrending faults in this area. In addition, it is near the deepest part of the graben system, providing opportunity for deeper circulation of groundwater, longer duration of fault activity, perhaps more intense deformation than elsewhere, and thicker cover of insulating Cenozoic sediments. Also, the Blue Lakes and Mosquito Willey's spring systems are nearby, and may be the upper part of a geothermal system originating in the deepest part of the graben (see Figure 5.2-2). 


\section{REFERENCES}

Blackett, R. E., and S. I. Wakefield, 2002, Geothermal Resources of Utah: A Digital Atlas of Utah's Geothermal Resources, Utah Geological Survey.

Blackett, R. E., Sowards, G. M., and Trimmer, E., 2004, Utah's High Temperature Geothermal Resource Potential - Analysis of Selected Sites, Utah Geological Survey.

Blackwell, D. D., 2007, "Summary of DOE Geoscience Studies of the Dixie Valley Geothermal System," Stanford University Geothermal Workshop, Stanford University, Stanford, California, January 30-February 1, 2007.

Coolbaugh, M., et al., 2005, Geothermal Potential Map of the Great Basin Region, Western United States, Nevada Bureau of Mines and Geology, Map 151 [Available at: http://www.nbmg.unr.edu/geothermal/published_maps.htm].

Cook, K. L., M. O. Halverson, J. C. Stepp, and J. W. Berg, Jr., 1964, "Regional Gravity Survey of the Northern Great Salt Lake Desert and Adjacent Areas in Utah, Nevada, and Idaho," Geol. Soc. Am. Bull., 75, 715-740.

Currey, D. R., 1980, “Coastal Geomorphology of Great Salt Lake and Vicinity,” in: Gwynn, J. W., ed., Great Salt Lake-A Scientific, Historical, and Economic Overview, Utah Geological and Mineral Survey Bulletin \#116, 69-82.

DiPippo, R. 2005. Geothermal Power Plants: Principles, Applications, and Case Studies, Elsevier Advanced Technology, Oxford, England.

Dinter, D. A., and J. C. Pechmann, 1999, "Multiple Holocene Earthquakes on the East Great Salt Lake Fault, Utah: Evidence from High-Resolution Seismic Reflection Data," Eos Trans. Am. Geophys. Union, 80(46), Supplement, F734.

Fitter, J. L., 1985, Seismic investigation near Silver Island in the Great Salt Lake Desert, Utah, M. S. Thesis, University of Oklahoma, Norman, OK, USA.

Fournier R. O., 1981, “Application of water geochemistry to geothermal exploration and reservoir engineering," in: Ryback and Muffler (eds.), Geothermal Systems: Principles and Case Histories, 109-143, John Wiley and Sons, New York, NY, USA.

Giggenbach, W. F., 1991, Chemical techniques in geothermal exploration," in: UNITAR/UNDP Guidebook: Application of Geochemistry in Resources Development, 119-144.

Hammond, W. C., and W. Thatcher, 2004, "Contemporary Tectonic Deformation of the Basin and Range Province, Western United States: 10 Years of Observation with the Global Positioning System," J. Geophys. Res., 109, B08403-B08423.

Hecker, S., 1993, Quaternary Tectonics of Utah with Emphasis on Earthquake-hazard Characterization, Utah Geological Survey Bulletin \#127, scale 1:500,000.

Heilweil, V. M., and L. E. Brooks, eds., 2011, Conceptual model of the Great Basin carbonate and alluvial aquifer system: U.S. Geological Survey Scientific Investigations Report 20105193, 191 p. [Available at: http://pubs.usgs.gov/sir/2010/5193/].

Henrikson, A., and D. S. Chapman, 2002, Terrestrial Heat Flow in Utah, University of Utah Department of Geology and Geophysics, Salt Lake City, UT, USA. 
Hintze, L. F., G. C. Willis, D. Y. M. Laes, D. A. Sprinkel, and K. D. Brown, 2000, Digital geologic map of Utah, Utah Geological Survey, [Available at: http://geology.utah.gov/maps/geomap/UTDigitalGeoMap/geomap/index.html].

Jones, B. F., W. W. White, III, K. M. Conko, D. M. Webster, and J. F. Kohler, 2009, Mineralogy and fluid chemistry of surficial sediments in the Newfoundland Basin, Tooele and Box Elder Counties, Utah, Utah Geological Survey Open File Report \#539.

Kim, K. Y., 1985, Seismic studies near Crater Island in the Great Salt Lake Desert, Utah, M. S. Thesis, University of Oklahoma, Norman, OK, USA.

Langmuir, D., 1971, The geochemistry of some carbonate groundwaters in central Pennsylvania. Geochim. Cosmochim. Acta, 35, 1023-1045.

McCalpin, J., 1985, Quaternary Fault History and Earthquake Potential of the Hansel Valley Area, North-Central Utah, USGS Final Technical Report.

Moore, J., and R. Allis, 2011, "Novel Geothermal Development of Deep Sedimentary Systems in the United States," Proposal submitted to U.S. Department of Energy.

Morrison, R. B., 1991, “Quaternary Stratigraphic, Hydrologic, and Climatic History of the Great Basin, with Emphasis on Lake Lahontan, Bonneville, and Tecopa," in: Morrison, R. B. (ed.), Quaternary Nonglacial Geology: Conterminous United States, K2, 283-320, Geological Society of America, Boulder, CO, USA [Available at: http://esp.cr.usgs.gov/info/mojave/paleoenviron.html].

Mikulich, M. J., and R. B. Smith, 1974, Seismic-reflection and aeromagnetic surveys of the Great Salt Lake, Utah, Geological Society of America Bulletin, 991-1002.

Rene, R. M., J. L. Fitter, D. J. Murray, and J. K. Walters, 1988, "Reflection and Refraction Seismic Studies in the Great Salt Lake Desert, Utah,” J. Geophys., 53(4), 431-443.

Robison, R. M., 1986, The Surficial Geology and Neotectonics of Hansel Valley, Box Elder County, Utah, unpublished M. S. Thesis, Utah State University, Logan, Utah, USA, scale $1: 24,000$.

Sass, J. H., A. H. Lachenbruch, R. J. Munroe, G. W. Greene, and T. H. Moses, Jr., 1971, "Heat flow in the Western United States," J. Geophys. Res., 76, 6376-6413.

Sass, J. H., S. S. Priest, A. J. Blanton, P. C. Sackett, S. L. Welch, and M. A. Walters, 1999, Geothermal Industry Temperature Profiles from the Great Basin, USGS Open File Report \#99-425 [Available at: http://pubs.usgs.gov/of/1999/of99-425/].

Schalla, R.A and E. H. Johnson (eds.), 1994, Oil Fields of the Great Basin: Nevada Petroleum Society Special Publication, Nevada Petroleum Society, Reno, NV, USA.

Schneyer, J. D., 1990, Geologic Map of the Leppy Peak Quadrangle, Nevada and Utah, USGS Misc Inv Series Map I-1938, scale 1:24,000.

Smith, R. P., Breckenridge, R. P., and Wood, T. R., 2011, "Preliminary Assessment of Geothermal Potential at the UTTR," INL/EXT-11-22215, Rev. 0, Idaho National Laboratory external report, Idaho Falls, ID, USA.

Stewart, J. H., and J. E. Carlson, 1978, Geologic map of Nevada, U.S. Geological Survey and Nevada Bureau of Mines and Geology, scale 1:500,000. 
Turk, L. J., 1973, Hydrogeology of the Bonneville Salt Flats, Utah Geological and Mineral Survey Water Resources Bulletin \#19.

Utah Geothermal Working Group, 2005, Geothermal Energy Development in Utah, Position paper.

Viveiros, J. J., 1986, Cenozoic tectonics of Great Salt Lake from seismic-reflection data, unpublished M. S. Thesis, University of Utah, Salt Lake City, Utah, USA.

Wannamaker, P. E., 1999, "Affordable magnetotellurics: interpretation in natural environments," in: M. Oristaglio and B. Spies (eds.), Three-dimensional Electromagnetics, Geophysical Development Series 7, 349-374, Society of Exploration Geophysicists, Tulsa, OK, USA.

Wannamaker, P.E., 2003, "Initial results of magnetotelluric array surveying at the Dixie Valley geothermal area, with implications for structural controls and hydrothermal alteration; Geothermal Resources Council Transactions, 27, 37-42.

Wannamaker, P. E., P. E. Rose, W. M. Doerner, B. C. Berard, J. McCulloch, and K. Nurse, 2004, "Magnetotelluric Surveying and Monitoring at the Coso Geothermal Area, California, in Support of the Enhanced Geothermal Systems Concept: Survey Parameters and Initial Results," Proceedings of the Workshop on Geothermal Reservoir Engineering, Stanford University, Stanford, CA, USA, January 22-24, SGP-TR-175.

Wannamaker, P. E., W.M. Doerner, and D. P. Hasterok, 2007, "Integrated Dense Array and Tansect MT Surveying at Dixie Valley Geothermal Area, Nevada: Structural Controls, Hydrothermal Alteration and Deep Fluid Sources," Proceedings of $32^{\text {nd }}$ Workshop on Geothermal Reservoir Engineering, Stanford University, Stanford, CA, USA, January 22-24, SGP-TR-183, 402-407.

Whelan, J. A., and C. A. Petersen, 1974, "Bonneville Salt Flats-A Possible Geothermal Area?," Utah Geology, 1(1), 71-82.

Wold, S. R., and K. M. Waddell, 1993, Salt Budget for West Pond, Utah, April 1987 to June 1989, USGS Water Resources Investigations Report \#93-4028. 


\title{
Appendix A
}

\section{Western UTTR Gravity Surveys \& Processing}

\author{
Paul Gettings \\ Dept. of Geology and Geophysics, University of Utah
}

\section{Introduction}

To help determine the subsurface structure, and hence favorable exploration targets, the Utah Geological Survey (UGS) acquired new gravity data in Priority Areas 1, 2, and the southern part of Priority Area 3; the northern part of Priority Area 3 was closed due to security concerns. Some gravity measurements and gravity modeling, primarily by Cook et al. (1964), have been performed in this area but generally, the gravity coverage is sparse (see Figure 4.1-1). Existing gravity stations were extracted from the PACES database maintained by the University of Texas at El Paso, which holds collected station information for the continental U.S. New gravity stations for this investigation are located in areas of historically poor coverage, and were selected to leverage the existing coverage to maximize the extent of the gravity mapping. Figure A-1 shows the study area with existing and new gravity stations; note that seven existing stations (collected during previous investigations) were reoccupied during this survey to determine offsets between the 1970s-era data and the new gravity stations.

A total of 686 new stations provided coverage at 800 and $400 \mathrm{~m}$ in-line spacing (E-W), and $\sim 2 \mathrm{~km}$ cross-line spacing (N-S). Most stations were accessed using All Terrain Vehicles (ATVs); however, some areas were inaccessible due to ground conditions, such as active evaporation ponds or deep mud. Trimble survey-grade dual-frequency receivers were used for positioning each station during the gravity readings.

Exploration gravity data, such as acquired in this survey, reflect the density and depth of the subsurface materials between land surface and the center of the Earth. However, because deep structure has small amplitude and large wavelengths, it is possible to focus the interpreted gravity signal on the near-surface structure by removing a large-scale anomaly signal. Note that the gravity data presented here are quoted in $\mathrm{mGal}$, which are equivalent to $10^{-5} \mathrm{~m} / \mathrm{s}^{2}$; the average Earth gravity field is $980,000 \mathrm{mGal}$.

Based on assembled portions of geologic maps of the region around the study area, the basement is interpreted to be a mix of Paleozoic sedimentary rocks, mostly quartzite and limestone. There are few exposures of bedrock in the study area, and only at the extreme edges, so actual basement lithology can only be inferred. The sedimentary cover is lacustrine, but maps show only undifferentiated alluvium. Cross sections were assembled from a number of neighboring maps, due to the lack of exposures in the study area and the large scale of maps covering the site. A detailed geologic map of the area immediately west of the study area (Leppy Peak Quadrangle) was particularly useful. Cross sections were also assembled from the Gold Hill and Pilot Peak quadrangles for comparison. Due to the lack of basement exposures in the study area, rock densities have therefore been assumed based on averages for the various rock types. 


\section{Data Acquisition \& Processing}

Gravity data were acquired using two Scintrex CG-5 gravimeters. Station occupations consisted of six-minute time series of 30-second averages. Time series were corrected for Earth tides using the harmonic formulation from Tamura (1987). Time series are converted to a single gravity reading using a weighted average, after dropping the first three minutes to remove transport effects. Instrument drift is removed using linear interpolation between repeated occupations of local and remote base stations. The drift function, acquisition, and processing techniques are described in detail in Gettings et al (2008).

Position data were acquired using Trimble dual-frequency survey-grade receivers. Some positions were suitable for post-processing, but errors within the Trimble device software prevent post-processing of all locations. Stations without post-processed positions used the six-minute averages in the field. Post-processed positions are accurate to $0.1 \mathrm{~m}$ or better in horizontal location and elevation; the six-minute averages are accurate to $1 \mathrm{~m}$ or better in horizontal location, and $2 \mathrm{~m}$ or better in elevation. Error bounds have been assumed using a constant position error of $1 \mathrm{~m}$ for all stations; $1 \mathrm{~m}$ elevation error translates to $0.309 \mathrm{mGal}$. It should be noted that existing gravity stations have position and elevation accuracy of at best $1 \mathrm{~m}$, so the new stations compare favorably with the old.

Gravity readings at field stations were compared to the absolute gravity value at the University of Utah base station at the President's Circle benchmark. Absolute gravity at the benchmark was last measured in 1996, but drift in the gravity value at the benchmark due to hydrologic and position changes will be on the order of $0.1 \mathrm{mGal}$ or less, and is ignored.

Observed gravity values at the new stations were compared with existing data at the seven existing stations (new stations within $10 \mathrm{~m}$ of old stations). The average offset of $1.975 \mathrm{mGal}$ between the old gravity stations and the new gravity stations has been subtracted from the new stations, so all stations can be used in a single, consistent map.

For interpretation, the observed gravity values are converted to a CBGA. Theoretical gravity due to the rotating ellipsoid (latitudinal and shape-of-the-Earth effects), elevation effects (free-air correction), and terrain effects have been removed. See Hinze (2005) for a discussion of the modern reference equations for theoretical gravity and the various corrections. The free-air correction assumed a typical gradient of $-0.3086 \mathrm{mGal} / \mathrm{m}$. Bouguer slab, curvature, and terrain corrections have been computed using an assumed density of $2400 \mathrm{~kg} / \mathrm{m}^{3}$. Terrain corrections for near-station topography computed using half cones and half slopes, based on sketches of nearstation topography drawn during acquisition. Most stations did not need any near-zone corrections. Terrain corrections were computed to a radius of $166.7 \mathrm{~km}$ using a global code based on $468 \mathrm{~m}$ spherical diamonds and SRTM digital elevations (Gettings, 2012). Testing with various Bouguer reduction densities between 2200 and $2800 \mathrm{~kg} / \mathrm{m}^{3}$ showed a minimum correlation of CBGA with elevation at $2400 \mathrm{~kg} / \mathrm{m}^{3}$.

All stations are used in an equivalent-source method to create a regular N-S/E-W grid (Cordell, 1992). Grid interval is set to $1 \mathrm{~km}$, for the range $225-270 \mathrm{~km}$ easting, 4460-4520 km northing. Figure A-2 shows the gridded observed anomaly map (upper left panel) and its horizontal gradients (remaining three panels). This upper left panel, showing the observed anomaly, has the average anomaly $(-142.68 \mathrm{mGal})$ subtracted to allow interpretation to focus on the shallow structure. The average anomaly reflects the broad, deep structure of the crust in Utah 
and Nevada, which is not of interest in this project. The upper right panel shows the magnitude of the horizontal gradient. High gradient values indicate areas of rapid change, which are associated with faults and other sharp structural boundaries. The individual easting $\left(g \_x\right)$ and northing (g_y) gradient maps highlight changes in the E-W and N-S directions.

\section{Discussion \& Modeling of Basin Structure}

Due to station coverage lacking in the northern part of Priority Area 3, the central and southern eastern portion of the anomaly map (Figure A-1, areas without blue triangles) is not to be trusted. The deep gravity low in the central western portion of the anomaly map (Figure A-1, 230-245 km easting, 4585 to $4510 \mathrm{~km}$ northing) indicate a deep buried basin; the high anomaly values immediately east indicate shallow buried basement adjacent to the basin. Station coverage clearly shows that there is a bedrock high bordering the east edge of the buried basin, but the high could be a ridge and not a plateau as suggested by the interpolation of data in an area with poor coverage. Due to security limitations, stations were not allowed in the northern part of Priority Area 3, and thus it is not possible to determine the structure in that area.

As a first pass of modeling the buried structure, the observed gravity anomalies at stations are gridded at a $1500 \mathrm{~m}$ interval (using the same technique as for Figure A-2), and a Newton's Method inversion for a two-layer system is performed. An initial model of $1000 \mathrm{~m}$ depth-tobasement and $3000 \mathrm{~m}$ total depth across the whole space is used. Iterations update individual columns with a new depth-to-basement, constrained to a minimum of zero. Sediments are assumed to have a constant density of $2000 \mathrm{~kg} / \mathrm{m}^{3}$, while the basement is assigned a density of $2800 \mathrm{~kg} / \mathrm{m}^{3}$ (suitable for a mixture of limestone, quartzite, dolomite, etc.). Iterations are continued until the RMS difference (model-observed) increases, the difference change drops below $10^{-4} \mathrm{mGal}$, or 100 iterations is reached. For the $1500 \mathrm{~m}$ grid, eight iterations achieve an RMS difference of $0.473 \mathrm{mGal}$ with differences between observed and modeled anomaly bounded between -2 to $+5 \mathrm{mGal}$.

Figure A-3 shows the observed gridded data (with stations), the modeled gravity effect, the difference between what was modeled and what was observed, and the best-fit depth model. Note that the depth is computed relative to the elevation of each grid cell.

Depths range from 1001-2150 $\mathrm{m}$ in the deep basin. The depth range depends on the assumed density contrasts - for example, using a basement density of $2700 \mathrm{~kg} / \mathrm{m}^{3}$ and a sediment density of $2000 \mathrm{~kg} / \mathrm{m}^{3}$ results in a depth range of 973-1866 m and final RMS difference of $0.303 \mathrm{mGal}$; likewise, using a basement density of $2800 \mathrm{~kg} / \mathrm{m}^{3}$ and a sediment density of $2100 \mathrm{~kg} / \mathrm{m}^{3}$ results in a depth range of 995-2850 $\mathrm{m}$ and a final RMS difference of $0.994 \mathrm{mGal}$. A sediment density of $2300 \mathrm{~kg} / \mathrm{m}^{3}$ with basement density of $2800 \mathrm{~kg} / \mathrm{m} 3$ yields a maximum basement depth of 3730 $\mathrm{m}$. As expected, the shape of the depth model does not depend on the chosen densities, but the maximum depth of the basin does. Maximizing the density difference between basement and basin fill minimizes the depth of the basin; decreasing the density contrast deepens the basin. The positive 5-10 mGal residuals (depending on chosen density contrasts) at the deepest basin block indicates that the modeled depth is a minimum in all cases.

The spatial pattern of the depth model is consistent with a deep basin system bounded by NE-SW trending faults; the largest and deepest basin is between 4490 and $4495 \mathrm{~km}$ northing, and is $\sim 5 \times 7 \mathrm{~km}$ in the north and east extent. Additional shallower basin-like geometries exist to the 
NE and NW of the deepest basin. The basement highs to the north and SE of the deep basin are sufficiently sharp to likely be caused by large offsets of fault(s).

Two-dimensional gravity models were built from the $1 \mathrm{~km}$ gridded data, as shown in Figure A-2. Figure A-4 provides the modeled lines overlain on the gridded CBGA values and on the gridded elevations. Note that the lines show significant gravity variations, but little elevation change. Figures A-5 and A-6 show the 2-D models. Note that the models assume constant densities of 2000 and $2800 \mathrm{~kg} / \mathrm{m}^{3}(-0.4 \mathrm{~g} / \mathrm{cc},+0.4 \mathrm{~g} / \mathrm{cc})$ as with the initial 3-D modeling. Lines across the gravity lows can be modeled as $2-3 \mathrm{~km}$ deep basins shallowing to $1 \mathrm{~km}$ on the west and east sides. As with most models, small changes in geometry can be made while maintaining the goodness of fit between the calculated and observed data. In particular, note that the sharp points of the models can be replaced with a broader, shallower boundary at the cost of increased geometric complexity. In Profile E, the sharp changes between 7 and $13 \mathrm{~km}$ must be related to near-surface geology; such rapid changes cannot be caused by interfaces at depths of $2+\mathrm{km}$ due to the diffusive nature of gravity. Recall that the profile data shown in Figure A-5 is taken from the gridded data set, and thus the sharp drops in gravity at 7 and $13 \mathrm{~km}$ along Profile E, and the sharp rebounds between 8 and $12 \mathrm{~km}$ are not just bad station occupations. Without better geologic maps, magnetic data, tighter gravity coverage, or other additional geophysics, it is not possible to identify what is causing the anomalously low (or high) gravity values between 7 and $13 \mathrm{~km}$ along profile E.

The long NW-SE profile, as shown in Figure A-6, warrants additional discussion. Note that the stepped, tilted model interfaces between 10 and $25 \mathrm{~km}$. The geometry of the profile model is consistent with either tilted graben blocks or small horst blocks at the bottom of the basin. Maximum sediment depths are up to $4.5 \mathrm{~km}$ below the surface. This is consistent with the 3-D modeling results - the 3-D model has a depth of 2.2 to $3 \mathrm{~km}$ at the same location, but the model is at least $5 \mathrm{mGal}$ too positive at the same point, indicating that the $3-\mathrm{D}$ model is not sufficiently deep in the best-fit model, but continued iterations of the 3-D inversion became unstable.

All models are consistent with a typical sediment thickness of about $1 \mathrm{~km}$ in the gravity highs, increasing to $2-4.5 \mathrm{~km}$ thick in the gravity lows.

Using the smaller $1500 \mathrm{~m}$ grid model and the 2-D lines as a basis, a qualitative interpretation of the larger, finer gravity grid of Figure 2 is straight-forward. The deep gravity low in the center (237 km easting, $4492 \mathrm{~km}$ northing) is the deep basin, bounded by faults running NE-SW along the high-gradient boundary between the deep low and adjacent gravity high. An additional basin is due south of the deep basin (235-245 km easting, $4470 \mathrm{~km}$ northing), but that basin appears to be bounded by nearly E-W faults to the north and south. Unfortunately, without additional station coverage in Priority Area 3, it is difficult to interpret what the basement high at the edge of the two basin systems looks like, and thus how to interpret the geologic structure between them.

\section{Acknowledgements}

Hobie Willis and Adam Hiscock of the Utah Geological Survey conducted most of the field work. Marie Green at the University of Utah built the 2-D models. 


\section{References}

Cordell, L., 1992, "A scattered equivalent-source method for interpolation and gridding of potential-field data in three dimensions," Geophysics, 57, 629-636.

Tamura, Y., 1987, “A harmonic development of the tide-generating potential," Bulletins d'Informations Marees Terrestres, 99, 6813-6855.

Gettings, P., D. S. Chapman, and R. G. Allis, 2008, "Techniques, analysis, and noise in a Salt Lake Valley 4D gravity experiment," Geophysics, 73, WA71-WA82.

Gettings, P., 2012, Techniques and Applications of Precision Gravity, Ph.D. dissertation, University of Utah, Salt Lake City, Utah, USA.

Hinze, W. J., C. Aiken, J. Brozena, B. Coakley, D. Dater, G. Flanagan, R. Forsberg, T. Hildenbrand, G. R. Keller, J. Kellogg, R. Kucks, X. Li, A. Mainville, R. Morin, M. Pilkington, D. Plouff, D. Ravat, D. Roman, J. Urrutia-Fucugauchi, M. Véronneau, M. Webring, and D. Winester, 2005, "New standards for reducing gravity data: The North American gravity database," Geophysics, 70, J25-J32. 


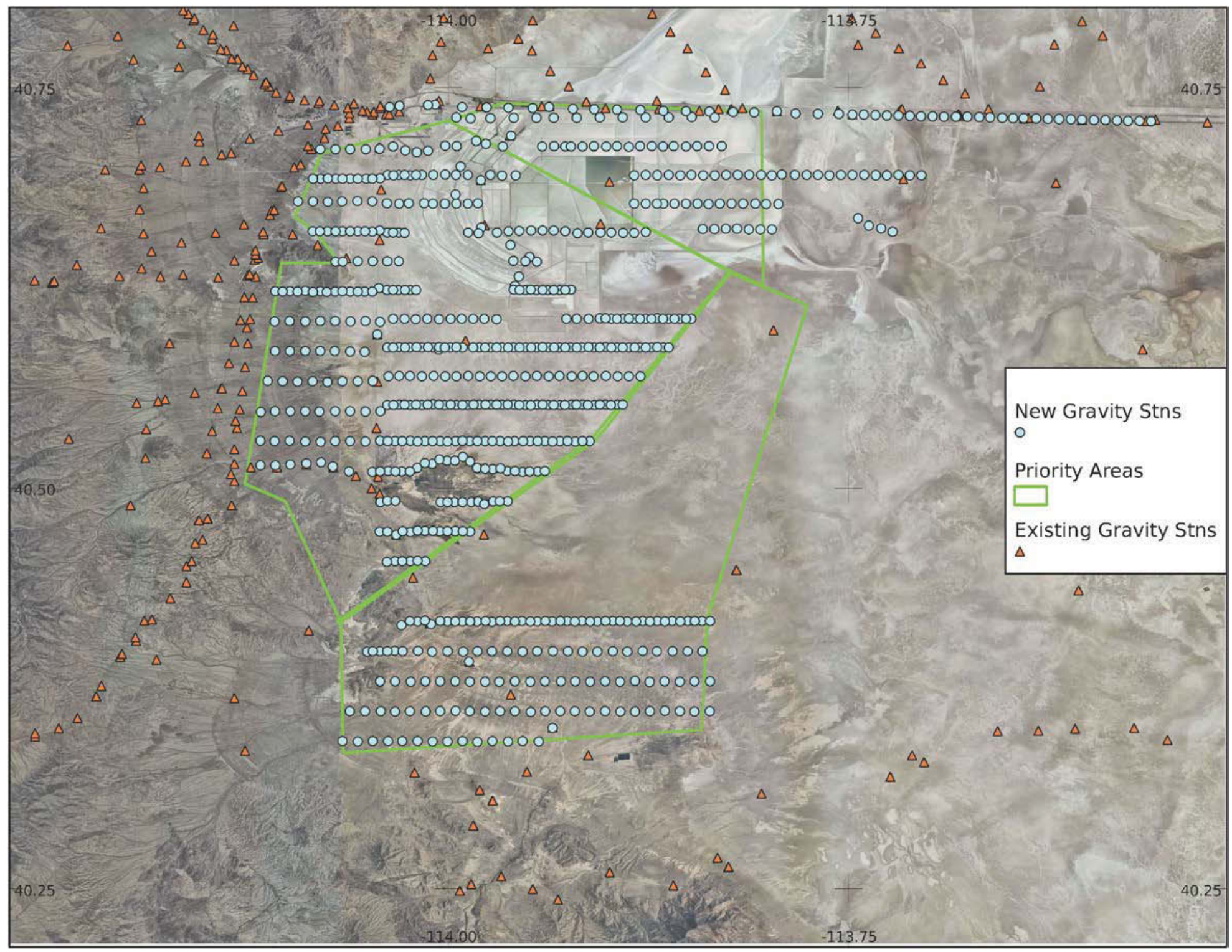

Figure A-1. Study area with existing and new gravity stations. Basemap is aerial photography of the Intrepid and UTTR areas. Priority areas are outlined in green. Coordinate crosses are 0.25 degrees apart. A total of 686 new stations were added in Priority Areas 1 through 3. 

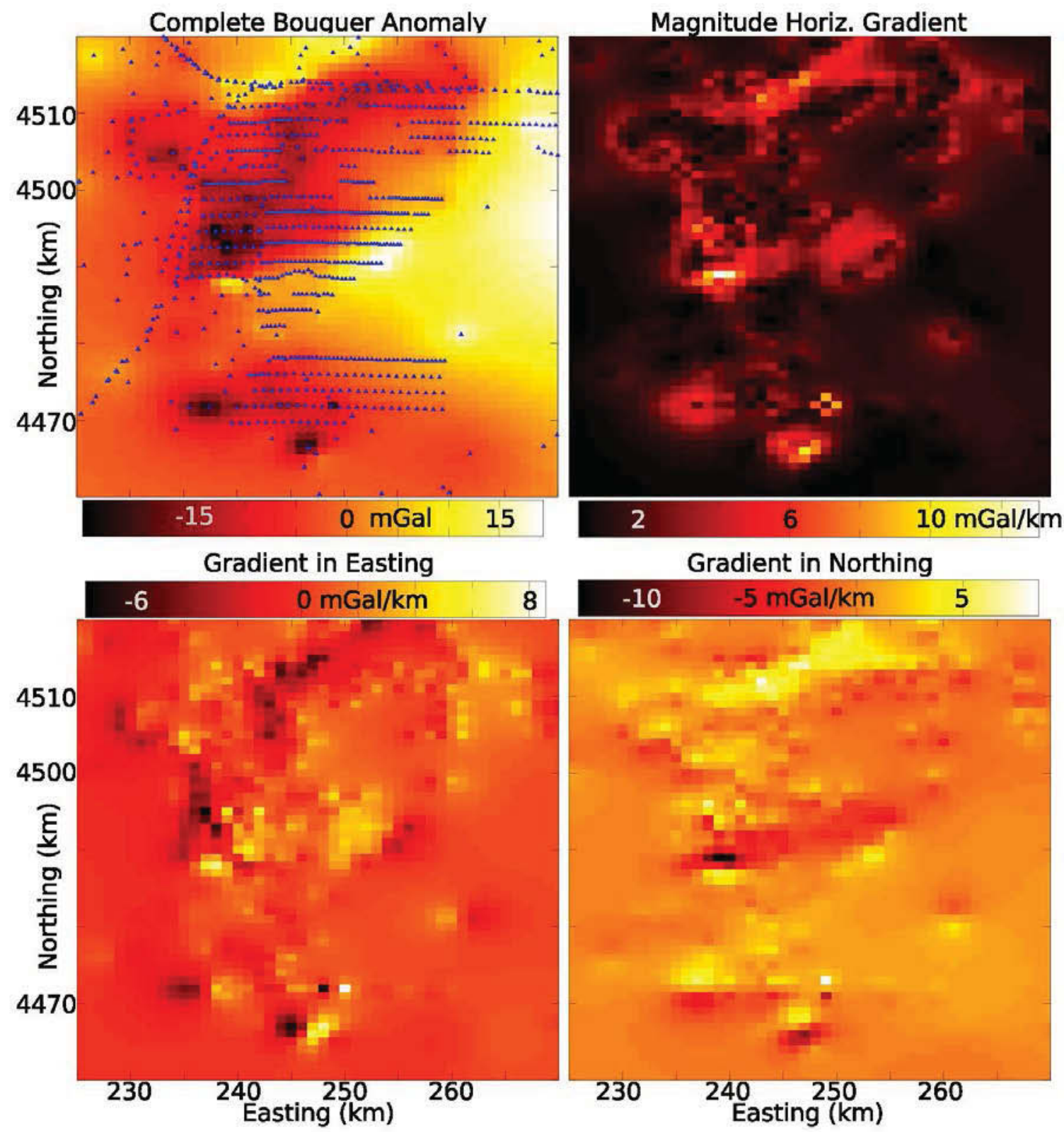

Figure A-2. Gridded complete Bouguer anomaly values, with horizontal gradients. Bouguer anomaly computed assuming $2400 \mathrm{~kg} / \mathrm{m}^{3}$ density. Grid computed at $1 \mathrm{~km}$ interval from all stations (shown as blue triangles), using an equivalent source technique (Cordell, 1992). Upper right panel shows the magnitude of the gradient; the bottom two panels are gradients in east and north directions. 


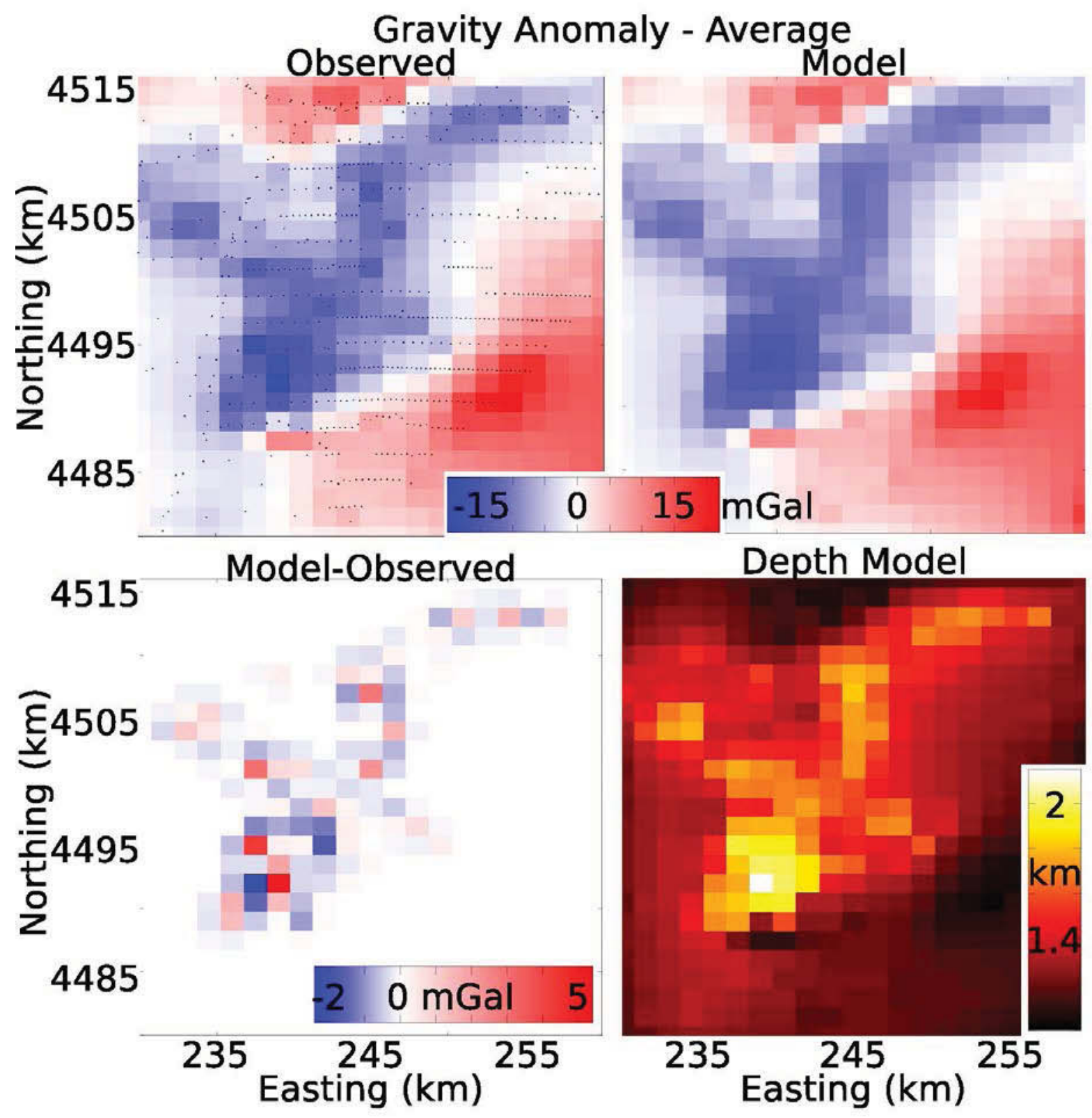

Figure A-3. 3-D depth-to-basement modeling. Upper left panel is observed with CBGA and gridded at $1.5 \mathrm{~km}$ spacing from all stations. Upper right panel is the calculated gravity anomaly from the 3-D model. Lower left panel is misfit (residual) between calculated and observed grids, in mGal. Lower right panel is the depth model in meters below surface. 


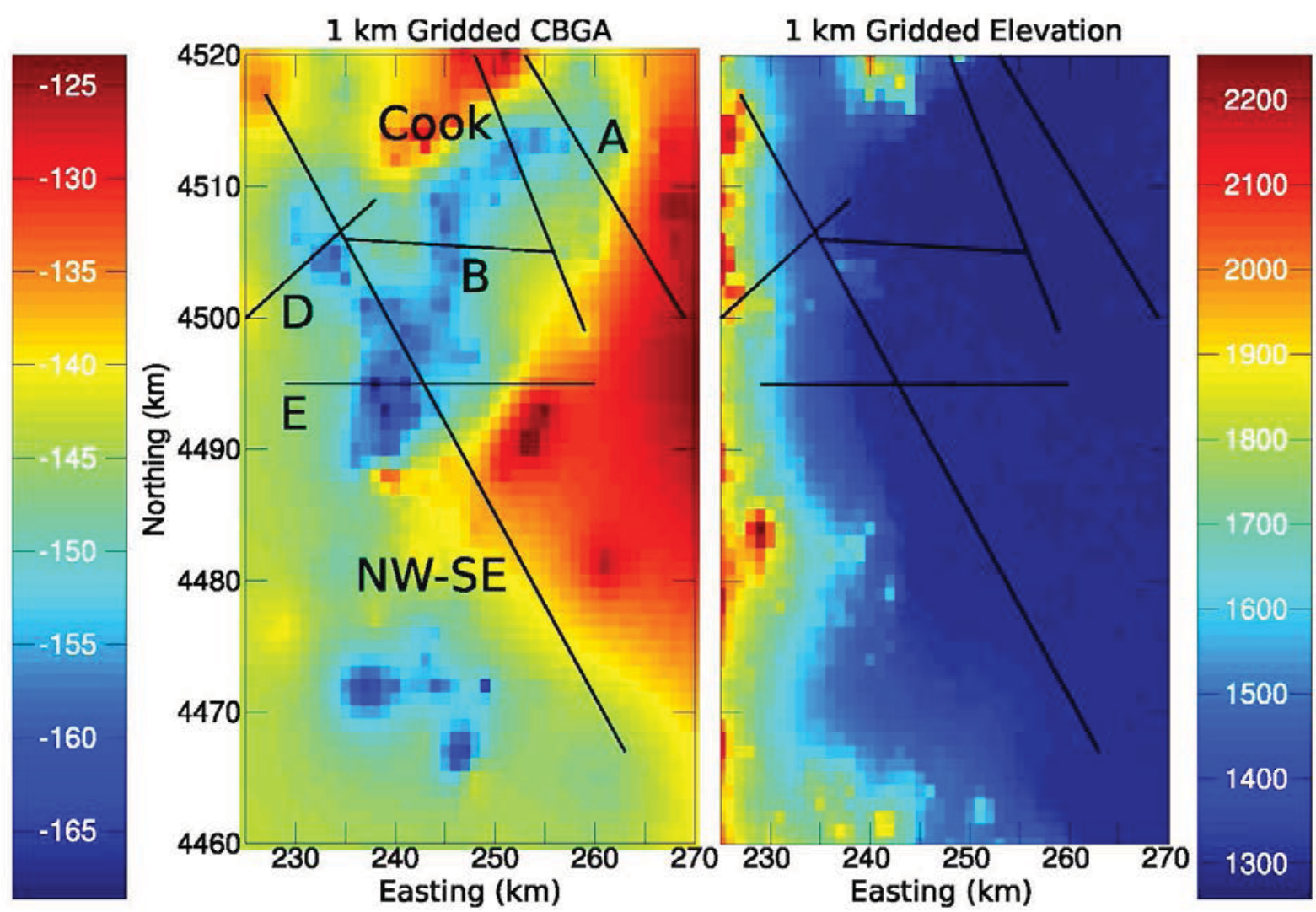

Figure A-4. Profile locations on gridded gravity anomaly and elevations. Left side shows profile locations on CBGA, in mGal. Right panel shows profiles on gridded elevations, in $\mathrm{m}$. 

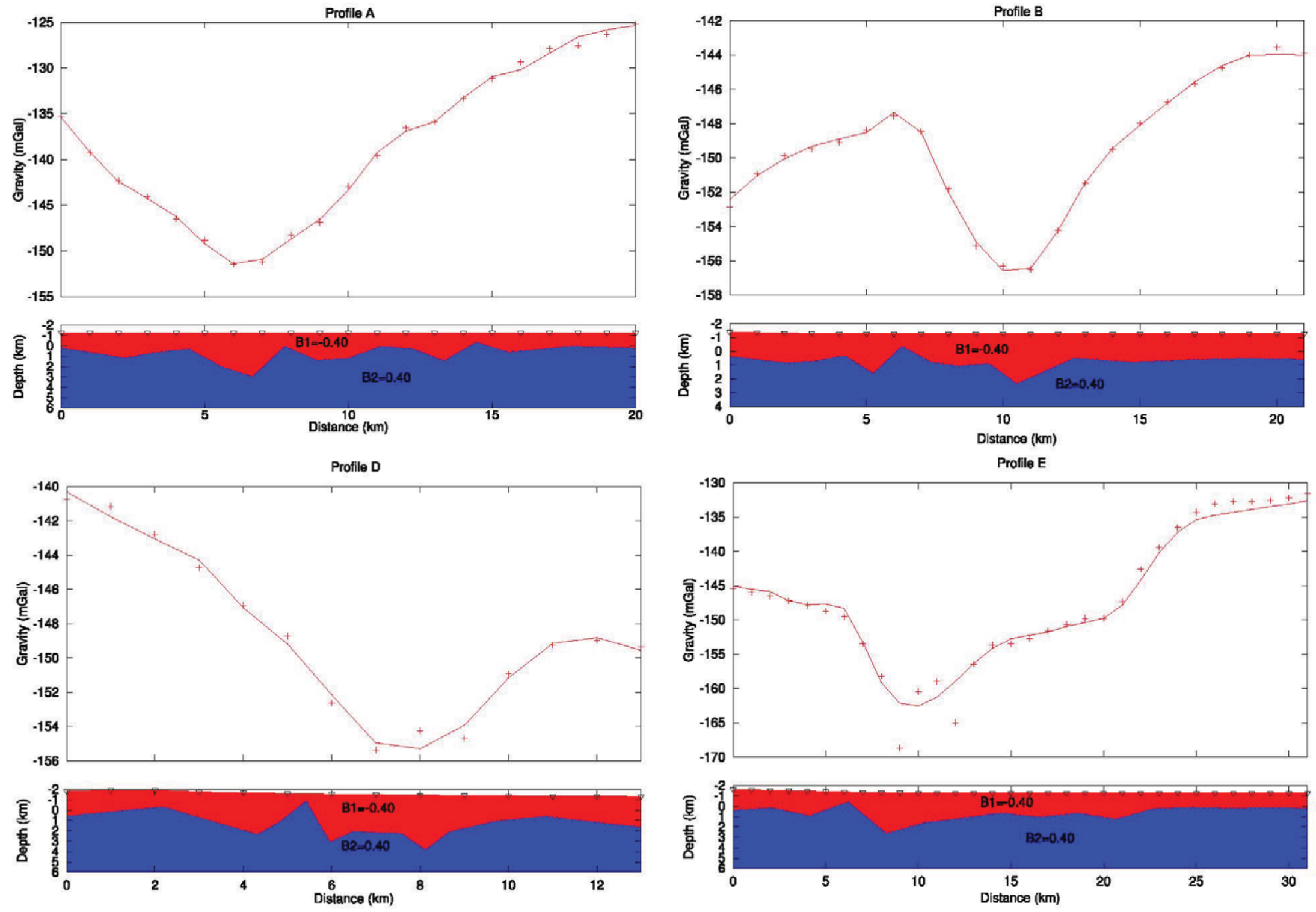

Figure A-5. Gravity models for profiles A, B, D, and E. Models computed assuming a -0.4 and $0.4 \mathrm{~g} / \mathrm{cc}$ density contrasts for sediment and basement $\left(2000\right.$ and $\left.2800 \mathrm{~kg} / \mathrm{m}^{3}\right)$. See text for discussion of model features. 

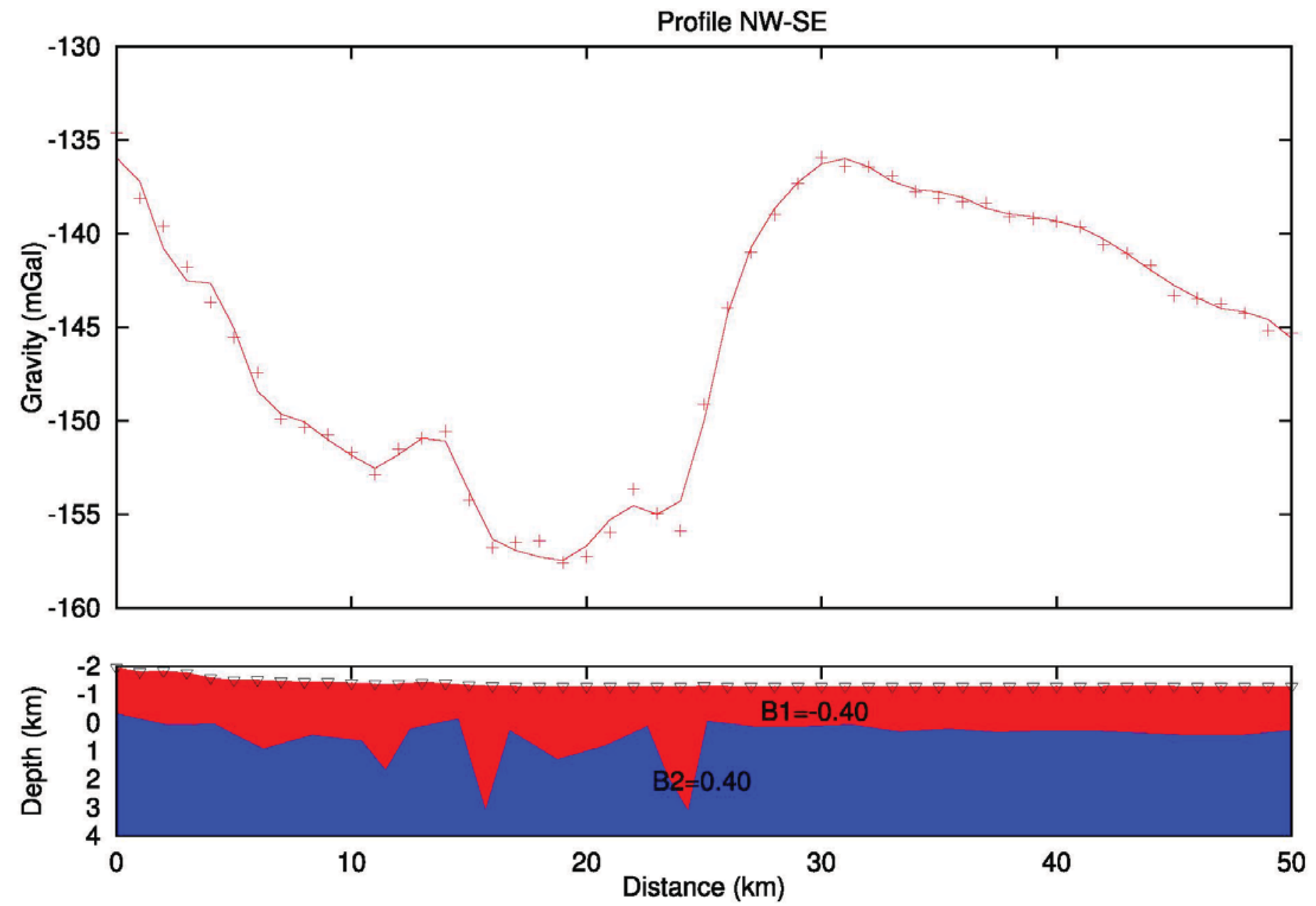

Figure A-6. Gravity model for long NW-SE profile. Bodies assumed to have $2000-2800 \mathrm{~kg} / \mathrm{m}^{3}$ constant densities. 
This page intentionally left blank. 


\title{
Appendix B
}

\section{Borehole Temperature Logging}

\author{
Robert Blackett, Mark Gwynn, and Andrew Rupke \\ Utah Geological Survey
}

\begin{abstract}
Based on data gathered from six deep brine wells within a study area located southeast of Wendover, Utah and adjacent west of the southern tract of the Utah Test and Training Range (UTTR), subsurface temperatures are elevated and suggest that hydrothermal fluids circulate to relatively shallow depths, possibly along faults marginal to the Wendover graben. Based upon an $88^{\circ} \mathrm{C}\left(190^{\circ} \mathrm{F}\right)$ temperature at $499 \mathrm{~m}(1637 \mathrm{ft})$ depth reported by Turk (1973) in well DBW-3, and down-hole temperature data from other deep brine wells owned by Intrepid Potash, subsurface temperatures appear to increase southeastward toward the west side of the southern tract of the UTTR. The highest temperature recorded in wells measured as part of this study was a bottom-hole temperature of $43.9^{\circ} \mathrm{C}\left(111^{\circ} \mathrm{F}\right)$ measured at $410 \mathrm{~m}(1345 \mathrm{ft})$ depth in well DBW-17. The temperature profile from the interval $320-385 \mathrm{~m}(1050-1263 \mathrm{ft})$ of the bottom part of this well yields an approximate thermal gradient of $70^{\circ} \mathrm{C} / \mathrm{km}\left(3.9^{\circ} \mathrm{F} / 100 \mathrm{ft}\right)$.
\end{abstract}

\section{Introduction}

This report supports efforts by the Idaho National Laboratory and the U.S. Department of Defense to investigate the geothermal resource potential of the Utah Test and Training Range (UTTR) located in Tooele and Box Elder Counties of northwestern Utah. On 22 and 23 June 2011, geologists from the Utah Geological Survey (UGS) measured down-hole temperatures in six inactive brine production wells at a facility near Wendover, Utah operated by Intrepid Potash, Inc. Intrepid produces brine from a number of both shallow and deep brine wells for potash and other salt extraction. Turk (1973) presents data on 13 "deep brine wells" drilled to depths ranging from $326-631 \mathrm{~m}(1070-2070 \mathrm{ft})$. The highest temperature recorded was $88^{\circ} \mathrm{C}\left(190^{\circ} \mathrm{F}\right)$, measured in the (bailed) drilling mud of one well designated as "DBW-3" at a depth of $499 \mathrm{~m}(1637 \mathrm{ft})$. The brine produced from these deep wells contains $120,000-130,000 \mathrm{mg} / \mathrm{L}$ total dissolved solids.

Hydrothermal systems indicated by thermal springs and wells are scattered throughout this large, sparsely populated region of Utah. The region extends westward from the Cedar Mountains in central Tooele County across the Bonneville Salt Flats to the Nevada-Utah state line, and then southward into Snake and Tule Valleys of Juab and Millard Counties. Mundorff (1970) included information on thermal springs and general geology for the Great Salt Lake Desert and western Utah as part of his report on major thermal springs in the state. Turk (1973) noted abnormally high geothermal gradients in brackish water wells, several deep brine wells, and two warm springs in the Bonneville Salt Flats area. Blue Lake and Salt Spring, located in western Tooele County near the Utah-Nevada border, are small lakes fed by thermal springs. Blue Lake maintains a fairly constant temperature at about $29^{\circ} \mathrm{C}\left(84^{\circ} \mathrm{F}\right)$, although during a watersampling exercise in September 2011, we measured temperatures of about $28^{\circ} \mathrm{C}\left(82^{\circ} \mathrm{F}\right)$. Whelan and Petersen (1974) focused a brief report on the geothermal potential of the Bonneville Salt 
Flats, referencing the work of Turk. Goode (1978) also reported on thermal springs in this region as part of an overall study of thermal waters in Utah.

Whelan and Petersen (1974) discuss the relationship of the location and depths of the deep brine wells with respect to the Wendover Graben (see Figure B-1). As suggested by Cook and others (1964), this graben trends southwest-northeast parallel to the Silver Island Range to the north. The graben is more than $56 \mathrm{~km}(35 \mathrm{mi})$ long and at least $16 \mathrm{~km}(10 \mathrm{mi})$ in maximum width. Beneath the salt crust, the graben is filled with lacustrine sediments underlain by fluvial sediments. At about $366 \mathrm{~m}$ (1200 ft), the deep brine wells described by Turk (1973) penetrated "hard rock" or "conglomerate" that Whelan and Petersen (1974) suggest may be volcanic breccia corresponding to volcanic rocks in the Silver Island Range.

\section{Temperature Profiles}

Russ Draper of Intrepid Potash's Wendover, Utah facility provided UGS geologists with access to six of Intrepid's unused deep-brine wells. Temperature profiles (see Figure B-2) were recorded by UGS personnel (R. Blackett, M. Gwynn, and A. Rupke) using a high-precision thermistor probe and temperature logging equipment. The equipment consists of a thermistor probe linked to four-conductor cable on a reel in connection with a volt-ohm meter. Probe resistance is read from the volt-ohm meter, manually recorded and converted to temperature using a probe-specific polynomial determined by the manufacturer (Natural Progression Instruments, Olympia, Washington). Instrument characteristics and periodic calibrations result in a temperature measurement precision of $0.01^{\circ} \mathrm{C}\left(0.02^{\circ} \mathrm{F}\right)$. Temperatures were recorded at $5-\mathrm{m}$ (16-ft) intervals in the six deep brine wells with a total of $1130 \mathrm{~m}(3706 \mathrm{ft})$ of borehole length recorded. Bottom-hole temperatures ranged from 15 to $44^{\circ} \mathrm{C}\left(59\right.$ to $\left.111^{\circ} \mathrm{F}\right)$ in boreholes ranging from 85 to $410 \mathrm{~m}$ (279 to $1345 \mathrm{ft}$ ) depth (see Table B-1). All wells were completed with surface casing of approximately $43 \mathrm{~cm}$ (17-in) diameter with a production casing of about $18.4 \mathrm{~cm}$ (7.25-in) diameter. Shallow temperatures recorded above the static water levels (in air) depict negative thermal gradients downward to the static water level in all wells. Below the static water level (in most cases) temperature-depth profiles reverse becoming positive.

Table B-1. Summary of Intrepid Potash's “deep brine wells" near Wendover, Utah. Temperature profiles were measured in June 2011.

\begin{tabular}{|l|l|l|l|l|r|r|r|r|}
\hline \multicolumn{1}{|c|}{ Name } & Latitude & Longitude & Location & Datum & Elev. $(\mathbf{m})$ & Date & Depth (m) & Bht $\left({ }^{\circ} \mathbf{C}\right)$ \\
\hline 1-2 Harvest & 40.7237 & -113.9797 & $(\mathrm{C}-01-19) 23 \mathrm{cbc}$ & NAD83 & 1286.0 & $6 / 22 / 2011$ & 90.0 & 15.0 \\
\hline DBW8 & 40.6834 & -113.9955 & $(\mathrm{C}-02-19) 03 \mathrm{bcd}$ & NAD83 & 1285.0 & $6 / 23 / 2011$ & 240.0 & 24.2 \\
\hline DBW14A & 40.6770 & -113.9791 & $(\mathrm{C}-02-19) 02 \mathrm{ccc}$ & NAD83 & 1285.0 & $6 / 22 / 2011$ & 200.0 & 21.6 \\
\hline DBW17 & 40.6569 & -113.9654 & $(\mathrm{C}-02-19) 14 \mathrm{adb}$ & NAD83 & 1285.0 & $6 / 22 / 2011$ & 410.0 & 43.9 \\
\hline DBW22 & 40.6907 & -113.9914 & $(\mathrm{C}-01-19) 34 \mathrm{cdd}$ & NAD83 & 1285.0 & $6 / 23 / 2011$ & 105.0 & 16.4 \\
\hline DBW23 & 40.7040 & -113.9861 & $(\mathrm{C}-01-19) 34 \mathrm{aba}$ & NAD83 & 1285.0 & $6 / 23 / 2011$ & 85.0 & 15.2 \\
\hline
\end{tabular}


The following paragraphs summarize the temperature logging within Intrepid's deep brine wells. The locations of the wells are shown on Figure B-1. Russ Draper (Intrepid) reported that he thought that all of the wells were originally completed to about $400 \mathrm{~m}$ (1300 ft). However, since the wells had not been used in a number of years, we found that only DBW-17 was open to the original total depth of about $410 \mathrm{~m}(1345 \mathrm{ft})$.

1-2 Harvest: A blockage was encountered in this well at $90 \mathrm{~m}$ (295 ft) depth, stopping the temperature probe. The bottom-hole temperature $(\mathrm{BHT})$ recorded was $15.0^{\circ} \mathrm{C}\left(59^{\circ} \mathrm{F}\right)$. The temperature profile is nearly isothermal to probe depth. A driller's log was not available for this well. Static water level was $11.7 \mathrm{~m}$ (38.4 ft) depth.

$\underline{D B W-8:}$ : Temperatures in this well were measured to $240 \mathrm{~m}(787 \mathrm{ft})$ where a blockage was encountered. The bottom-hole temperature (BHT) was $24.2^{\circ} \mathrm{C}\left(75.5^{\circ} \mathrm{F}\right)$. The thermal gradient between $100-200 \mathrm{~m}(328-656 \mathrm{ft})$ is about $57^{\circ} \mathrm{C} / \mathrm{km}\left(3.13^{\circ} \mathrm{F} / 100 \mathrm{ft}\right)$. Turk (1973) shows a driller's log for DBW-8 extending to $343 \mathrm{~m}(1126 \mathrm{ft})$ depth, encountering alternating layers of clay and gypsum to a depth of about $283 \mathrm{~m}(930 \mathrm{ft})$. At this depth, the drillers encountered mainly "gravel" and "conglomerate." Static water level was at a depth of $14.3 \mathrm{~m}(46.9 \mathrm{ft})$.

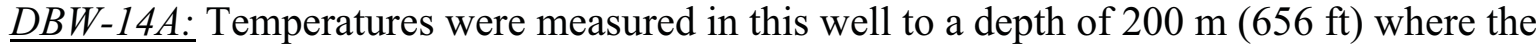
probe became stuck. The profile reveals a conductive gradient from about $50 \mathrm{~m}(164 \mathrm{ft})$ to about $200 \mathrm{~m}(656 \mathrm{ft})$ depth where a temperature of $21.6^{\circ} \mathrm{C}\left(70.8^{\circ} \mathrm{F}\right)$ was measured. A driller's $\log$ was not available for this well. Static water level was $7.25 \mathrm{~m}$ (23.8 ft) depth.

$D B W-17$ : Temperatures were measured in DBW-17 to $410 \mathrm{~m}$ (1345 ft), where the BHT was $43.9^{\circ} \mathrm{C}\left(111^{\circ} \mathrm{F}\right)$. A drillers log was not available for this well, however, DBW-17 is near DBW-1, which was completed in 1943 (Turk, 1973) to a depth of $366 \mathrm{~m}$ (1200 ft). DBW-1 reportedly encountered mostly clay, gypsum, and sand to $356 \mathrm{~m}$ (1168 ft), apparently entering black volcanic rock at that depth. The temperature profile from the interval $320-385 \mathrm{~m}(1050-1263 \mathrm{ft})$ of the bottom part of the well yields an approximate thermal gradient of $70^{\circ} \mathrm{C} / \mathrm{km}\left(3.9^{\circ} \mathrm{F} / 100 \mathrm{ft}\right)$. Static water level was $26.5 \mathrm{~m}(86.9 \mathrm{ft})$ depth. Changes in thermal gradients above the valleyfill/bedrock contact (about $350 \mathrm{~m}$ ) may be due to higher thermal-conductivity layers of salt interbedded with lower thermal-conductivity layers of clay and silt.

$D B W-22$ : A blockage was encountered in this well at about $105 \mathrm{~m}(345 \mathrm{ft})$ depth where a BHT of $16.4^{\circ} \mathrm{C}\left(61.6^{\circ} \mathrm{F}\right)$ was measured. The temperature profile to that depth was nearly isothermal. Static water level was $15.5 \mathrm{~m}(50.9 \mathrm{ft})$ depth.

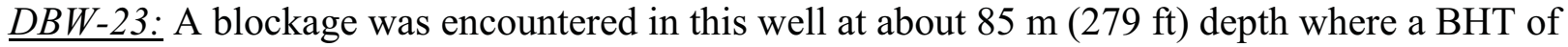
$15.2^{\circ} \mathrm{C}\left(59.4^{\circ} \mathrm{F}\right)$ was measured. The temperature profile to that depth was nearly isothermal. Static water level was $8.1 \mathrm{~m}(26.6 \mathrm{ft})$ depth.

Whelan and Petersen (1974) describe the lithologies penetrated in Shell Oil Salduro \#1 exploratory well drilled in 1956 (see Figure B-1). The well was drilled to $900 \mathrm{~m}$ (2950 ft) penetrating typical lacustrine clay, gypsum, and limestone to about $410 \mathrm{~m}(1350 \mathrm{ft})$. From this point the well continued through "conglomerate" to $490 \mathrm{~m}$ (1610 ft), followed by a sequence of "volcanic breccia" with alternating beds of clay/tuff. The well then entered basalt at about $835 \mathrm{~m}$ $(2740 \mathrm{ft})$. "Microgabbro" was described at $863 \mathrm{~m}(2830 \mathrm{ft})$ and the well was bottomed in dark igneous rock described as "olivine augite diabase". Records from the Utah Division of Oil, Gas, and Mining (DOGM) indicate an uncorrected maximum recorded temperature (or BHT) of $56^{\circ} \mathrm{C}$ $\left(133^{\circ} \mathrm{F}\right)$ for the Salduro \#1 well and $68^{\circ} \mathrm{C}\left(154^{\circ} \mathrm{F}\right)$ for the Alpha Gov't \#1 well. Corrected BHTs 
of $61^{\circ} \mathrm{C}\left(142^{\circ} \mathrm{F}\right)$ at $899 \mathrm{~m}(2950 \mathrm{ft})$ and $73^{\circ} \mathrm{C}\left(163^{\circ} \mathrm{F}\right)$ at $1302 \mathrm{~m}(4720 \mathrm{ft})$ were computed for the Salduro \#1 and Alpha Gov’t \#1 wells, respectively (M. Gwynn, written communication, November 2011). See the plotted values on Figure B-2. Note that these corrected BHTs are rough estimates by adding $5^{\circ} \mathrm{C} / \mathrm{km}\left(0.27^{\circ} \mathrm{F} / 100 \mathrm{ft}\right)$ to the uncorrected value, considering typical conditions. No information about bottom-hole mud circulation times (time when the temperature measurement was recorded versus time when circulation stopped) was available on the log headers. We estimate the uncertainty associated with these corrected temperatures at $\pm 5^{\circ} \mathrm{C}$.

\section{Summary}

Based on temperature profiles from six deep brine wells located on Intrepid Potash's property near Wendover, Utah, subsurface temperatures appear elevated and suggest that hydrothermal fluids circulate to relatively shallow depths, possibly along faults marginal to the Wendover graben. A down-hole temperature of $88^{\circ} \mathrm{C}\left(190^{\circ} \mathrm{F}\right)$ at $499 \mathrm{~m}(1637 \mathrm{ft})$ was reported by Turk (1973) in well DBW-3, located less than $5 \mathrm{~km}(3 \mathrm{mi})$ west of the southern tract of the UTTR. Down-hole temperature data from other deep brine wells owned by Intrepid Potash also suggest that temperatures appear to increase southeastward toward the west side of the southern tract of the UTTR. The highest temperature recorded in wells measured as part of this study was a bottom-hole temperature of $43.9^{\circ} \mathrm{C}\left(111^{\circ} \mathrm{F}\right)$ measured at $410 \mathrm{~m}(1345 \mathrm{ft})$ depth in well DBW-17. The temperature profile from the interval 320-385 m (1050-1263 ft) of the bottom part of the well yields an approximate thermal gradient of $70^{\circ} \mathrm{C} / \mathrm{km}\left(3.9^{\circ} \mathrm{F} / 100 \mathrm{ft}\right)$.

\section{References}

Cook, K. L., M. O. Halverson, J. C. Stepp, and J. W. Berg, Jr., 1964, "Regional Gravity Survey of the Northern Great Salt Lake Desert and Adjacent Areas in Utah, Nevada, and Idaho," Geol. Soc. Am. Bull., 75, 715-740.

Goode, H. D., 1978, Thermal Waters of Utah, Utah Geological and Mineral Survey Report of Investigation \#129.

Mundorff, J. C., 1970, Major Thermal Springs of Utah, Utah Geological and Mineralogical Survey Water-Resources Bulletin \#13.

Turk, L. J., 1973, Hydrogeology of the Bonneville Salt Flats, Utah Geological and Mineral Survey Water Resources Bulletin \#19.

Whelan, J. A., and C. A. Petersen, 1974, "Bonneville Salt Flats-A Possible Geothermal Area?," Utah Geology, 1(1), 71-82. 


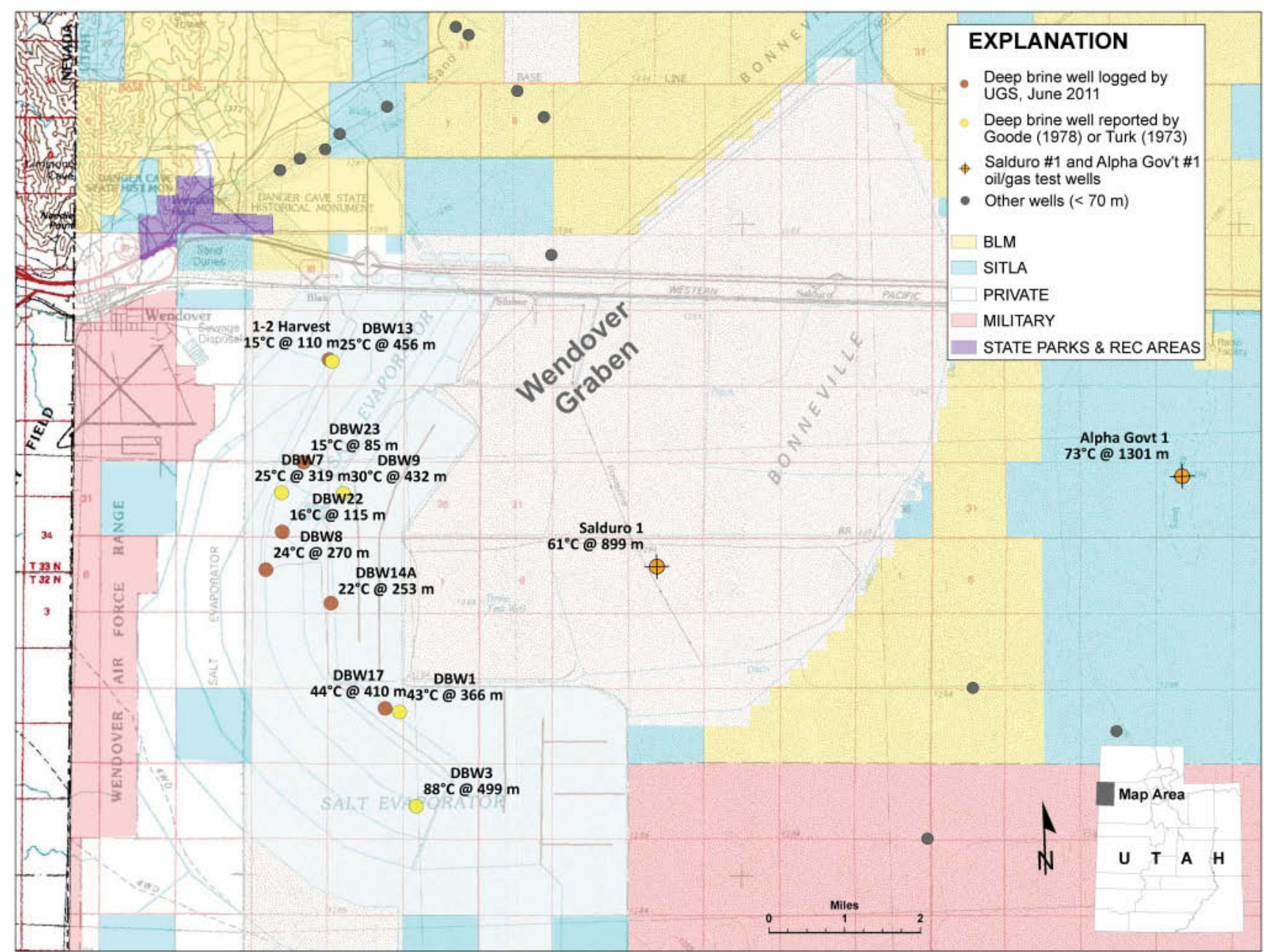

Figure B-1. Map showing locations of deep brine wells and other wells at Intrepid Potash, Inc.

Wendover, Utah operations. (Note: the federal government has retained the mineral rights to much of the private land depicted in this figure.) 


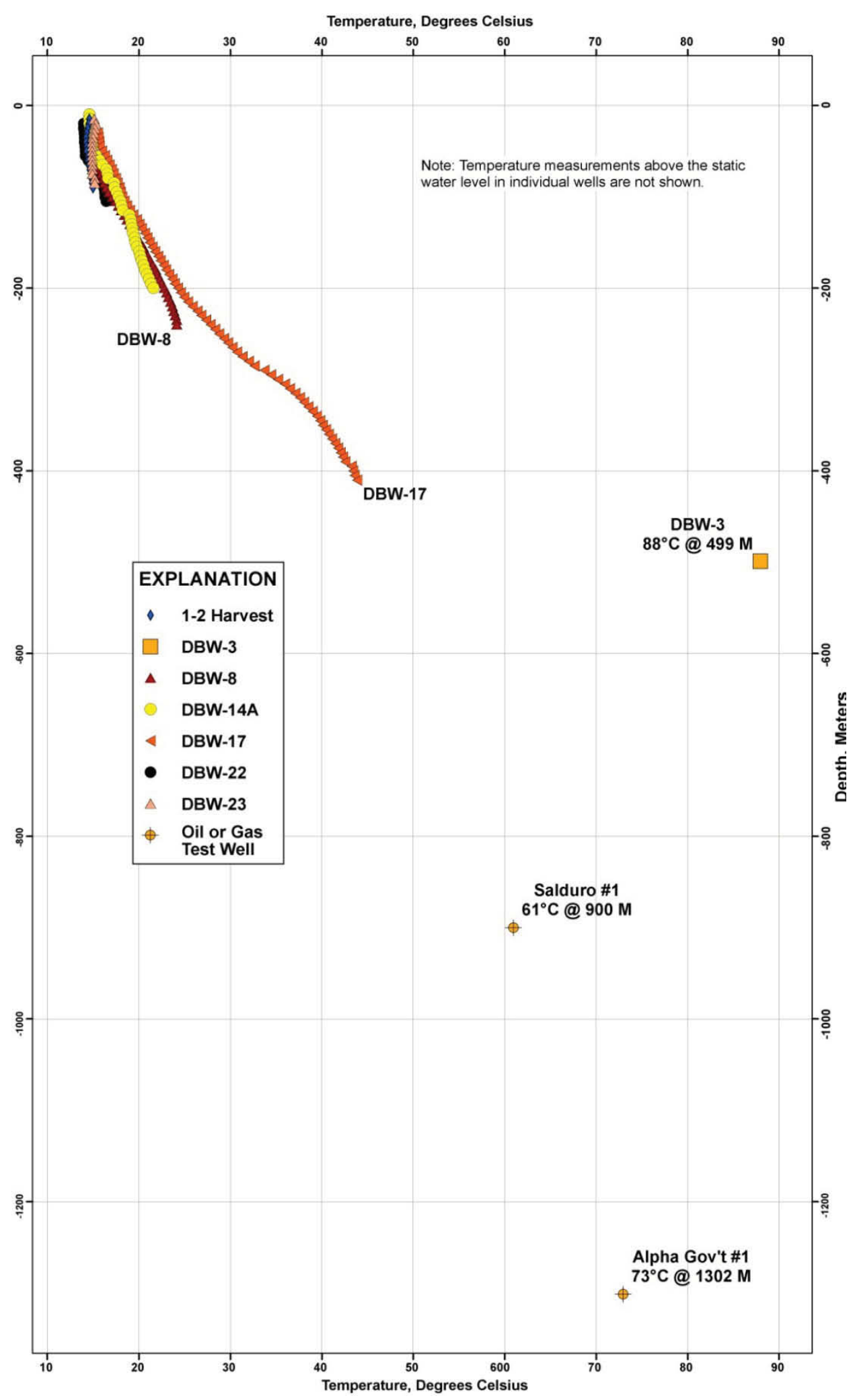

Figure B-2. Temperature-depth profiles of some of Intrepid Potash, Inc. deep brine wells near Wendover, Utah. Profiles measured by UGS personnel on 22 and 23 June 2011. Reported BHT value for DBW-3 (Turk, 1974), and corrected BHT values for the Shell Oil Salduro \#1 and the Alpha Gov't \#1 oil/gas exploratory wells are shown for reference. 


\title{
Appendix C
}

\section{Lineament Study}

\author{
Clay Grant Jones ${ }^{1}$, Richard Smith ${ }^{2}$, Beth Murphy ${ }^{1}$, and Greg Nash ${ }^{1}$ \\ ${ }^{1}$ Energy and Geoscience Institute \\ ${ }^{2}$ Smith Geologic and Photographic Services
}

\section{Introduction}

Fault/lineament mapping on Hill Air Force Base Bombing-Range was done using high resolution NAIP (National Agricultural Imagery Program) imagery as a mapping base. Mapping was done using ESRI ArcGIS 10.0 producing an output shapefile (see Figure C-1). The NAIP imagery helped in the identification of linear vegetation anomalies and aligned springs that are generally related to faults.

ArcGIS Explorer was used to visualize the imagery in 3-D (Figure C-2). This helped facilitate the identification of geomorphic features that are related to faults such as rotated blocks and faceting along range-fronts.

Field work was conducted on October 25 and 26, 2011, to validate faults and lineaments mapped from imagery. When discussing particular fault lineaments reference will be made to the numbers shown in Figure C-3.

\section{Lineaments 1 and 2}

Expressions of lineaments 1 and 2 were not observed. The area was traversed multiple times in zig-zag pattern via truck in an attempt to locate any linear features. The area was covered by light colored mud and randomly interspersed vegetation, and cut by several shallow dry washes with meandering to braded channels in a direction parallel to sub- parallel with the lineaments in Figure 3. These channels may represent the surface expression of a concealed fault or faults. However, the physical evidence is weak.

\section{Lineaments 3 to 6}

Lineaments 3, 4, 5 and 6 are in the vicinity of a spring known as Mosquito Willey's. Spring fed pools were found at 2 locations. The northern spring (see Figures C-4 and C-7) was warm to the touch. The southern spring was found to be at roughly ambient temperature (day time high on Oct $25 \sim 50^{\circ} \mathrm{F}$ ). Outcrops immediately to the west of these two springs consisted of brecciated limestone cemented by secondary calcite (see Figure C-5), with minor hematite staining. The outcrop is draped by a calcite cemented conglomerate (see Figure C-6), which consists of poorlysorted and angular limestone clasts up to several feet in diameter, many of which are also brecciated. This may have been a deposit derived from the footwall of a normal fault scarp cemented by calcite precipitating from spring waters discharging into paleo Lake Bonneville. Near where the springs emanate there are thin (a couple of feet thick) white, botryoidal calcite deposits (see Figure C-7). These springs and the outcrop are located roughly between the southern termination of lineament \#3 and the northern extension of \#5. 
No expression of lineament \#3 could be seen from the top of the outcrop west of Mosquito Willey's. Several sandy mounds that appeared to trend to the N-to-NE in roughly the same direction as mapped lineament \#3 are present, but these are likely to be lakeshore or aeolian deposits (see Figure C-8).

No surface expression was found of lineament \#4, which is mapped as bisecting a NW-SE trending topographic feature, on the SE edge of which is Mosquito Willey's (see Figure C-9). The lineament runs perpendicular to this feature, but offset was observed in the outcrop.

A limestone outcrop was investigated in the vicinity of lineament \#5, south of Mosquito Willey's. Here limestone beds with brown chert nodules dip nearly $90^{\circ}$. Outcrops near Mosquito Willey's (between the southern termination of lineament \#3 and the northern extension of \#5, as above) had nearly horizontal bedding. This outcrop is extensively brecciated, but less so at than Mosquito Willey's. Several shear zones (see Figure C-10) were observed as well as botryoidal calcite deposits (see Figure C-11).

Lineament \#6 followed the base of a NW-to-SE trending fin of limestone (see Figures C-12 and C-13). Areas of intense brecciation were observed in the limestone (see Figures C-14 and C-15). Botryoidal calcite deposits, most likely consisting of Lake Bonneville tufa, were seen filling fractures and coating the entire outcrop from base to top (see Figures $\mathrm{C}-16$ and $\mathrm{C}-17$ ). To the NE of the limestone fin there was a break in slope that could potentially be due to faulting; alternatively it could be an eroded paleo lake terrace (see Figure C-13).

\section{Lineament 7}

Lineament \#7 trends SW-to-NE. Near the lineaments NE end it crosses in front of a mesa with a large planar face (see Figure C-18), which appears to be roughly parallel with the lineament. The lineament was crossed twice on a dirt road which stayed within several hundred meters of the mapped lineament for about two kilometers. No linear break in slope was observed. The area is covered by lake deposits. There was a vegetation change which roughly followed the same trend. The vegetation change was marked by grass on the NW to brush on the SE (see Figure C-19).

\section{Lineament 8}

Lineament \#8 crosses a saddle between two topographic highs (see Figure C-20). A paleo lake shore can be correlated from one side to the other, indicating that there hasn't been any offset in the recent past (see Figure C-21). In addition, it appears that a thick band of limestone can be correlated across the saddle, consistent with the conclusion that there is no offset across the lineament.

\section{Lineaments 9 and 10}

Lineament \#9 follows the northern and eastern edges of a topographic feature called Rocky Point (see Figure C-22). Lineament \#10 cuts through a saddle roughly perpendicular to lineament \#9 (see Figure C-23). There is no offset of the lake shore terrace between the topographic highs to either side of the saddle, and a thicker band of limestone outcrops above the terrace on both sides suggesting that there has been little to no movement. Limestone outcrops on the lower reaches of rocky point were extensively brecciated (see Figure C-24) and sheared. 
Botryoidal calcite deposits were observed filling fractures as well as deposited on the exterior of the limestone outcrops. Minor calcite cemented conglomerate deposits composed of locally derived limestone clasts were also observed (see Figure C-25).

\section{Lineament 11}

Lineament \#11 cut across some low foothills (see Figure C-26). No linear trending topographic feature was observed, and the outcrops examined near the mapped lineament showed little to no evidence of tectonic influence (see Figure C-27). However, this fault is present in the U.S.G.S. Quaternary fault database and labeled as "Unnamed fault zone in Ferber Hills."

\section{Lineament 12}

No expression of lineament \#12 was observed in a bicycle traverse of the area from west to east and back again. Lineament \#13was not checked. The area was fairly densely vegetated but also very flat (see Figure C-28). A vegetation anomaly (vegetation on one side but not the other) is seen on the NAIP imagery along the northern part of lineament \#12. Changes in drainage direction are also present along these lineaments, although not consistently.

\section{Lineaments 13-22 Not Examined}

These areas were not examined due to time (\#19-\#22), vehicle (\#14) and access (\#15-\#18) constraints. 


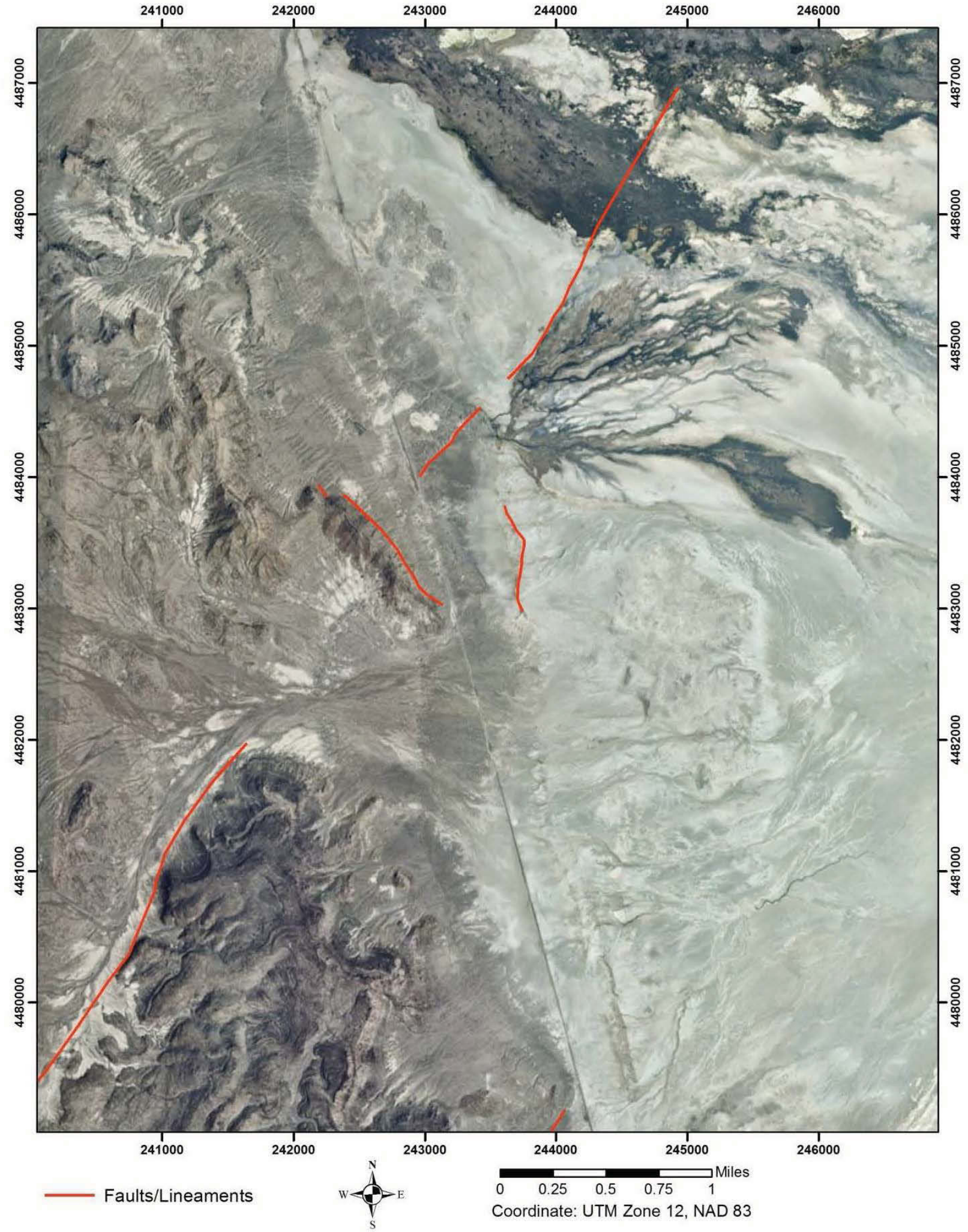

Figure C-1. NAIP image overlain with faults/lineaments in the Blue Lake area south of Wendover, Utah. 


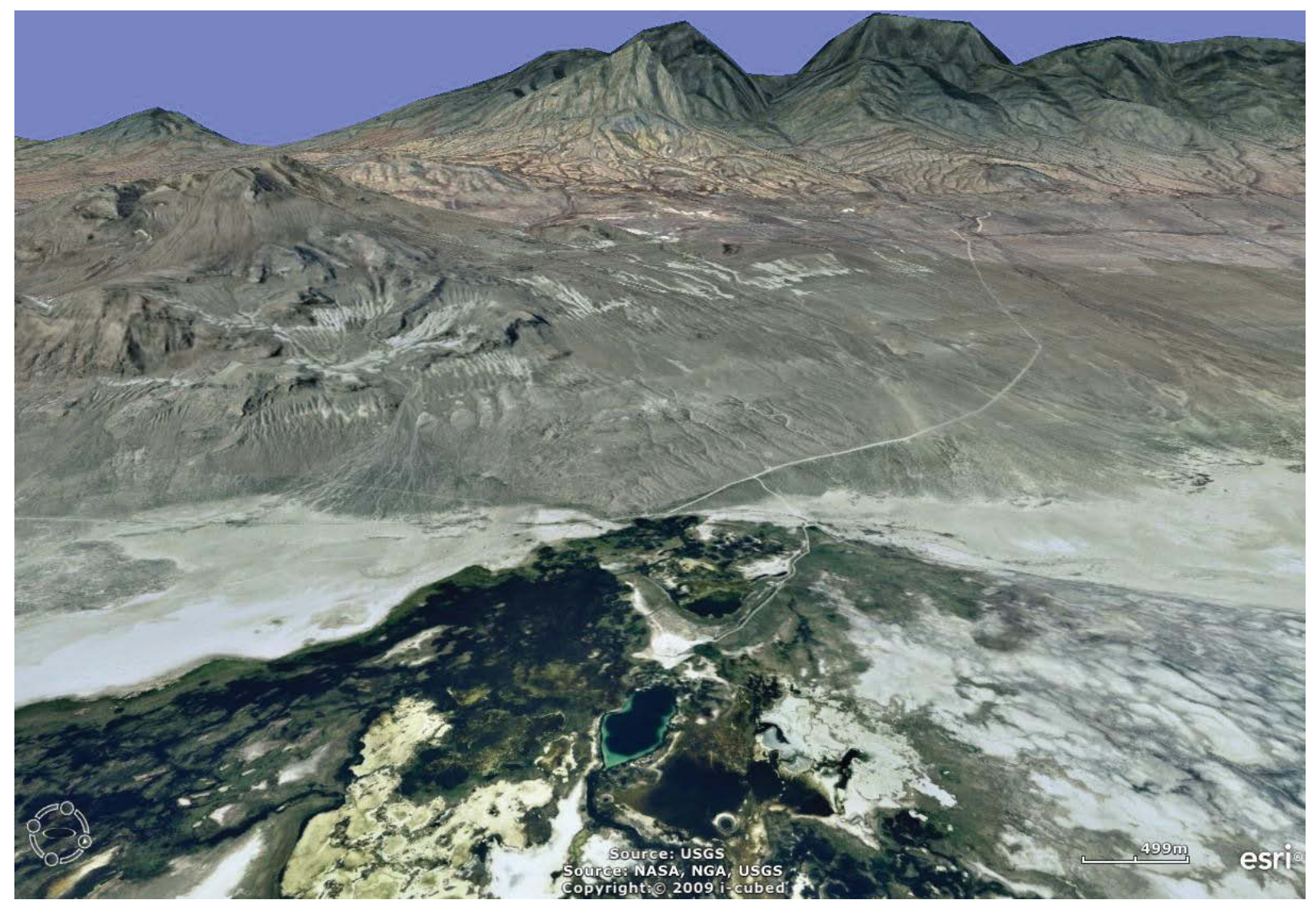

Figure C-2. 3-D rendering of the Blue Lake area from ArcGIS Explorer. 


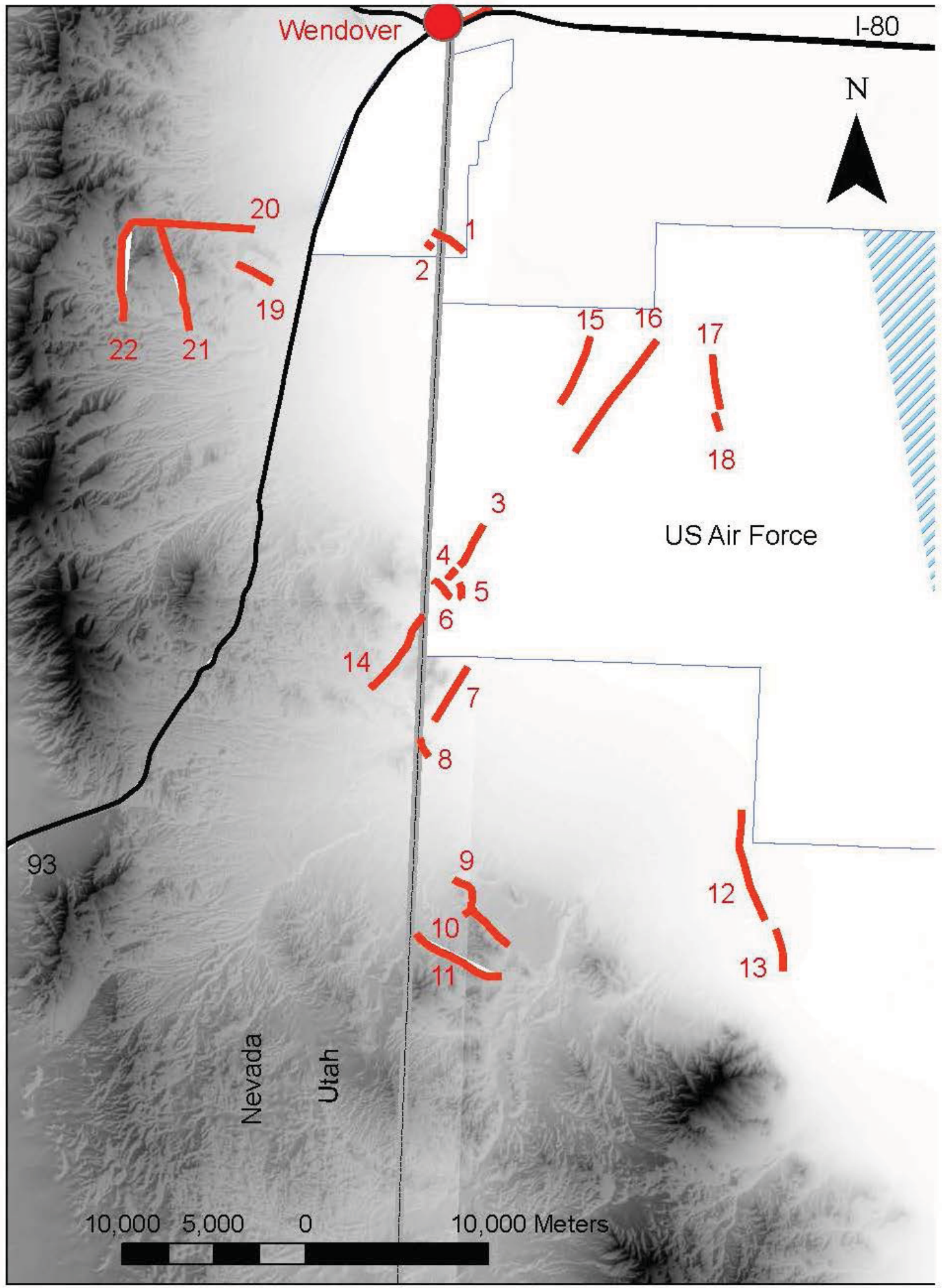

Figure C-3. Map of study area. Hill shaded digital elevation model displays topographic lows as white and highs as black. US Air Force property is cross-hatched in blue. Major roads, I-80 and Nevada State Road 93 are displayed as black lines. The location of the towns of Wendover, Utah and Nevada are marked with a red circle. Fault lineaments are shown as red lines, with corresponding red numbers. See text for a discussion of the lineaments. 


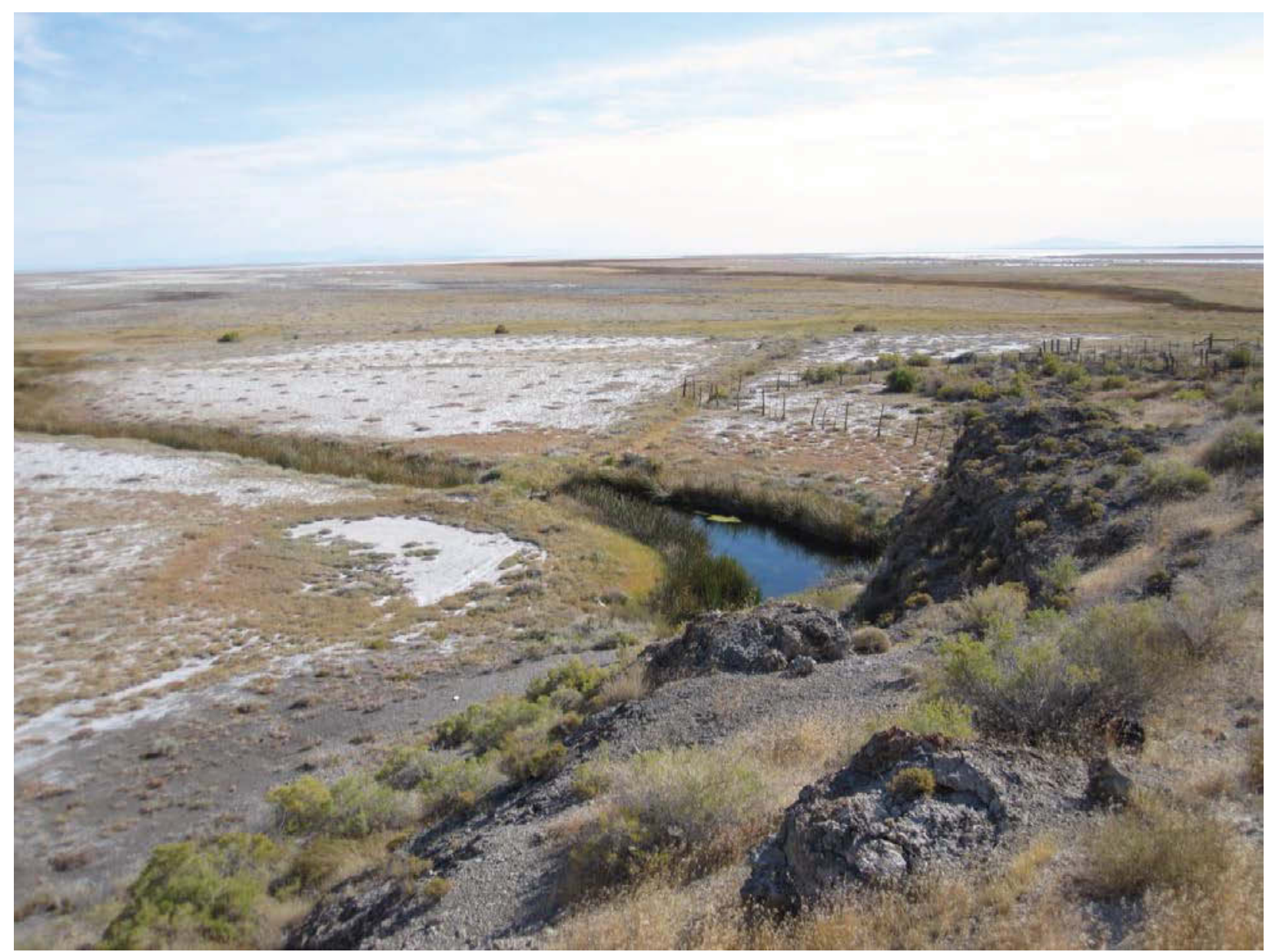

Figure C-4. Northern warm spring fed pool at Mosquito Willey's. Vegetation in the upper left portion of the picture shows the path taken by the waters emanating from the southern spring. 


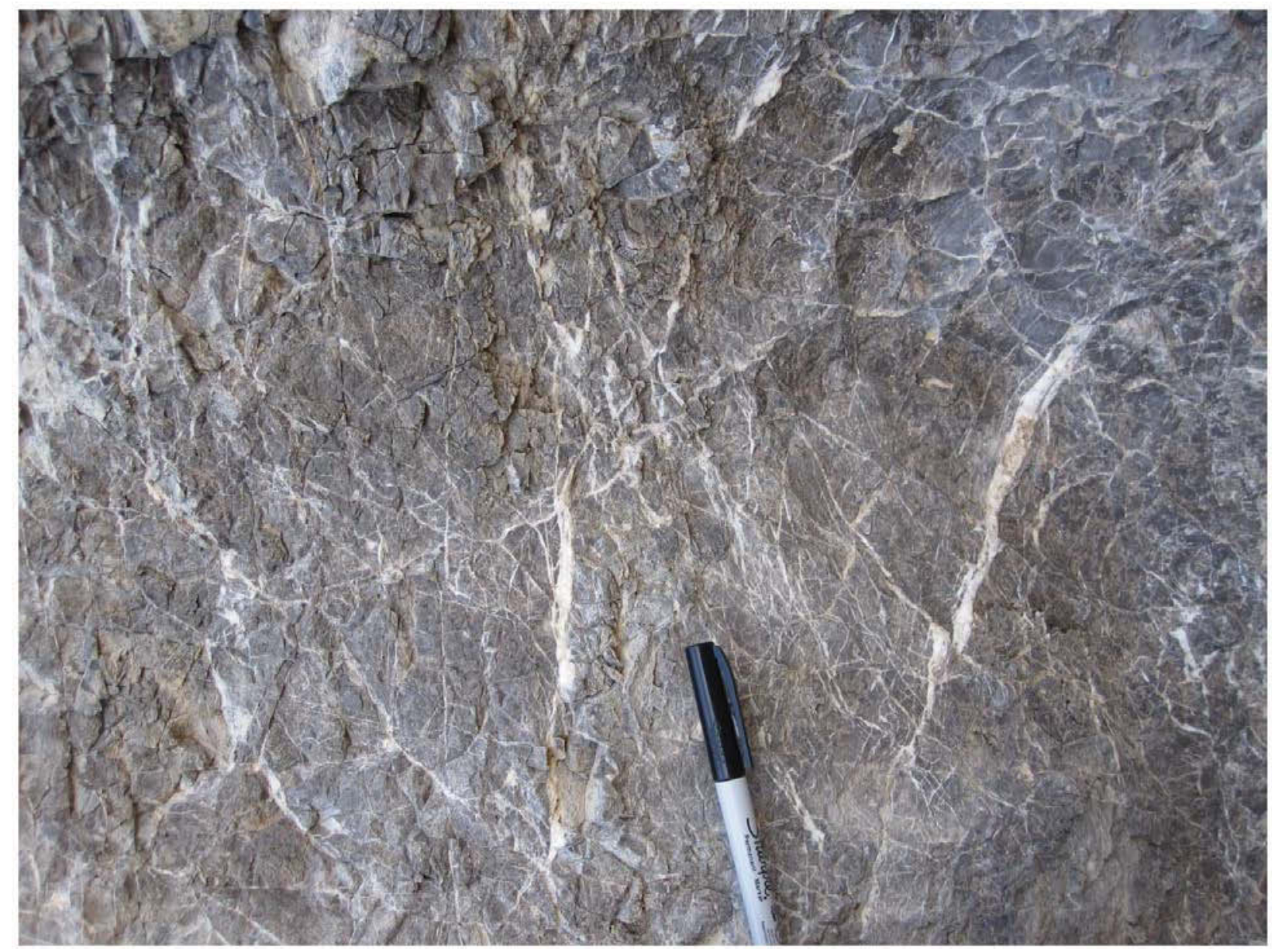

Figure C-5. Extensively brecciated limestone cut by a dense network of calcite veins near the warm spring at Mosquito Willey's. 


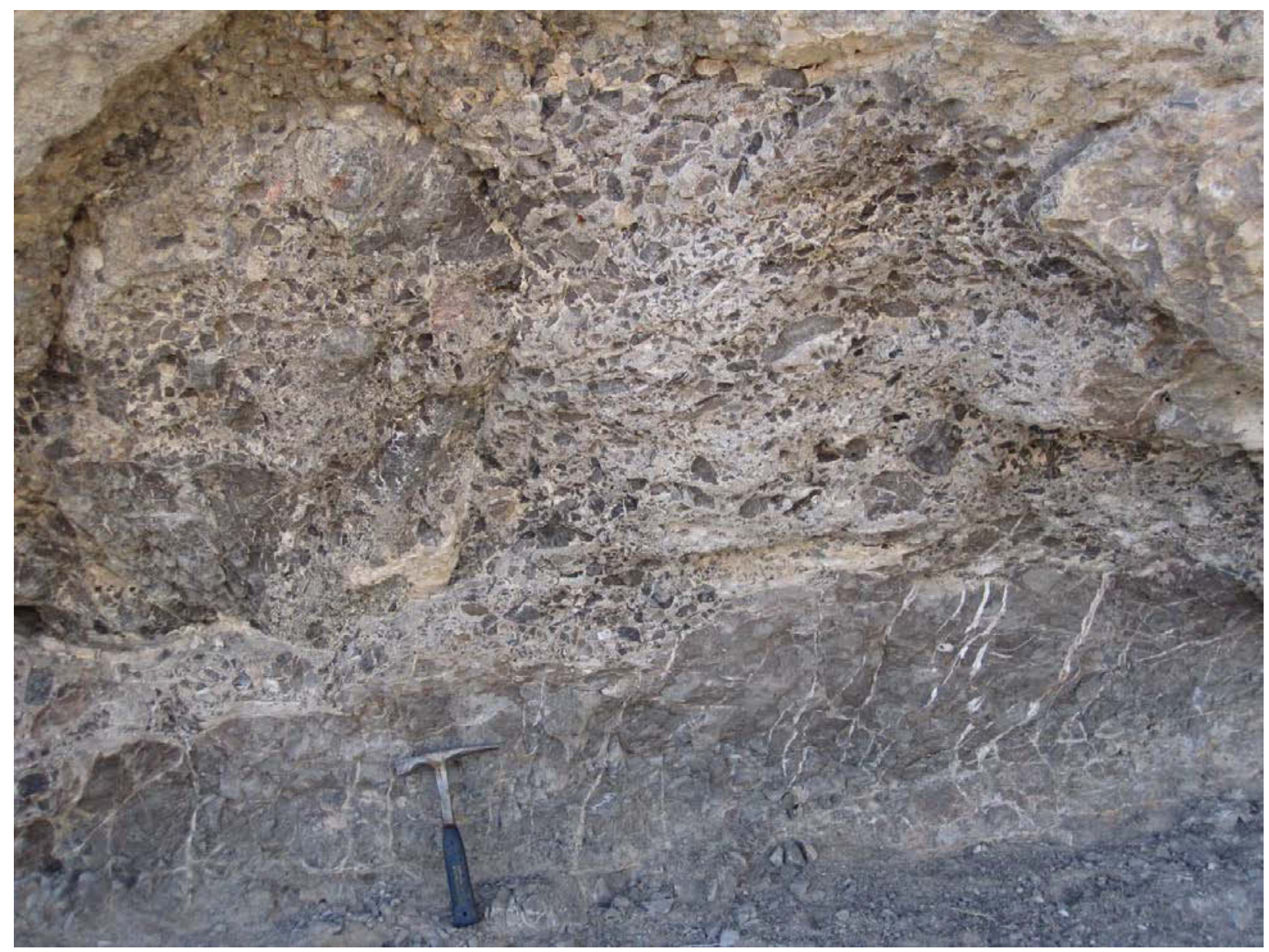

Figure C-6. Calcite cemented conglomerate composed of locally derived limestone clasts deposited on a brecciated limestone outcrop cut by calcite veins. This outcrop is located to the photographers left in Figure C-2. 


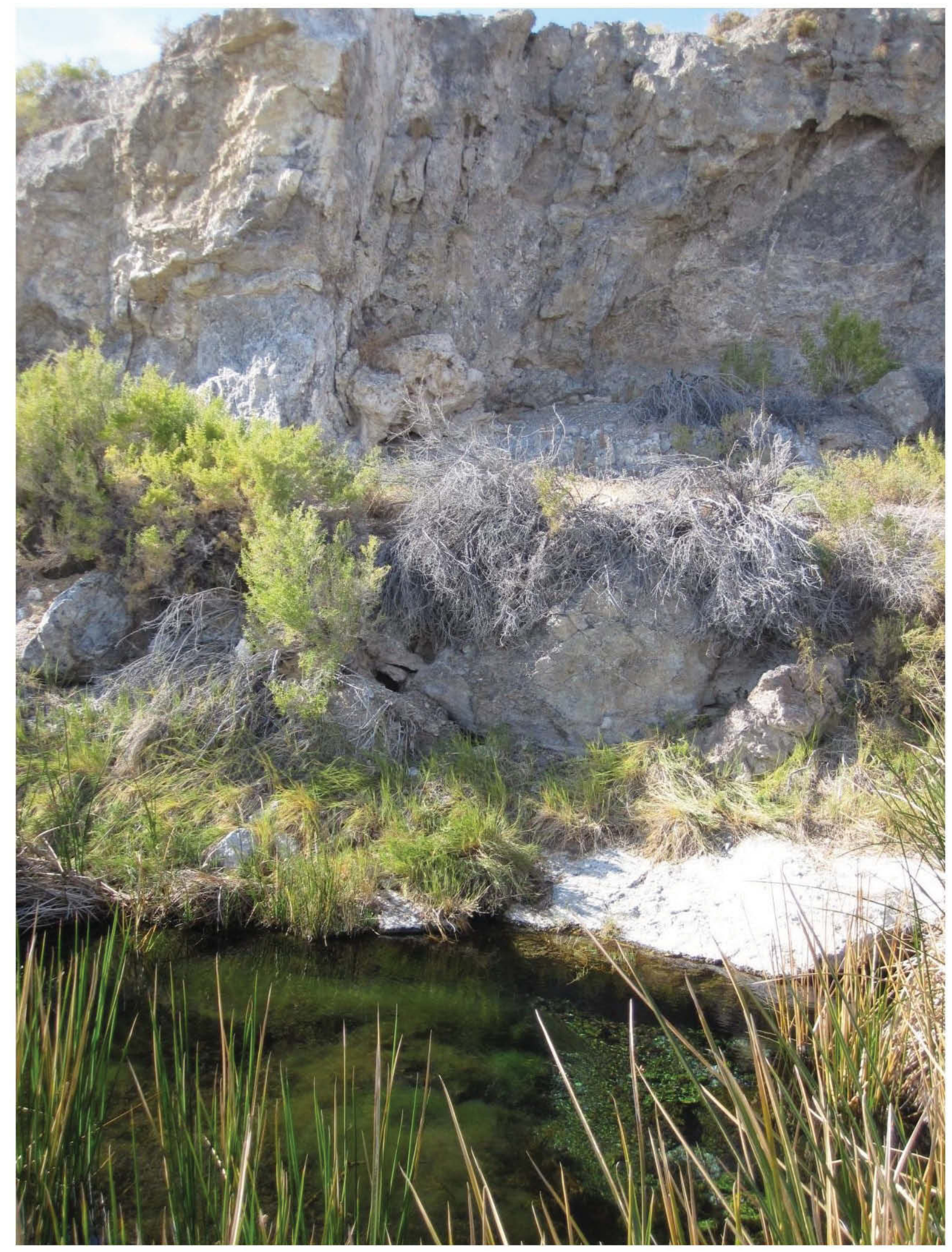

Figure C-7. White botryoidal calcite deposit adjacent to the northern warm spring at Mosquito Willey's. 


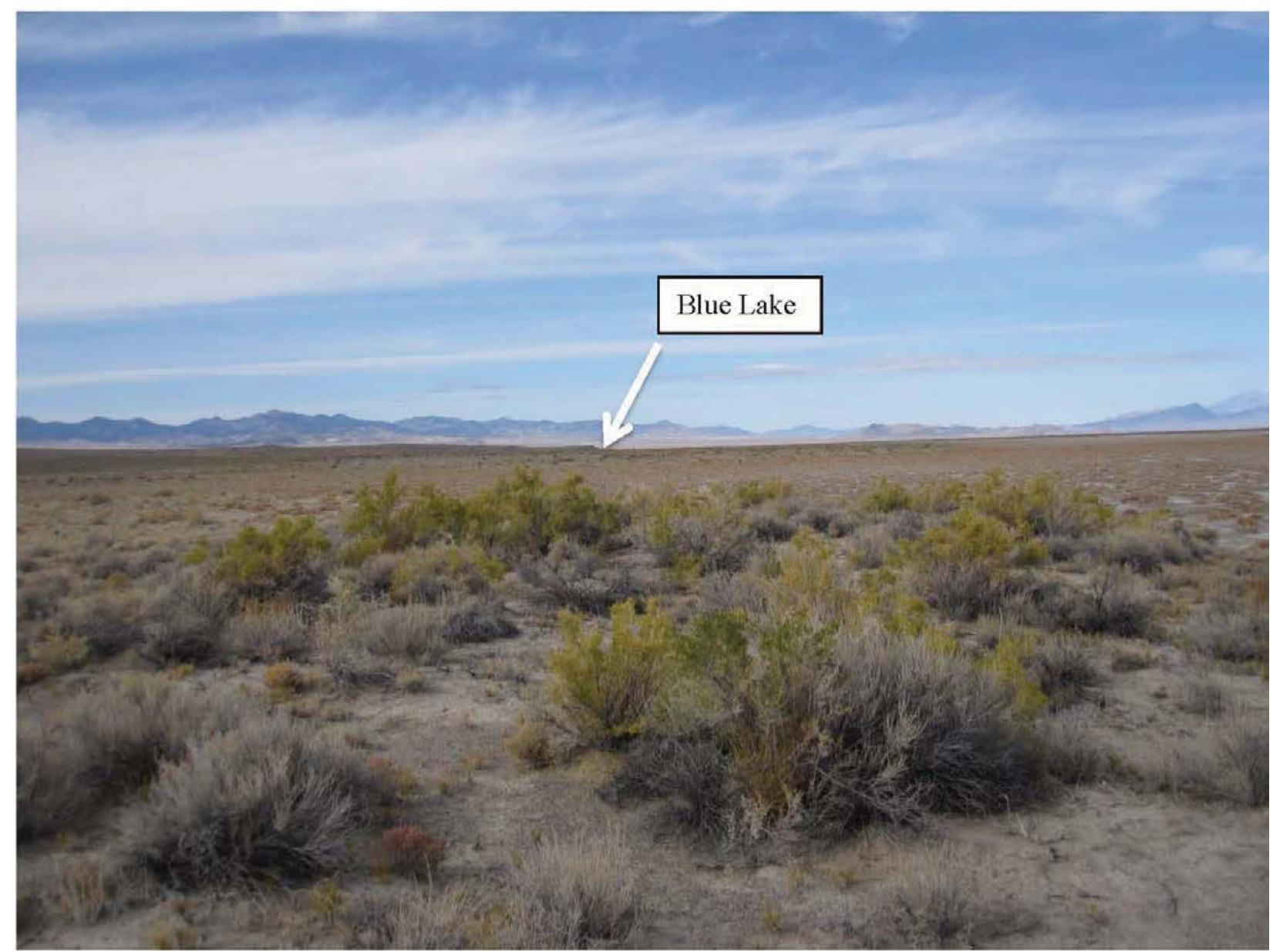

Figure C-8. Looking to the $\mathrm{N}$ from the vicinity of lineament \#3. The terrain is relatively flat although a few low sandy hills are present. Springs feeding Blue Lake discharge at the break in slope indicated by the white arrow. 


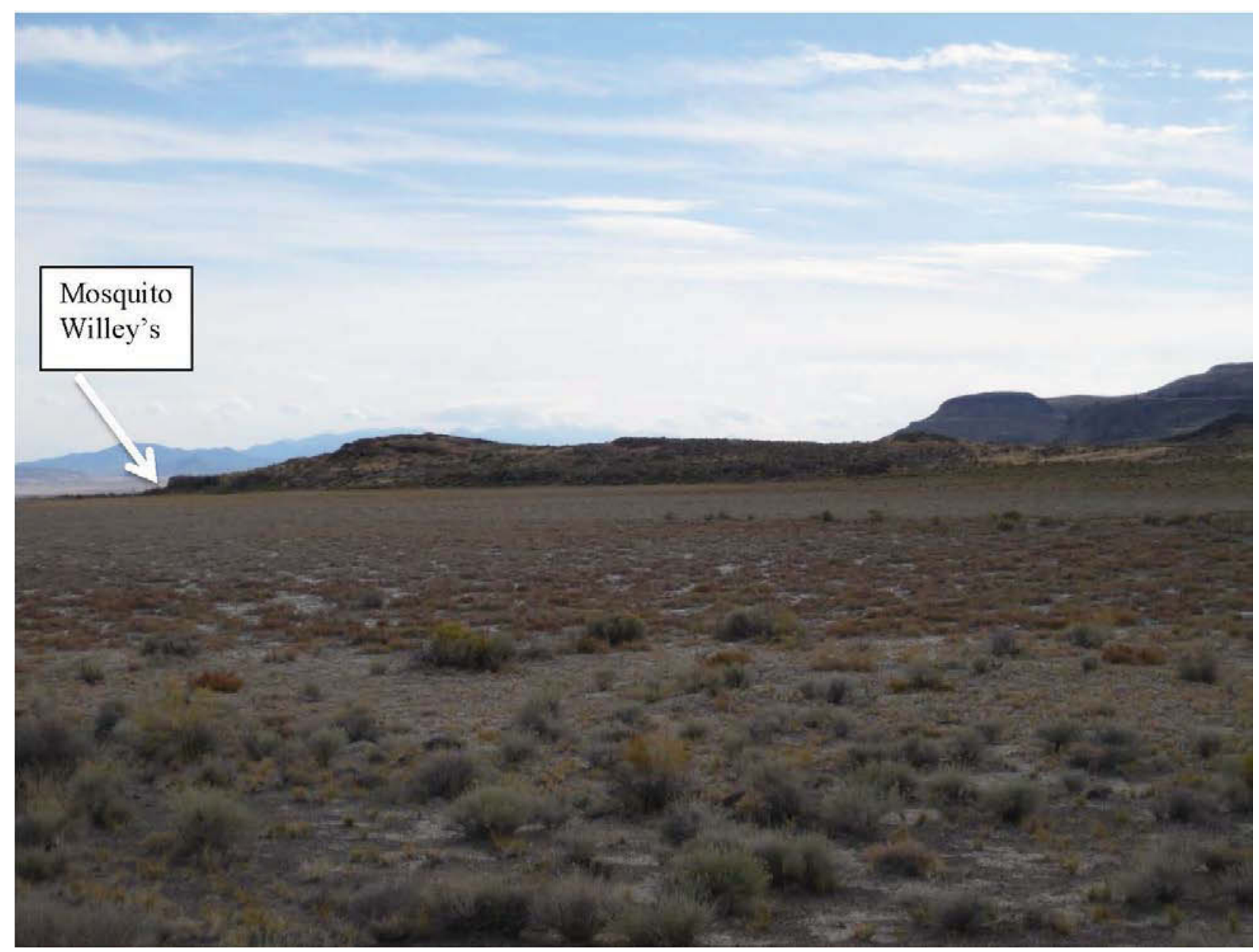

Figure C-9. Looking S-to-SW from the vicinity of lineament \#3 toward the NW-to-SE trending outcrop. The springs of Mosquiot Willy's emanate from the SE end of the outcrop. from the SE portion of which emanate the springs of Mosquito Willey's. Lineament \#4 runs roughly perpendicular to this outcrop. No offset was observed. 


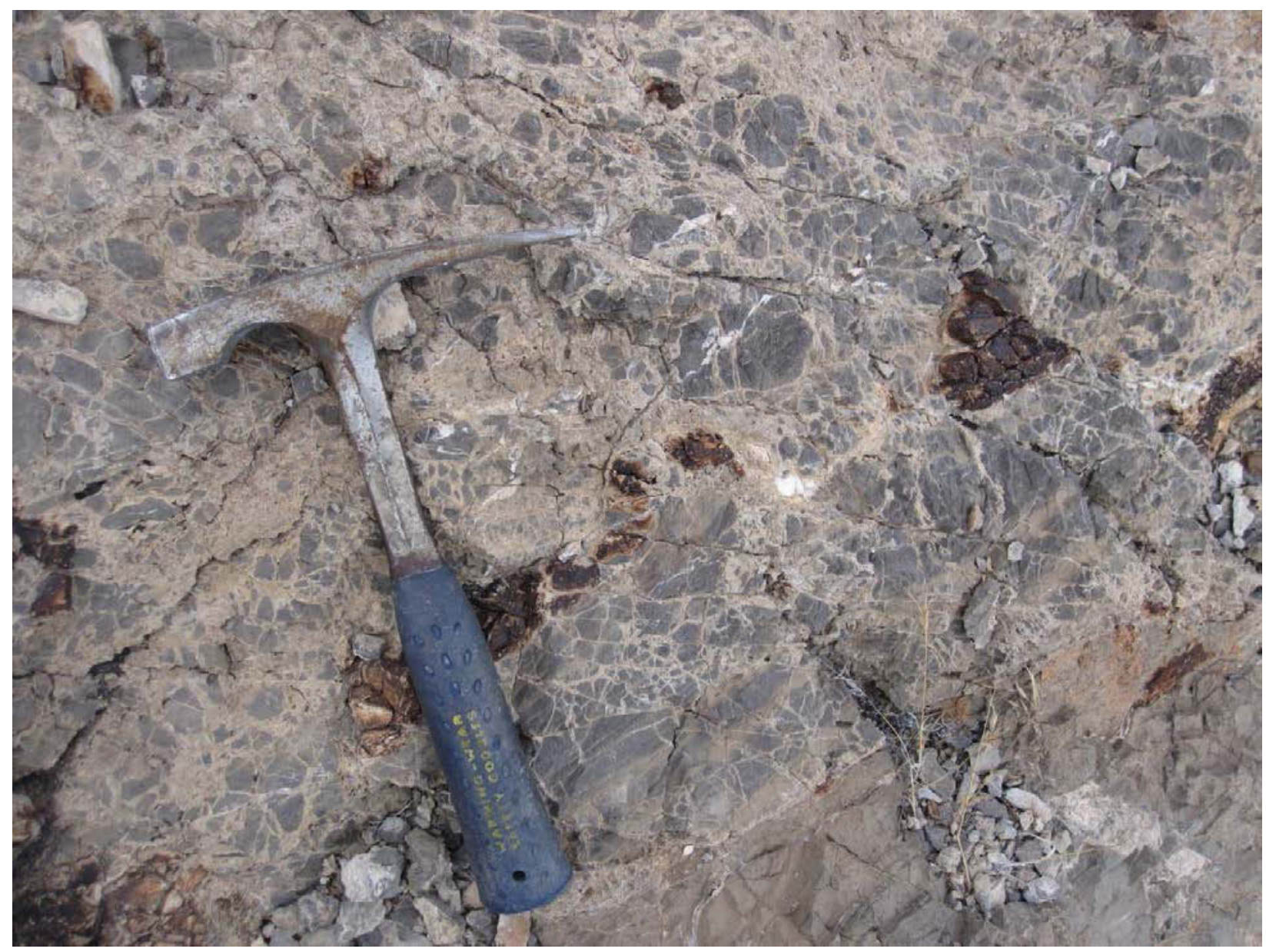

Figure C-10. Shear zone in a limestone outcrop in the vicinity of lineament \#6. 


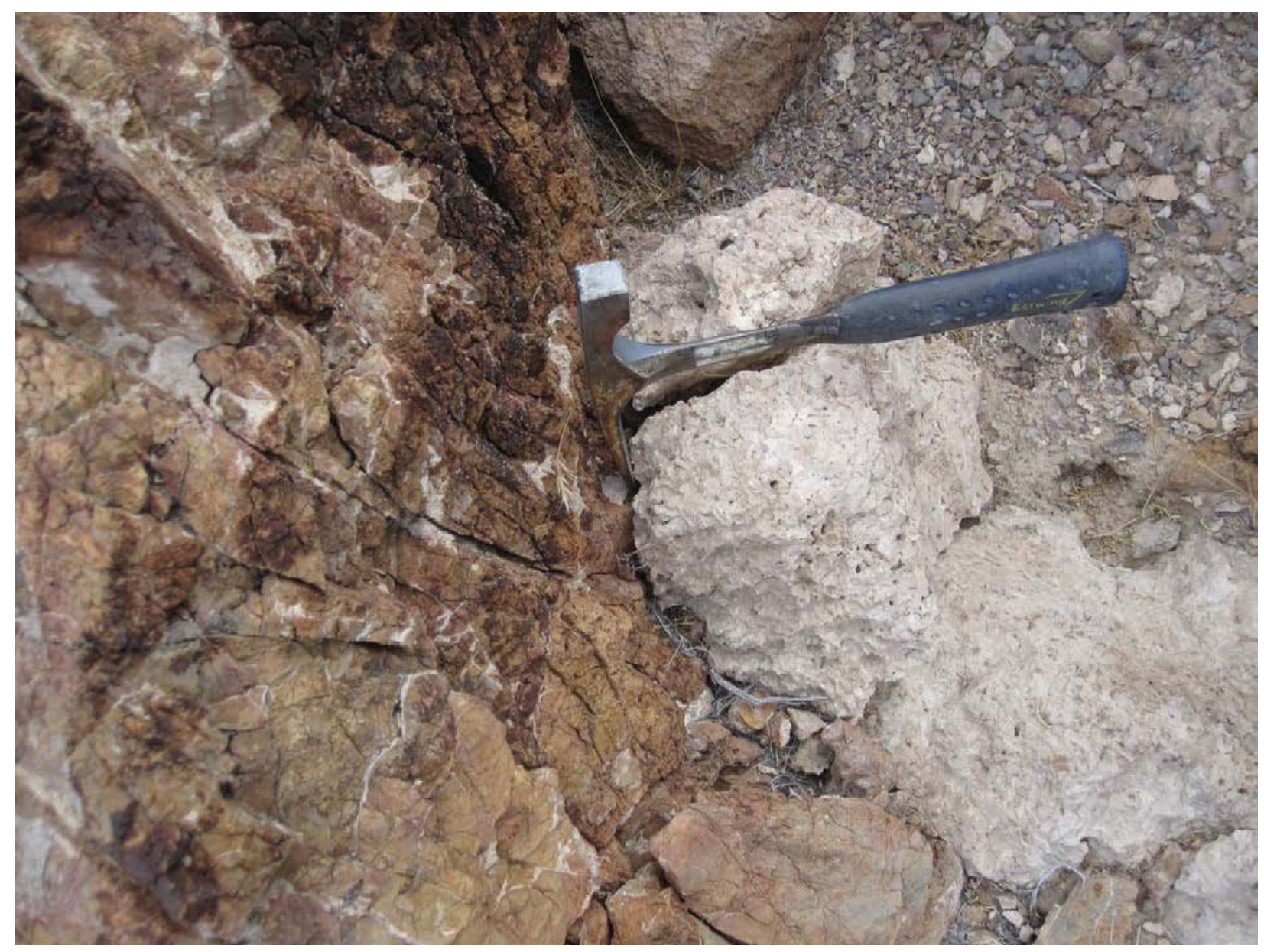

Figure C-11. White botryoidal calcite deposit at the base of a limestone outcrop in the vicinity of lineament \#6. The limestone contains dark brown chert nodules. 


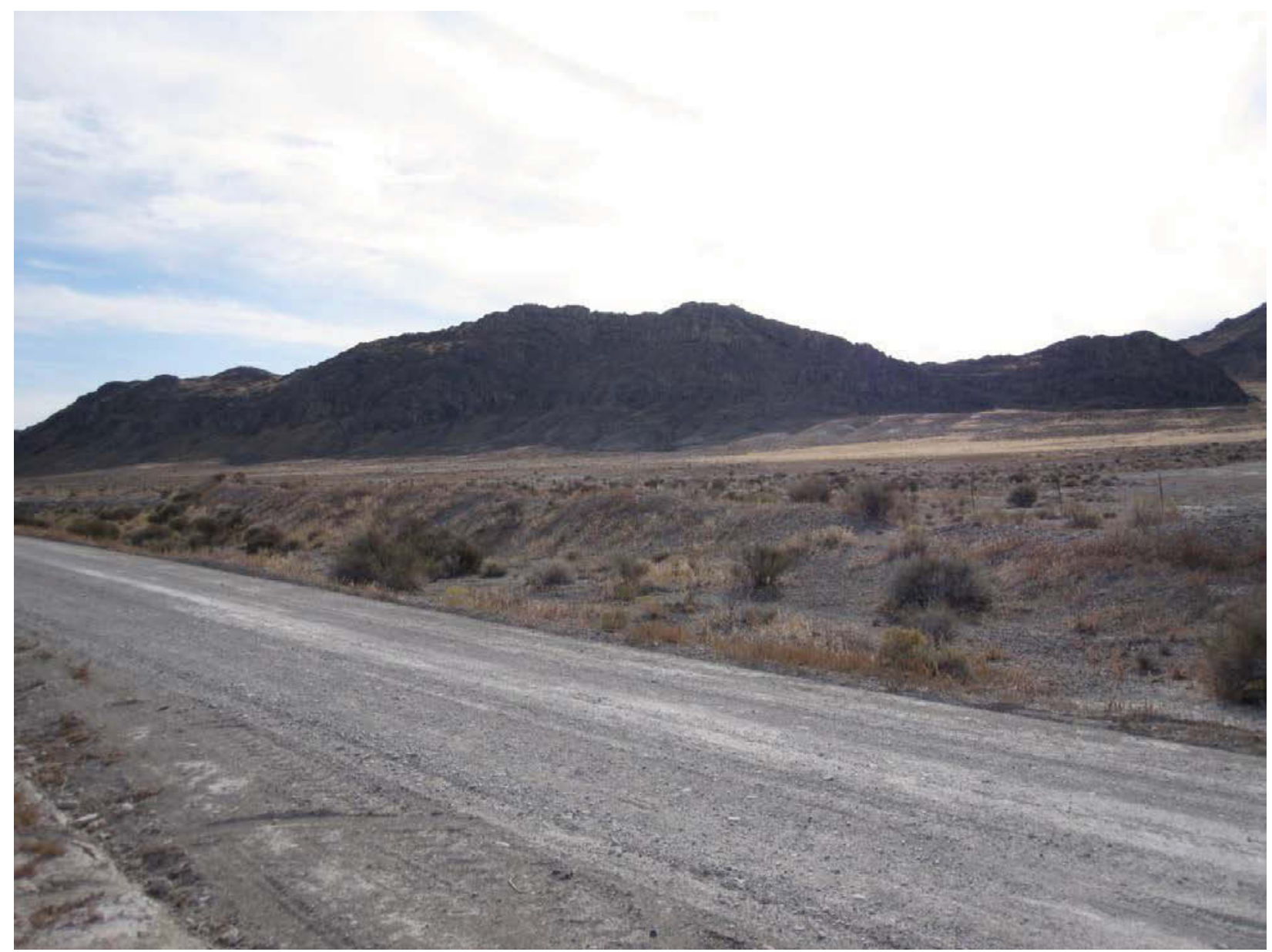

Figure C-12. Lineament \#6 follows the base of this NW-SE trending limestone fin. 


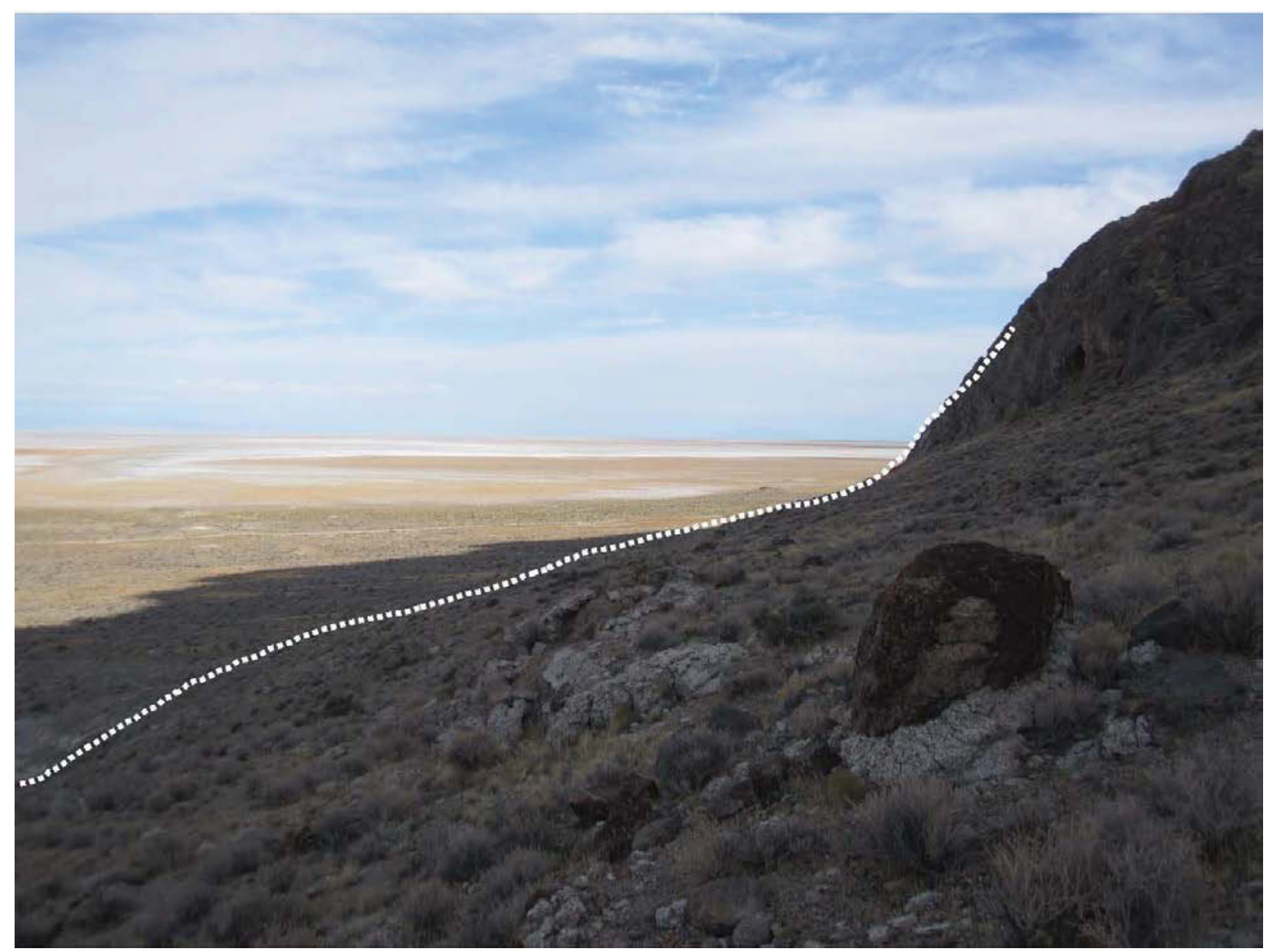

Figure C-13. Looking SE along lineament \#6 as it follows the base of this NW-SE trending limestone fin. Note the breaks in slope. 


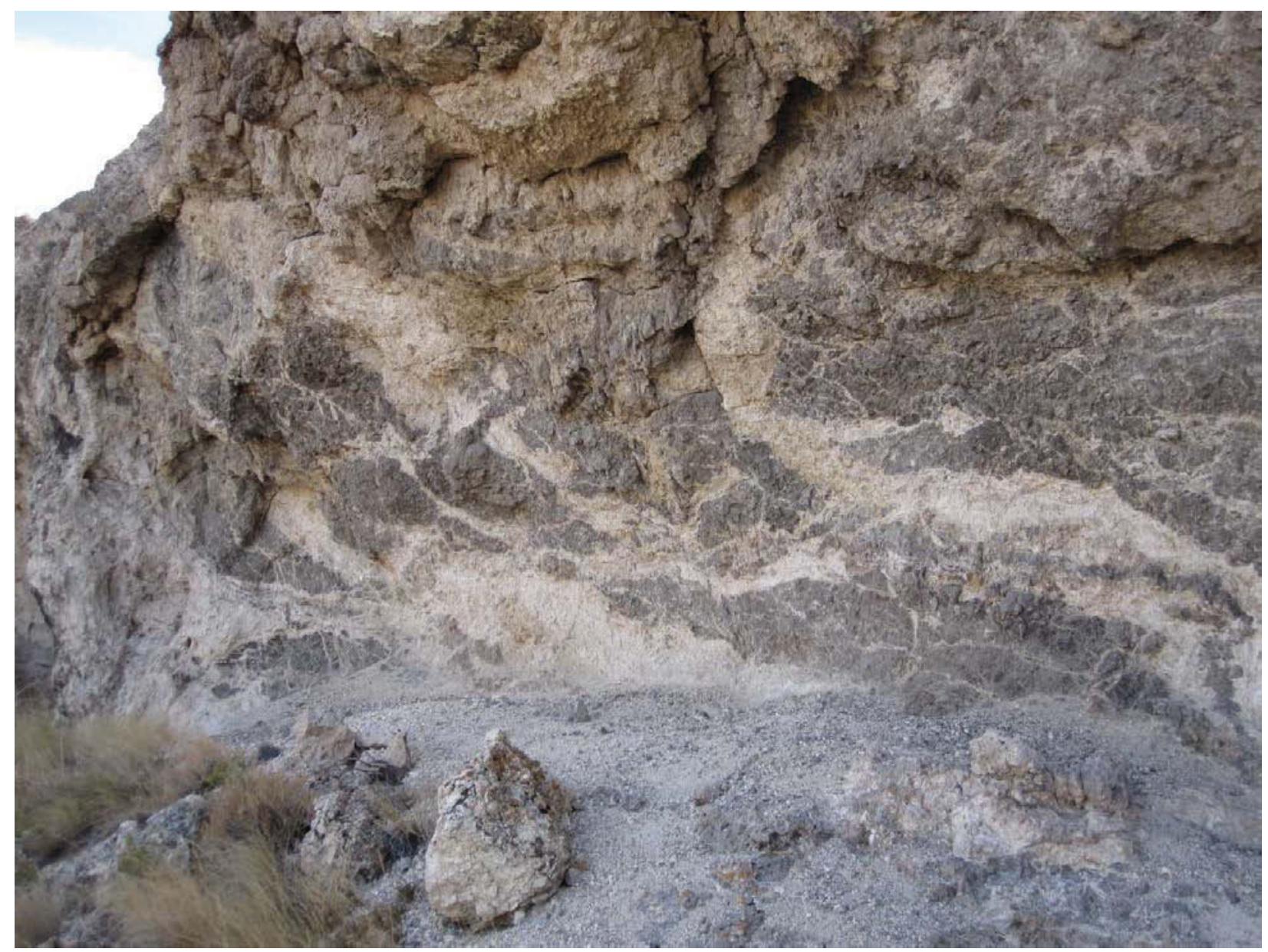

Figure C-14. Extensively brecciated limestone in the vicinity of lineament \#6. The outcrop is approximately $2 \mathrm{~m}$ in height. 


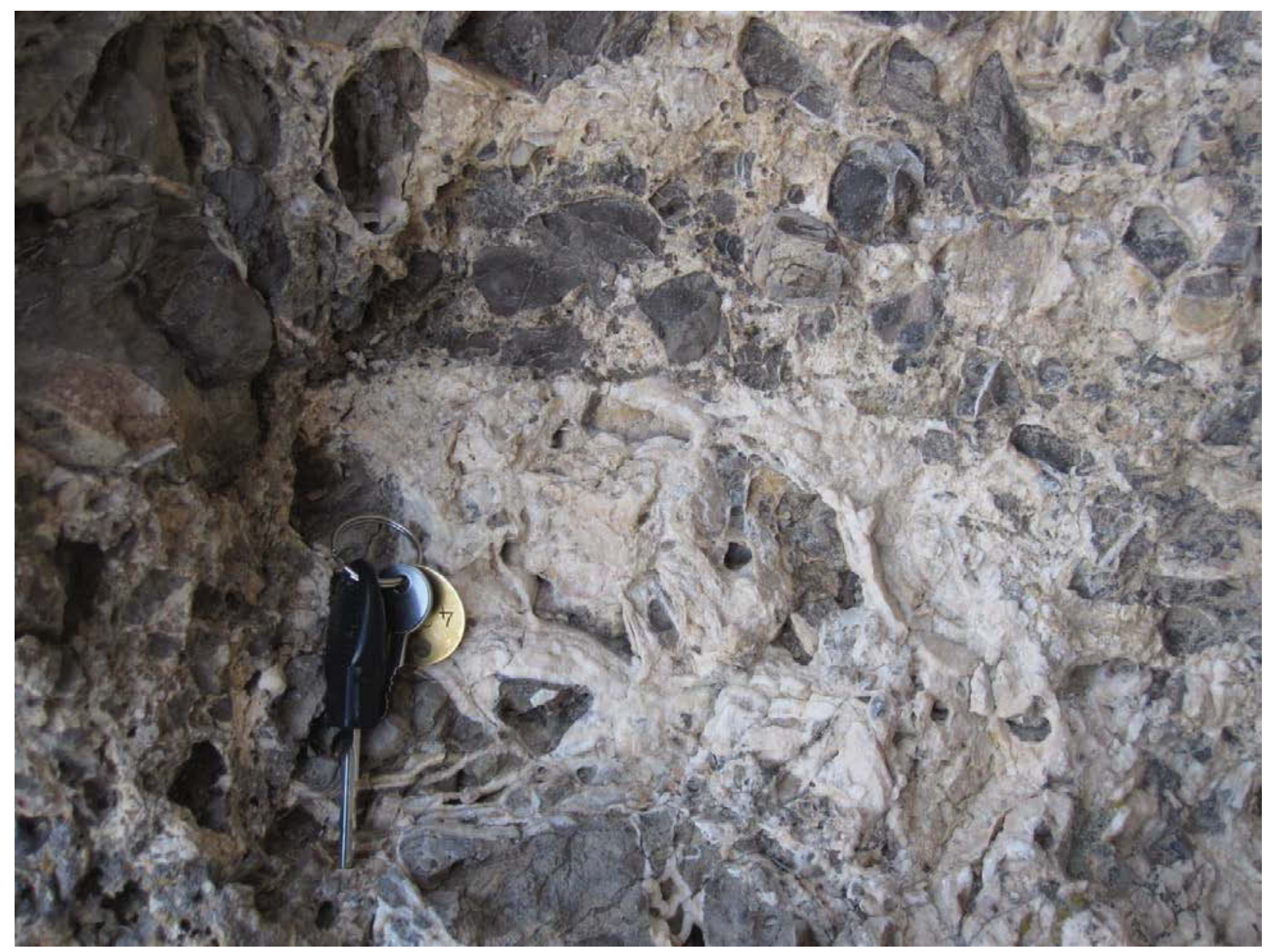

Figure C-15. Brecciated limestone cemented by calcite. 


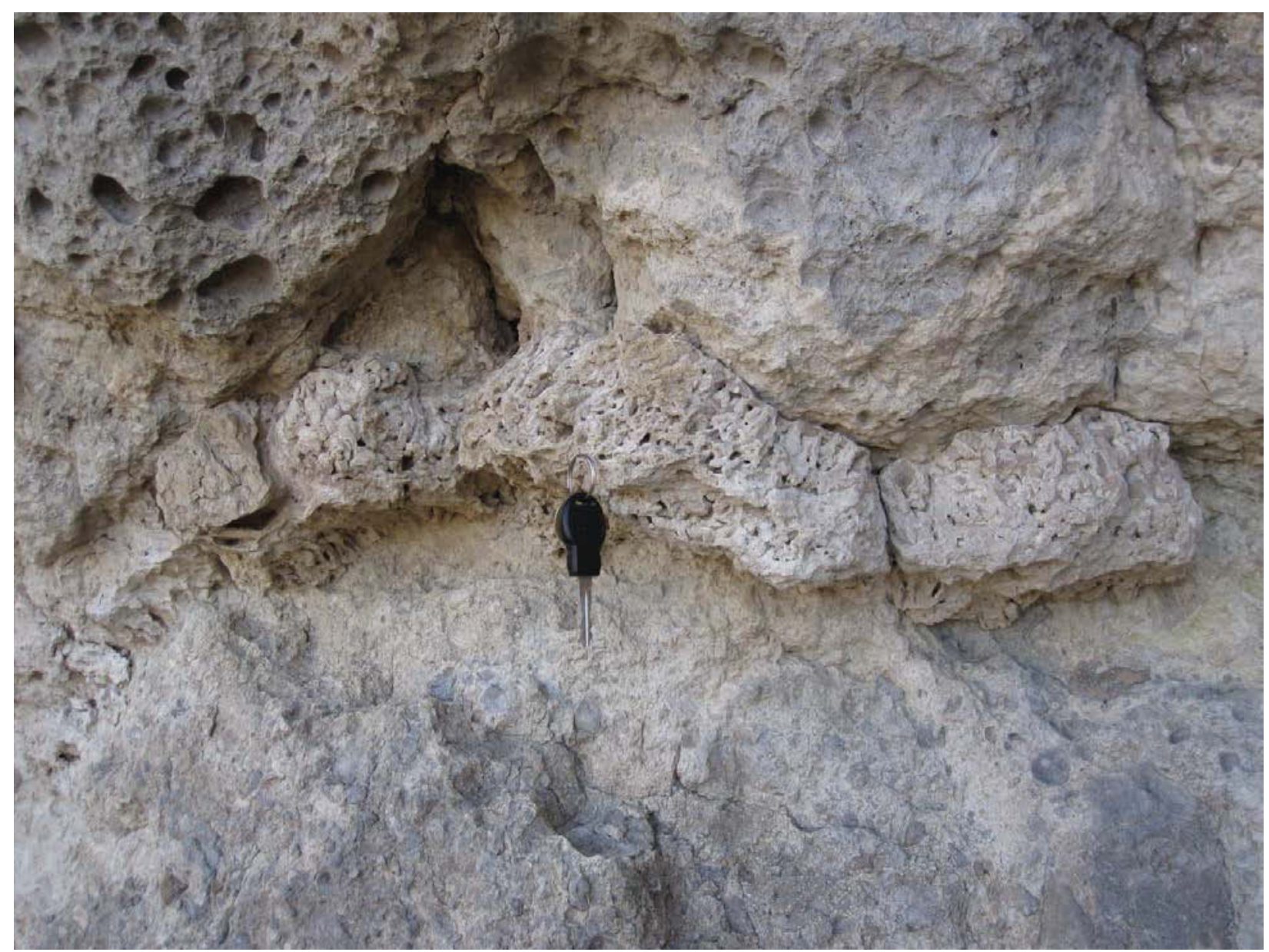

Figure C-16. Botryoidal calcite deposits filling a fracture in a limestone outcrop. 


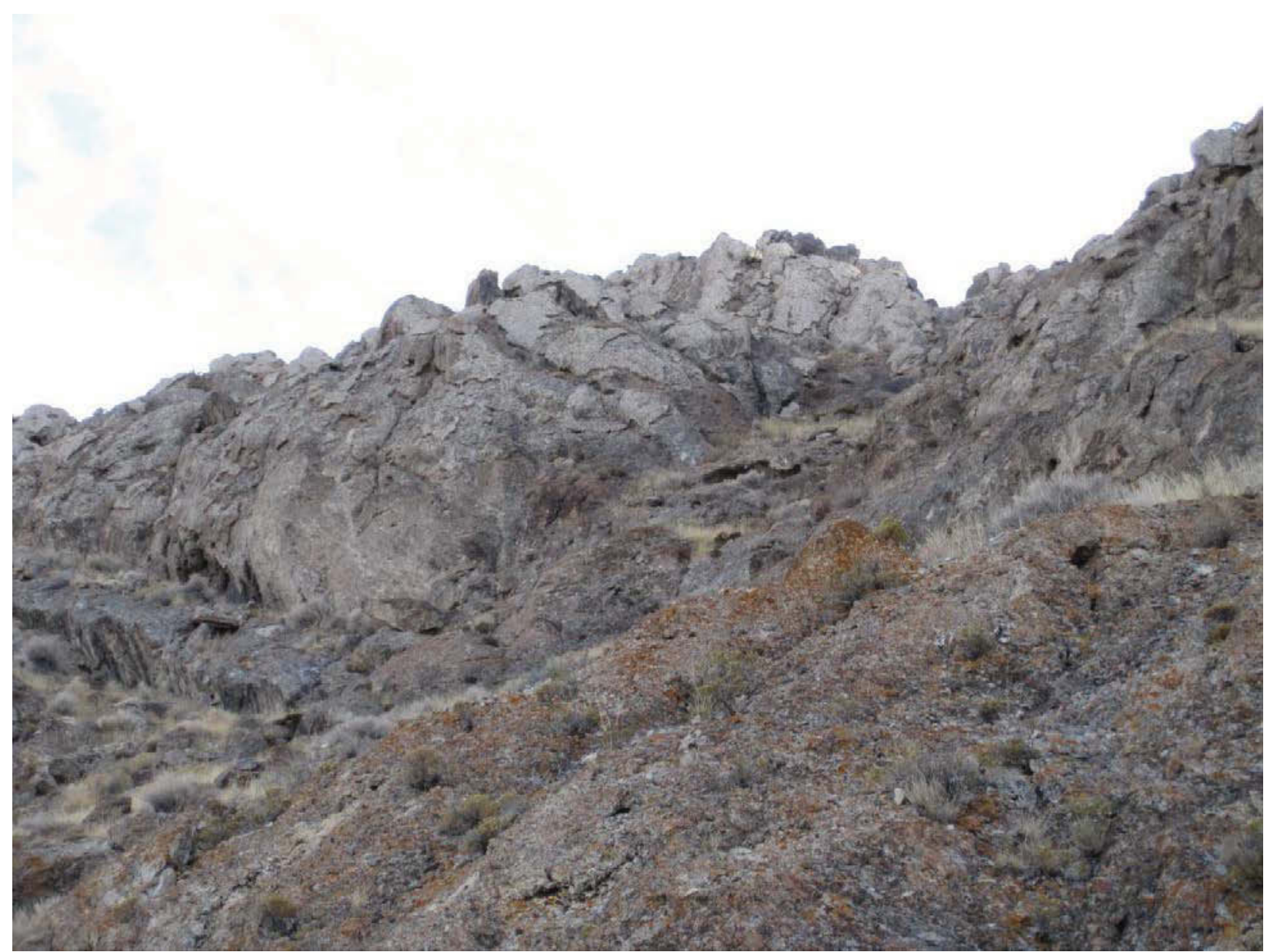

Figure C-17. Light colored botryoidal calcite deposits coating the entire height of the limestone fin. The outcrop is roughly $10 \mathrm{~m}$ tall. 


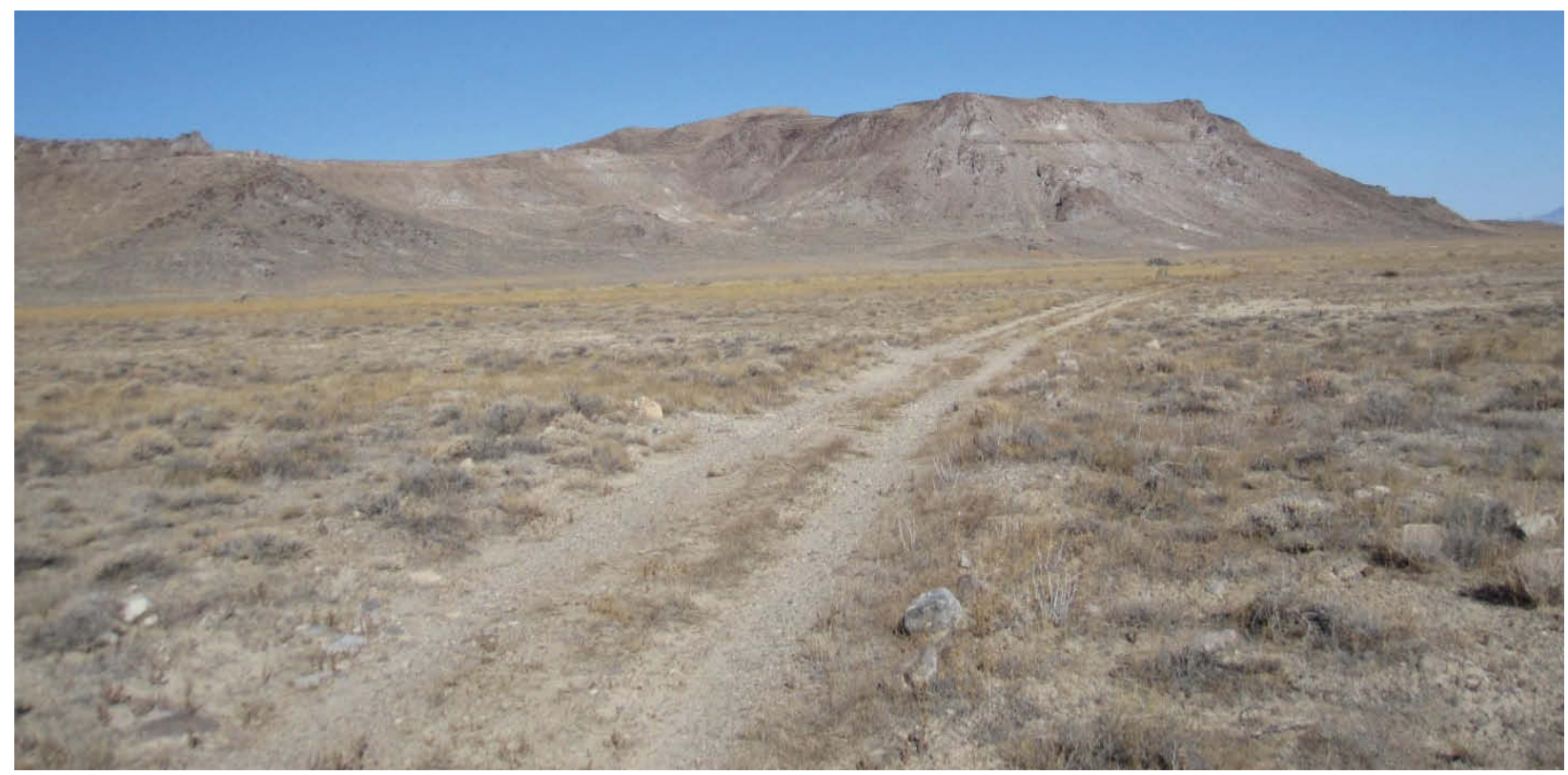

Figure C-18. Looking north toward a steep trapezoidal planar slope face that is roughly parallel to lineament \#7. Lineament \#7 crosses the picture between the spot the photo was taken and the distant slope. No topographic feature was observed.

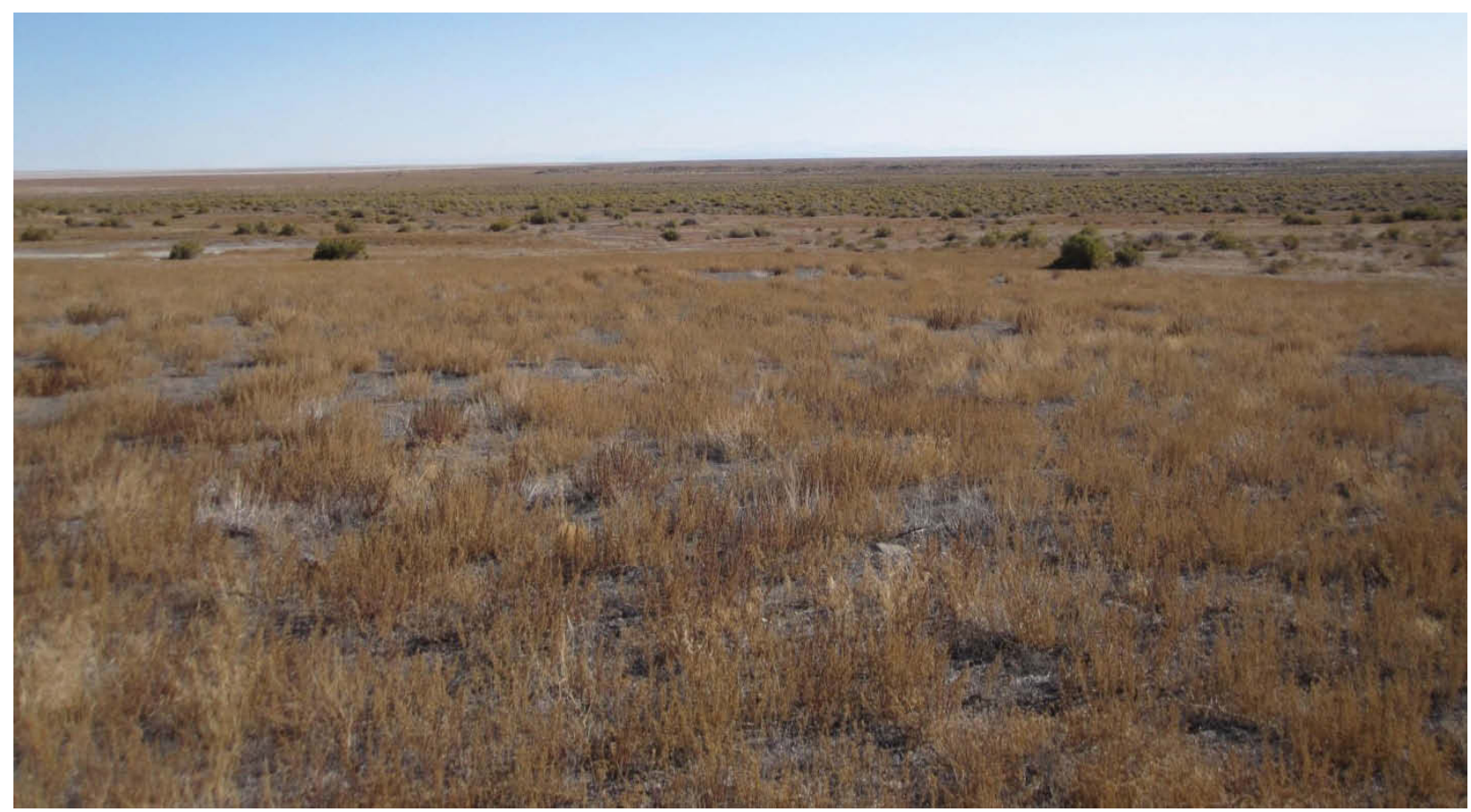

Figure $\mathrm{C}-19$. Change in vegetation that roughly parallels lineament \#7. Looking to the SE from near the bottom of the planar slope face shown at the far right of figure $\mathrm{C}-16$. 


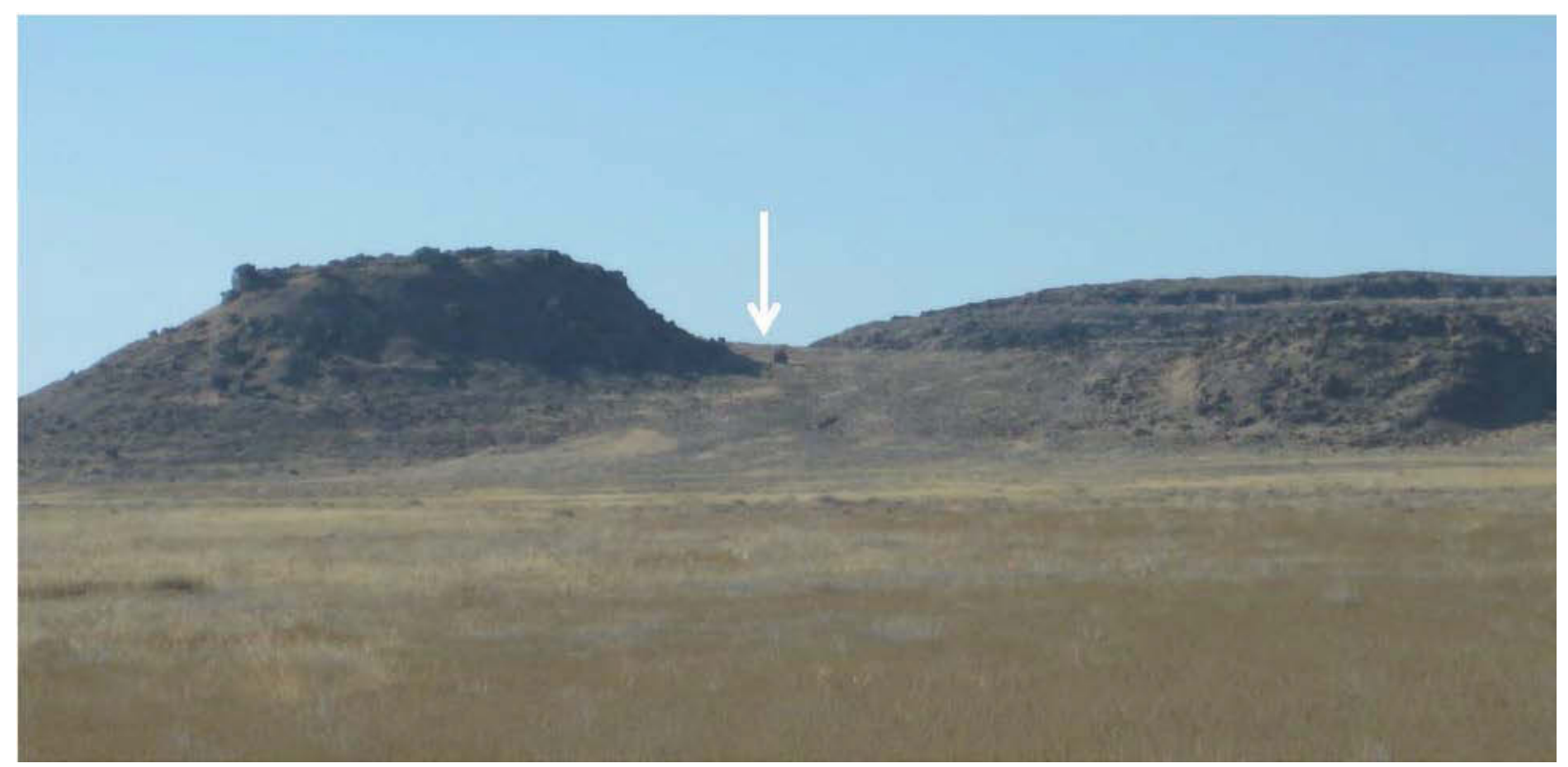

Figure C-20. Looking to the SW where lineament 8 crosses through the saddle (white arrow).

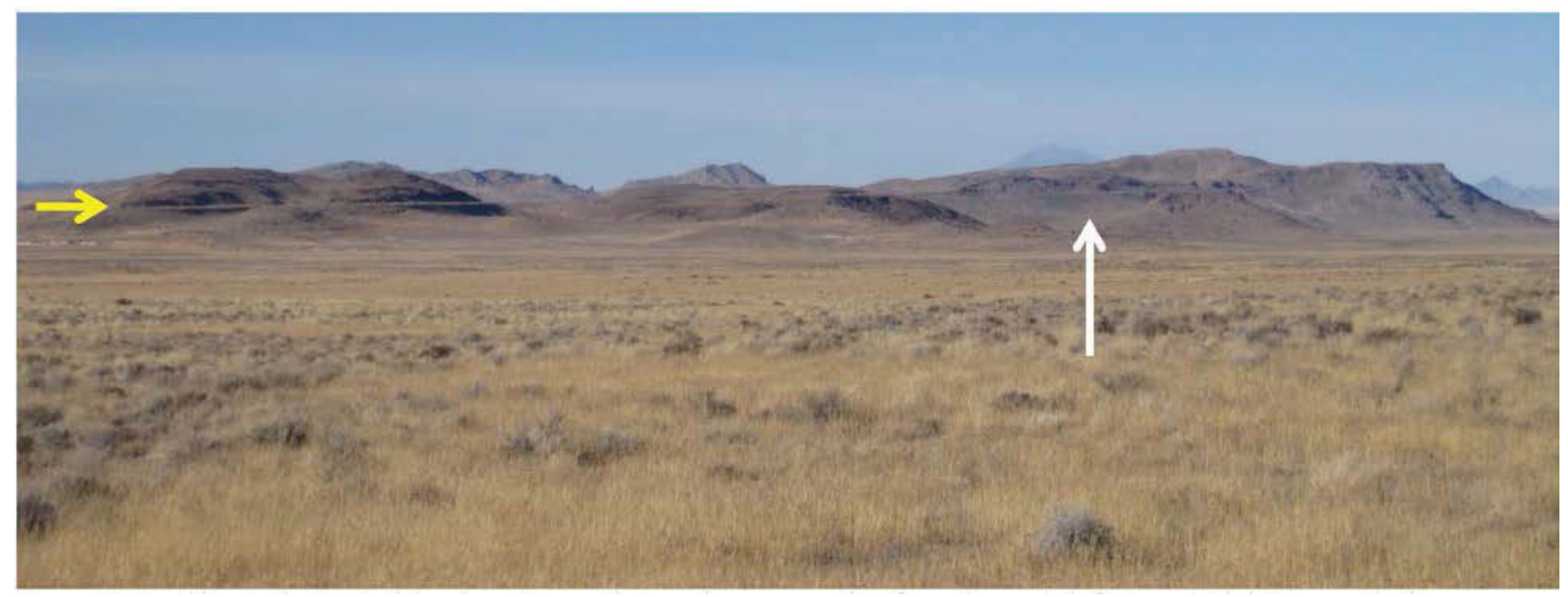

Figure C-21. Looking to the $\mathrm{N}$ at a lake shore terrace that can be seen running from the west (left) to east (right) across the image (yellow arrow). Lineament \#7 runs in from of the planar face shown in Figure C-16 (at the far right). Lineament \#8 cuts through the saddle shown by the white arrow. There is no offset between the lake terraces. 


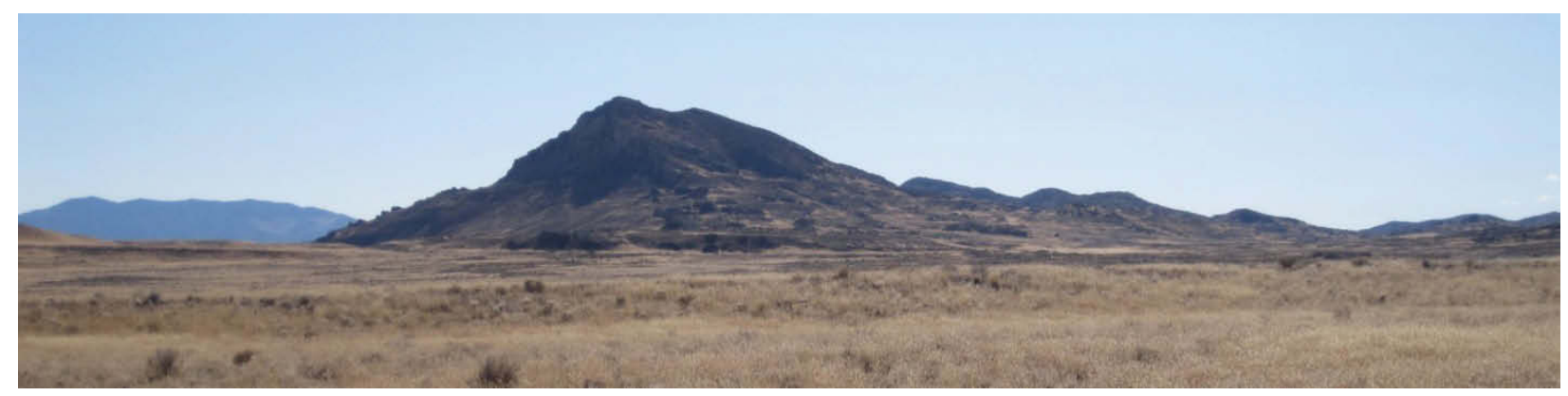

Figure C-22. Northern edge of 'Rocky Point' associated with lineament \#9. The lineament follows this feature around to the east (left).

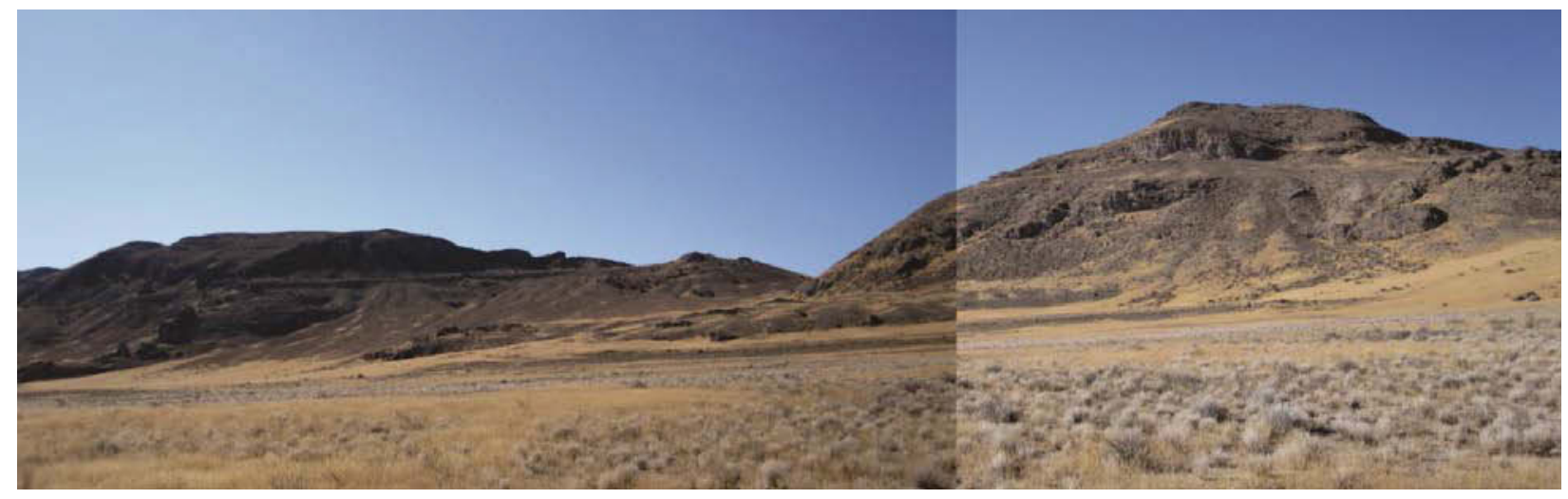

Figure C-23. Lineament \#10 cuts through the saddle perpendicular to lineament \#9 which runs along the base. A lake terrace can be correlated from one side to the other demonstrating that there hasn't been any offset since the lake level was last at this height. A thick band of limestone is also found just above the lake terrace on both sides of the saddle. 


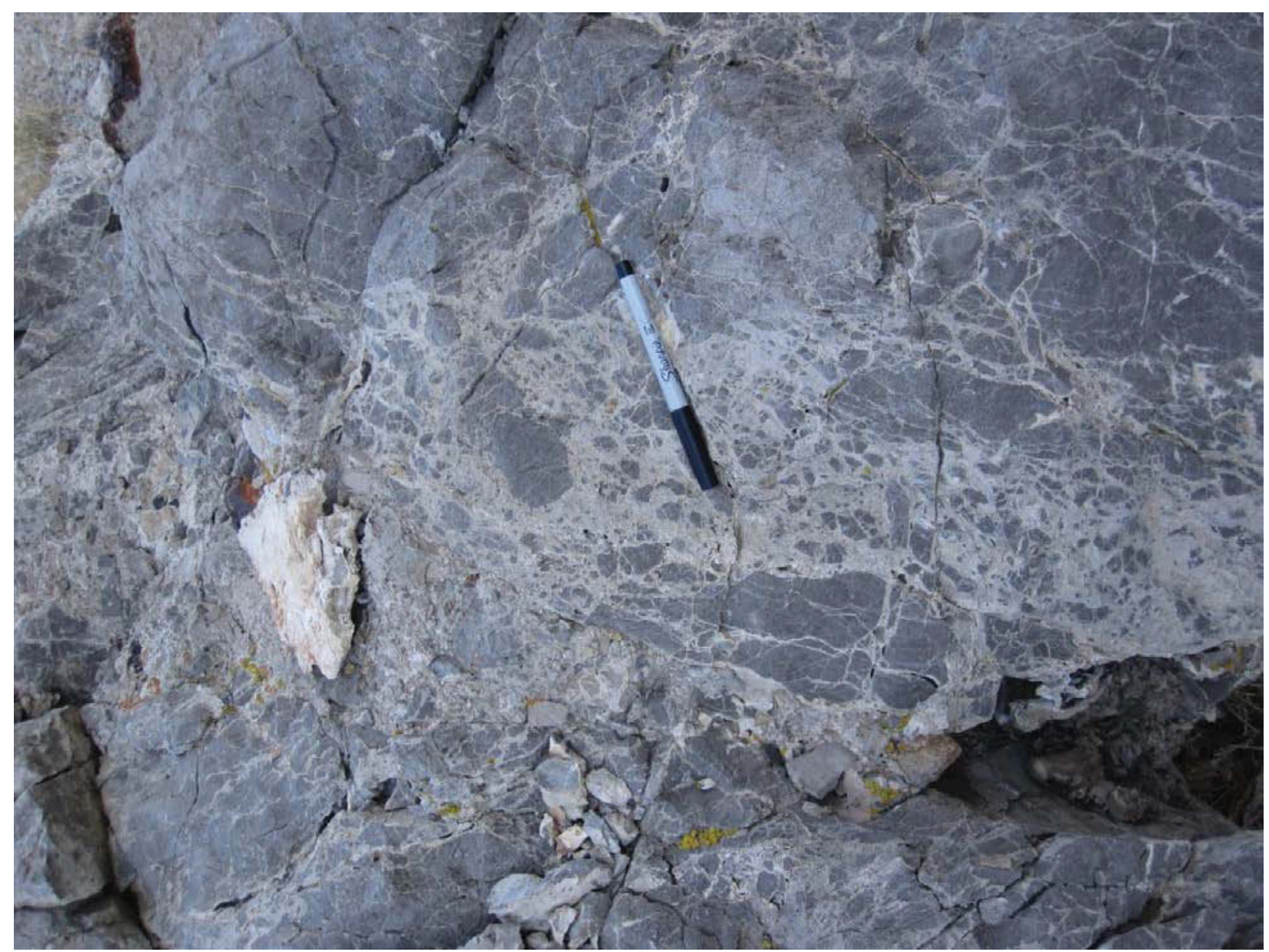

Figure C-24. Brecciated limestone cut by calcite veins, with a small piece of light colored botryoidal calcite on the exterior of this outcrop near lineament $\# 9$. 


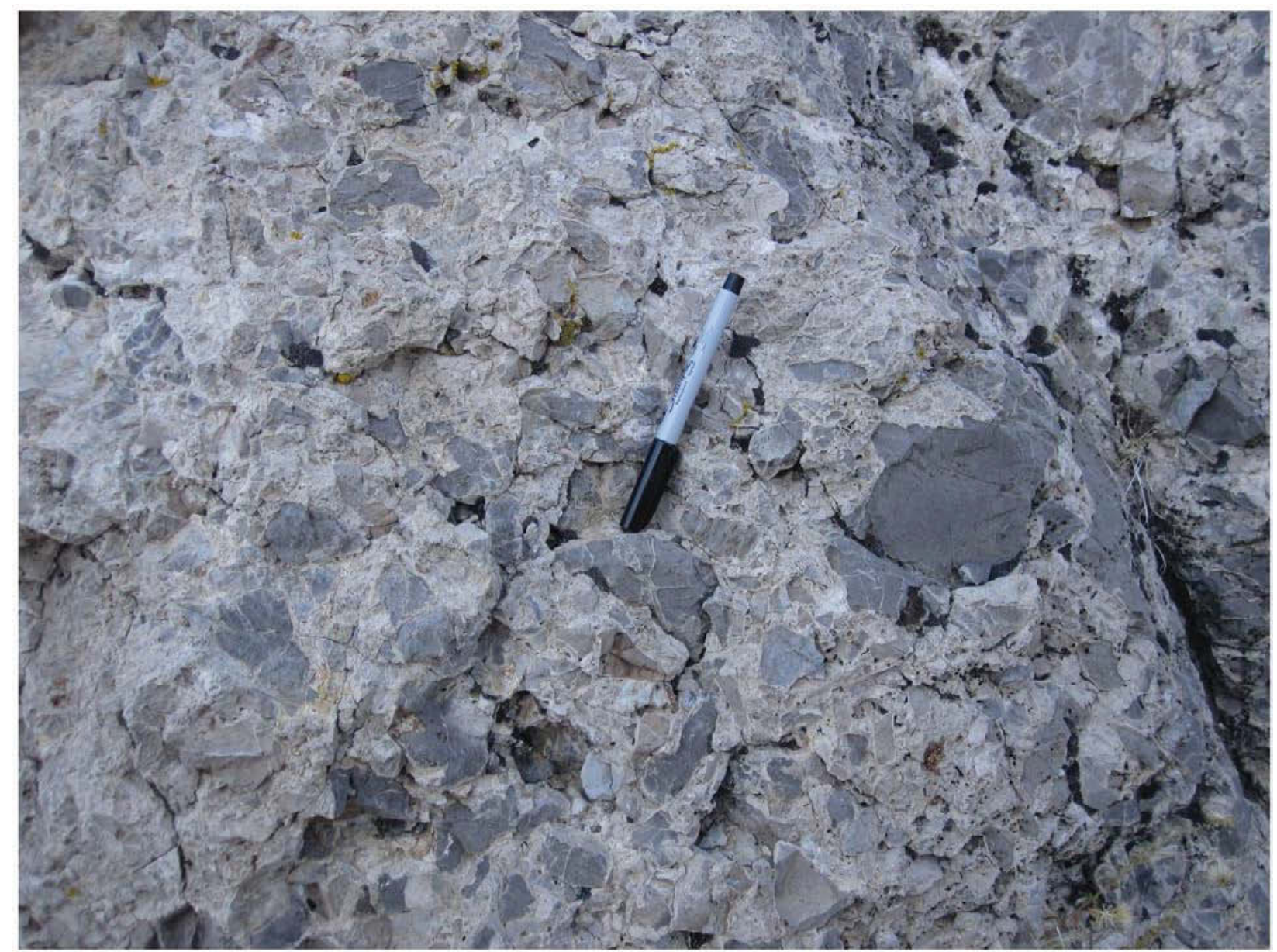

Figure C-25. Calcite-cemented conglomerate found in outcrop near lineament \#9.

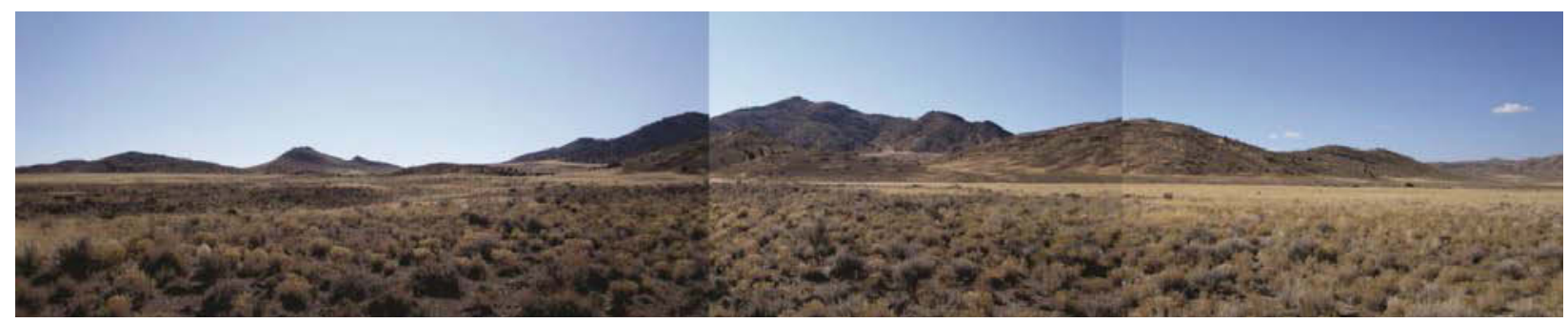

Figure C-26. Looking SW at where lineament \#14 was mapped crossing in front of the foothills running from the NW (right) to the SE (left). 


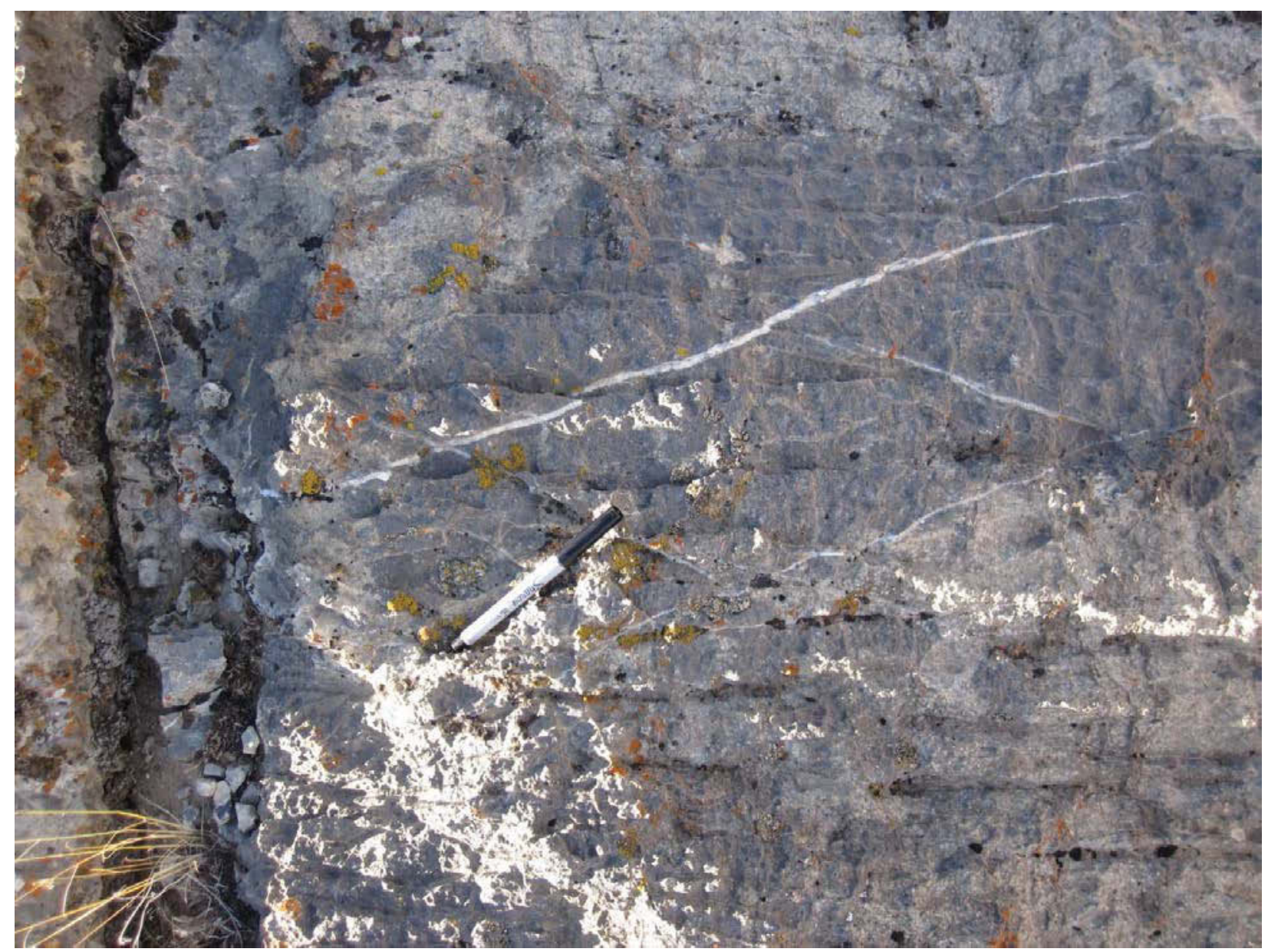

Figure C-27. Outcrop in the vicinity of lineament \#14, which showed little evidence of tectonism. 


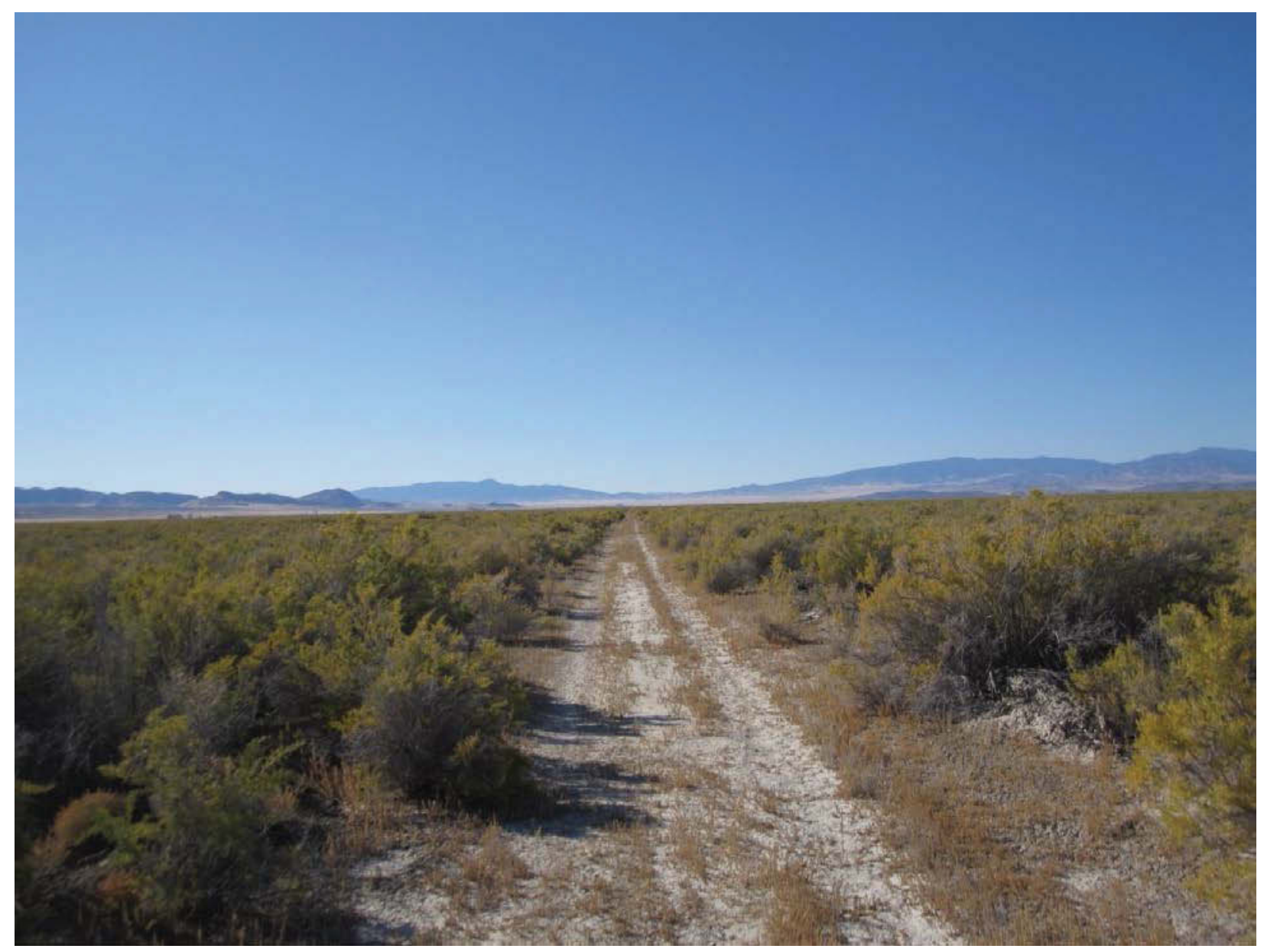

Figure C-28. Vicinity of lineament 12 which was flat and densely vegetated. 
This page intentionally left blank.

C-28 


\title{
Appendix D
}

\section{Analysis of Well Log Data from Wells Near Wendover, NV, for Estimation of Rock Properties}

\author{
Dan Brinton, John McLennan, and Joseph Moore \\ Energy and Geoscience Institute
}

\section{Introduction}

Borehole geophysical well logs, various descriptive logs (e.g., sample description logs, mud logs, core descriptions, and formation tops) and well files were obtained from the area near Focus Area 1. The data were used to estimate porosity, water saturation and matrix permeability of the subsurface. The results of the analyses indicate that porosity in the shallow Cenozoic rocks show average porosities between 16 and 35\%. Permeabilities in the Cenozoic rocks are typically greater than $100 \mathrm{mD}$, with the highest values exceeding $10 \mathrm{D}$. Calculated permeabilities greater than $1 \mathrm{D}$ are not considered reliable but suggest that permeabilities throughout the Cenozoic section are high. Porosity and permeability in the Paleozoic rocks vary with depth. In the Paleozoic section above $3500 \mathrm{ft}$, porosities range up to $15 \%$ with permeabilities ranging up to $70 \mathrm{mD}$. Below $3500 \mathrm{ft}$, porosities are typically less than $10 \%$ and permeabilities less than $10 \mathrm{mD}$.

\section{Data Acquisition and Selection}

Seven oil and gas wells were identified within approximately 30 miles of the center of Focus Area 1 and were evaluated as part of this study. Table D-1 lists the seven wells with their API numbers and common names. Figure D-1 shows the locations of the seven oil and gas wells in relation to Focus Area 1, which is outlined in red. Further information, including Township/Range/Section location description, latitude and longitude coordinates and logs available for the various wells are tabulated in Attachment D-1.

Table D-1. List of seven oil and gas wells within approximately 30 miles of Focus Area 1.

\begin{tabular}{|cclll|}
\hline API No. & State & \multicolumn{1}{c}{ County } & \multicolumn{1}{c|}{ Operator } & \multicolumn{1}{c|}{ Well Name } \\
\hline 27-007-05001 & Nevada & Elko & Western Osage Oil, Inc. & Government No. 1 \\
$27-007-05002$ & Nevada & Elko & Last Frontier Oil Co. & Government No. 1 \\
27-007-05012 & Nevada & Elko & Gulf Oil Corp. of California & Owl Hill Federal No. 1 \\
27-007-05207 & Nevada & Elko & Shell Oil Co. & Goshute Unit No. 1 \\
$27-033-05007$ & Nevada & White Pine & Gulf Refining Co. & Dennison-Federal No. 1 \\
$43-045-11076$ & Utah & Tooele & Swepi/Western Division & Salduro No. 1 \\
$43-045-30001$ & Utah & Tooele & Alpha Minerals & Alpha Govt. No. 1 \\
\hline
\end{tabular}


The GeoGraphix Discovery ${ }^{\mathrm{TM}}$ suite of programs was used for the management and interpretation of well log data. The GeoGraphix WellBase ${ }^{\mathrm{TM}}$ database was populated with the header information of the seven wells. Borehole geophysical logs were acquired from the Utah Division of Oil, Gas, and Mining (2011) and the Nevada Bureau of Mines and Geology (Hess, 2011) in TIF image format. The logs were then digitized using NeuraLog. The digitized logs were exported in log ASCII standard (LAS) format and imported into GeoGraphix PRIZM ${ }^{\mathrm{TM}}$, the well $\log$ analysis tool in the GeoGraphix Discovery ${ }^{\mathrm{TM}}$ suite. Mudlogs, sample descriptions, formation tops, etc. were also imported into GeoGraphix.

\section{Well Data Sets}

Well 43-045-30001 is located approximately 2.4 miles south of Interstate 80 and 14.7 miles east of the Utah/Nevada state line in section 34 of Township 1 south, Range 17 west, Salt Lake Base and Meridian. Ground elevation is $4222 \mathrm{ft}$. The well was drilled by Alpha Minerals, Inc. between December 23, 1975, and January 12, 1976, to a total depth of $4260 \mathrm{ft}$. Borehole geophysical logs were generated. Prints of these logs and a sample description log were obtained from the Utah Division of Oil, Gas, and Mining.

The well file indicates that the shallow portion of well 43-045-30001 penetrates lake sediments and alluvial conglomerate rocks believed to be of Quaternary age at its shallowest depths followed by Tertiary volcanic rocks at $500 \mathrm{ft}$ and Tertiary shale at $1128 \mathrm{ft}$. Based on the sample description and geophysical logs, the well appears to penetrate Paleozoic rocks near $3000 \mathrm{ft}$. The sample description log indicates a transition from mostly shale with some interbedded limestone in the shallow portion of the well to dolomite and limestone below $3000 \mathrm{ft}$. Additionally, the caliper log shows that the borehole is severely out of gauge between 1900 and $2750 \mathrm{ft}$; below $2800 \mathrm{ft}$, the caliper log shows only thin intervals where the borehole is out of gauge. Density and acoustic logs show a significant change from low density, high porosity rocks to high density, low porosity rocks at approximately $2970 \mathrm{ft}$. The well file contains documents that place the top of the Paleozoic rocks at either 2970 or $2980 \mathrm{ft}$. Bottom hole temperatures from the well log headers range from $148-153^{\circ} \mathrm{F}$.

Well 43-045-11076 is located approximately 7.0 miles west southwest of well 43-045-30001, 3.8 miles south of Interstate 80 and 7.8 miles east of the Utah/Nevada state line in section 4 of Township 2 south, Range 18 west, Salt Lake Base and Meridian. Ground elevation at the site is $4216 \mathrm{ft}$. The well was drilled by Shell Oil beginning on June 30, 1956, and reached a total depth of $2950 \mathrm{ft}$ on July 9, 1956. Borehole geophysical logs were run and the well was then plugged and abandoned on July 11, 1956. The well log headers list the bottom hole temperature to be $132^{\circ} \mathrm{F}$.

Wells 43-045-30001 and 43-045-11076 are on opposite sides of an interpreted normal fault, with well 43-045-11076 located on what would be the down-thrown side (Smith, 2011). An interval between 1450 and $1950 \mathrm{ft}$ depth in well 43-045-11076, characterized by elevated gamma ray $\log$ values appears to be correlative with an interval between 500 and $1150 \mathrm{ft}$ depth in well 43-045-30001, characterized by similarly elevated gamma ray log values. 
Wells 27-007-05001 and 27-007-05002 are located within approximately one-half mile of one another, about 13.6 miles south southwest of Wendover, NV, in sections 14 and 23, respectively, of Township 31 north, Range 69 east, Mt. Diablo Base and Meridian. The wells were drilled in the early to mid 1950s and information on their completions is scarce. The exact depth of well 27-007-05001 is not known but is thought to be about $785 \mathrm{ft}$, likely reaching to near the top of the Paleozoic rocks. Well 27-007-05002 was drilled to a total depth of $1327 \mathrm{ft}$ and is said to have intersected Permian rocks at $590 \mathrm{ft}$ followed by Pennsylvanian rocks at $1000 \mathrm{ft}$. A sample description log of this well is available; however no geophysical logs were run in either well.

Well 27-007-05012 was spudded on August 5, 1963, and is located approximately 30.4 miles south south-west of Wendover, Nevada in section 18, Township 28 north, Range 70 east, Mt. Diablo Base and Meridian. Ground elevation is approximately $5600 \mathrm{ft}$. Drilling was completed on August 31, 1963, after reaching a total depth of $1546 \mathrm{ft}$. A limited number of borehole logs were run to $1100 \mathrm{ft}$ and no sample description logs or formation tops are available. Well log headers indicate that the temperature at $1100 \mathrm{ft}$ depth is $86^{\circ} \mathrm{F}$. The caliper log shows that the borehole was frequently out of gauge below about $700 \mathrm{ft}$. The Nevada Oil and Gas Database indicates that the Mississippian Scotty Wash formation was penetrated at $562 \mathrm{ft}$.

Well 27-033-05007 is located about 43.4 miles south of Wendover, Nevada in section 20, Township 26 north, Range 70 east, Mt. Diablo Base and Meridian. Ground level at the site is $5504 \mathrm{ft}$. Drilling by Gulf Refining Company began on October 24, 1953, and concluded on March 1, 1954, after having reached a total depth of $4498 \mathrm{ft}$. Borehole geophysical logs were run and a formation top record is available covering the entire depth of the well. Bottom hole temperature from the well $\log$ headers is listed as $120^{\circ} \mathrm{F}$. According to the formation top record, the Permian Gerster-Phosphoria formation was penetrated at $2215 \mathrm{ft}$.

Well 27-007-05207 lies 22.2 miles to the west south-west of Wendover, Nevada in section 19, Township 32 north, Range 67 east, Mt. Diablo Base and Meridian. Ground elevation is approximately $5600 \mathrm{ft}$. Drilling commenced on January 30, 1976, and continued to a total depth of $5569 \mathrm{ft}$ before the well was abandoned on February 27, 1976. The well file contains a sample description log and a borehole log suite that is extensive in comparison with the other wells discussed. The Nevada Oil and Gas Well Database indicates that the well penetrated Permian rocks at $5280 \mathrm{ft}$. The well log headers indicate that the bottom hole temperature is $140^{\circ} \mathrm{F}$.

While well 27-007-05207 is somewhat closer to the center of Focus Area 1 than well 27-033-05007, it is located in Goshute Valley on the west side of the Toano Range (Focus Area 1 and other wells discussed are on the east side of the Toano Range). The geology of Goshute Valley is considered distinct from that of the area surrounding Focus Area 1 and the decision was therefore made to exclude well 27-007-05207 from further analysis and discussion.

Table D-2 contains the ground elevation, depth of the top of the Paleozoic rocks, well total depth and bottom hole temperatures for the seven wells just discussed. Bottom hole temperatures are affected by the drilling process as formation rock is cooled by circulating drilling fluid. These temperatures can be corrected for the affects of cooling during the drilling process but no such corrections were attempted in the present study. 
Table D-2. Ground elevations, tops of the Paleozoic rocks, total depth and bottom hole temperatures recorded in oil and gas wells near Focus Area 1.

\begin{tabular}{|lllll|}
\hline Well & \multicolumn{1}{c}{$\begin{array}{c}\text { Ground } \\
\text { Elevation (ft) }\end{array}$} & \multicolumn{1}{c}{$\begin{array}{c}\text { Top of } \\
\text { Paleozoic (ft) }\end{array}$} & $\begin{array}{c}\text { Total Depth } \\
(\mathbf{f t})\end{array}$ & \multicolumn{1}{c|}{$\begin{array}{c}\text { Bottom Hole } \\
\text { Temperature }\left({ }^{\circ} \mathbf{F}\right)\end{array}$} \\
\hline $27-007-05001$ & $?$ & $?$ & 785 & $?$ \\
$27-007-05002$ & $?$ & 590 (Permian) & 1327 & $?$ \\
$27-007-05012$ & 5600 & 562 (Mississippian) & 1546 & $86(@ 1100 \mathrm{ft})$ \\
$27-007-05207$ & 5600 & 5280 (Permian) & 5569 & $140($ @ 5434 ft) \\
$27-033-05007$ & 5504 & 2215 (Permian) & 4498 & 120 \\
$43-045-11076$ & 4216 & N/A & 2950 & 132 \\
$43-045-30001$ & 4222 & 2970 & 4260 & $148-153$ \\
\hline
\end{tabular}

\section{Analysis of Well 43-045-30001}

\section{Methodology}

Well logs from well 43-045-30001 were analyzed to estimate the porosity, water saturation and permeability of potential reservoir rocks in the area surrounding Focus Area 1.

\section{Porosity}

Matrix density and sonic wave travel time values were selected for individual intervals based on the lithologies identified in the sample description log of well 43-045-30001. Porosities (density porosity and sonic porosity) of the well were calculated according to the porosity equations given in Table D-3. In the Cenozoic section, non-carbonate rocks were assigned the matrix density of sandstone. The only exceptions were intervals characterized as volcanic rocks and shales. All rock intervals described as volcanic were assigned a matrix density between that of andesite and basalt. In intervals characterized in the sample description log as shales, rock matrix properties of intervals immediately above were used in the porosity equations. Porosity equation rock matrix parameters (matrix density, $\rho_{m a}$, and acoustic wave travel time, $\Delta t_{m a}$ ) are listed in Table D-4.

Table D-3. Porosity equations used in estimating sonic and density porosity (Asquith, 1983).

\begin{tabular}{|ccc|}
\hline $\begin{array}{c}\text { Porosity } \\
\text { Type }\end{array}$ & Equation & Eq. No. \\
\hline Density & $\phi_{\mathrm{D}}=\frac{\left(\rho_{\mathrm{ma}}-\rho_{\mathrm{B}}\right)}{\left(\rho_{\mathrm{ma}}-\rho_{\mathrm{fld}}\right)}$ \\
Sonic & $\phi_{\mathrm{S}}=\frac{\left(\Delta \mathrm{t}-\Delta \mathrm{t}_{\mathrm{ma}}\right)}{\left(\Delta \mathrm{t}_{\mathrm{fld}}-\Delta \mathrm{t}_{\mathrm{ma}}\right)}$ \\
\hline $\begin{array}{l}\text { - Fluid properties: } \rho_{\mathrm{fld}}=1.00 \mathrm{~g} / \mathrm{cc} ; \Delta \mathrm{t}_{\mathrm{fld}}=189 \mu \mathrm{s} / \mathrm{ft} \\
\text { - } \rho_{\mathrm{B}} \text { is the bulk density read from the density log. } \\
\text { - } \Delta \mathrm{t} \text { is the acoustic wave travel time read from the acoustic log. }\end{array}$ \\
\hline
\end{tabular}


Table D-4. Rock matrix parameters used in porosity equations.

\begin{tabular}{|c|c|c|c|}
\hline Age & Lithology & $\begin{array}{c}\text { Density, pma } \\
\text { (g/cc) }\end{array}$ & $\begin{array}{c}\text { Acoustic Wave } \\
\text { Travel Time, } \\
\Delta \text { tma }(\mu \mathrm{s} / \mathrm{ft})\end{array}$ \\
\hline \multirow{9}{*}{ Cenozoic } & Conglomerate & 2.65 & \\
\hline & Claystone & 2.65 & \\
\hline & Chert & 2.65 & \\
\hline & Dolomite & 2.876 & 43.5 \\
\hline & Limestone & 2.71 & 47.6 \\
\hline & Mudstone & 2.65 & \\
\hline & Sandstone & 2.65 & 53.5 \\
\hline & Siltstone & 2.65 & \\
\hline & Volcanic & 2.8 & \\
\hline \multirow{4}{*}{ Paleozoic } & Dolomite & 2.876 & 43.5 \\
\hline & Gypsum & 2.317 & 52.4 \\
\hline & Limestone & 2.793 & 47.6 \\
\hline & Sandstone & 2.65 & 53.5 \\
\hline
\end{tabular}

\section{Shale Volume}

The presence of shale can result in the sonic and density logs predicting porosities that are artificially high. Modified porosity equations that account for the shale volume can be used to give more realistic estimations of porosity if the shale volume is known.

Shale volume is typically estimated from: (1) the gamma ray log; (2) the spontaneous potential (SP) log; and (3) the neutron-density porosity log. It is common for shale volume to be estimated using each of the three methods and the minimum of the three taken as the actual shale volume for any given depth (Hilchie, 1982). No neutron log was available for well 43-045-30001; thus the shale volume was calculated from the gamma ray and SP logs.

In order to calculate the shale volume based on the gamma ray log, the gamma ray index (IGR) is first calculated. The IGR (see Equation 3 ) is the gamma ray value normalized by the difference between the gamma ray values of shale and clean intervals (Schlumberger, 1974):

$$
\mathrm{I}_{\mathrm{GR}}=\frac{\mathrm{GR}_{\mathrm{log}}-\mathrm{GR}_{\text {min }}}{\mathrm{GR}_{\text {max }}-\mathrm{GR}_{\text {min }}}
$$

where GRmax is the gamma ray value in a shale bed and GRmin is the gamma ray value in a shale-free interval and GRlog is the reported gamma ray value at a particular depth. GRmax was taken as the average gamma ray value in the interval from 3144 to $3146 \mathrm{ft}$; GRmin was taken as the average in the interval from 3852-3864 ft.

The gamma ray index can itself be taken as the shale volume; however, Equation 4 (Dresser Atlas, 1979) provides improved accuracy by accounting for rock age and consolidation.

$$
\begin{aligned}
& \qquad \mathrm{V}_{\mathrm{shl}, \mathrm{GR}}=\mathrm{C}_{1}\left[2^{\left(\mathrm{C}_{2} \cdot \mathrm{I}_{\mathrm{GR}}\right)}-1.0\right] \\
& \mathrm{C} 1=0.33 ; \mathrm{C} 2=2 \text { for older, consolidated rocks } \\
& \mathrm{C} 1=0.083 ; \mathrm{C} 2=3.7 \text { for Tertiary, unconsolidated rocks }
\end{aligned}
$$


The shale volume from the SP is calculated according to Equation 5 (Asquith, 1983):

$$
\mathrm{V}_{\mathrm{shl}, \mathrm{SP}}=1.0-\frac{\mathrm{PSP}}{\mathrm{SSP}}
$$

The static spontaneous potential (SSP) is the SP value read from the SP log in a thick, shalefree formation and represents the largest divergence of the SP log curve from the shale baseline. The pseudostatic spontaneous potential (PSP) is the SP of a shaly formation. For the current calculations, SSP was identified as the average SP value from 3862-3866 ft. That SSP value was used in shale volume calculations throughout the well.

SP curves tend to drift due to calibration problems or borehole conditions. Therefore, before the shale volume was calculated based on the SP curve, a baseline correction was performed in GeoGraphix PRIZMTM utilizing a tool specifically designed for that purpose. Figure D-2 is a screen shot from PRIZMTM showing the original SP curve in blue and the new baseline imposed on the data in red. The new baseline (the so-called shale baseline) is the zero point for the SP curve and all SP values are read relative to it.

SP logs are also affected by thin beds. Corrections can be applied to account for thin bed effects, but no such corrections were applied in the present analysis. After the baseline correction operation was performed, SSP was identified and the volume of shale was calculated from the SP $\log$ as described in Equation 5.

In some intervals, the gamma ray and SP logs predict widely different shale volumes. Additionally, the character of the two curves sometimes oppose one another; the gamma ray shows an increase in shale volume while the SP shows a decrease in shale volume in a particular interval, for example. This is especially true in the shallow portions of the well. The agreement between methods is much better in the deeper portions of the well.

When the shale volume calculated using either method was greater than $100 \%$, the maximum value of $100 \%$ was imposed. Similarly, when the calculated shale volume was less than $0 \%$, the minimum value of $0 \%$ was imposed. In this study, the shale volume at any given depth in the well was taken as the lesser of the gamma ray- and SP-derived shale volumes. The only exception is intervals of volcanic rock. The behavior of SP and gamma ray logs is not well documented in igneous rocks. As such, shale volume was not calculated and, for the sake of further calculations, is assumed to be zero in volcanic rock intervals.

\section{Shale Volume-Corrected Porosity}

Density and sonic porosities were corrected for the shale volume according to the equations given in Table D-5 (Dresser Atlas, 1979). Hilchie suggests that shale only begins to affect log values when the shale content is greater than 10-15\% (Hilchie, 1982). Accordingly, the corrections were applied only where the shale volume is estimated to be greater than $10 \%$. Shale properties (density and acoustic wave travel time) used in Equations 6 and 7 and listed in Table D-5 were taken as the average density log value and the average acoustic wave travel time value recorded between 1135 and $1140 \mathrm{ft}$ for the Cenozoic section and between 3143 and $3145 \mathrm{ft}$ for the Paleozoic section. These properties were used in various calculations throughout the depth of the well. 
Table D-5. Equations and parameter values used in calculating sonic and density porosity corrected for shale effects.

\begin{tabular}{|l|l|}
\hline Porosity Type & Equation \\
\hline $\begin{array}{l}\text { Density } \\
\text { corrected for } \\
\text { shale volume) } \\
\text { Sonic } \\
\text { (corrected for } \\
\text { shale volume) }\end{array} \quad \square_{\mathrm{D}, \text { corr }}=\frac{\rho_{\mathrm{ma}}-\rho_{\mathrm{B}}}{\rho_{\mathrm{ma}}-\rho_{\mathrm{fld}}}-\mathrm{V}_{\mathrm{shl}} \cdot\left(\frac{\rho_{\mathrm{ma}}-\rho_{\mathrm{shl}}}{\rho_{\mathrm{ma}}-\rho_{\mathrm{fld}}}\right)$ \\
\hline - See Tables 3 and 4 for definitions and parameter values. \\
- $\mathrm{V}_{\text {shl }}$ is the shale volume calculated from either the gamma ray or SP logs \\
- Cenozoic shale properties: $\rho_{\mathrm{shl}}=2.403 \mathrm{~g} / \mathrm{cc} ; \Delta \mathrm{t}_{\mathrm{shl}}=59.998 \mu \mathrm{s} / \mathrm{ft}$ \\
- Paleozoic shale properties: $\rho_{\mathrm{shl}}=2.574 \mathrm{~g} / \mathrm{cc} ; \Delta \mathrm{t}_{\mathrm{shl}}=83.216 \mu \mathrm{s} / \mathrm{ft}$
\end{tabular}

Shale volume-corrected porosity should always be less than uncorrected porosity since shale causes porosity to calculate erroneously high. In some intervals, the shale volume-corrected sonic porosity was greater than the uncorrected porosity. This is likely due to the non-uniform nature of shale properties and the value of $\Delta t_{\text {shl }}$ used. Where the shale volume-corrected porosity calculated to be greater than the uncorrected porosity, the corrected porosity was discarded. Additionally, as discussed previously, shale volume was not calculated in volcanic rock intervals and therefore, in those intervals, the shale volume-corrected porosity is assumed equal to the uncorrected porosity. Shale volume-corrected density porosity calculated according to Equation 6 was used in all further calculations.

\section{Formation Temperature}

The only temperature information available from well 43-045-30001 were bottom hole temperatures recorded on the headers of the various log prints (see Table D-2). The maximum recorded bottom hole temperature in the well was used to define the temperature gradient in the well. Temperature over the depth of the well was determined by linear interpolation between the bottom hole temperature and the assumed surface temperature. As stated previously, no attempt was made to correct the bottom hole temperature for the affects of cooling during drilling.

\section{Formation Water Resistivity}

The well file identifies broadly-defined formations. These formations are listed in Table D-6 with their depths and short descriptions of rock type. Formation water resistivity was calculated for each of the formations individually. Geophysical log data is available only below approximately $470 \mathrm{ft}$. Therefore, formation water resistivities were calculated only in those formations falling below that depth. Within each formation, water chemistry was assumed to be constant and water resistivity was therefore allowed to vary only with temperature within each formation. 
Table D-6. Formations identified in the well file.

\begin{tabular}{|ll|}
\hline \multicolumn{1}{|c|}{ Description } & \multicolumn{1}{c|}{ Depths } \\
\hline Lake Sediments & $0-450$ \\
Alluvial deposit: conglomerate & $450-500$ \\
Volcanic Rocks & $500-1128$ \\
Tertiary Shale & $1128-1570$ \\
Tertiary Shale & $1570-2970$ \\
Paleozoic Carbonates & $2970-4270$ \\
\hline
\end{tabular}

Formation water resistivity was calculated using three different methods. The first method used is an algorithm put forth by Enikanselu and Adekanle (2008). Their algorithm is an adaptation of the method proposed by Bateman and Konen (1978) which allows formation water resistivity to be calculated based on the SP $\log$. The method requires the use of SSP and allows for the correction of SSP in thin beds.

Intervals were selected from each formation and the formation water resistivity was calculated using data from those intervals. Formation temperature was also taken from those intervals. Table D-7 gives the results of the calculations and the intervals from which data was taken in each of the formations for the calculation of formation water resistivity by the SP method. While the formation between 500 and $1128 \mathrm{ft}$ is mostly volcanic rock, the calculation of formation water resistivity was performed using data from a limestone interval.

Table D-7. Results of formation water resistivity calculations by the SP method.

\begin{tabular}{|lcccc|}
\hline \multicolumn{1}{|c}{ Description } & $\begin{array}{c}\text { Depths } \\
(\mathbf{f t})\end{array}$ & $\begin{array}{c}\text { Data Interval } \\
(\mathbf{f t})\end{array}$ & $\begin{array}{c}\mathbf{R}_{\mathbf{w}} \\
(\mathbf{o h m}-\mathbf{m})\end{array}$ & $\begin{array}{c}\text { Temp } \\
\left({ }^{\circ} \mathbf{F}\right)\end{array}$ \\
\hline Volcanic Rocks & $500-1128$ & $580-590$ & 0.093 & 72.7 \\
Tertiary Shale & $1128-1570$ & $1382-1386$ & 0.087 & 90.1 \\
Tertiary Shale & $1570-2970$ & $1655-1665$ & 0.083 & 96.2 \\
Paleozoic Carbonates & $2970-4270$ & $3862-3866$ & 0.017 & 144.2 \\
\hline
\end{tabular}

Jorgensen $(1989,1990)$ presents an algorithm similar to that of Bateman and Konen (1978) and reports that the method is only accurate to within plus or minus one half an order of magnitude. He also notes, however, that formation water resistivity may vary over three orders of magnitude and, in the absence of any better information, the SP method can be used to predict $\mathrm{R}_{\mathrm{W}}$.

Formation water resistivity was also calculated using the so-called $\mathrm{R}_{\mathrm{wa}}$ method. The apparent formation water resistivity, $R_{w a}$, can be calculated according to Equation 8 (Asquith, 1983):

$$
R_{w a}=\frac{R_{t}}{F}
$$

where $R_{t}$ is the true formation resistivity and $F$ is the formation factor. The formation factor is a function of rock type and porosity. The general form of the formation factor is (Asquith, 1983):

$$
F=\frac{a}{\phi^{m}}
$$

where $a$ is the tortuosity factor and $m$ is the cementation factor. In clean, water-saturated intervals, $R_{w}$ can be assumed equal to $R_{w a}$. However, Serra (1986) cautions that the results will be incorrect in the absence of water-bearing intervals, if the formation contains clay or if drilling 
fluids invade the formation deeply enough that they affect the measurement of true formation resistivity. Obviously, the results will be negatively affected by incorrect formation factor values.

The true formation resistivity, $R_{t}$, was taken from the deep-reading induction log. Porosity was taken from estimated shale volume-corrected density porosity values. Standard values of the Archie equation parameters $a$ and $m(\mathrm{a}=1 ; \mathrm{m}=2)$ were used in the calculation. Table $\mathrm{D}-8$ gives the results of the calculations and the intervals from which data was taken in each of the formations for the calculation of formation water resistivity by the $\mathrm{R}_{\mathrm{wa}}$ method. As stated previously, data for the formation water resistivity calculation in the volcanic rocks formation was taken from a limestone interval.

Table D-8. Results of formation water resistivity calculations by the $\mathrm{R}_{\mathrm{wa}}$ method.

\begin{tabular}{|lcccc|}
\hline \multicolumn{1}{|c}{ Description } & $\begin{array}{c}\text { Depths } \\
(\mathbf{f t})\end{array}$ & $\begin{array}{c}\text { Data Interval } \\
(\mathbf{f t})\end{array}$ & $\begin{array}{c}\mathbf{R}_{\mathbf{w}} \\
(\mathbf{o h m}-\mathbf{m})\end{array}$ & $\begin{array}{c}\text { Temp } \\
\left({ }^{\circ} \mathbf{F}\right)\end{array}$ \\
\hline Volcanic Rocks & $500-1128$ & $580-590$ & 0.087 & 72.7 \\
Tertiary Shale & $1128-1570$ & $1382-1386$ & 0.148 & 90.1 \\
Tertiary Shale & $1570-2970$ & $1655-1665$ & 0.131 & 96.2 \\
Paleozoic Carbonates & $2970-4270$ & $3862-3866$ & 0.016 & 144.2 \\
\hline
\end{tabular}

Finally, formation water resistivity was calculated using the cross-plot method as outlined in Hilchie (1982) and Jorgensen (1989). Using this approach, porosity values are plotted over resistivity values on a log-log plot (see Figure D-3). A best fit line is drawn through the data and extrapolated to the $100 \%$ porosity line. The extrapolated line intersects the $100 \%$ porosity line at the formation water resistivity value. In the present work, shale volume-corrected density porosity and deep-reading induction log resistivity were used in the analysis. Porosities below $1 \%$ and formation resistivities above $1000 \mathrm{ohm}$-meters were excluded as were values from intervals where the borehole was enlarged and other intervals in which the validity of the density $\log$ was questioned.

Since the cross-plot method estimates formation water resistivity through a regression scheme, the resultant $\mathrm{R}_{\mathrm{w}}$ value is a type of average over all the data points used in the analysis. However, the method assumes, among other things, that lithology is constant. Therefore, in each formation, only data from intervals of certain rock types were used. Other assumptions of the method include uniform water resistivity and $100 \%$ water saturation. Table D-9 contains the results of the calculations and also indicates the rock types involved in the analyses. The temperatures associated with each resistivity value are the average temperatures of the data included in the particular cross-plots and regression analyses.

Table D-9. Results of formation water resistivity calculations by the cross-plot method.

\begin{tabular}{|lcccc|}
\hline \multicolumn{1}{|c}{ Description } & \multicolumn{1}{c}{$\begin{array}{c}\text { Depths } \\
\text { (ft) }\end{array}$} & $\begin{array}{c}\text { Rock Types } \\
\text { Included }\end{array}$ & $\begin{array}{c}\mathbf{R}_{\mathbf{w}} \\
(\mathbf{o h m}-\mathbf{m})\end{array}$ & $\begin{array}{c}\text { Temp } \\
\left({ }^{\circ} \mathbf{F}\right)\end{array}$ \\
\hline Volcanic Rocks & $500-1128$ & Sediments $^{\mathrm{a}}$ & 0.063 & 75.8 \\
Tertiary Shale & $1128-1570$ & Sediments $^{\mathrm{a}}$ & 0.069 & 89.7 \\
Tertiary Shale & $1570-2970$ & Sediments $^{\mathrm{a}}$ & 0.044 & 96.2 \\
Paleozoic Carbonates & $2970-4270$ & Carbonates $^{\mathrm{b}}$ & 0.011 & 138.7 \\
\hline $\begin{array}{l}\text { a) Sandstone, siltstone, mudstone, claystone, chert, and conglomerate } \\
\text { b) Dolomite and limestone }\end{array}$
\end{tabular}


The formation water resistivities calculated using the three methods were then extrapolated over varying formation temperature within each formation according the standard equation (Asquith, 1983):

$$
R_{w}=R_{w, T_{1}} \frac{T_{1}+6.77}{T_{f}+6.77}
$$

where $R_{w, T l}$ is the formation water resistivity measured or calculated at a specific temperature $T_{1}$ and $R_{w}$ is the formation water resistivity as a function of formation temperature, $T_{f}$.

A comparison of the results of the three methods shows relatively good agreement. In each case, formation water resistivity is allowed to vary with temperature only with each formation. Table 10 lists the average formation water resistivity within each formation.

Table D-10. Comparison of the results of $\mathrm{R}_{\mathrm{w}}$ calculations from SP, $\mathrm{R}_{\mathrm{wa}}$ and cross-plot methods.

\begin{tabular}{|lllll|}
\hline \multirow{2}{*}{ Description } & \multirow{2}{*}{ Depths (ft) } & \multicolumn{3}{c|}{ Average $\mathbf{R}_{\mathbf{w}}$ by method (ohm-m) } \\
\cline { 3 - 5 } & & $\mathrm{SP}$ & $\mathrm{R}_{\mathrm{wa}}$ & Cross-plot \\
\hline Volcanic Rocks & $500-1128$ & 0.088 & 0.082 & 0.062 \\
Tertiary Shale & $1128-1570$ & 0.087 & 0.145 & 0.068 \\
Tertiary Shale & $1570-2970$ & 0.074 & 0.117 & 0.039 \\
Paleozoic Carbonates & $2970-4270$ & 0.018 & 0.017 & 0.011 \\
\hline
\end{tabular}

Of the results of the SP and $\mathrm{R}_{\mathrm{wa}}$ methods, Serra (1986) states that the $\mathrm{R}_{\mathrm{wa}}$ method is considered more accurate and indicates that the SP method should be used only as a last resort. However, both the SP and $\mathrm{R}_{\mathrm{wa}}$ methods are sensitive to the selection of data from individual intervals with which to perform the calculations. The cross-plot method, however, gives an average value of $\mathrm{R}_{\mathrm{w}}$. Since the methods show relatively good agreement and since the average formation water resistivity within a formation provided by the cross-plot method may be preferable to results from limited intervals within the formations, the results of the cross-plot method will be used in all further calculations and analyses.

\section{Water Saturation}

Water saturation, $S_{w}$, was calculated using three different methods. First, water saturation was calculated using Equation 11, originally published by Schlumberger (1975) for use in shaly formations:

$$
S_{w}=\frac{-\frac{V_{s h l}}{R_{s h l}}+\sqrt{\left(\frac{V_{s h l}}{R_{s h l}}\right)^{2}+\frac{\phi^{2}}{0.2 \cdot R_{W} \cdot\left(1.0-V_{s h l}\right) \cdot R_{t}}}}{\frac{\phi^{2}}{0.4 \cdot R_{W} \cdot\left(1.0-V_{s h l}\right)}}
$$

where $V_{s h l}$ is shale volume, $R_{s h l}$ is formation resistivity of a shale bed, $R_{w}$ is formation water resistivity, $R_{t}$ is formation resistivity and $\phi$ is porosity. Shale volume was determined, as outlined previously, as the minimum shale volume predicted by the gamma ray and SP methods. True formation resistivity $R_{t}$ was taken from the deep-reading induction log. The porosity used was the shale volume-corrected density porosity. The resistivity of the shale, $R_{\text {shl }}$, was taken as the deep-reading induction resistivity values averaged over the interval from 1135 to $1140 \mathrm{ft}$ for the 
Cenozoic section and from 3143 to $3145 \mathrm{ft}$ for the Paleozoic section. These are the same depth intervals from which density and acoustic wave travel time of shales were taken for use in the shale volume-corrected porosity equations.

Water saturation was next calculated according to the Archie equation (Asquith, 1983):

$$
S_{w}=\left(\frac{a}{\phi^{m}} \cdot \frac{R_{w}}{R_{t}}\right)^{1 / n}
$$

where $R_{t}$ and $R_{w}$ are the resistivities of the formation and formation water, respectively; $n$ is the saturation exponent and was assigned the standard value of 2; and $a$ and $m$ are the toruosity and cementation factors, respectively. Standard values of $a$ and $m(\mathrm{a}=1 ; \mathrm{m}=2)$ were used. Porosity in the Archie equation was taken from the shale volume-corrected density porosity and formation resistivity was taken from the deep-reading induction resistivity log, as discussed previously.

Finally, water saturation was calculated using the ratio method as outlined in Asquith (1983). The ratio method allows for the calculation of water saturation based exclusively on resistivity data according to Equation 13:

$$
S_{w}=\left(\frac{R_{x o} / R_{t}}{R_{m f} / R_{w}}\right)^{0.625}
$$

Here, $R_{x o}$ is the resistivity of the flushed zone and can be read from a shallow-reading resistivity $\log ; R_{m f}$ is the resistivity of the mud filtrate. For the present calculations, resistivity of the flushed zone was taken from the Laterlog-8 $\log$. Resistivity of the mud filtrate was read from the resistivity $\log$ header and extrapolated over varying temperature. $R_{w}$ and $R_{t}$ are as described previously.

Asquith (1983) cautions that one of the difficulties with shaly formation analysis is the determination of shale resistivity. In the present application of the shaly formation equation (Equation 11), a single value of $\mathrm{R}_{\text {shl }}$ was used in calculating water saturation throughout the Cenozoic section of the well and another value of $\mathrm{R}_{\text {shl }}$ was used for calculations in the Paleozoic section, thus assuming that shale properties remain essentially unchanged through the two sections, an assumption that is likely not fully justified. Nevertheless, the water saturations calculated by the shaly formation equation compare reasonably well with the saturations calculated by the other methods.

The shaly formation equation and the Archie equation yield results that are qualitatively similar through much of the well with the Archie equation yielding water saturations generally higher than those calculated by the other methods. The saturations calculated from the ratio method are generally the lowest and saturations from the shaly formation equation are typically intermediate between the saturation values from the other methods. The water saturations estimated by the shaly formation equation were used in all further calculations.

Bulk volume of water was calculated according to Equation 14:

$$
B V W=S_{W} \cdot \phi
$$


In bulk volume of water calculations, water saturation was taken from the shaly sand equation and porosity was taken as the shale volume-corrected density porosity. When the water saturation was calculated to be greater than 1, the maximum value of 1 was imposed.

Both the $\mathrm{R}_{\mathrm{wa}}$ and cross-plot methods of calculating formation water resistivity and all three methods of calculating water saturation rely upon the true formation resistivity, a value that may be obtained from the deep-reading induction log. However, in some cases (thin, resistive beds) the deep-reading resistivity log may not give an accurate reading of true formation resistivity. Charts exist for the correction of the deep-reading resistivity log; however, when the data were examined in comparison with the correction charts, it was concluded that no correction was necessary.

\section{Permeabililty}

Permeability was calculated according to the empirical model of Jorgensen (1989). Jorgensen developed his model by curve-fitting experimentally-derived permeabilities. The samples used in the regression exhibited permeabilities between $4.5 \mathrm{mD}$ and 1.1 D. The model defines an approximate relationship between permeability and porosity and cementation factor (Equation 15):

$$
k=1.828 \cdot 10^{5}\left(\frac{\phi^{(m+2)}}{(1-\phi)^{2}}\right)^{1.10}
$$

where $\phi$ is porosity in fractional units, $m$ is the cementation factor and $k$ is the permeability in milli-Darcies.

The model also matches typical values of cementation factor, porosity and permeability for various lithologies including carbonates. Jorgensen states that the model is applicable to sandstone, siltstone and most porous carbonates. The model was applied in volcanic intervals even though Jorgensen gives no indication about the appropriateness of the model for volcanic rocks.

In the present application, the shale volume-corrected density porosity was used. When Jorgensen did his original work, he used cementation factors unique to each sample; however, the permeability calculations reported here were performed for the whole depth of the well using the standard value $m=2$.

\section{Results of Analysis of Well 43-045-30001}

The results of the calculations of porosity, water saturation and matrix permeability are shown plotted with respect to depth in Figures D-4, D-5, and D-6. Logs can be adversely affected by borehole effects when the wellbore is out of gauge. The caliper log was used to identify intervals in which the wellbore was enlarged. The data from these intervals and other intervals in which the log data were deemed suspect are not included in the plots.

The porosity data presented here is the shale volume-corrected density porosity (see Equation 6) as pore volume per total volume. Porosities in the Paleozoic section (below $2970 \mathrm{ft}$ ) range from $15 \%$ to less than zero. Negative values in the limestones indicate that the limestone matrix density value used in calculating porosity is less than the actual value. In contrast, porosities in the Cenozoic section of the well range from $15 \%$ to over $40 \%$. Estimated porosities 
in the volcanic rocks range from near $10 \%$ to just over $35 \%$, but values above $30-35 \%$ are uncommon and must be viewed with caution.

Water saturation was calculated using the shaly formation equation (see Equation 11) and has units of liquid-filled porosity volume per total porosity volume. Calculated water saturations range from $40 \%$ to $100 \%$ in the Cenozoic section. In the Paleozoic rocks, calculated water saturations are much lower, ranging from approximately $10 \%$ to $80 \%$, with the majority falling below about 50\%. These values are lower than expected but the reason for this is unknown.

The estimated matrix permeability data presented here were calculated according to the model of Jorgensen (see Equation 15) and are shown in units of milli-Darcies. Matrix permeabilities in the Cenozoic section range from approximately $10 \mathrm{mD}$ to more than $10 \mathrm{D}$. Because permeability was determined from porosity, in intervals in which estimated porosities are likely unreliable (greater than 30-35\%), the permeabilities derived from these high porosities (eg. greater than 3 D) are also questionable. Furthermore, prediction of permeability outside the range of data used by Jorgensen in developing his model $(4.5 \mathrm{mD}$ to $1.1 \mathrm{D})$ may not be justified. In general, all calculations of parameters in the Cenozoic section of the well must be considered approximate only. Permeabilities estimated in the Paleozoic section were much lower, generally below $100 \mathrm{mD}$. The permeabilities reported here estimate matrix permeability and likely do not reflect any fracture permeability which might be present.

The graphical representations of the well logs, including calculated logs of porosity, water saturation and permeability can be found in Appendix B.

\section{Summary of Results for Well 43-045-30001}

- Estimated average porosities in the Cenozoic section of the well range from 15 to $40 \%$ but results greater than $30-35 \%$ may be unreliable. The calculated porosities range from $15 \%$ to less than $0 \%$ in the Paleozoic section. There is an overall decrease in porosity with depth from 2970-3500 ft. At greater depths, porosities are less than 10\%.

- The estimated average permeabilities in the Cenozoic section range from greater than $10 \mathrm{mD}$ in to more than $10 \mathrm{D}$, however, calculated values above $1 \mathrm{D}$ are suspect. Estimated permeability in the Paleozoic section decreases in the shallow intervals of the section and is more stable in the deeper intervals. Permeabilities are generally less than $100 \mathrm{mD}$ in the shallow interval of the Paleozoic section and below $10 \mathrm{mD}$ in the deeper interval.

- As discussed previously, data from the Cenozoic section of well 43-045-30001 is suspect and all results from the Cenozoic section must be considered approximate only.

\section{Analysis of Well 43-045-11076}

\section{Methodology}

Well 43-045-11076 was drilled in 1956, making it one of the oldest wells among the seven discussed previously. Well logs were run in the well but a different suite of logging tools was used, thus requiring a different analytical approach. 


\section{Well Log Suite}

The log suite from well 43-045-11076 consists of an old style Gamma Ray / Neutron log and an Electrical log. The former log records the gamma ray response as micro-grams of radonequivalent per ton. The neutron response of the old style Gamma Ray / Neutron log is reported in counts per second. Newer neutron porosity logs report a calculated porosity as volume per volume.

The old style Electrical log run in well 43-045-11076 consists of spontaneous potential, normal, long normal and lateral logs. The former three logs record the resistivity of the formation; the spontaneous potential log is comparable to modern SP logs.

\section{Shale Volume}

Shale volume was calculated according to the procedure discussed previously in reference to well 43-045-30001. As before, shale volume was not calculated in intervals described as containing volcanic rocks. An SP log baseline correction was performed in much the same way as was done in well 43-045-30001 (see Figure D-7). In well 43-045-11076, the relative resistivities of the drilling mud and the formation water resulted in an inversion of the SP curve; here, the SP shale baseline falls on the left and permeable intervals are indicated by deflections to the right.

\section{Correlation with Well 43-045-30001}

Well 43-045-11076 is located approximately seven miles west southwest of well 43-045-30001. The two wells are separated by a southwest trending normal fault down to the northwest. They display similar stratigraphic relationships.

The gamma ray logs from the two wells were recorded in different units (micro-grams of radon-equivalent per ton in well 43-045-11076 and API units in well 43-045-30001). To allow for comparison, the gamma ray curves were scaled between 0 and 1 and plotted on the same set of axes. The gamma ray signatures show a reasonable correlation when 43-045-11076 is offset vertically by $950 \mathrm{ft}$. Figure D- 8 shows the gamma ray curves of the two wells before and after the 950-ft depth shift.

\section{Neutron Porosity}

Modern neutron porosity logs present porosity as volume per volume or percent. The old style of neutron logs, such as that recorded in well 43-045-11076, however, present neutron data as counts per second. Schechter (2003) reports on the method of D. E. Shier which defines a relationship between neutron logs and neutron log-derived porosity that allows porosity to be estimated from neutron counts per second.

Shier's equation relies upon correlating intervals of high and low porosity between wells. In a well in which porosity is known (the reference well), intervals of high and low porosity are identified. Correlative intervals are then identified in the well in which only an old style neutron $\log$ is available. High porosity corresponds to low neutron counts per second and low porosity corresponds to high neutron counts per second. If correlative intervals can be identified in the wells, then the porosity (volume per volume) can be estimated in the well in which only a neutron log (counts per second) was obtained. Shier's equation is given by the expression: 


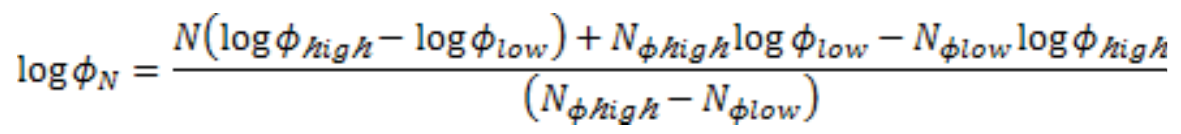

where $N$ is the neutron log value (in counts per second) and $\phi_{N}$ is the estimated neutron porosity. The other parameters in the equation are found from the high- and low-porosity intervals that can be correlated between the wells: $\phi_{\text {high }}$ and $\phi_{\text {low }}$ are the porosities observed in high and low porosity intervals in the reference well; $N_{\phi h i g h}$ and $N_{\phi l o w}$ are the neutron log values (in counts per second) in the correlative intervals of the well in which only the neutron log is recorded.

In the present analysis, the approach was somewhat different. Rather than identifing intervals of high and low porosity in well 43-045-30001 and attempting to correlate them with intervals in well 43-045-11076, maximum and minimum porosities reasonably expected were selected. Values of $\phi_{\text {high }}=0.35$ and $\phi_{\text {low }}=0.05$ were selected based on results from well 43-045-30001. The maximum neutron log value (corresponding to $\phi_{\text {low }}=0.05$ ) was $\mathrm{N}_{\phi l o w}=314$ counts per second; the minimum neutron $\log$ value (corresponding to $\phi_{\text {high }}=0.35$ ) was $\mathrm{N}_{\phi \text { high }}=166$ counts per second. The porosities in well 43-045-11076 were than calculated using Equation 16.

The presence of shale in a formation can result in erroneously high porosity values. Although the shale volume in the well was calculated, no attempt was made to correct for shale effects on the estimated porosity values.

\section{Permeability}

Permeability in well 43-045-11076 was calculated from the estimated porosity using Jorgensen's model (see Equation 15) as described previously. As in well 43-045-30001, the Archie equation cementation factor $m$ was assumed equal to 2 throughout the depth of the well.

\section{Results}

Porosities in well 43-045-11076 were estimated using Equation 16 and are shown in Figure D-9. Figure D-10 is a comparison of wells 43-045-11076 and 43-045-30001 showing the porosities from well 43-045-11076 after the depth offset.

Permeabilities were approximated by the Jorgensen model (see Equation 15) based on the estimated porosities (see Figure D-11). As discussed previously in relation to well 43-045-30001, prediction of permeabilities outside the range of data used in development of Jorgensen's model $(4.5 \mathrm{mD}$ to $1.1 \mathrm{D})$ may not be justified. The permeabilities predicted by the Jorgensen model represent matrix permeability and do not account for any fracture permeability that might be present.

\section{Summary of Results for Well 43-045-11076}

- Because appropriate logs were not available, maximum and minimum porosities of 35 and $5 \%$ were utilized based on results from well 43-045-30001. Calculated porosities vary with depth and rock type. Between 750 and $1500 \mathrm{ft}$ (Cenozoic sedimentary rocks), the average calculated porosities decrease from $30 \%$ to $20 \%$. Between 1500 and $2700 \mathrm{ft}$ (Cenozoic volcanic rocks), the calculated porosities remain relatively stable at about $20 \%$. Below $2750 \mathrm{ft}$, porosities in the volcanic rocks decrease to between 5 and $10 \%$. 
- Permeabilities decrease slowly with depth paralleling changes in the calculated porosity. Values range from over $1 \mathrm{D}$ to $100 \mathrm{mD}$ in the sedimentary interval (750-1500 ft) to between $100 \mathrm{mD}$ and $1 \mathrm{D}$ in the shallow volcanic rocks (1500-2700 ft). Permeabilities range from 1 and $10 \mathrm{mD}$ in the deep volcanic rocks (below $2750 \mathrm{ft}$ ). Calculated permeabilities greater than $1 \mathrm{D}$ may be unreliable.

\section{Conclusions}

Porosities, permeabilities and water saturations were calculated for two wells near Focus Area 1. The stratigraphic section consists of Cenozoic sediments and volcanic rocks lying above Paleozoic rocks dominated by carbonates. Well 43-045-30001 penetrated the Paleozoic rocks; well 43-045-11076 did not reach the Paleozoic sequence. In general, porosity and permeability decrease with depth. Porosities typically vary from 35 to $15 \%$ in the Cenozoic section and are less than $15 \%$ in the Paleozoic section. Permeabilities range from $10 \mathrm{mD}$ to greater than $1 \mathrm{D}$ in the Cenozoic section with values greater than $1 \mathrm{D}$ being suspect. Permeabilities in the Paleozoic section are much lower, typically between 100 and $0.1 \mathrm{mD}$. Permeabilities at the upper end of this range are sufficiently high to support natural geothermal systems, consistent with geochemical data suggesting that limestones host the geothermal system in this area.

\section{References}

Asquith, G., and C. Gibson, 1983, Basic Well Log Analysis For Geologists, AAPG Methods in Exploration Series, Number 3, AAPG, Tulsa, OK, USA.

Bateman, R. M., and C. E. Konen, 1978, "The Log Analyst and the Programmable Pocket Calculator," The Log Analyst, 19(3), 3-11.

Dresser Atlas, 1979, Log Interpretation Charts, Dresser Industries, Inc., Houston, TX, USA.

Enikanselu, P. A., and A. Adekanle, 2008, "A Fortran Programme for Computing Formation (Connate) Water Resistivity from Spontaneous Potential Logs," American-Eurasian Journal of Scientific Research, 3(2), 172-177.

Hess, R. H., M. A. Henson, D. A. Davis, S. H. Limerick, S. S. Siewe, and M. Niles, 2011, Oil and Gas Well Information for Nevada-2011 Update, NBMG Open-File Report 11-6, Nevada Bureau of Mines and Geology, [Available at: http://www.nbmg.unr.edu/Oil\&Gas/ScannedWellLogs.html].

Hilchie, D. W., 1982, Applied Openhole Log Interpretation for Geologists and Engineers, Douglas W. Hilchie, Inc., Golden, CO, USA.

Jorgensen, D. G., 1989, Using Geophysical Logs to Estimate Porosity, Water Resistivity, and Intrinsic Permeability, USGS Water-Supply Paper 2321, US Geological Survey.

Jorgensen, D. G., 1990, “Estimating Water Quality from Geophysical Logs,” in: Frederick L. Paillet and Wayne R. Saunders, eds., Geophysical Applications from Geotechnical Investigations, ASTM STP 1101, American Society of Testing and Materials, Philadelphia, PA, USA. 
Schechter, D. S., 2003, Preferred Waterflood Management Practices for the Spraberry Trend Area - Semi-Annual Technical Progress Report, DOE Contract No. DE-FC26-01BC15274 Texas A\&M University, [Available at:

http://www.pe.tamu.edu/schechter/baervan/Reports/Preferred\%20Waterflood.pdf]

Schlumberger, 1974, Log Interpretation Manual/Applications, Vol. II, Schlumberger Well Services, Houston, TX, USA.

Schlumberger, 1975, A Guide to Well Site Interpretation of the Gulf Coast, Schlumberger Well Services, Houston, TX, USA.

Serra, O., 1986, Fundamentals of Well-log Interpretation: 2. The Interpretation of Logging Data, Developments in Petroleum Science, 15B, Elsevier, Amsterdam, the Netherlands.

Smith, R. P., Breckenridge, R. P., and Wood, T. R., 2011, "Preliminary Assessment of Geothermal Potential at the UTTR," INL/EXT-11-22215, Rev. 0, Idaho National Laboratory external report, Idaho Falls, ID, USA.

Utah Division of Oil, Gas and Mining, 2011, LiveData Search - Online Oil and Gas Information System, [Available at:

http://oilgas.ogm.utah.gov/Data_Center/LiveData_Search/main_menu.htm]. 


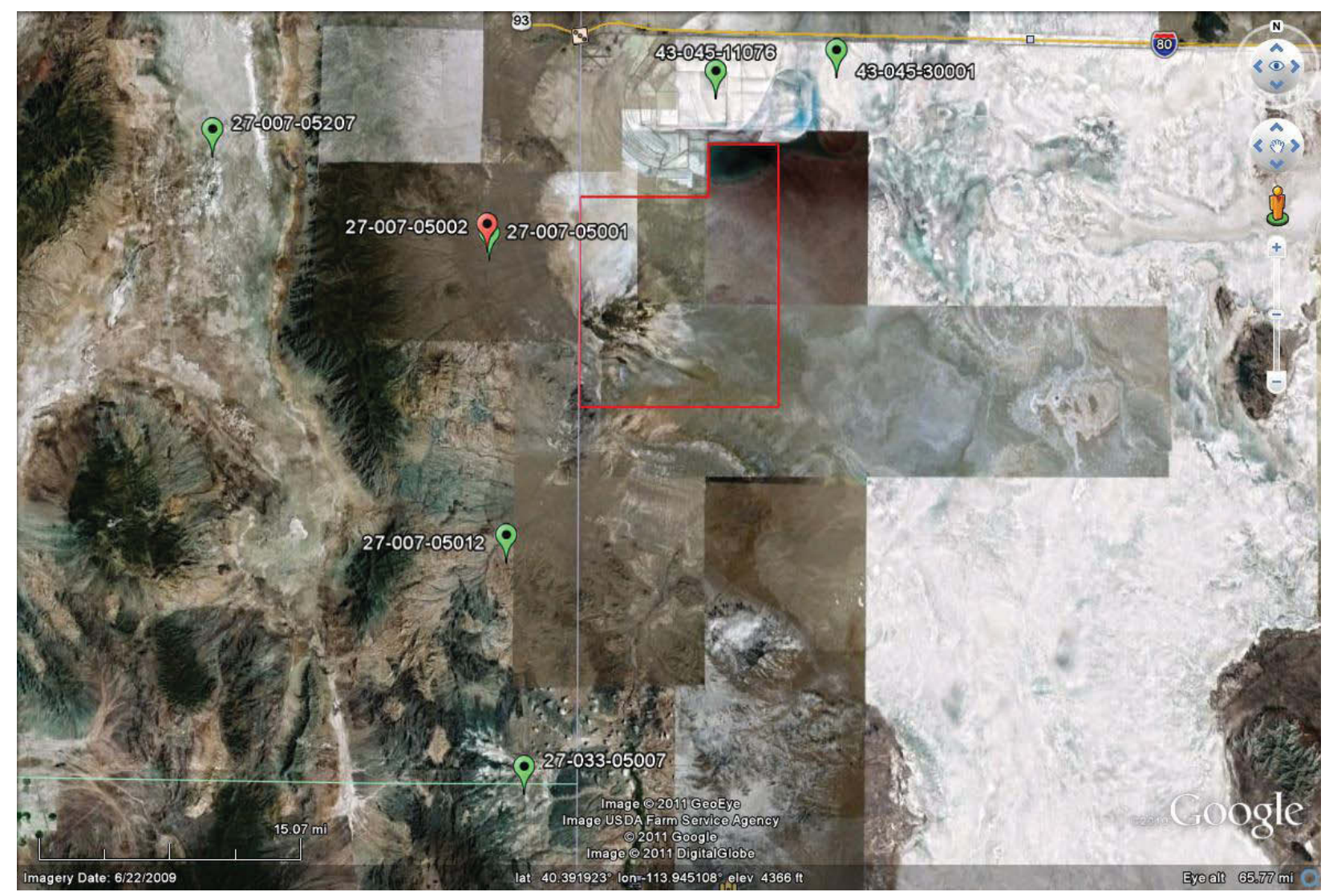

Figure D-1. Google Earth satellite image showing the seven oil and gas wells in relation to Focus Area 1, which is outlined in red. 


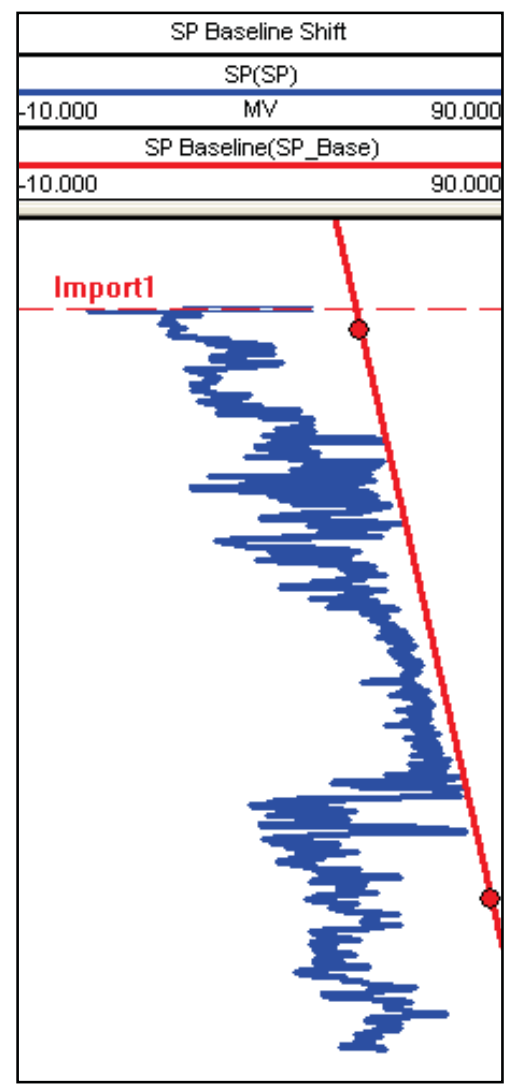

Figure D-2. GeoGraphix PRIZM ${ }^{\mathrm{TM}}$ was used to perform a baseline correction operation. The original SP curve appears in blue and the new baseline is shown in red.

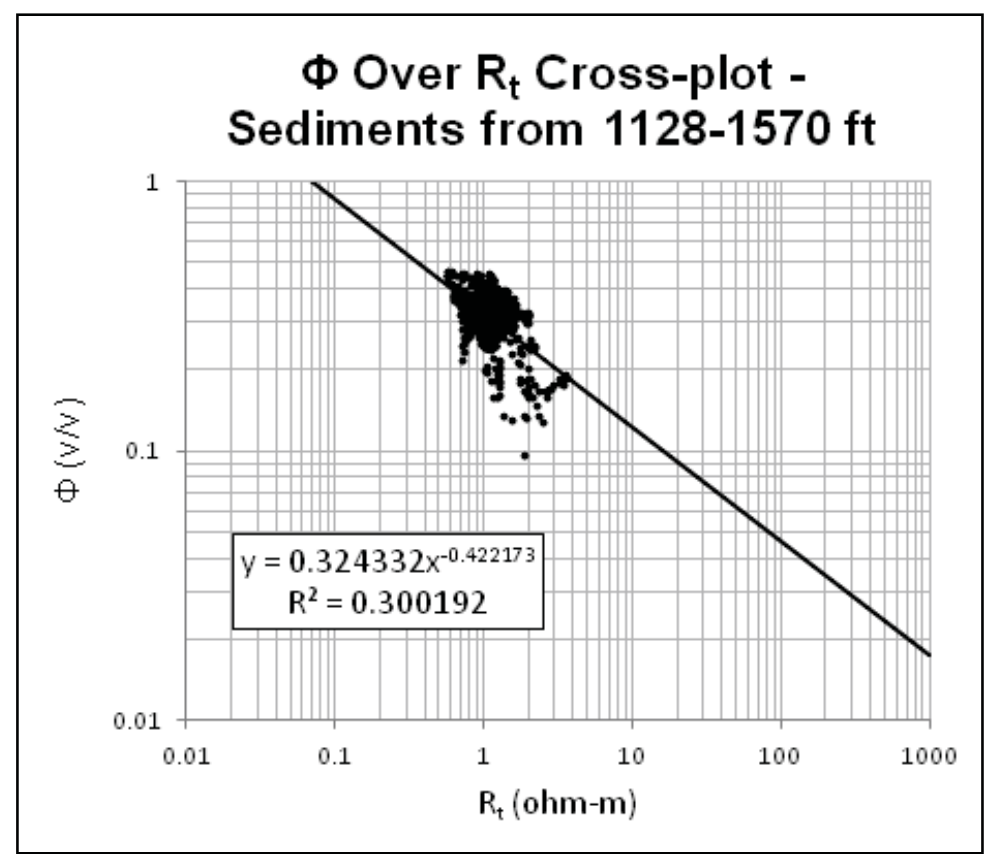

Figure D-3. Porosity-resistivity cross-plot with a regression line extrapolated to the $100 \%$ saturation line, indicating the formation water resistivity value. Plots such as this were generated for each formation. 


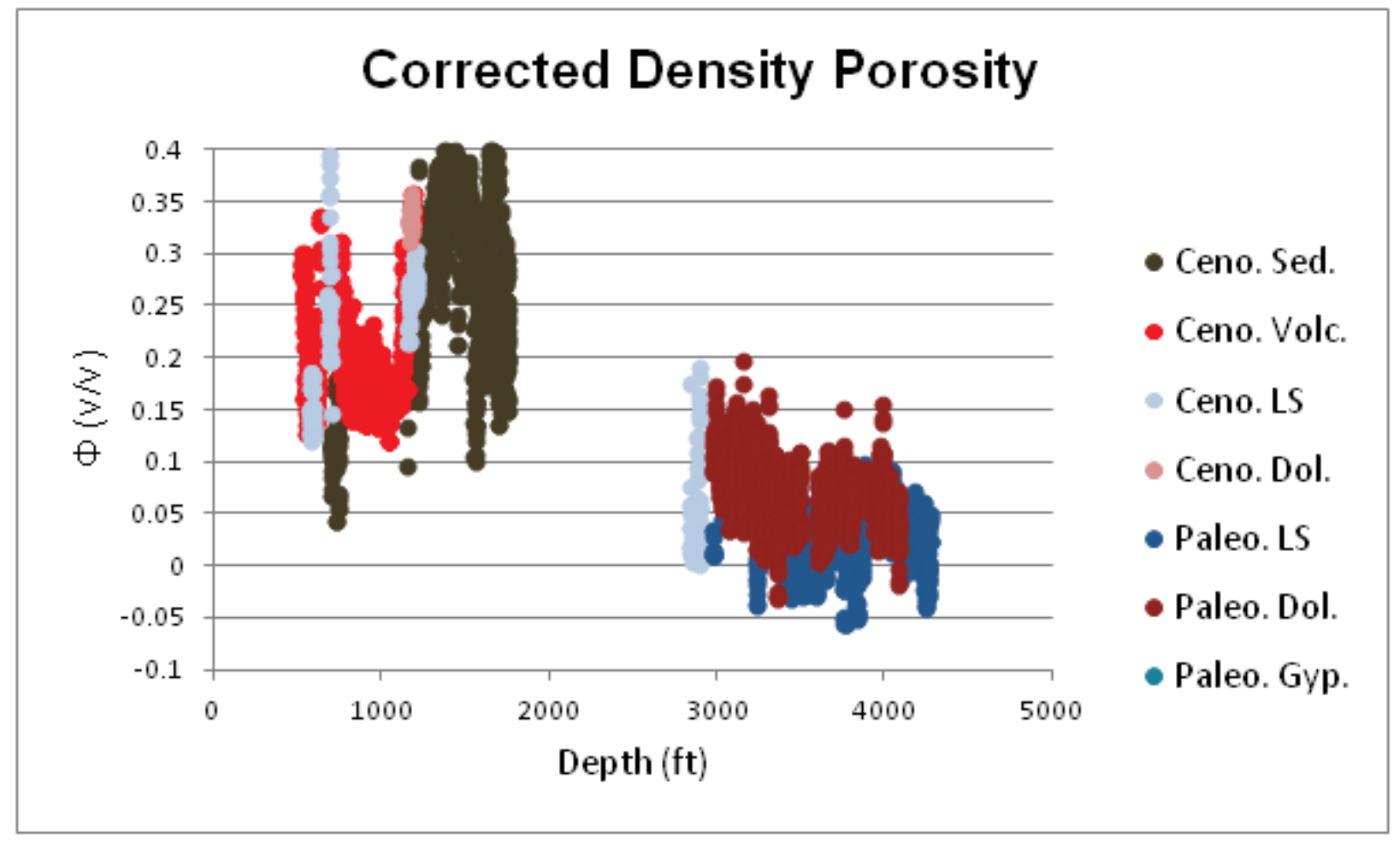

Figure D-4. Shale volume-corrected density porosity as volume per volume (v/v) with respect to depth for well 43-045-30001. Porosities above 35\% are uncommon. Porosities greater than 30-35\% are suspect (see text).

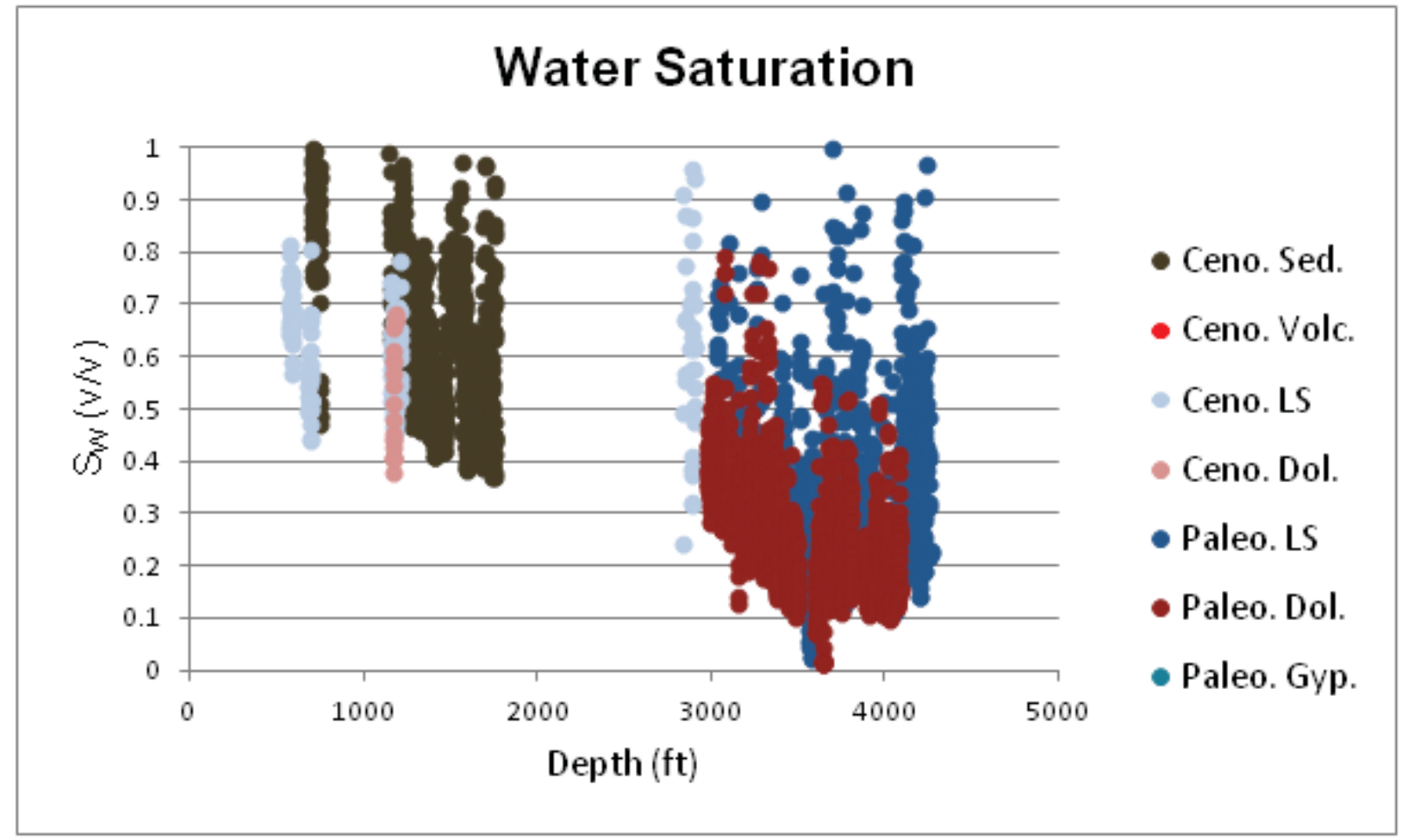

Figure D-5. Water saturation with respect to depth for well 43-045-30001. 


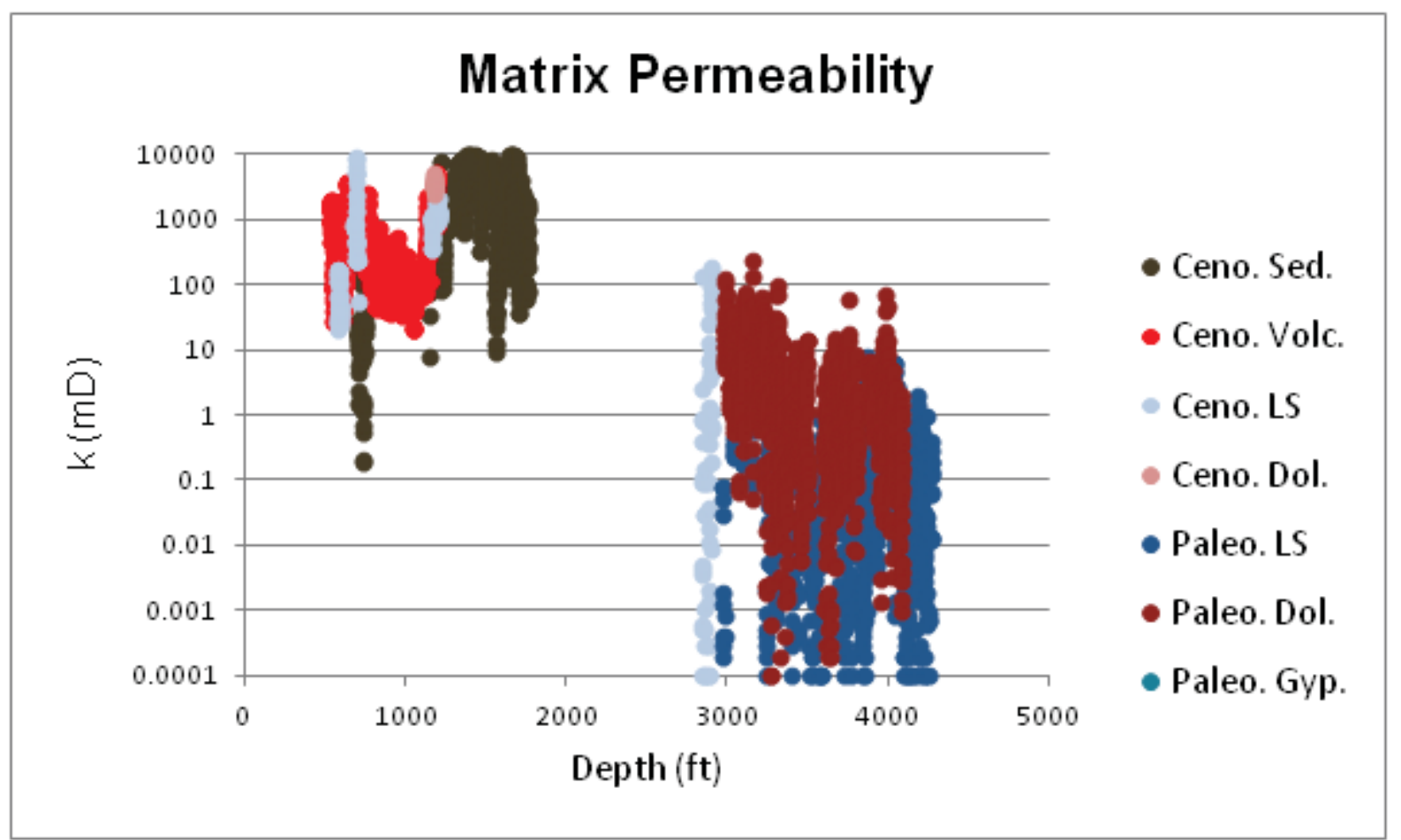

Figure D-6. Matrix permeability with respect to depth for well 43-045-30001. Permeability was calculated as a function of porosity. Calculated permeabilities greater than $1 \mathrm{D}$ are suspect (see text). 


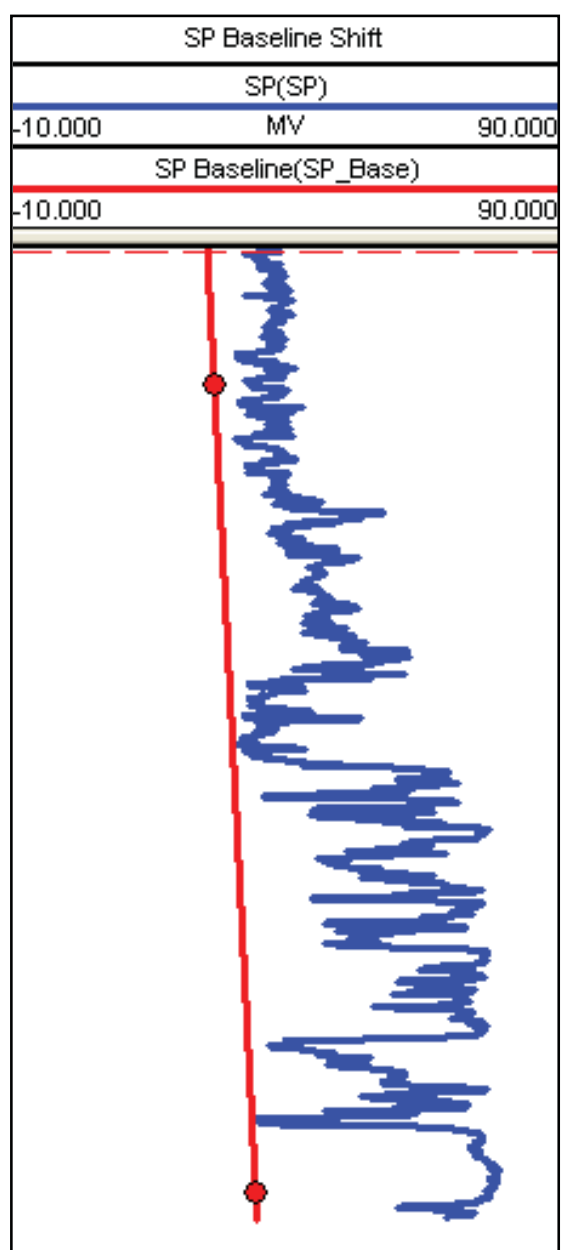

Figure D-7. Measured SP response (blue) and the corrected baseline (red). In this case, due to the relative resistivities of the drilling mud and the formation water, the SP shale baseline is on the left and deflection to the right indicates clean intervals. 

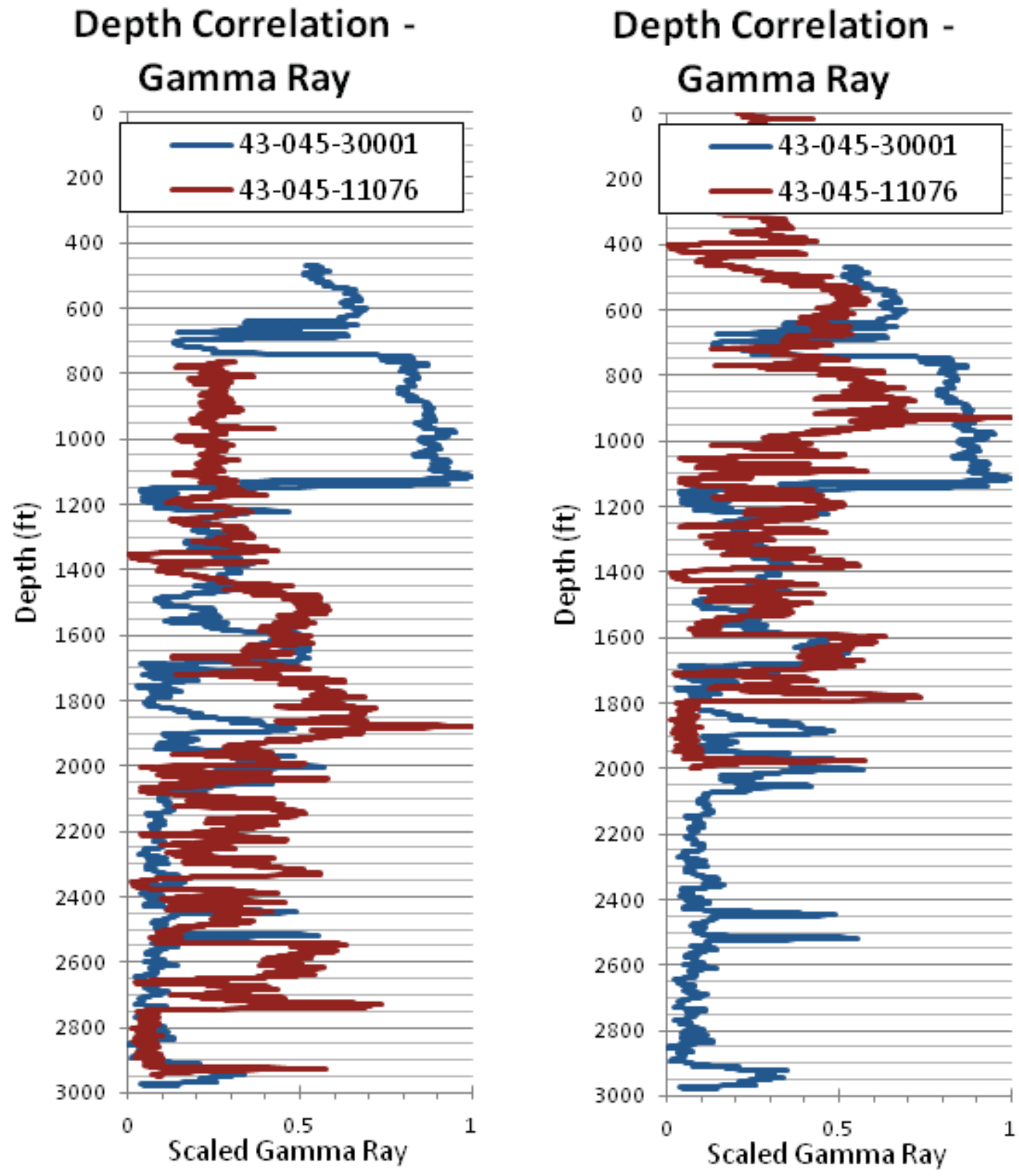

Figure D-8. Gamma ray responses from wells 43-045-11076 and 43-045-30001. a) Gamma ray curves before correction for fault offset. b) Gamma ray curves after 950-ft offset. 


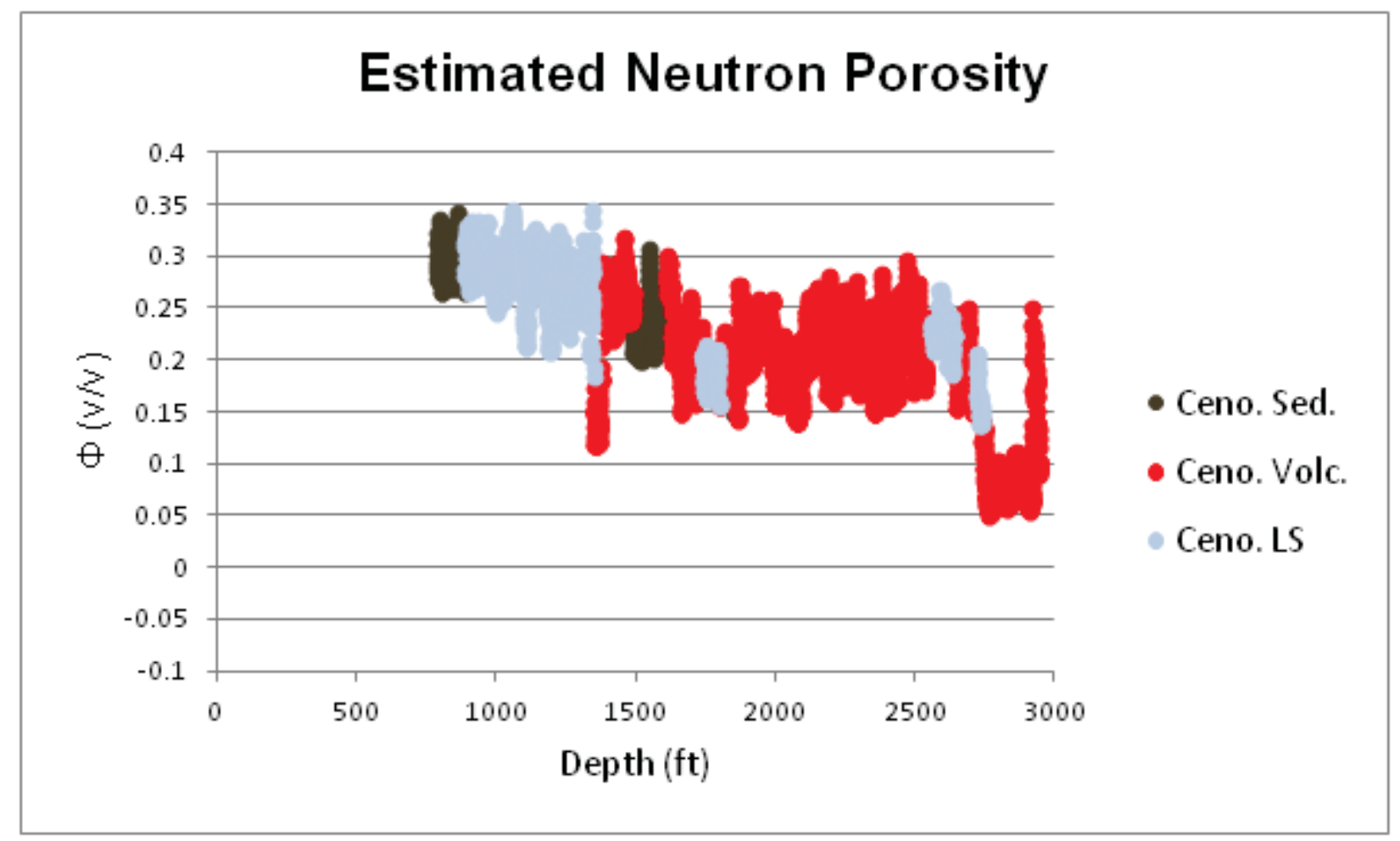

Figure D-9. Estimated neutron porosity as volume per volume (v/v) with respect to depth from well 43-045-11076. Porosities were estimated according to Equation 16. High- and low-porosity values were selected somewhat arbitrarily. 


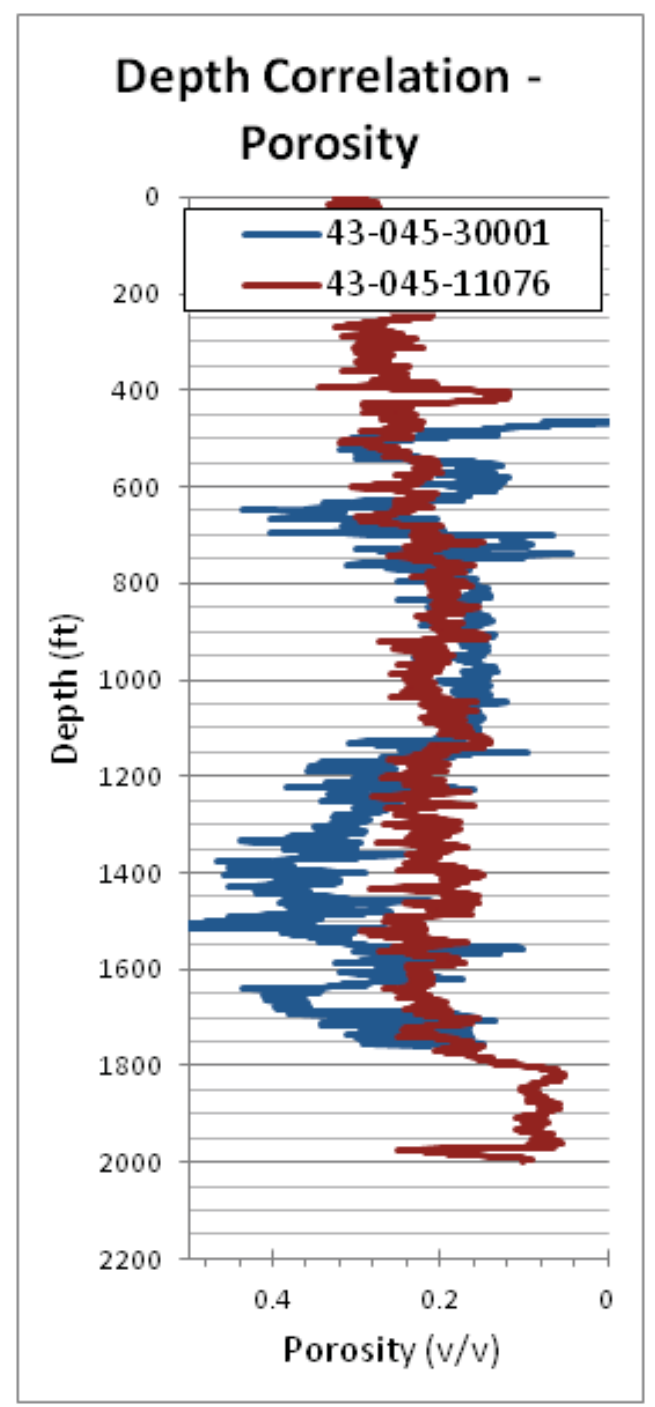

Figure D-10. Comparison of porosities (as volume per volume) between wells 43-045-30001 and 43045-11076 after the 950-ft depth offset. The figure shows good correlation, particularly between 500 and $900 \mathrm{ft}$. 


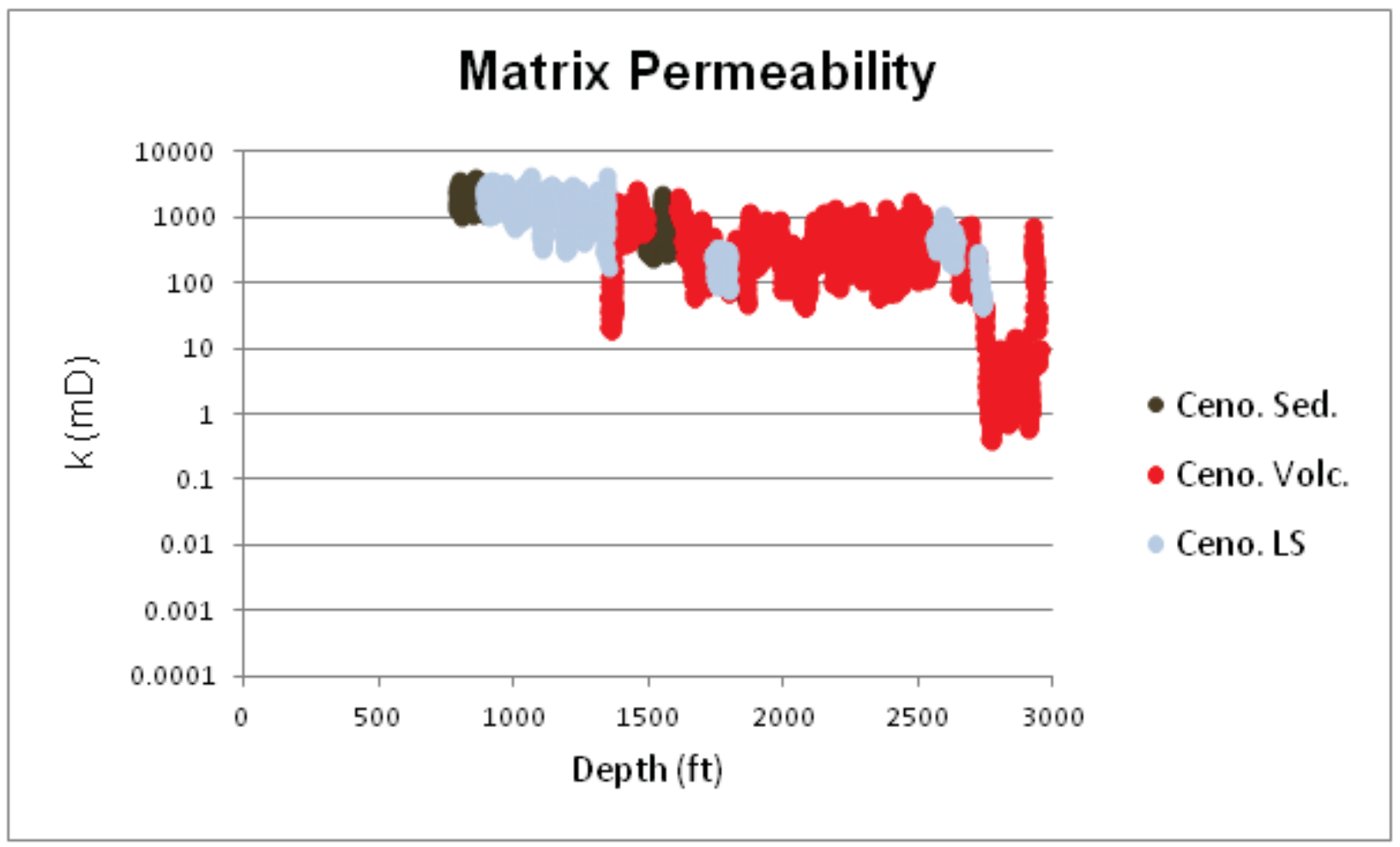

Figure D-11. Matrix permeability calculated from the estimated porosities using Jorgensen's model. 


\title{
Appendix E
}

\section{Sample and Analysis of Surface Water and Springs}

\author{
Joseph Moore $^{1}$, Thomas Wood ${ }^{2}$, and Robert Breckenridge ${ }^{2}$ \\ ${ }^{1}$ Energy and Geoscience Institute \\ ${ }^{2}$ Idaho National Laboratory
}

\section{Spring and Well Water Sampling}

Thermal waters discharge at several locations in and adjacent to the West Desert of Utah. Analysis of thermal waters can lead to an understanding of the thermal history of the water and give an indication of the deep reservoir conditions. Nine samples were collected; four from the Blue Lake area and five from wells located on the southeast flank of the Silver Island Mountains (see Figure E-1 and Attachment E-1). Samples from these sites were collected on September 28, 2011. Samples were also taken from two locations at Mosquito Willy's springs, located approximately $3.6 \mathrm{~km}$ south of Blue Lake, on January 31, 2012. As a standard procedure, temperature and $\mathrm{pH}$ were measured at each location during sampling. Temperatures were measured using a Yokogawa TX10 temperature probe. The $\mathrm{pH}$ was measured using a Hanna Instruments combined $\mathrm{pH} / \mathrm{EC}$ meter that was calibrated the previous day. Three water samples were collected at each sample location: a $500 \mathrm{ml}$ sample of filtered water, a $25 \mathrm{ml}$ sample of filtered water diluted with $225 \mathrm{ml}$ of distilled water, and a $500 \mathrm{ml}$ sample of unfiltered water. The samples were filtered using a peristaltic pump and 0.45 micrometer filter. Sample locations (UTM easting and northing) and elevations were determined using a handheld Garmin GPSMAP 62st device. The water samples were shipped to Thermochem, Inc., Santa Rosa, CA, for analysis.

A suite of geothermometers was calculated for each of the water analyses to estimate temperatures within the geothermal reservoir. Although many geothermometers have been proposed and are widely in use, most have been calibrated for high temperature environments and for reservoir rocks containing feldspars and clays and quartz. Consequently, it cannot be assumed these geothermometers will yield reliable results for waters that have interacted with limestone and dolomite reservoirs, such as those being evaluated in this study. Furthermore, the application of most geothermometers is based on the assumption that the elemental ratios and silica concentrations have not changed since the fluid left the reservoir. These changes may result from re-equilibration or dilution. For the low temperature springs and wells sampled in this study, this assumption may not be valid. The most commonly utilized geothermometers for estimating reservoir temperatures from the chemistries of low- to moderate-temperature spring and well discharges include the silica geothermometers (Fournier, 1981), although these geothermometers may be strongly affected by dilution of low silica waters, the K- Na-Mg geothermometer of Giggenbach (1991), and the anhydrite geothermometer (T. Powell, person. comm., 2011). In addition, the $\mathrm{Na} / \mathrm{Li}$ geothermometer of Kharaka et al. (1982) has been applied. 


\section{Intrepid Potash Inc. Well Samples}

Water samples were collected from five wells located between 2 and $3.5 \mathrm{~km}$ north of Interstate 80 (see Figure E-2 and Table E-1). These wells produce water with temperatures of $25.8-32.8^{\circ} \mathrm{C}$ and are reported to be $60 \mathrm{~m}$ deep (R. Draper, Intrepid Potash Inc., pers. comm. 2011). The wells produce from fluids that discharge into the shallow alluvial aquifer along the Silver Island range-front fault. Static water levels are reported to be approximately $15-20 \mathrm{~m}$ deep.

\section{Blue Lake Thermal Area}

Blue Lake is located approximately $25.8 \mathrm{~km}$ south of Wendover, Nevada (see Figure E-1). It is a deep natural spring fed lake, with a depth of approximately $18 \mathrm{~m}$. Springs discharge thermal water into the bottom of the lake, but the inflow is diffuse and direct sampling of the springs has never been successfully accomplished. Bottom temperatures are approximately $29^{\circ} \mathrm{C}$. The area surrounding the lake is characterized by wetlands and ponds of various sizes fed by thermal springs. To our knowledge, there are no deposits (e.g. silica or carbonate) related to the discharge of thermal water in this area.

Water samples were taken from four locations around Blue Lake (see Figure E-3 and Table E-1). Blue Lake \#1 was collected directly from a spring at the south end of a large pond. The sample location is $1 \mathrm{~km}$ west-southwest of Blue Lake. Blue Lake \#2 was collected on the north shore of Blue Lake. Measured temperatures $\left(28^{\circ} \mathrm{C}\right)$ were slightly warmer at the sample location than at other shoreline locations in the vicinity, and a mound below the surface of the water about $2 \mathrm{~m}$ from the shore suggest that the sample location is near a spring; however, no direct evidence of discharging thermal water was observed. Blue Lake \#3 was collected from the floating dock on the west shore of Blue Lake. Temperatures at the sample location decreased from $27.2-26.6^{\circ} \mathrm{C}$ during the 10 minute sampling period, perhaps due to natural circulation of the lake water. Blue Lake \#4 was collected from a pond west of Blue Lake. There was no evidence of a spring at the sample site.

\section{Mosquito Willy's Springs}

Mosquito Willy's Springs are located approximately $3.5 \mathrm{~km}$ south of Blue Lake in Tooele County, Utah inside the Utah Test and Training Range. Discharge occurs at two locations separated by approximately $130 \mathrm{~m}$. At the north spring, discharge is into a shallow pond $1-2 \mathrm{~m}$ deep, $8 \mathrm{~m}$ wide, and $25 \mathrm{~m}$ long. Water temperature was measured to be $26.9^{\circ} \mathrm{C}$. At the south spring, water discharges into a reed-filled depression approximately the same size as the north spring. Discharge rates at the south spring appear to be significantly lower and temperature was measured to be $26.8^{\circ} \mathrm{C}$.

Samples were collected from each discharge site (see Figures E-4 through E-12 and Table E-1). At the north pond, water was collected from the southern-most of two discharge orifices. At the southern spring, discharge rates and temperatures varied among at least five different discharge orifices. Measurements were conducted and samples collected from the best flowing and warmest discharge orifice. 


\section{Results}

The results of the chemical analyses are presented in Table E-1. The samples were analyzed for major, minor, and several trace elements using standard chemical techniques by Thermochem, Inc. The analytical results are included in Attachment E-1. The charge balance as a percentage of the total ionic charge of the solution ((cations - anions)/(cations + anions)) was calculated to assess potential analytical errors. The charge balance is 0 when the cations equal the anions. Differences exceeding 5\% suggest an erroneous analysis of a major ionic species or that one of the major ionic species is missing. Charge balances for the analyses shown in Table E-1 range from $-3 \%$ to $+1 \%$, indicating that the analyses are acceptable.

All of the waters are $\mathrm{NaCl}$ in composition with minor $\mathrm{HCO}_{3}$ and $\mathrm{SO}_{4}$. Waters from the Blue Lake and Mosquito Willy's areas display significantly lower salinities than those from the Intrepid Potash, Inc., wells although the measured temperatures of the waters are similar (see Table E-1). Total dissolved solids contents of the Blue Lake waters range from approximately 5000-5500 mg/L, whereas those from the Intrepid Potash, Inc., wells range from $7800-12600 \mathrm{mg} / \mathrm{L}$. The waters of Mosquito Willy's springs have the lowest total dissolved solids, measuring from 4800-4900 mg/L. A Piper Diagram (see Figure E-13) of the geochemical data indicates that waters from the three sample sets (Intrepid wells, Blue Lake, and Mosquito Willy's springs) group together, but there is little separation between groups.

Figure E-13 shows the relationship between $\mathrm{Na}$ and $\mathrm{Cl}$ and it suggests that the well waters from wells IW-6, IW-7, IW-13, and IW-10 could represent mixtures of water from IW-12 and Blue Lake or Mosquito Willy's springs waters.

A significant feature of the Blue Lake waters is their relatively high $\mathrm{Ca} / \mathrm{Mg}$ ratios from 2.9-3.5; Mosquito Willy's springs waters also have high $\mathrm{Ca} / \mathrm{Mg}$ ratios near 2.5. High contents of these cations are typical of carbonate reservoirs. Langmuir (1971) suggested that $\mathrm{Ca} / \mathrm{Mg}$ ratios $>3.0$ indicate interactions with limestones. Ratios between 1.5 and 3.0 can indicate the presence of dolomite beds with a dominantly limestone reservoir whereas ratios $<1.5$ implies interactions with reservoirs consisting mainly of dolomite. Intrepid Potash, Inc., well waters, in contrast have $\mathrm{Ca} / \mathrm{Mg}$ ratios of $<1.5$. The $\mathrm{Ca} / \mathrm{Mg}$ ratios of the Blue Lake waters suggest that the reservoir rocks consist primarily of limestone, whereas the slightly lower $\mathrm{Ca} / \mathrm{Mg}$ ratios of Mosquito Willy's springs waters suggest interaction with limestone with interbedded dolomite. $\mathrm{Ca} / \mathrm{Mg}$ ratios of waters from the Intrepid wells suggest interactions with dolomite.

Figure E-14 shows the K-Na-Mg relationships of the sampled waters. These waters plot near the base of the region of partial equilibration. Giggenbach (1991) suggested that both silica and $\mathrm{K} / \mathrm{Mg}$ geothermometers (Giggenbach, 1991) could be applied to samples plotting in this portion of the diagram, although with caution. Temperatures calculated based on the $\mathrm{K} / \mathrm{Mg}$ geothermometer yield values of $100-112^{\circ} \mathrm{C}$ and are similar for the Intrepid Potash, Inc. and Blue Lake and Mosquito Willy's springs waters. The chalcedony geothermometer, the most appropriate silica geothermometer for low temperature waters, in contrast yields temperatures of $39-63^{\circ} \mathrm{C}$. Although it cannot be demonstrated that mixing with low silica waters has occurred, the low measured temperatures of these waters and the significantly higher temperatures encountered in DBW-3 $\left(88^{\circ} \mathrm{C}\right)$ suggests that dilution is a likely explanation for the low calculated values. 
The anhydrite geothermometer is based on equilibria between the fluid and anhydrite. It is calculated from the $\mathrm{Ca}$ and $\mathrm{SO}_{4}$ contents of the thermal fluids and assumes the presence of anhydrite in the reservoir. Although the presence of anhydrite was not noted on the well logs of nearby wells, gypsum was observed. Anhydrite is a common mineral in carbonate terrains and is likely to be present. Temperatures calculated from the anhydrite geothermometer range from $133-146^{\circ} \mathrm{C}$.

The $\mathrm{Na} / \mathrm{Li}$ geothermometer, although not widely used has been applied with some success to a carbonate reservoir in central Italy (Minissale and Duchi, 1988). The form of the geothermometer used here was derived by Kharaka et al (1982). It yields values similar to those obtained from the anhydrite geothermometer. 
Table E-1. Compositions, measured and geothermometer temperatures of Blue Lake (BL) area, Mosquito Willy's (MW) springs, and Intrepid Potash, Inc. (IW), well waters. Analytical values in mg/L. See Attachment E-1 for laboratory analytical sheet for each sample.

Geothermometer

Temperatures

\begin{tabular}{|c|c|c|c|c|c|c|c|c|c|c|c|c|c|c|c|c|c|c|c|}
\hline \multirow[b]{2}{*}{$\begin{array}{l}\text { Sample } \\
\text { Name } \\
\end{array}$} & \multirow[b]{2}{*}{$\begin{array}{c}\text { Temp } \\
\left({ }^{\circ} \mathrm{C}\right)\end{array}$} & \multirow[b]{2}{*}{$\begin{array}{c}\text { UTM* } \\
\text { East }\end{array}$} & \multirow[b]{2}{*}{$\begin{array}{l}\text { UTM* } \\
\text { North }\end{array}$} & \multirow[b]{2}{*}{ pH } & \multirow[b]{2}{*}{$\mathbf{L i}$} & \multirow[b]{2}{*}{$\mathbf{N a}$} & \multirow[b]{2}{*}{$\mathbf{K}$} & \multirow[b]{2}{*}{$\mathrm{Ca}$} & \multirow[b]{2}{*}{ Mg } & \multirow[b]{2}{*}{$\mathrm{SiO}_{2}$} & \multirow[b]{2}{*}{ Cl } & \multirow[b]{2}{*}{ SO4 } & \multirow[b]{2}{*}{$\mathrm{HCO}_{3}$} & \multirow[b]{2}{*}{$\mathbf{N H}_{4}$} & \multirow[b]{2}{*}{$\mathbf{R b}$} & & & & \\
\hline & & & & & & & & & & & & & & & & $\begin{array}{l}\text { Chal } \\
\left({ }^{\circ} \mathrm{C}\right)\end{array}$ & $\begin{array}{l}\mathrm{K} / \mathrm{Mg} \\
\left({ }^{\circ} \mathrm{C}\right)\end{array}$ & $\begin{array}{c}\text { Anhy } \\
\left({ }^{\circ} \mathrm{C}\right)\end{array}$ & $\begin{array}{c}\mathrm{Na} / \mathbf{L i} \\
\left({ }^{\circ} \mathrm{C}\right)\end{array}$ \\
\hline BL 1 & 29.2 & 750399 & 4487310 & 6.65 & 1.60 & 1640 & 109 & 156 & 49.2 & 25.1 & 2780 & & 313 & 0.200 & 0.537 & 40.6 & 108.1 & 139.2 & 146.6 \\
\hline BL 2 & 28.0 & 751442 & 4487777 & 6.84 & 1.67 & 1720 & 115 & 158 & 54.7 & 26.0 & 2810 & 280 & 311 & $<0.15$ & 0.581 & 41.9 & 108.2 & 137.7 & 146.3 \\
\hline BL 3 & 27.2 & 751350 & 4487676 & 6.97 & 1.63 & 1700 & 120 & 149 & 47.2 & 29.9 & 2840 & 269 & 314 & 0.318 & 0.563 & 48.0 & 111.5 & 139.7 & 145.7 \\
\hline BL 4 & 27.8 & 750292 & 4487504 & 6.95 & 1.59 & 1550 & 107 & 152 & & 27.9 & 2550 & & & & & 45.0 & 109.2 & 139.4 & 149.0 \\
\hline IW 6 & 32.8 & 247849 & 4516657 & 6.87 & 1.57 & 2730 & 126 & 134 & & 38.7 & 4350 & 399 & 203 & & 0.251 & 59.5 & 103.9 & 141.4 & 122.6 \\
\hline IW 7 & 31.3 & 248138 & 4516802 & 6.93 & 1.61 & 2840 & 139 & 143 & 97.9 & 41.3 & 4630 & 384 & 199 & $<0.15$ & 0.266 & 62.5 & 105.3 & 141.7 & 122.0 \\
\hline IW 10 & 25.8 & 248845 & 4517193 & 7.00 & 1.93 & 3690 & 172 & 195 & 142 & 37.0 & 6440 & 460 & 161 & 0.573 & 0.237 & 57.4 & 106.0 & 136.2 & 118.6 \\
\hline IW 12 & 27.3 & 249453 & 4517523 & 7.16 & 2.16 & 4160 & 183 & 253 & 193 & 30.4 & 7100 & 477 & 167 & & & 48.7 & 103.4 & 132.6 & 118.3 \\
\hline IW 13 & 26.8 & 249761 & 4517698 & 7.36 & 1.52 & 2620 & 121 & 141 & 107 & 35.6 & 4300 & 308 & 182 & 0.290 & 0.170 & 55.7 & 100.2 & 145.6 & 123.0 \\
\hline MW N & 26.9 & 752156 & 4484288 & 6.38 & 1.49 & 1400 & 107 & 146 & 58.9 & 24.4 & 2490 & 283 & 306 & $<0.15$ & 0.577 & 39.4 & 105.1 & 135.7 & 150.8 \\
\hline MW S & 26.8 & 752211 & 4484171 & 7.59 & 1.53 & 1460 & 113 & 149 & 59.8 & 27.5 & 2520 & 300 & 305 & $<0.15$ & 0.653 & 44.2 & 106.4 & 134.6 & 150.0 \\
\hline
\end{tabular}

* Blue Lake locations in UTM Zone 11; Intrepid Potash, Inc. well locations in UTM Zone 12. The following constituents were below detection (see Attachment E-1 for analytical values): As $=<0.01 ; \mathrm{Cs}=<0.1 ;$ Carbonate Alkalinity (as $\mathrm{HCO} 3-)=<2 ; \mathrm{NH} 4=<0.15$. Geothermometer abbreviations: Chal $=$ chalcedony; Anhy $=$ anhydrite 


\section{Conclusions}

Thermal waters were sampled from springs and thermally fed ponds in the Blue Lake thermal area, Mosquito Willy's springs, and from Intrepid Potash, Inc., wells to the north. Temperatures of the thermal waters range from $26-33^{\circ} \mathrm{C}$. The well waters have salinities exceeding $8000 \mathrm{mg} / \mathrm{L}$ and are interpreted to reflect mixing of lower salinity water, perhaps similar to the Blue Lake area waters and waters that have interacted with salt deposits. Mosquito Willy's Springs waters have salinities below $5000 \mathrm{mg} / \mathrm{L}$; the Blue Lake waters have salinities of about 5000-5500 mg/L. $\mathrm{Ca} / \mathrm{Mg}$ ratios of the Blue Lake and Mosquito Willy's Springs waters are between 2.5 and 3.5 and suggest the waters have flowed through limestone or limestone interbedded with dolomite. Geothermometer temperatures calculated from analyses of the sampled waters suggest possible reservoir temperatures are in the range of $110-150^{\circ} \mathrm{C}$.

Thermal waters were sampled from springs and thermally fed ponds in the Blue Lake thermal area and from Intrepid Potash Inc. wells to the north. Temperatures of the thermal waters range from $27-31^{\circ} \mathrm{C}$. The well waters have salinities exceeding $8000 \mathrm{mg} / \mathrm{L}$ and are interpreted to reflect mixing of lower salinity water, perhaps similar to the Blue Lake area waters and waters that have interacted with salt deposits. The Blue Lake waters have salinities of about 5000 $5500 \mathrm{mg} / \mathrm{L}$. Ca/Mg ratios of the Blue Lake waters are close to 3 and suggest the waters have flowed through limestones interbedded with dolomite. Geothermometer temperatures calculated from the Blue Lake water analyses suggest possible reservoir temperatures are in the range of $110-140^{\circ} \mathrm{C}$.

\section{References}

Fournier, R. O., 1981, Application of water geochemistry to geothermal exploration and reservoir engineering in Geothermal Systems: Principles and Case Histories, Ryback and Muffler eds., John Wiley and Sons, NY, p. 109-143.

Kharaka, Y.K., Lico, M.S., and Law, L.M., 1982. Chemical geothermometers applied to formation waters, Gulf of Mexico and California basins: American Association of Petreoleum Geologists Bulletin, v. 66, p. 588.

Giggenbach, W.F., 1991, Chemical techniques in geothermal exploration in UNITAR/UNDP Guidebook: Application of geochemistry in resources development, p. 119-144.

Langmuir, D., 1971, The geochemistry of some carbonate groundwaters in central Pennsylvania. Geochemica et Cosmochimica Acta, v. 35, p. 1023-1045.

Minissale, A.A. and Duchi, V., 1988, Geothermometry on fluids circulating in a carbonate reservoir in north-central Italy. Journal of Volcanology and Geothermal Research, v. 35, p. 237-252. 


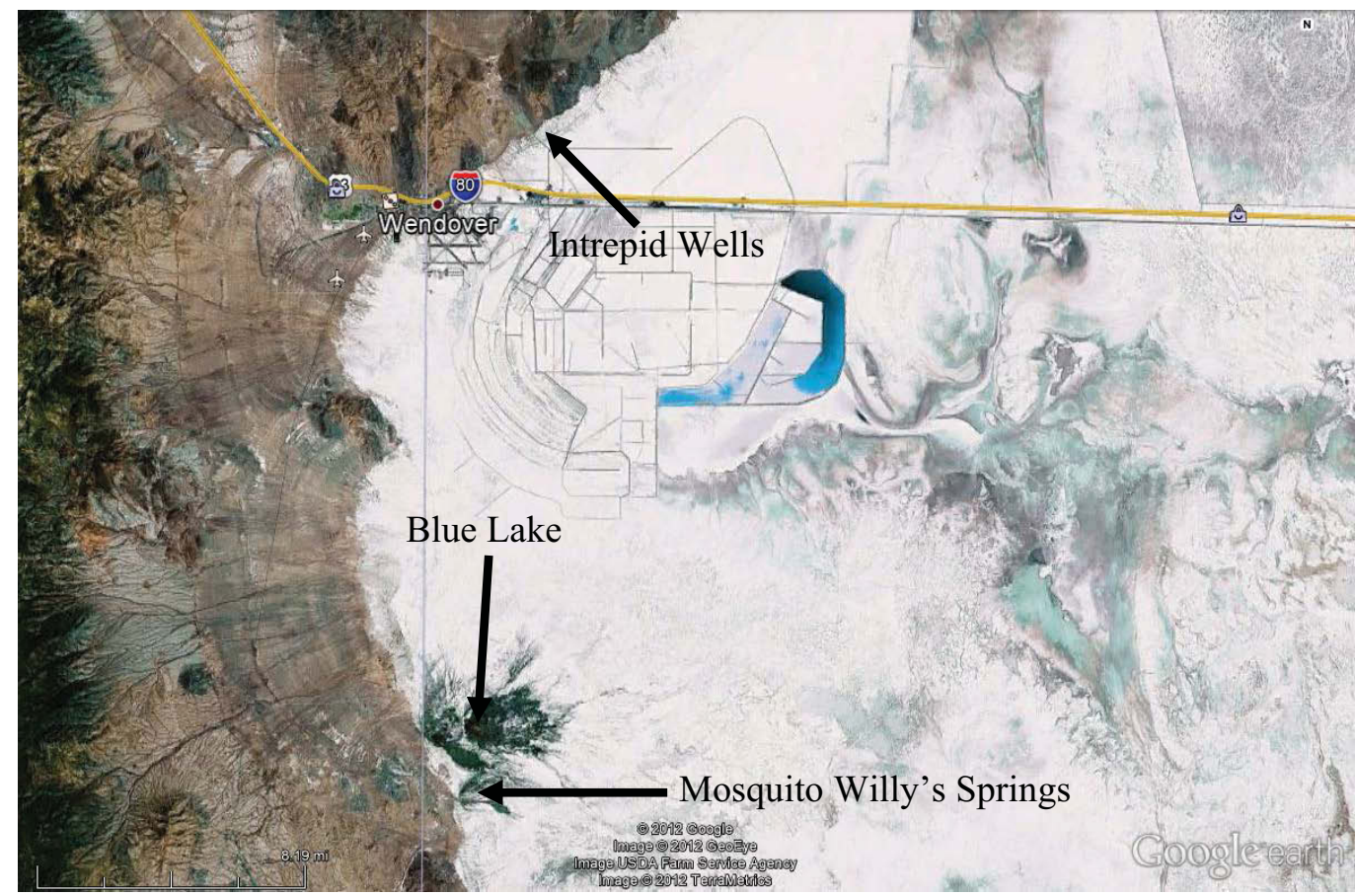

Figure E-1. Satellite image indicating the locations of the Intrepid, Blue Lake, and Mosquito Willy's sampling areas.

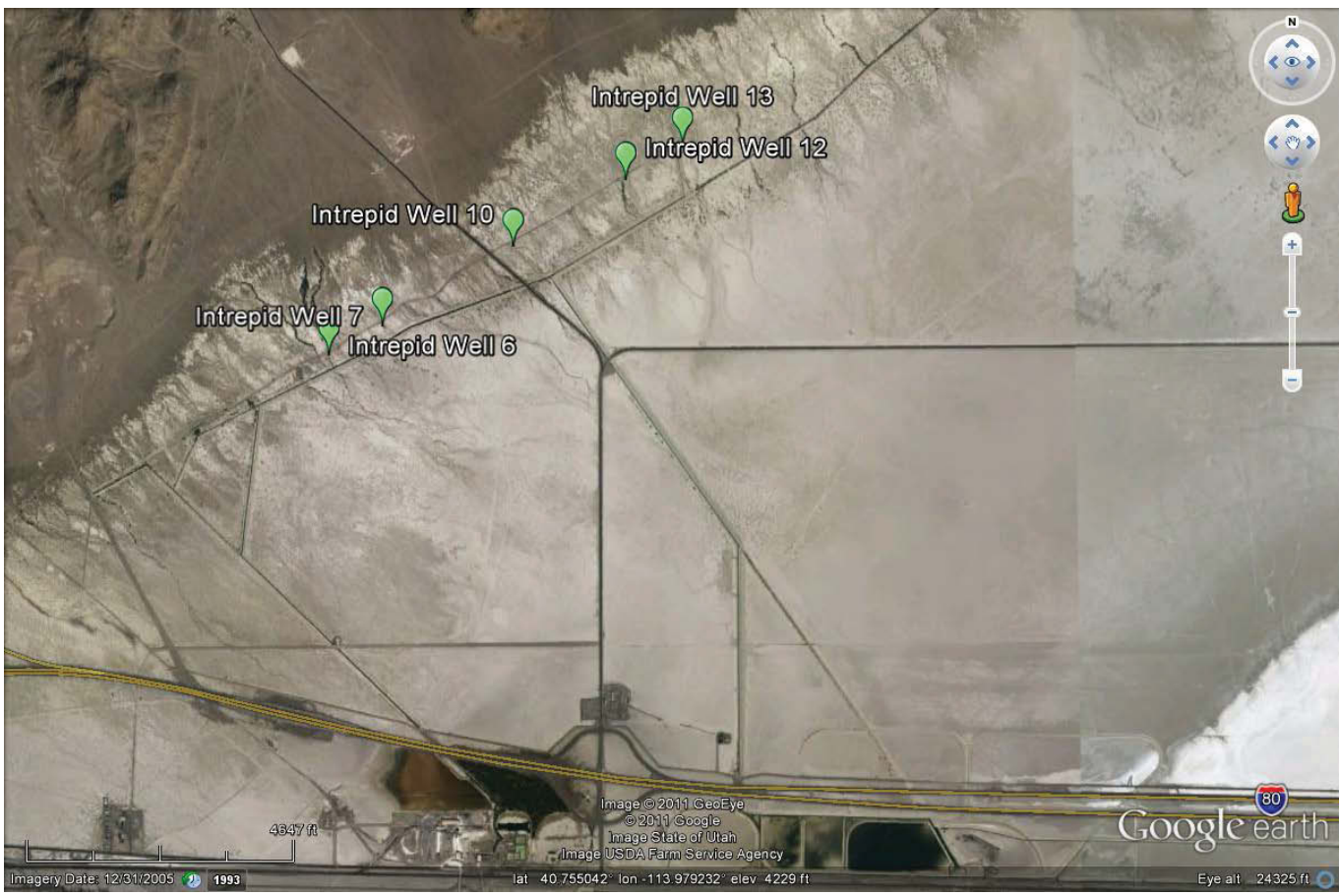

Figure E-2. Water samples were collected from wells IW-6, IW-7, IW-10, IW-12, and IW-13, located adjacent to the southeast flank of the Silver Island Mountains. 


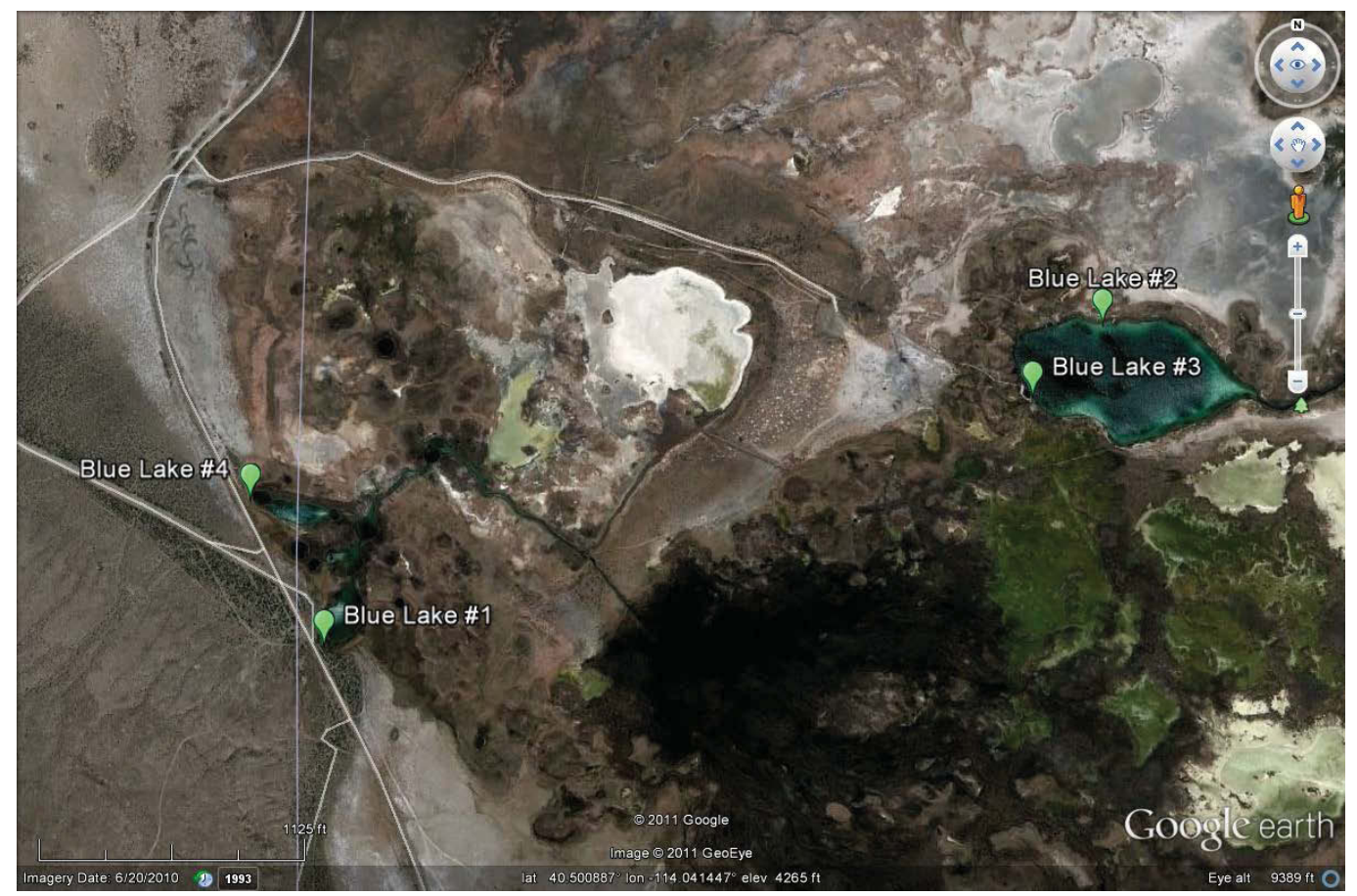

Figure E-3. Satellite image of the Blue Lake area showing the locations of the four samples collected for chemical analyses.

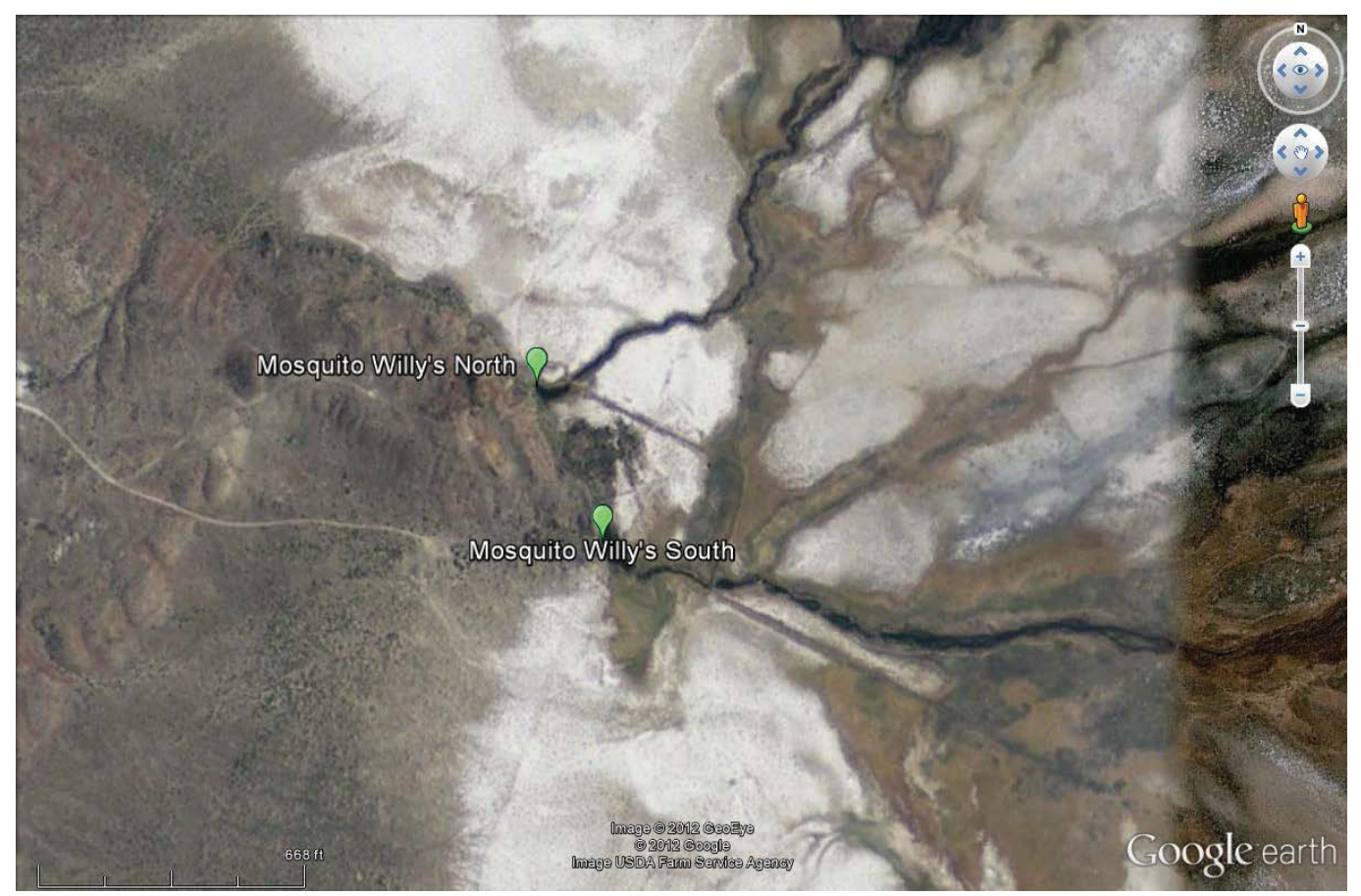

Figure E-4. Satellite image of Mosquito Willy's springs showing north and south sample locations. 


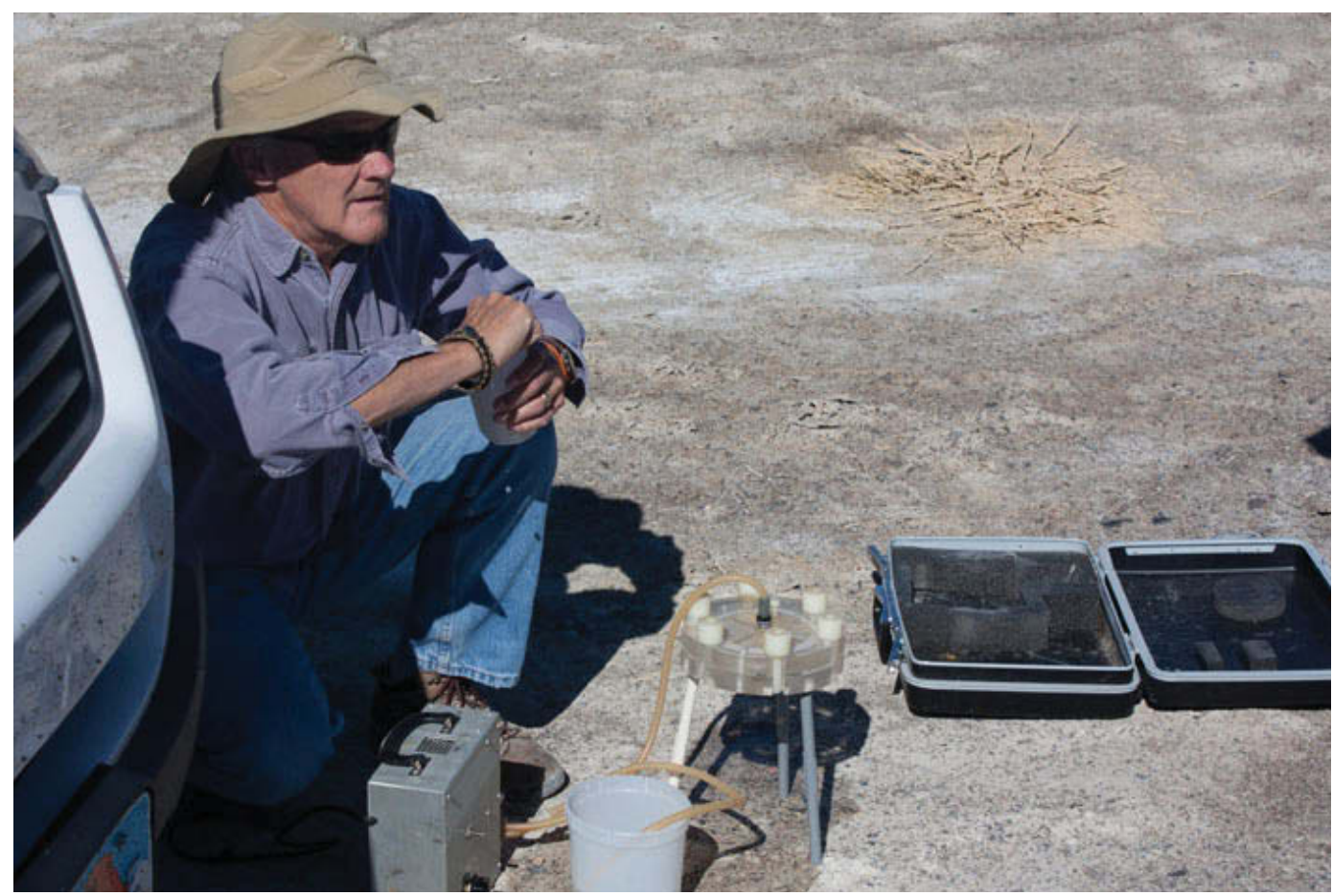

Figure E-5. Sampling procedures included filtering of some samples.

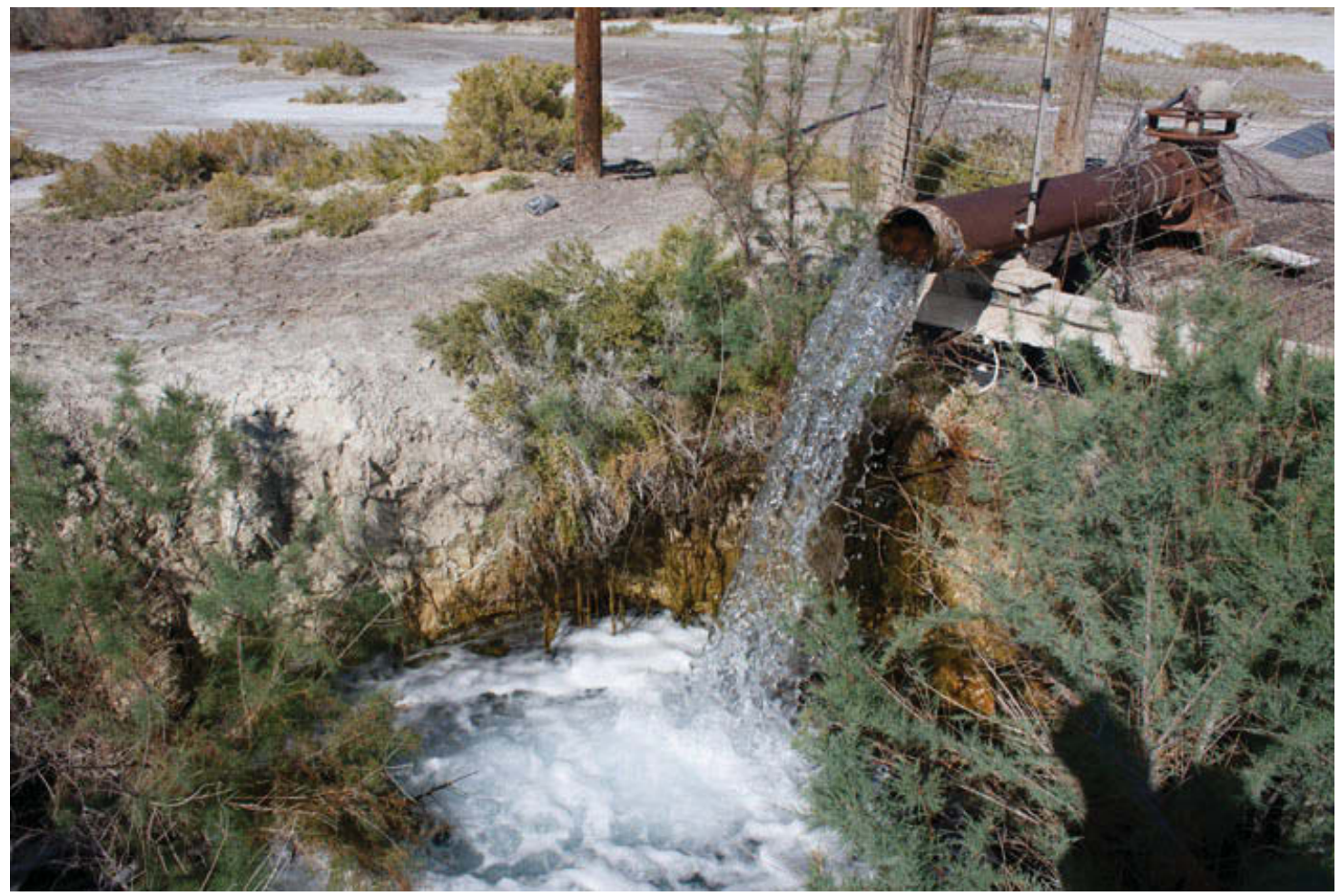

Figure E-6. Sample location IW-6. 


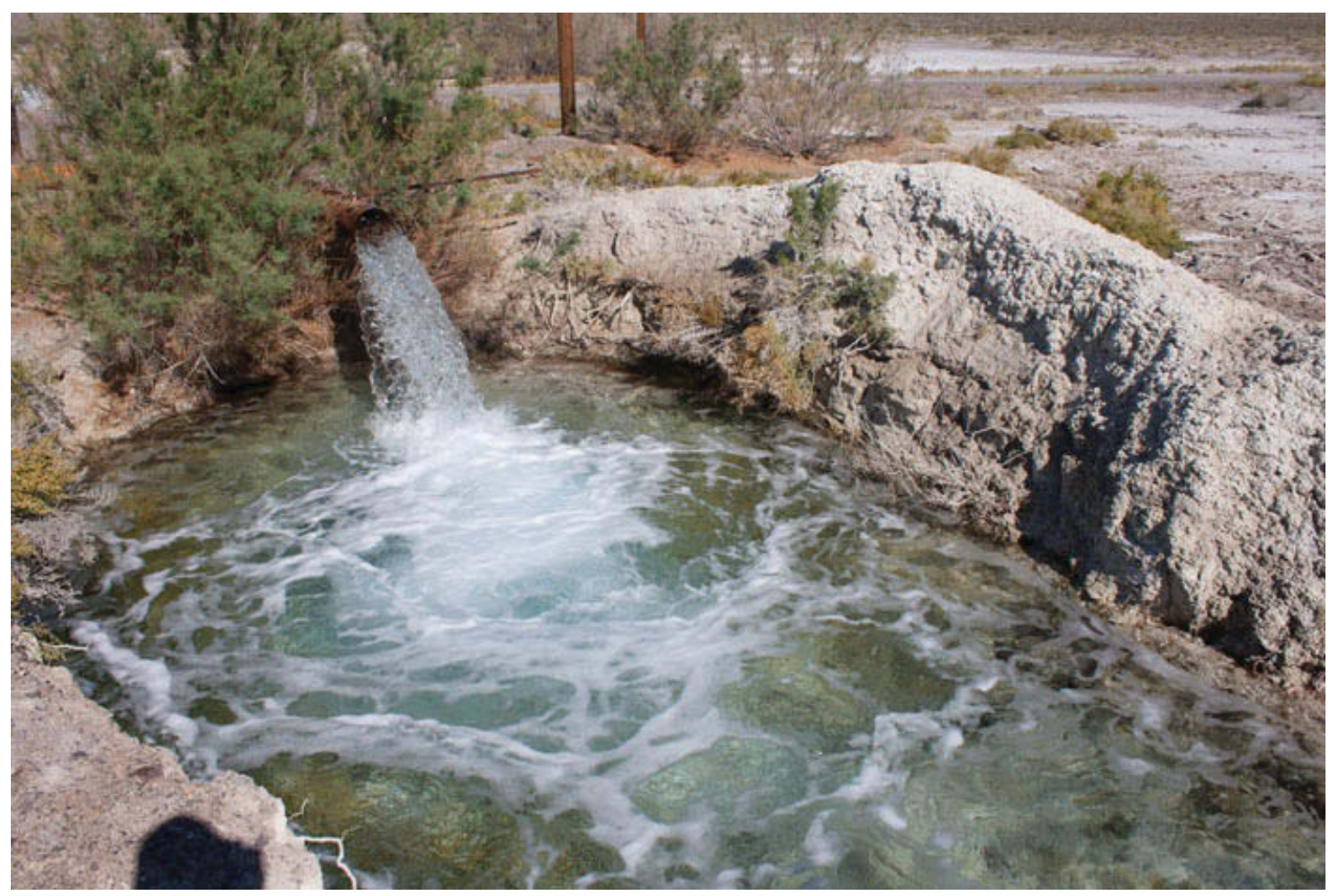

Figure E-7. Sample location IW-7.

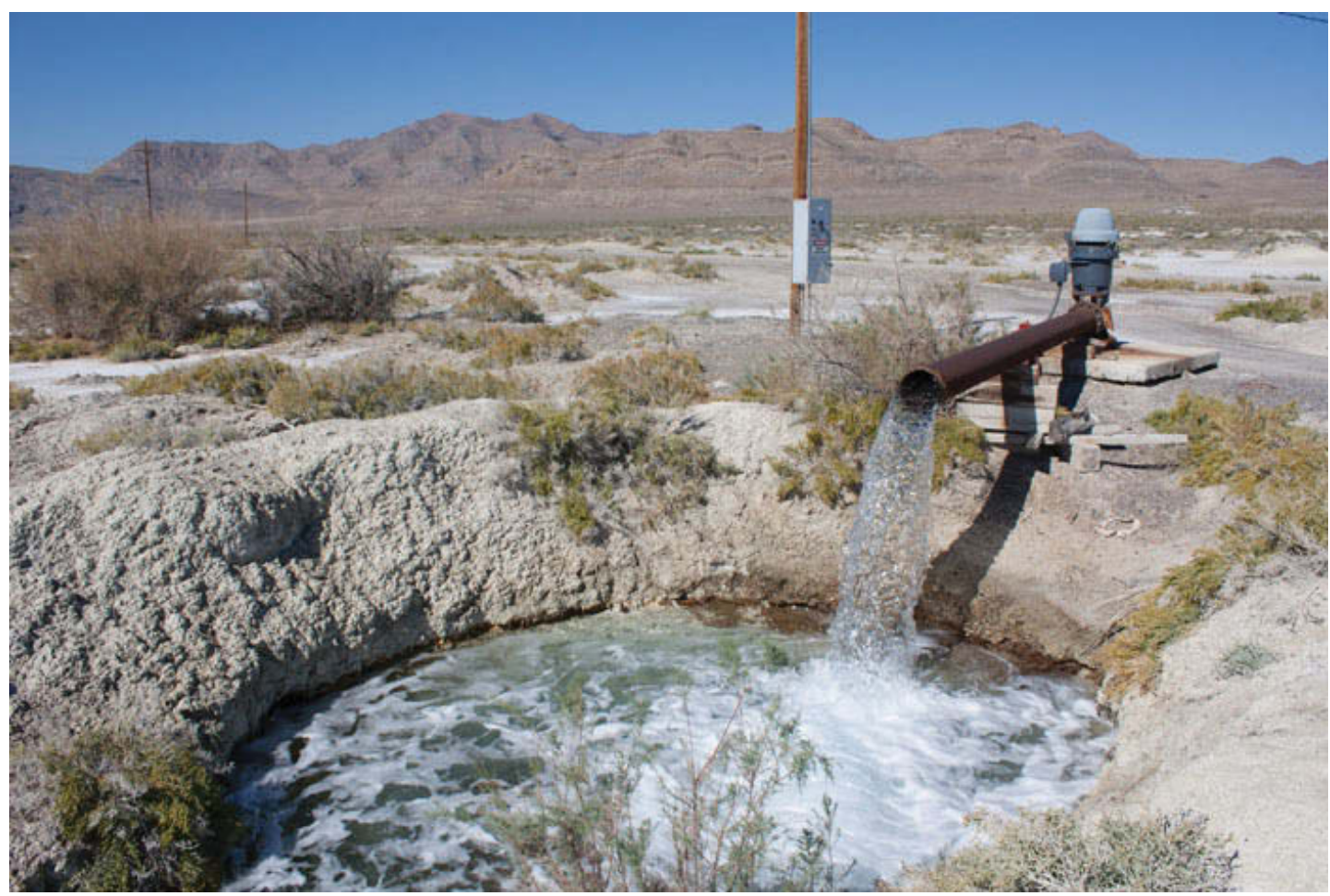

Figure E-8. Sample location IW-10. 


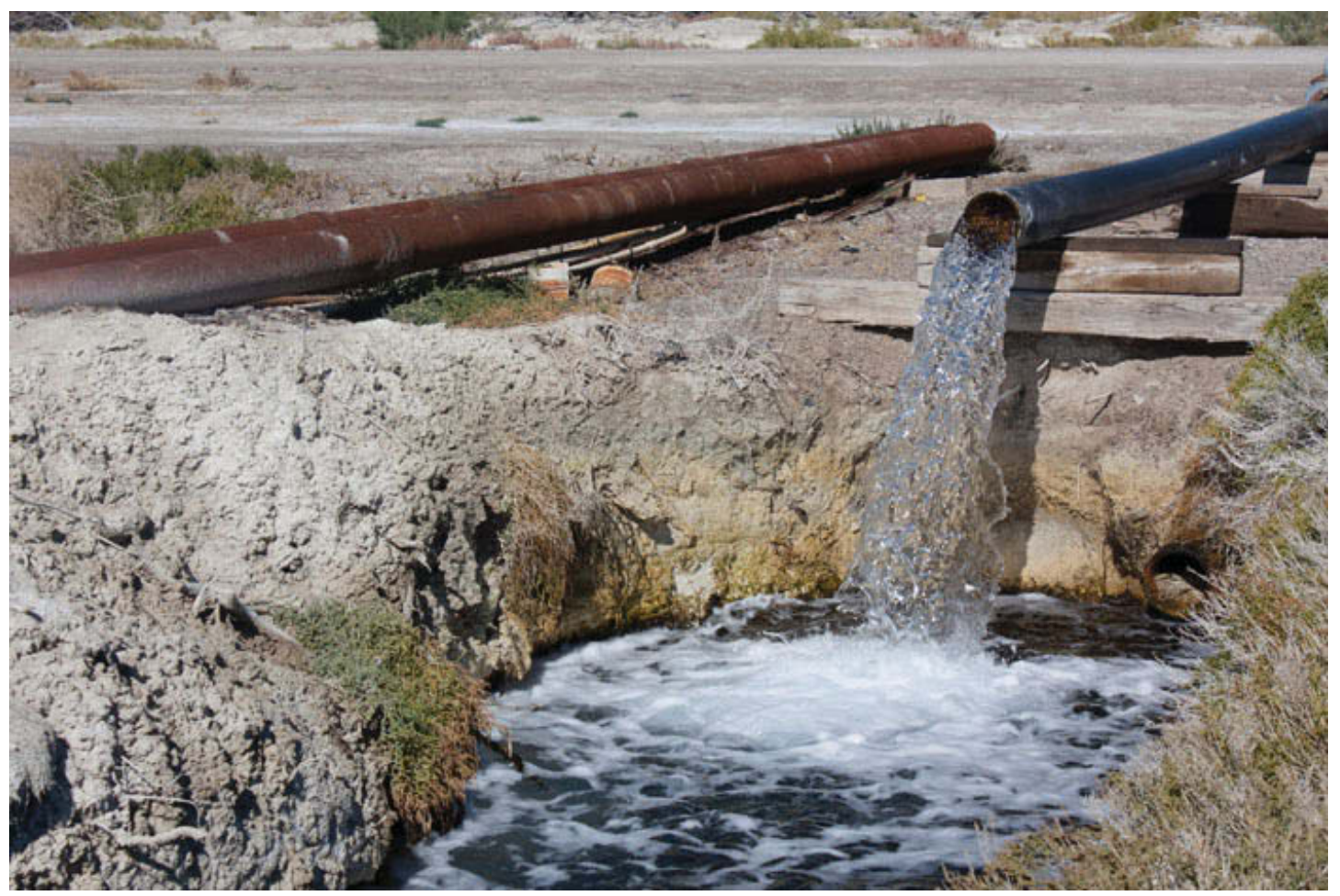

Figure E-9. Sample location IW-12.

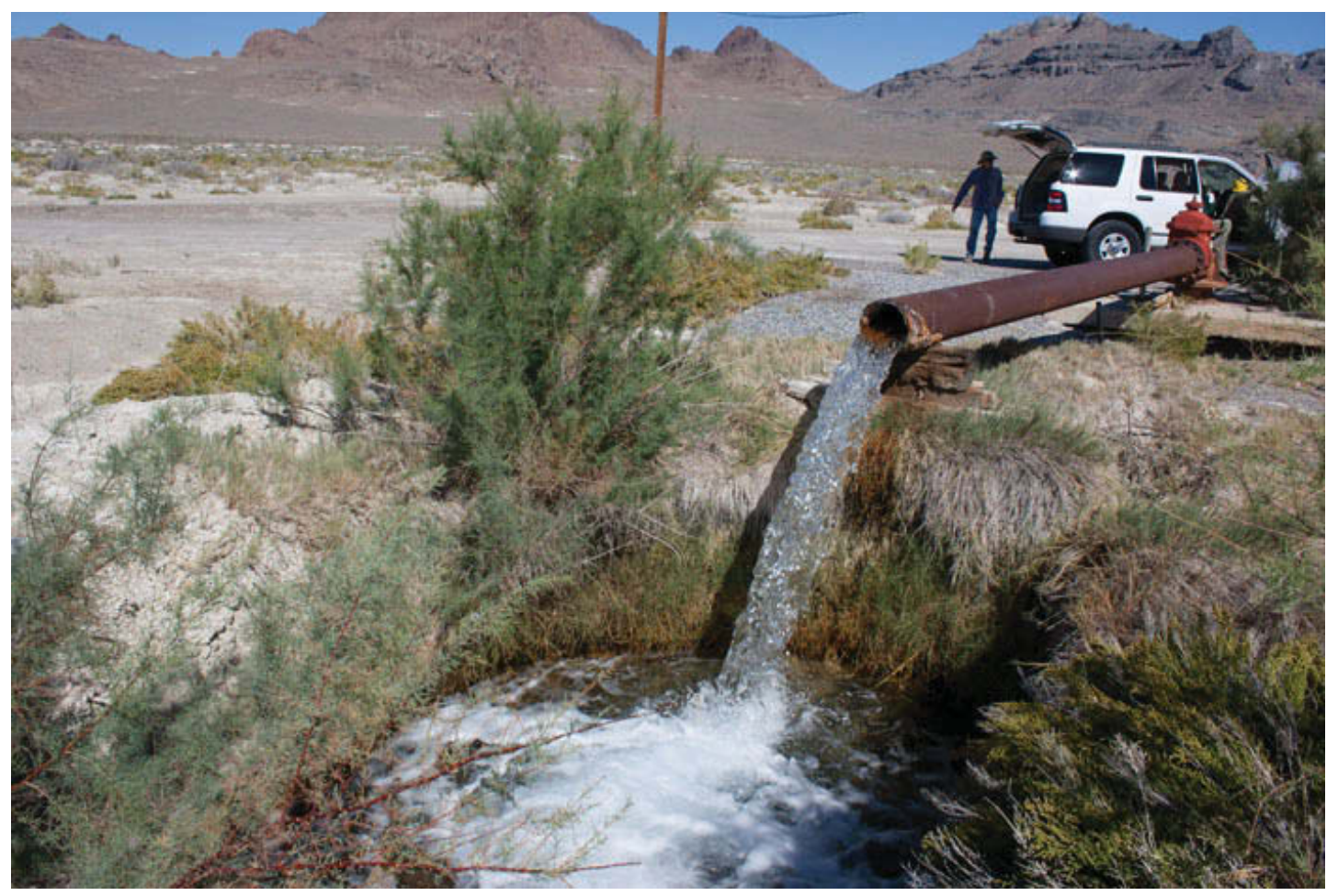

Figure E-10. Sample location IW-13. 


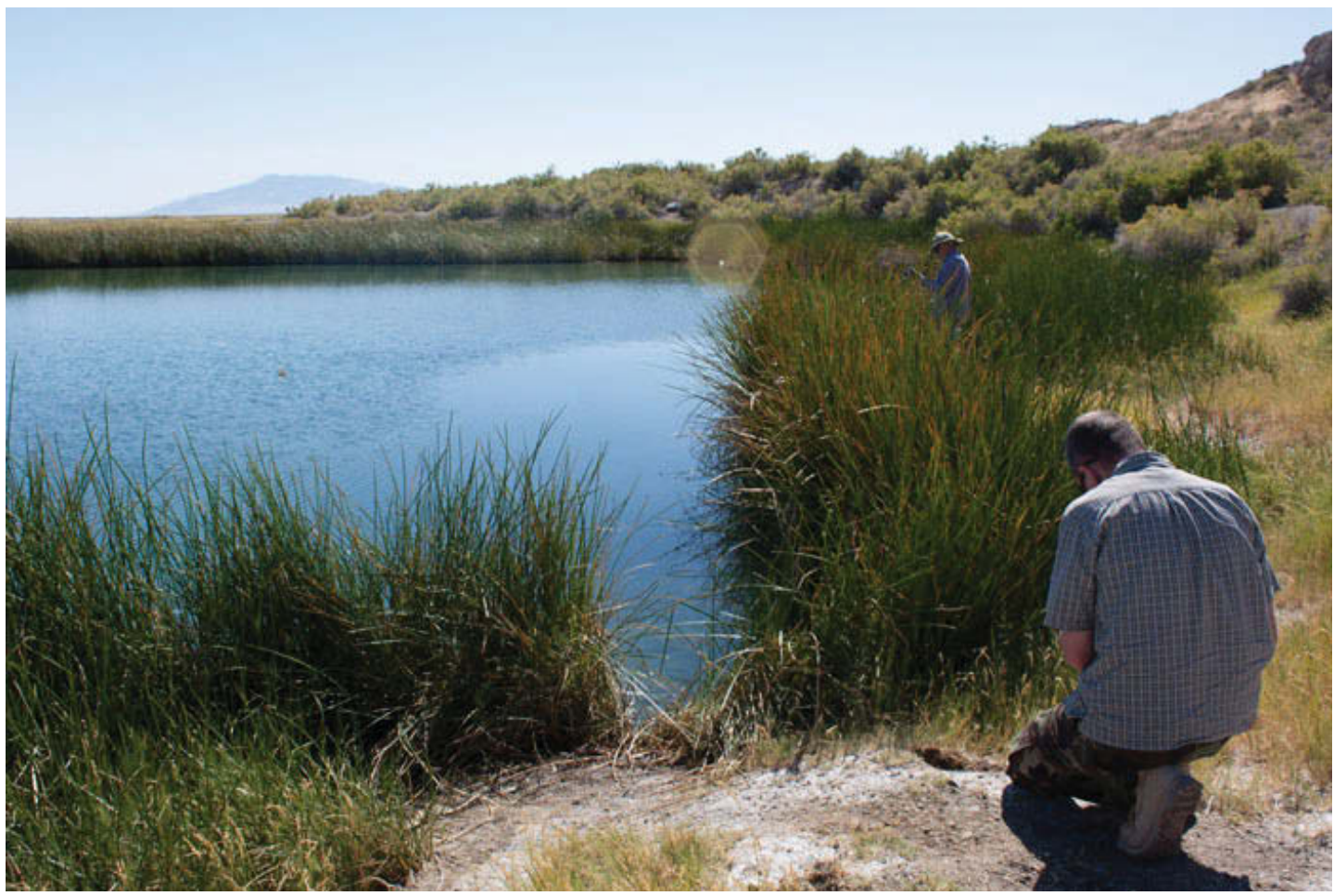

Figure E-11. Near sample location BL\#1. The sample was collected from a spring flowing into the pond, located by the figure standing in the tall grass on the right side of the image.

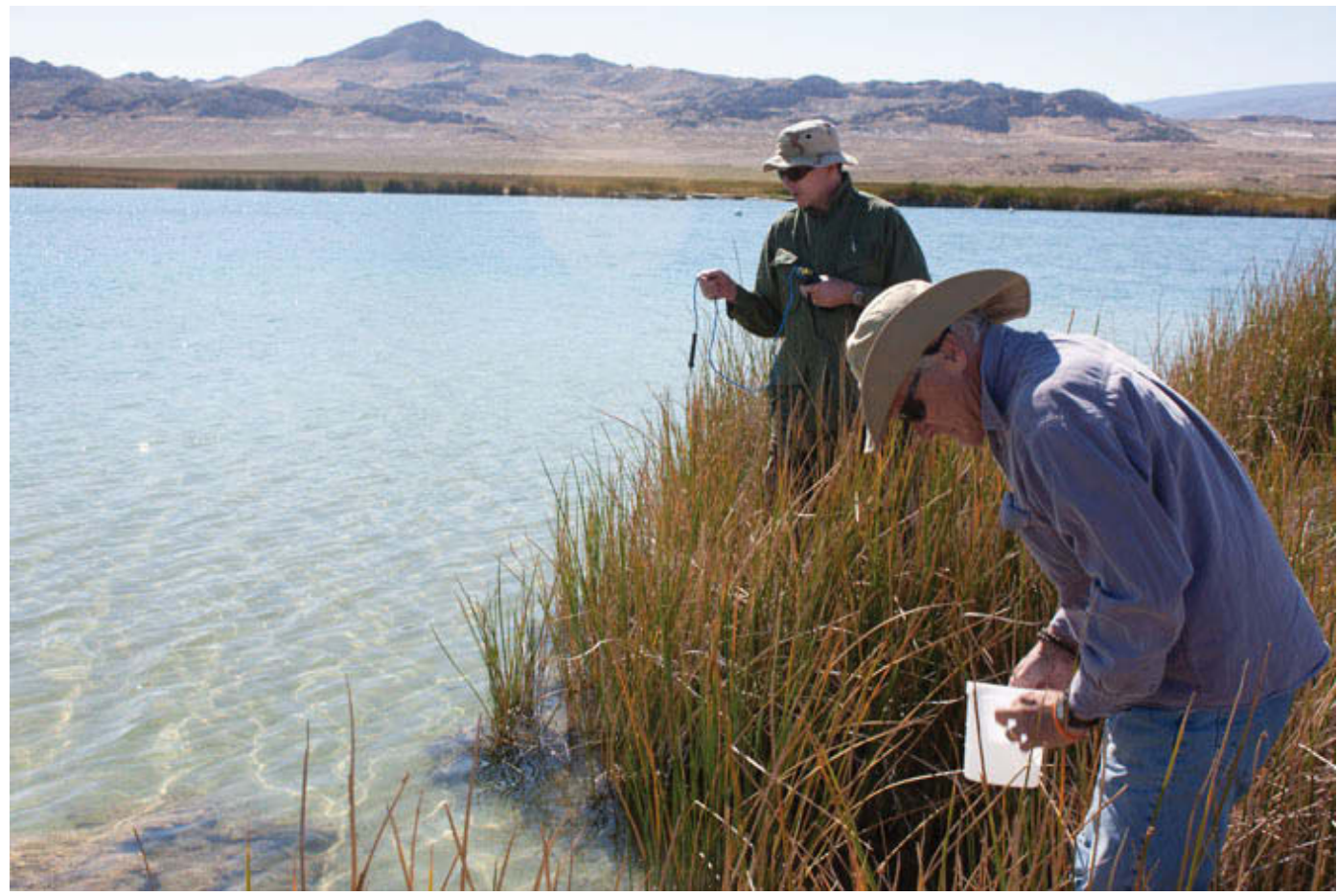

Figure E-12. Sample location BL\#2. 


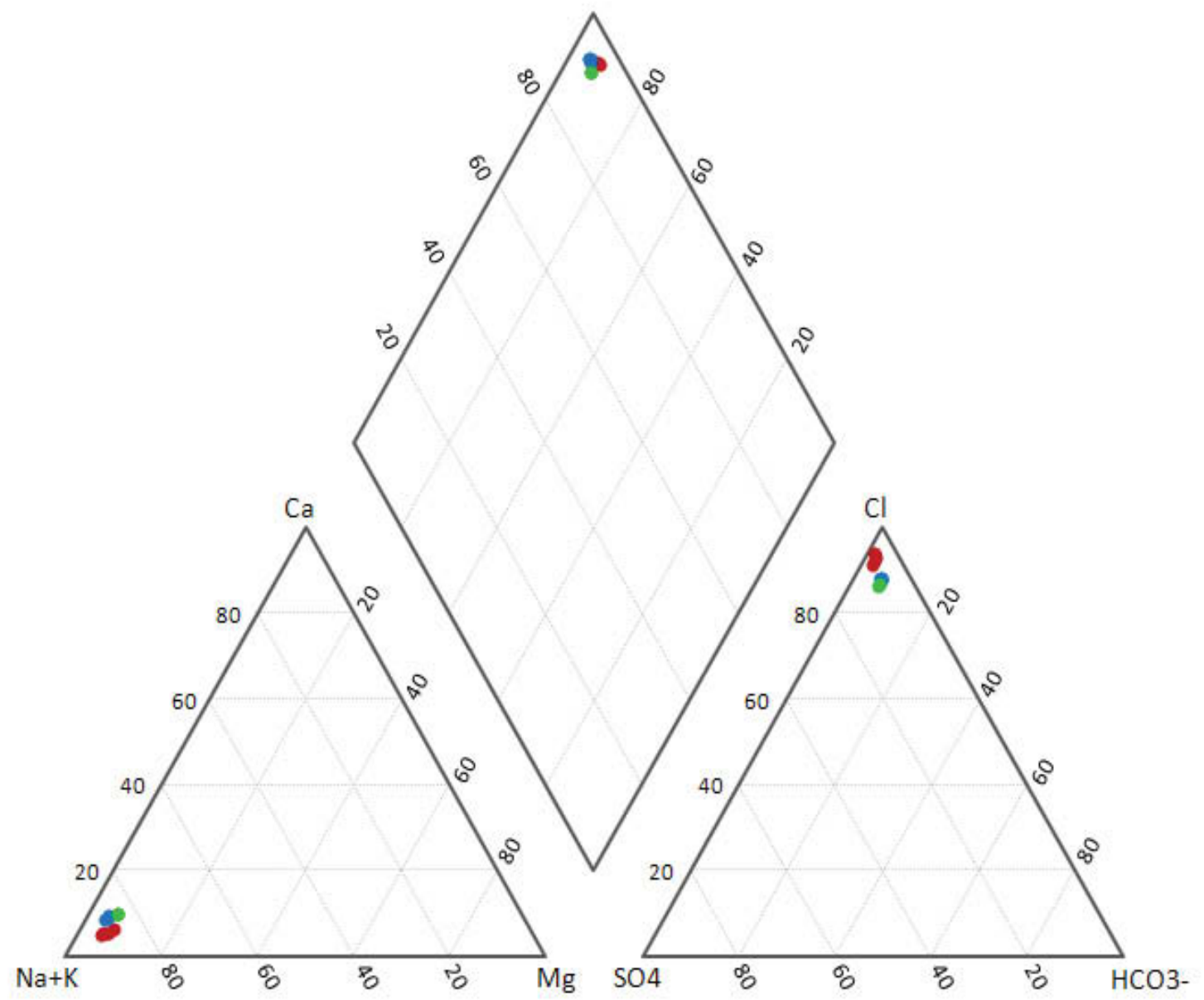

Figure E-13. Piper diagram of ions (\%meq/l) in waters from Intrepid wells (red), Blue Lake (blue), and Mosquito Willy's Springs (green). The diagram shows that samples from the various sets group together but there is little separation between groups. 


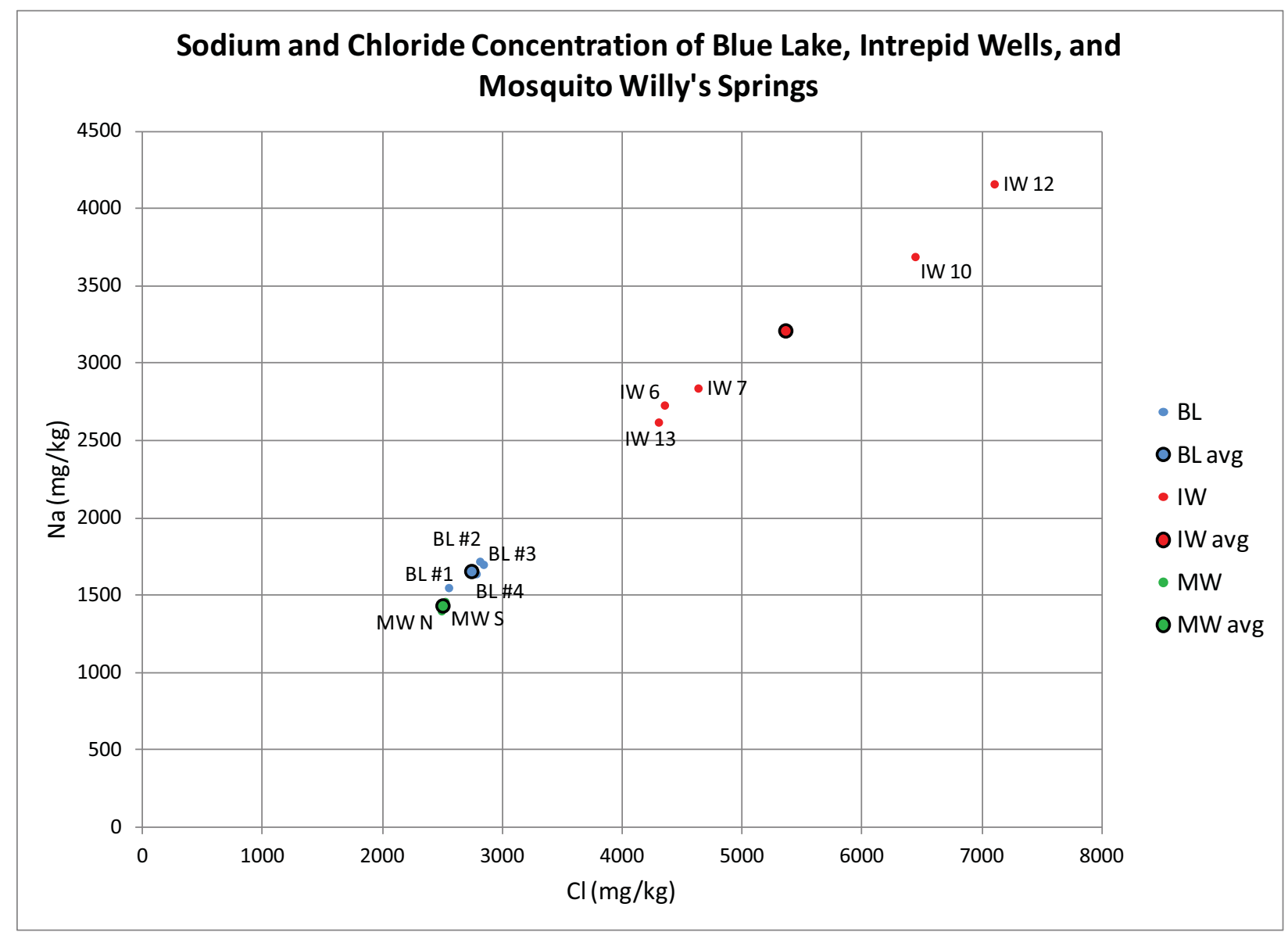

Figure E-14. Relationship between $\mathrm{Na}$ and $\mathrm{Cl}$ in the Blue Lake (BL), Intrepid Potash, Inc., wells (IW) and Mosquito Willy's (MW) springs. Waters from the Intrepid Potash Inc. wells IW-6, IW-7, IW-13, and IW-10 could represent mixtures of water from IW-12 and Blue Lake waters. 


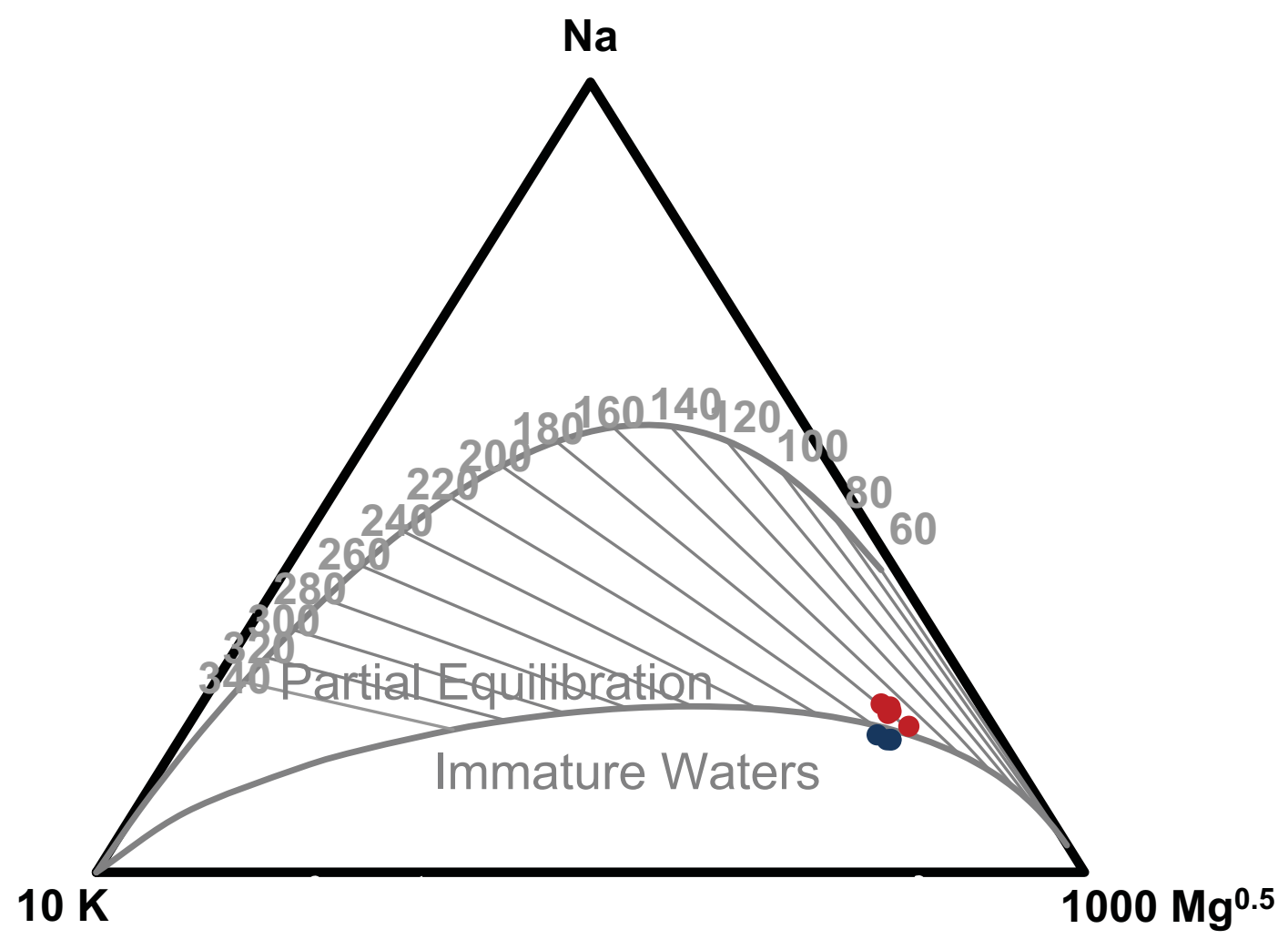

Figure E-15. K-Na-Mg plot of Blue Lake area waters. Blue Lake samples are shown in blue; Intrepid well samples are shown in red; Mosquito Willy's samples are shown in green. The samples group at the lower boundary of the region where partial equilibration with the rock is expected. 
This page intentionally left blank. 